\title{
Cost-Benefit Considerations in Regulatory Analysis
}

Manuscript Completed: September 1995

Date Published: October 1995

Prepared by

V. Mubayi, V. Sailor, ${ }^{1}$ G. Anandalingam ${ }^{2}$

Brookhaven National Laboratory

Upton, NY 11973-5000

R. Woods, NRC Project Manager

Prepared for

Division of Systems Technology

Office of Nuclear Regulatory Research

U.S. Nuclear Regulatory Commission

Washington, DC 20555-0001

NRC Job Code L1636

${ }^{1} \mathrm{BNL}$ Consultant

${ }^{2}$ University of Pennsylvania, Department of Systems Engineering

Philadelphia, PA 


\section{DISCLAIMER}

This report was prepared as an account of work sponsored by an agency of the United States Government. Neither the United States Government nor any agency thereof, nor any of their employees, make any warranty, express or implied, or assumes any legal liability or responsibility for the accuracy, completeness, or usefulness of any information, apparatus, product, or process disclosed, or represents that its use would not infringe privately owned rights. Reference herein to any specific commercial product, process, or service by trade name, trademark, manufacturer, or otherwise does not necessarily constitute or imply its endorsement, recommendation, or favoring by the United States Government or any agency thereof. The views and opinions of authors expressed herein do not necessarily state or reflect those of the United States Government or any agency thereof. 


\section{DISCLAIMER}

Portions of this document may be illegible in electronic image products. Images are produced from the best available original document. 


\begin{abstract}
Justification for safety enhancements at nuclear facilities, e.g., a compulsory backfit to nuclear power plants, requires a value-impact analysis of the increase in overall public protection versus the cost of implementation. It has been customary to assess the benefits in terms of radiation dose to the public averted by the introduction of the safety enhancement. Comparison of such benefits with the costs of the enhancement then requires an estimate of the monetary value of averted dose (dollars/person rem). This report reviews available information on a variety of factors that affect this valuation and assesses the continuing validity of the figure of $\$ 1000$ /person-rem averted, which has been widely used as a guideline in performing value-impact analyses. Factors that bear on this valuation include the health risks of radiation doses, especially the higher risk estimates of the BEIR V committee, recent calculations of doses and offsite costs by consequence codes for hypothesized severe accidents at U.S. nuclear power plants under the NUREG-1150 program, and recent information on the economic consequences of the Chernobyl accident in the Soviet Union and estimates of risk avoidance based on the willingness-to-pay criterion. The report analyzes these factors and presents results on the dollars/person-rem ratio arising from different assumptions on the values of these factors.
\end{abstract}




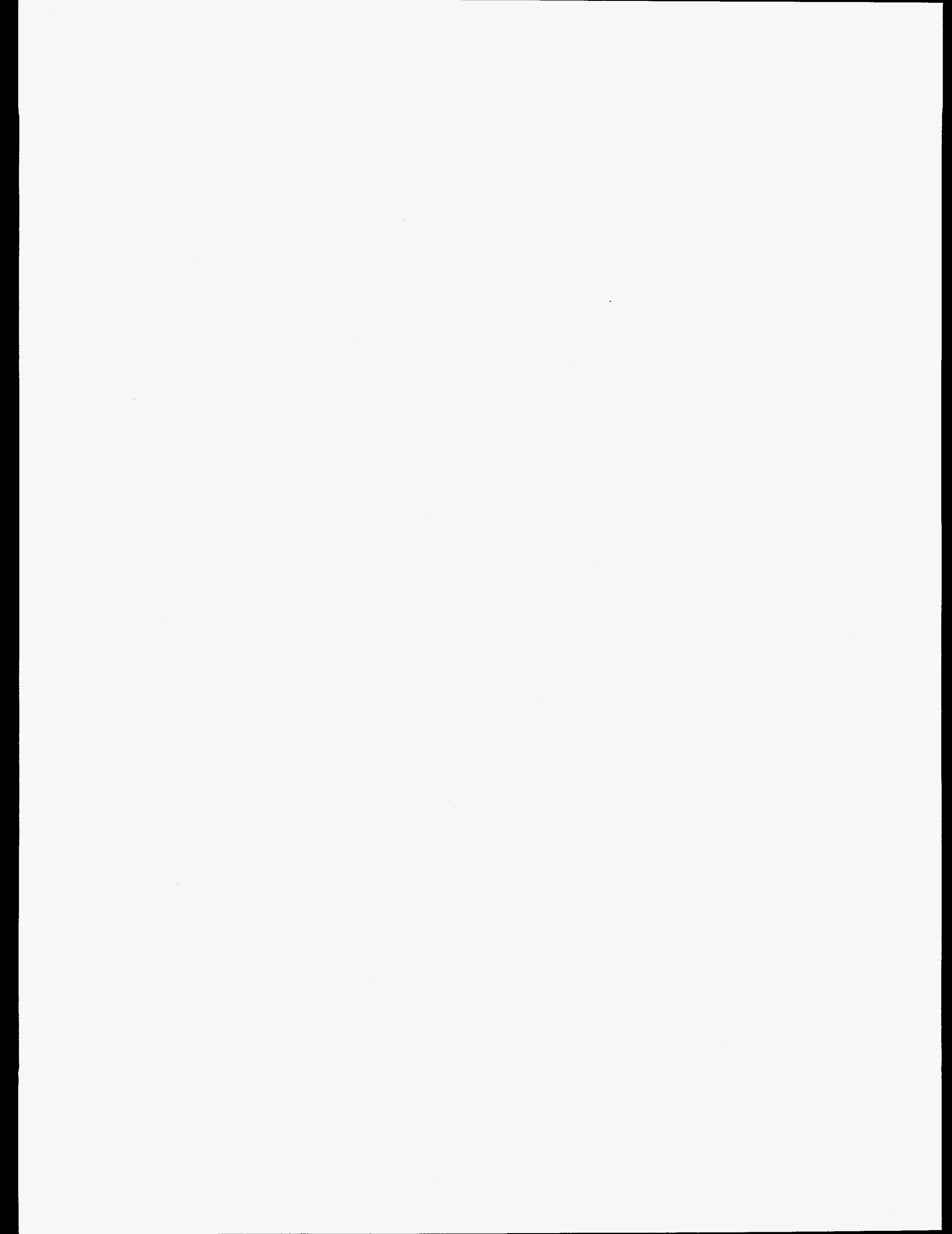




\section{TABLE OF CONTENTS}

Page

Abstract

iii

Acknowledgements $\ldots \ldots \ldots \ldots \ldots \ldots \ldots \ldots \ldots \ldots \ldots \ldots \ldots \ldots \ldots \ldots \ldots \ldots \ldots \ldots \ldots$

1.0 Introduction: Value-Impact Considerations in Radiation Protection $\ldots \ldots \ldots \ldots \ldots \ldots \ldots$

1.1 Regulatory Requirements (The "Backfit Rules") $\ldots \ldots \ldots \ldots \ldots \ldots \ldots \ldots \ldots \ldots \ldots$ 1-1

1.2 Averted Radiation Dose as a Surrogate for Enhanced Public Health and Safety ....... 1-2

1.3 The Monetary Worth of Avoided Doses $\ldots \ldots \ldots \ldots \ldots \ldots \ldots \ldots \ldots \ldots \ldots \ldots \ldots$

1.3.1 Background and History of the NRC $\$ 1000$ Per Person-Rem Valuation $\ldots \ldots \ldots \quad 1-3$

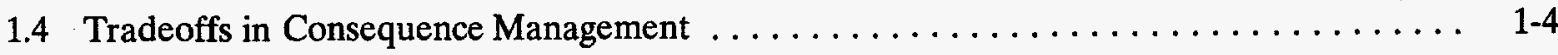

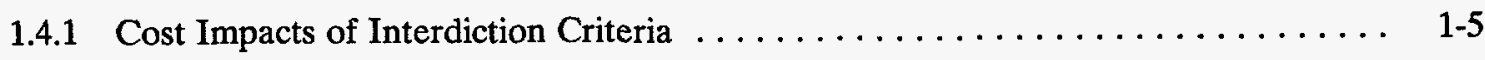

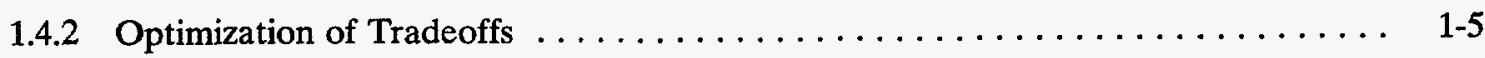

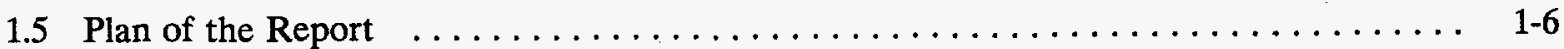

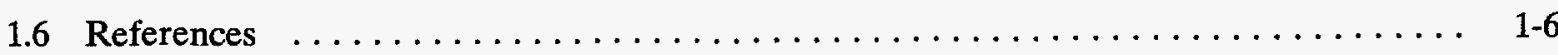

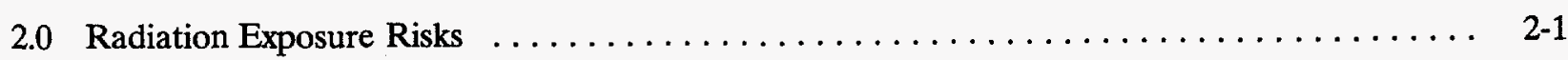

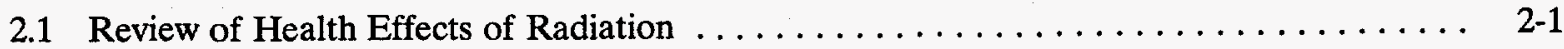

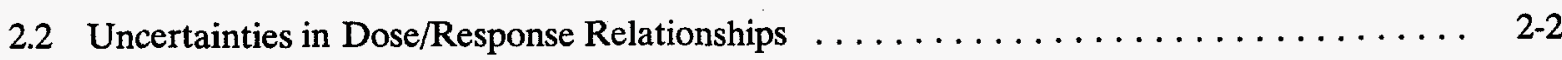

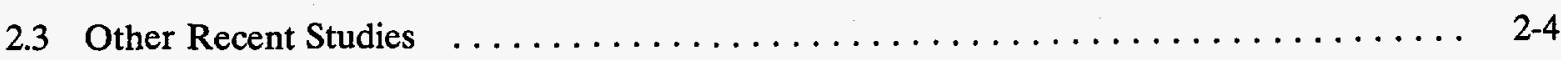

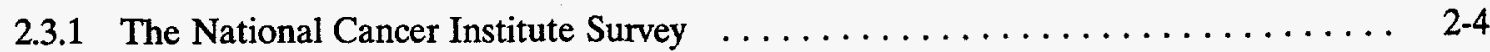

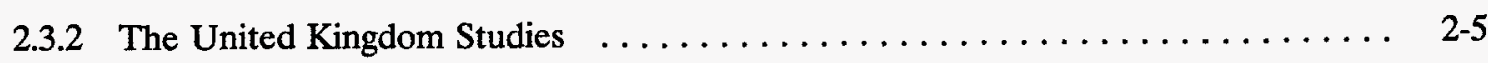

2.4 Risks of Latent Health Effect from Low-LET, Low Dose Rate Radiation Doses . . . . . 2-6

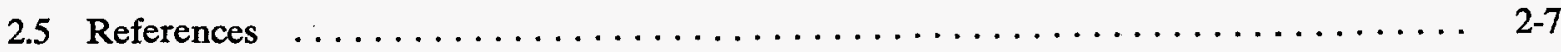

3.0 The Monetary Costs of Latent Health Effects $\ldots \ldots \ldots \ldots \ldots \ldots \ldots \ldots \ldots \ldots \ldots \ldots \ldots$

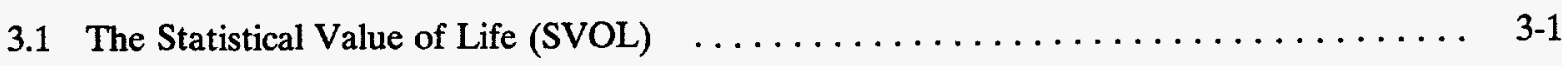

3.2 The "Human Capital" Approach to the SVOL $\ldots \ldots \ldots \ldots \ldots \ldots \ldots \ldots \ldots \ldots \ldots \ldots \ldots$

3.2.1 Estimates of the Value of Averted Dose Using the Human Capital Approach $\ldots$ 3-2

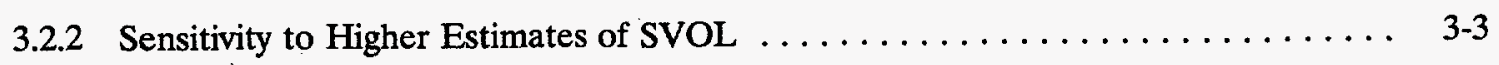

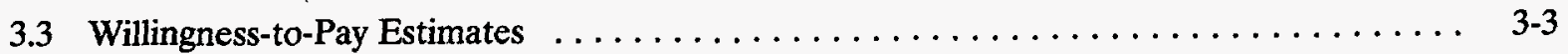

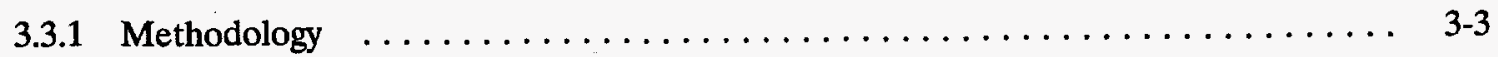

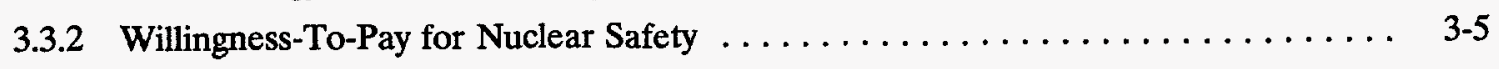

3.3.3 WTP for Reducing Public Exposure Risk $\ldots \ldots \ldots \ldots \ldots \ldots \ldots \ldots \ldots \ldots$ 


\section{TABLE OF CONTENTS (continued)}

Page

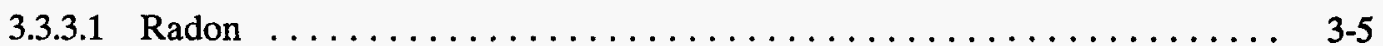

3.3.3.2 Other Radiation Related Studies $\ldots \ldots \ldots \ldots \ldots \ldots \ldots \ldots \ldots$ 3-7

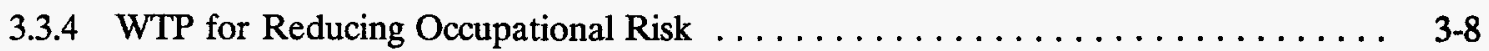

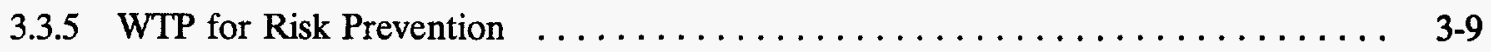

3.3.6 Summary of SVOL based on WTP $\ldots \ldots \ldots \ldots \ldots \ldots \ldots \ldots \ldots \ldots \ldots \ldots \ldots$

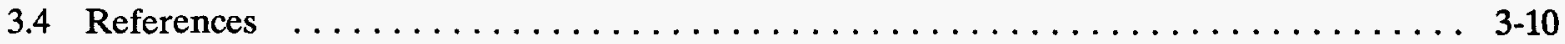

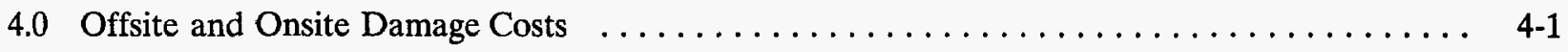

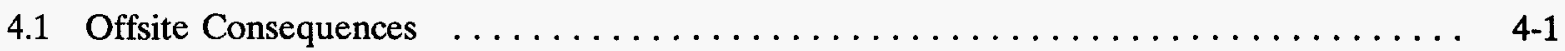

4.1.1 Offsite Consequences Estimated in the NUREG-1150 Studies $\ldots \ldots \ldots \ldots \ldots$ 4-2

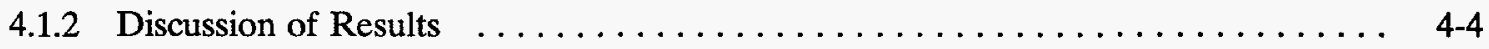

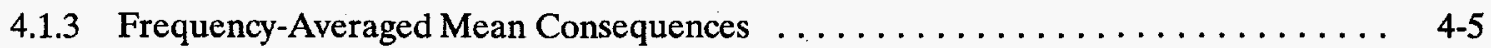

4.1.4 Variation of Offsite Costs and Doses with the Long-Term Interdiction Limit ... . 4-6

4.1.5 Total Costs as a Function of Long-Term Interdiction Limit $\ldots \ldots \ldots \ldots \ldots \ldots$ 4-7

4.2 Onsite Damage Costs $\ldots \ldots \ldots \ldots \ldots \ldots \ldots \ldots \ldots \ldots \ldots \ldots \ldots \ldots \ldots$

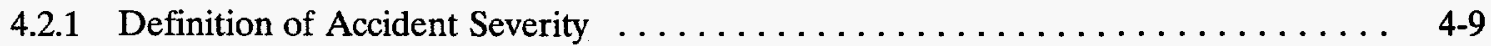

4.2.2 Review of Onsite Damage Cost Estimates $\ldots \ldots \ldots \ldots \ldots \ldots \ldots \ldots \ldots \ldots \ldots \ldots$

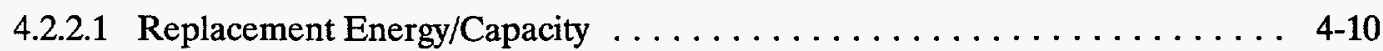

4.2.2.2 Cleanup and Decontamination Costs $\ldots \ldots \ldots \ldots \ldots \ldots \ldots \ldots$ 4-12

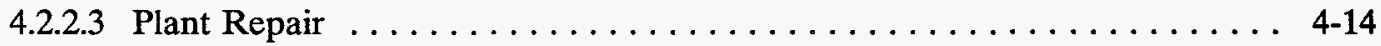

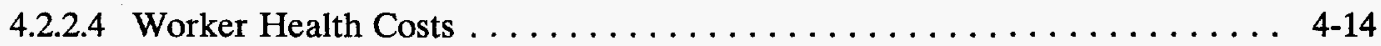

4.2.2.5 Total Onsite Costs of Severe Accidents . . . . . . . . . . . 4-14

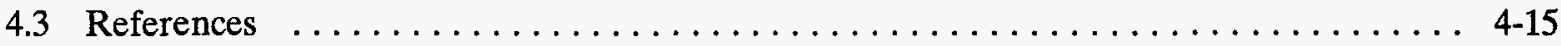

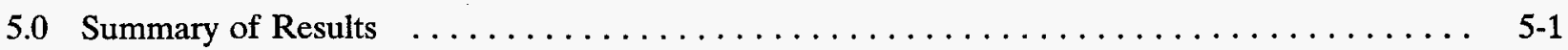

Appendix A Consequences of the Chernobyl Accident $\ldots \ldots \ldots \ldots \ldots \ldots \ldots \ldots \ldots \ldots$ A-1 


\section{LIST OF FIGURES}

Figure

Page

1-1 Cost as a Function of the Interdiction Level $\ldots \ldots \ldots \ldots \ldots \ldots \ldots \ldots \ldots$

4-1 Frequency-Averaged Conditional Consequences at 50 Miles as a Function of Interdiction Limit, Grand Gulf $\ldots \ldots \ldots \ldots \ldots \ldots \ldots \ldots \ldots \ldots \ldots \ldots \ldots \ldots \ldots \ldots \ldots \ldots$

4-2 Frequency-Averaged Conditional Consequences at 50 Miles as a Function of Interdiction Limit, Peach Bottom $\ldots \ldots \ldots \ldots \ldots \ldots \ldots \ldots \ldots \ldots \ldots$

4-3 Frequency-Averaged Conditional Consequences at 50 Miles as a Function of Interdiction Limit, Sequoyah

4-4 Frequency-Averaged Conditional Consequences at 50 Miles as a Function of Interdiction Limit, Surry

4-5 Frequency-Averaged Conditional Consequences at 50 Miles as a Function of Interdiction Limit, Zion

4-6 Ratio of Averted Offsite Costs to Averted Dose (Person-Rem) as a Function of Interdiction Limit to 50 Miles, Grand Gulf

4-7 Ratio of Averted Offsite Costs to Averted Dose (Person-Rem) as a Function

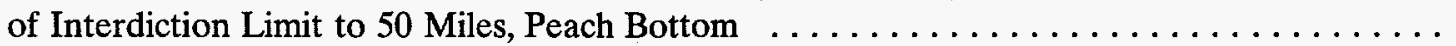

4-8 Ratio of Averted Offsite Costs to Averted Dose (Person-Rem) as a Function of Interdiction Limit to 50 Miles, Sequoyah

4-9 Ratio of Averted Offsite Costs to Averted Dose (Person-Rem) as a Function of Interdiction Limit to 50 Miles, Surry

4-10 Ratio of Averted Offsite Costs to Averted Dose (Person-Rem) as a Function of Interdiction Limit to 50 Miles, Zion

4-11 Total Cost at 50 Miles vs. Interdiction Level, Grand Gulf $\ldots \ldots \ldots \ldots \ldots \ldots \ldots \ldots \ldots$ 4-27

4-12 Total Cost at 50 Miles vs. Interdiction Level, Peach Bottom $\ldots \ldots \ldots \ldots \ldots \ldots \ldots \ldots$. . . . . . .

4-13 Total Cost at 50 Miles vs. Interdiction Level, Sequoyah $\ldots \ldots \ldots \ldots \ldots \ldots \ldots \ldots \ldots$ 4-29

4-14 Total Cost at 50 Miles vs. Interdiction Level, Surry $\ldots \ldots \ldots \ldots \ldots \ldots \ldots \ldots \ldots \ldots$

4-15 Total Cost at 50 Miles vs. Interdiction Level, Zion $\ldots \ldots \ldots \ldots \ldots \ldots \ldots \ldots \ldots \ldots$

5-1 Dollars Per Person-Rem as a Function of SVOL $\ldots \ldots \ldots \ldots \ldots \ldots \ldots \ldots \ldots \ldots$ 


\section{LIST OF TABLES}

Table

Page

2-1 Risks of Latent Health Effects from Low-LET, Low Dose Rate Radiation Doses

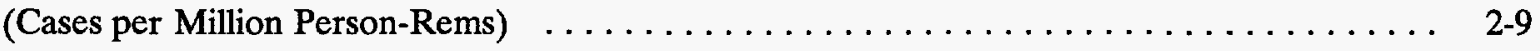

3-1 Mean Earnings of Employed Persons by Age and Gender (In 1990 Dollars) . . . . . . . 3-14

3-2 Discounted Five-Year Earnings and Cumulative Discounted Earnings

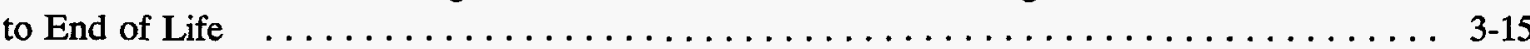

3-3 Costs of Medical Treatment for Latent Health Effects $\ldots \ldots \ldots \ldots \ldots \ldots \ldots \ldots \ldots \ldots$

3-4 Costs of Delayed Health Effects: 1990 Dollars/Person-Rem

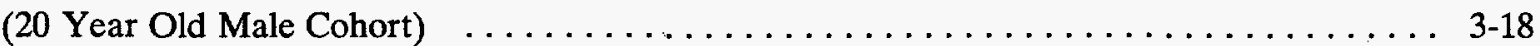

3-5 Costs of Delayed Health Effects: 1990 Dollars/Person-Rem

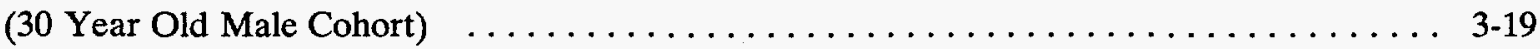

3-6 Costs of Delayed Health Effects: 1990 Dollars/Person-Rem

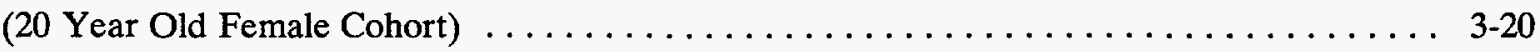

3-7 Costs of Delayed Health Effects: 1990 Dollars/Person-Rem

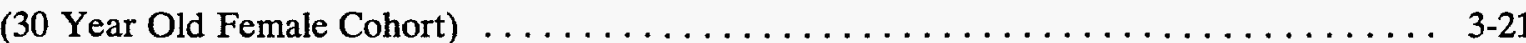

3-8 Estimated Values of Averted Radiation Dose Based on Earnings Loss for

3-9 Costs of Delayed Health Effects: 1990 Dollars Per Person-Rem (Based on Assumed SVOL $=\$ 3$ Million)

3-10 Statistical Value-of-Life for Radiation Related Activities

(Based on Expert Judgment)

3-11 Statistical Value-of-Life from Reduction of Risk Due to Carcinogenic Chemicals

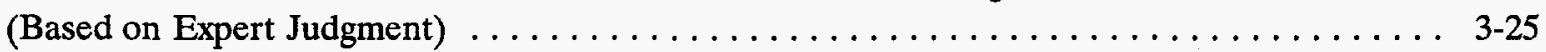

3-12 Occupational Related Statistical Value-of-Life (Based on Expert Judgment) $\ldots \ldots \ldots \ldots$ 3-26

3-13 Occupational Statistical Value of Life (Based on Willingness-to-Accept

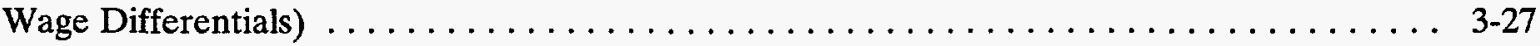

3-14 Value of Life in Transportation Risk Abatement (Based on Revealed Preference) . . . . . . 3-28

3-15 Cost Per Statistical Life from Day-to-Day Products (Based on Expert Judgment) . . . . . . 3-29

3-16 Willingness-to-Pay for Nonradiological Risk Reduction (Population Surveys) . . . . . . . 3-30

3-17 Summary Statistics on the Value of Statistical Life (Million 1990 Dollars) $\ldots \ldots \ldots \ldots \ldots$ 3-31 


\section{LIST OF TABLES (continued)}

Table

Page

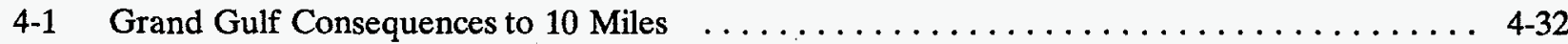

4-2 Grand Gulf Consequences to 50 Miles $\ldots \ldots \ldots \ldots \ldots \ldots \ldots \ldots \ldots \ldots \ldots \ldots \ldots$

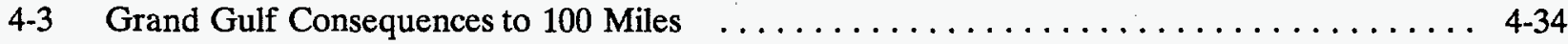

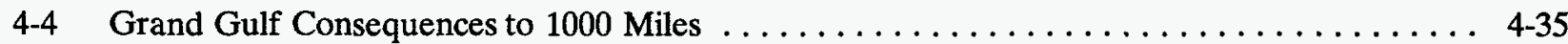

4-5 Peach Bottom Consequences to 10 Miles $\ldots \ldots \ldots \ldots \ldots \ldots \ldots \ldots \ldots \ldots \ldots \ldots$. $\ldots \ldots \ldots$

4-6 Peach Bottom Consequences to 50 Miles $\ldots \ldots \ldots \ldots \ldots \ldots \ldots \ldots \ldots \ldots \ldots \ldots \ldots$

4-7 Peach Bottom Consequences to 100 Miles $\ldots \ldots \ldots \ldots \ldots \ldots \ldots \ldots \ldots \ldots \ldots \ldots .4 \ldots \ldots$

4-8 Peach Bottom Consequences to 1000 Miles . . . . . . . . . . . . . . . . . . . . . . . . . . . 4-39

4-9 Sequoyah Consequences to 10 Miles $\ldots \ldots \ldots \ldots \ldots \ldots \ldots \ldots \ldots \ldots \ldots \ldots \ldots \ldots$

4-10 Sequoyah Consequences to 50 Miles $\ldots \ldots \ldots \ldots \ldots \ldots \ldots \ldots \ldots \ldots \ldots \ldots \ldots \ldots \ldots \ldots$

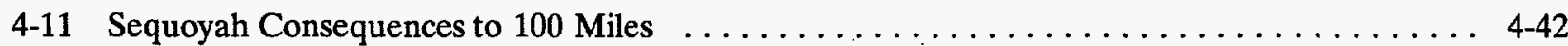

4-12 Sequoyah Consequences to 1000 Miles $\ldots \ldots \ldots \ldots \ldots \ldots \ldots \ldots \ldots \ldots \ldots \ldots \ldots$

4-13 Surry Consequences to 10 Miles $\ldots \ldots \ldots \ldots \ldots \ldots \ldots \ldots \ldots \ldots \ldots \ldots \ldots \ldots \ldots$

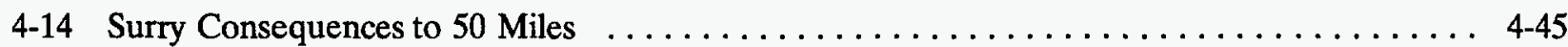

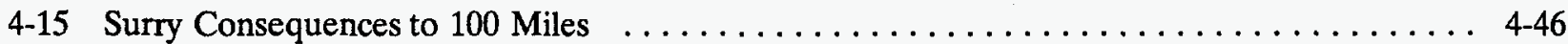

4-16 Surry Consequences to 1000 Miles $\ldots \ldots \ldots \ldots \ldots \ldots \ldots \ldots \ldots \ldots \ldots \ldots \ldots \ldots \ldots \ldots$

4-17 Zion Consequences to 10 Miles $\ldots \ldots \ldots \ldots \ldots \ldots \ldots \ldots \ldots \ldots \ldots \ldots \ldots \ldots \ldots \ldots \ldots$

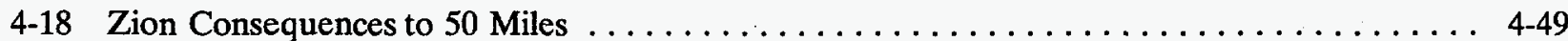

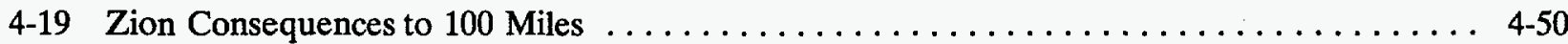

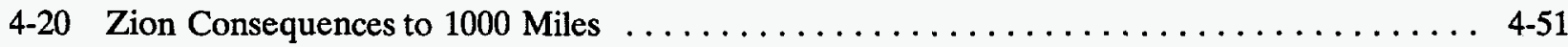

4-21 Summary of Frequency-Averaged Conditional Consequence Results

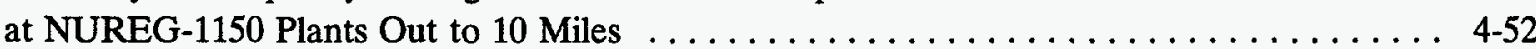

4-22 Summary of Frequency-Averaged Conditional Consequence Results

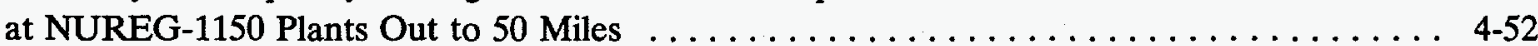

4-23 Summary of Frequency-Averaged Conditional Consequence Results

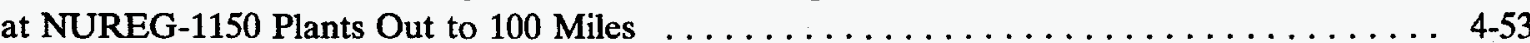

4-24 Summary of Frequency-Averaged Conditional Consequence Results

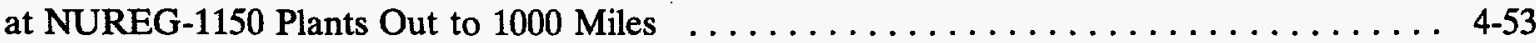

4-25 Centerline Dose for Grand Gulf Source Terms to Specified Distance . . . . . . . . . 4 4-54

4-26 Centerline Dose for Peach Bottom Source Terms to Specified Distance . . . . . . . . . . . . 4-55

4-27 Centerline Dose for Sequoyah Source Terms to Specified Distance $\ldots \ldots \ldots \ldots \ldots \ldots \ldots$. . .56 


\section{LIST OF TABLES (continued)}

Table

Page

4-28 Centerline Dose for Surry Source Terms to Specified Distance $\ldots \ldots \ldots \ldots \ldots \ldots \ldots$. . . . . . . . .

4-29 Centerline Dose for Zion Source Terms to Specified Distance $\ldots \ldots \ldots \ldots \ldots \ldots \ldots \ldots$ 4-58

4-30 Frequency-Averaged Conditional Consequences at Grand Gulf Out to 50 Miles as a Function of Long-Term Interdiction Limit $\ldots \ldots \ldots \ldots \ldots \ldots \ldots$. . . . .

4-31 Frequency-Averaged Conditional Consequences at Peach Bottom Out to 50 Miles as a Function of Long-Term Interdiction Limit $\ldots \ldots \ldots \ldots \ldots \ldots \ldots$. $\ldots$.59

4-32 Frequency-Averaged Conditional Consequences at Sequoyah Out to 50 Miles as a Function of Long-Term Interdiction Limit $\ldots \ldots \ldots \ldots \ldots \ldots \ldots$

4-33 Frequency-Averaged Conditional Consequences at Surry Out to 50 Miles as a Function of Long-Term Interdiction Limit $\ldots \ldots \ldots \ldots \ldots \ldots \ldots \ldots \ldots$

4-34 Frequency-Averaged Conditional Consequences at Zion Out to 50 Miles as a Function of Long-Term Interdiction Limit $\ldots \ldots \ldots \ldots \ldots \ldots \ldots \ldots \ldots$ 4-61

4-35 Frequency-Averaged Conditional Consequences at Grand Gulf Out to 1000 Miles as a Function of Long-Term Interdiction Limit $\ldots \ldots \ldots \ldots \ldots \ldots \ldots \ldots$. . . . . .

4-36 Frequency-Averaged Conditional Consequences at Peach Bottom Out to 1000 Miles as a Function of Long-Term Interdiction Limit $\ldots \ldots \ldots \ldots \ldots \ldots \ldots \ldots$. . . . . . . .

4-37 Frequency-Averaged Conditional Consequences at Sequoyah Out to 1000 Miles as a Function of Long-Term Interdiction Limit $\ldots \ldots \ldots \ldots \ldots \ldots \ldots \ldots$. . . $\ldots 2$

4-38 Frequency-Averaged Conditional Consequences at Surry Out to 1000 Miles as a Function of Long-Term Interdiction Limit $\ldots \ldots \ldots \ldots \ldots \ldots \ldots \ldots$

4-39 Frequency-Averaged Conditional Consequences at Zion Out to 1000 Miles as a Function of Long-Term Interdiction Limit

5-1 Estimated Values of 1990 Dollars Per Person-Rem for Several Illustrative Values

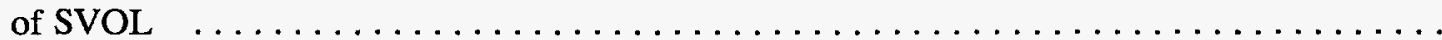

5-2 Estimates of SVOL and Dollars/Person-Rem for Two Discount Rates (Based on Averages of Willingness-to-Pay Studies) $\ldots \ldots \ldots \ldots \ldots \ldots \ldots \ldots \ldots \ldots \ldots$

5-3 1990 Dollars Per Person-Rem Based on HECOM Model $\ldots \ldots \ldots \ldots \ldots \ldots \ldots \ldots \ldots$

5-4 Offsite Damage Costs Per Person-Rem Averted at Five Reactor Sites

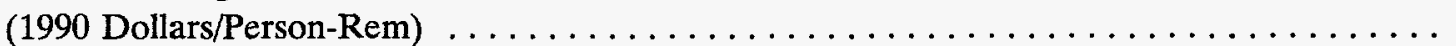

5-5 Dollars Per Person-Rem for Reactor Backfits

(Based on the Sum of Health and Offsite Cost Related Values) $\ldots \ldots \ldots \ldots \ldots \ldots \ldots$ 


\section{ACKNOWLEDGEMENTS}

We thank Arthur Tingle for carrying out the offsite consequence calculations using the MACCS code, Cheryl Conrad for help with the computations and Barbara Kponou for her patience and diligence in the production of this report. We also thank H. Roy Woods, the NRC Program Manager, for his support and guidance. 


\subsection{INTRODUCTION: VALUE-IMPACT CONSIDERATIONS IN RADIATION PROTECTION}

Safety enhancements at nuclear facilities, reactor and non-reactor, are generally designed to reduce the potential exposure of the public and the onsite work force to ionizing radiation from the operation of the facility. The exposures may arise from accidental releases or routine emissions. The value attributed to a safety enhancement is assessed in terms of the expected reduction in exposure of the public or the facility workers over a particular time period, such as a year or over the lifetime of the facility. Additionally, values may also include averted or reduced property damage (such as contamination of land, buildings, crops, etc.).

One element of the decision-making process about the implementation of particular safety systems is the comparison between the monetary cost (the "impact") of the system and the benefits (the "value") it produces by way of reducing radiation exposure. Such a comparison necessarily involves the choice of a coefficient reflecting the monetary worth of a unit of radiation exposure. The considerations underlying this choice are the subject of this report. When the values refer to averted property damage the comparison between impact and value is more straightforward since both are reckoned in the same units, dollars.

Regulatory activities for which value-impact analyses are performed by the Nuclear Regulatory Commission (NRC) encompass all safety enhancements to the facilities and activities of nuclear licensees. These include: backfits to existing nuclear power plants carried out under the Backfit Rules (see below), "forward-fits" to new and/or proposed plants, analysis of the Severe Accident Mitigation Design Alternatives (SAMDAs) carried out as part of the design certification process for new reactor designs, decommissioning of nuclear facilities, safety enhancements to non-reactor facilities, nuclear fuel processing, transportation of nuclear material (e.g., spent fuel rods), and nuclear materials management.

\subsection{Regulatory Requirements (The "Backfit Rules")}

Safety enhancements at commercial nuclear power plants, generally known as "backfits," are defined in 10 CFR 50.109 [1] as:

"The modification of or additions to systems, structures, components, or design of a facility; or the design approval or manufacturing license for a facility; or the procedures or organization required to design, construct, or operate a facility; any of which may result from a new or amended provision in the Commission rules or the imposition of a regulatory staff position interpreting the Commission rules that is either new or different from a previously applicable staff position..."

10 CFR 50.109 provides that the NRC shall require a "systematic and documented analysis ... for the backfits it seeks to impose" in order to demonstrate "that there is a substantial increase in the overall protection of the public health and safety or the common defense and security to be derived from the backfit and the direct and indirect costs of implementation for that facility are justified in view of the increased protection."

10 CFR 50.109 also requires that the analysis of the proposed backfit, in addition to a statement of its specific objectives, should contain an evaluation of:

- the potential change in the risk to the public from the accidental offsite release of radioactive material, 
1 Introduction

- the potential impact on radiological exposure of facility employees, and

- the installation and continuing costs associated with the backfit, including the cost of facility downtime or the cost of construction delay.

Thus, a regulatory value-impact analysis is required as an essential part of the justification for imposing a backfit.

\subsection{Averted Radiation Dose as a Surrogate for Enhanced Public Health and Safety}

In regulatory analyses done by the $\mathrm{NRC}$, values are usually assessed in terms of avoided public radiation exposure measured in units of population dose (person-rem). The benefits to be assigned to a safety enhancement are obtained from the reduction in risk to public (or worker) health resulting from the accidental release of radioactive material. The reduction in risk is the difference in the quantity:

(Frequency of release $\times$ Consequence of release)

evaluated before and after the introduction of the backfit.

In the case of a value-impact analysis of a power reactor backfit, for example, the frequency of release may be taken to be the product of the core damage frequency and the (conditional) probability of containment failure (given core damage), and the consequence of the release as the population dose; the value will be the person-rem per reactor-year avoided by the introduction of the backfit. Over the lifetime of the plant, the value of the backfit is the avoided person-rem per reactor-year multiplied by the remaining years of useful life of the plant.

A comparison of the increased public protection, expressed in averted person-rem, due to the backfit with the dollar costs of its implementation necessarily involves their expression in the same units, usually constant dollars, present value. This requires an assignment of a dollar value to a unit of avoided dose.

\subsection{The Monetary Worth of Avoided Doses}

The monetary worth of avoided dose depends on a number of factors, some of which are, in part, subjective in nature. For example, radiation exposure can lead to the induction of various types of cancers. Premature mortality (or morbidity) and consequent loss of productivity and income are undoubtedly consequences of this exposure which can be objectively estimated from society's standpoint. However, the incidence of disease can also lead to significant pain and suffering in the affected individuals. There is a question of how much value society should place on avoidance of pain and suffering.

Besides radiation-induced sickness, there are other potential consequences of radiological releases which are also difficult to measure in strictly economic terms. In major reactor accidents, such as at Chernobyl, there can be a very large contamination of the natural environment involved; land, forest, water bodies, etc. While the losses due to the contamination of economically productive resources, such as agricultural land, forest products, fisheries, etc., can be quantified in monetary terms, there may be losses of other amenities, such as access to scenic areas, historical sites, etc., whose value is more difficult to quantify.

In the past, various approaches have been used to estimate the monetary value of avoided radiation doses. Among these are economic models for estimating the Statistical-Value-of-Life (SVOL), based, for example, on the "Human Capital" or the "Willingness to Pay" (WTP) methods. Also estimates have been developed in the context of reducing occupational exposure to as-low-as reasonably-achievable (ALARA). At one point or another, each of the methods require subjective judgments about the value of human life, human health and suffering, and human amenities. Government authorities that have responsibility for regulating various aspects of the public health and 


\section{Introduction}

safety cannot escape making such a decision, be it implicitly or explicitly expressed, which assigns a monetary value to human life and welfare.

A primary objective of this report is to discuss and compare the various methods pertaining to radiation safety and to cite illustrative examples of the numerical values that have been derived by various analyses.

\subsubsection{Background and History of the NRC $\$ 1000$ Per Person-Rem Valuation}

For the last two decades, the NRC has used a conversion figure of $\$ 1000$ per person-rem as a monetary valuation of the benefits of avoided dose. This value was originally adopted in the early 1970 s for evaluating the benefits of systems designed to reduce routine emissions of radioactive effluents from nuclear power plants. Later on, the same value was adopted by the NRC for use in decisions on safety improvements, and it has come into widespread use in the value-impact analysis of backfits to nuclear power plants. If monetary inflation factors over the last two decades and the higher risk estimates (of developing latent cancer per rem of dose) of the BEIR V committee (see Chapter 2) are applied, then $\$ 1000$ /person-rem in the early 1970 s, would be closer to $\$ 10,000 /$ personrem at this time.

The problem of ascribing a monetary value to avoided radiation dose in U.S. regulatory decisionmaking arose in the Rulemaking Hearing "Numerical Guides for Design Objectives and Limiting Conditions for Operation to meet the Criterion 'As Low as Practicable' for Radioactive Material in Light-Water-Cooled Nuclear Power Reactor Effluents," amendments to 10 CFR 50, published as Appendix I, 10 CFR 50 [2]. In the record of the Hearing [3], the Commission adopted design objectives for limiting public dose from routine emissions of radioactive liquid and gaseous effluents, iodine and particulates during normal plant operation. In addition to numerical values of limiting doses, the Commission viewed favorably "the application of a cost-benefit analysis as part of the process for determination of the radwaste system to be used." The Commission felt that "Such a cost-benefit analysis requires that both the costs of and the benefits from the reduction in dose levels to the population be expressed in commensurate units, and it seems sound that these units be units of money. Accordingly, to accomplish the cost-benefit balancing, it is necessary that the worth of a decrease of a man-rem ... be assigned monetary values."

However, the problem was on what basis should this assignment be made? The Commission stated that "The record, in our view, does not provide an adequate basis to choose a specific dollar value for the worth of decreasing the population dose by a man-rem." Published studies, at that time, based on different assumptions, which were mentioned in the record of the rulemaking, gave values ranging from $\$ 10 /$ person-rem to $\$ 980 /$ person-rem. The Commission concluded that "there is no consensus in this record or otherwise regarding proper value for worth of a man-rem," and that "we also recognize that selection of such values is difficult since it involves, in addition to actuarial considerations that are commonly reduced to financial terms, aesthetic, moral, and human values that are difficult to quantify."

The basic recommendation of the Commission was to conduct another rulemaking hearing to establish appropriate monetary values for the worth of reduction of public doses. However, "purely as an interim measure," it was recommended that the conservative value of $\$ 1000$ per person-rem be used for the cost-benefit evaluations.

A decade later, NRC issued a Policy Statement on Safety Goals for the Operation of Nuclear Power Plants [4]. In this statement, the Commission adopted qualitative and quantitative design goals for limiting individual and societal mortality risks from 
severe accidents. For use as one consideration in decisions on safety improvements, the Commission adopted a benefit-cost guideline: "The benefit of an incremental reduction of societal mortality risks should be compared with the associated costs on the basis of $\$ 1000$ per person-rem averted." The value proposed was in 1983 dollars and "should be modified to reflect general inflation in the future." This value was intended for trial use for an interim period of two years. Comments received on this value were, as can be expected, widely different. Values ranging from $\$ 100$ /person-rem to over $\$ 1000 /$ person-rem were suggested. No justification was offered for the adoption of this particular value by the Commission.

Since that time, $\$ 1000 /$ person-rem has been generally used by the NRC staff in analysis of plant improvements designed to enhance safety. Although averted person-rems of radiation exposure logically should refer to averted health effects (averted fatalities/injuries), the use of the $\$ 1000$ /person-rem in current backfit analyses has traditionally been acknowledged to reflect all averted losses, health as well as property. As stated in a memorandum [5] from William J. Dircks to NRC Commissioners, "The $\$ 1000$ valuation of a person-rem is assumed to be high enough to include implicit recognition of radioactive release effects other than public health, including offsite property damage."

\subsection{Tradeoffs in Consequence Management}

In the value-impact analysis of reactor backfits for regulatory purposes, the reduction in the expected value of the total population dose over the life of the plant due to the backfit ( $\Delta$ person-rem) is monetized through a conversion coefficient (dollars/ person-rem) and then compared to the cost (dollars) of implementation of the backfit.

The population dose and the resultant health effects arise from several exposure pathways whose relative importance is a function of the time period follow- ing the release. In the short-term, i.e., within a few days following the accident, the important pathways are: inhalation exposure due to breathing of contaminated air; cloudshine exposure from the passage of the radioactive cloud plume; and groundshine exposure from standing on ground contaminated by the deposition of radioactive material.

Short-term exposure and the resultant acute health effects, such as prodromal vomiting, fatal impairment of vital organs, etc., can be reduced by emergency protective actions. These include evacuation and relocation or sheltering of potentially affected populations downwind of the release.

The long-term population dose is due primarily to three exposure pathways: groundshine from living on contaminated land, inhalation exposure from resuspended particles deposited on the ground, and ingestion of contaminated food or water.

The long-term population dose (and thus the number of latent cancers) can be reduced by decontamination of contaminated land and buildings, by relocating people away from contaminated areas, by prohibiting the consumption of contaminated food or the production of crops on contaminated farmland, or by permanently prohibiting the reoccupation of land or property which cannot be decontaminated in a certain period of time in a cost-effective manner.

Each of these actions involve costs to society. The sum of these costs are usually termed as the "offsite costs." The short-term emergency action costs depend on the population immediately affected by the release and the fraction of that population which is assumed to be evacuated and temporarily relocated away from the passage of the radioactive plume. The costs of long-term protective actions depend on the criteria selected for the allowable levels of long-term exposure of potentially affected populations. These criteria, called the "interdiction levels," are expressed in terms of the projected dose 
to an individual over a certain time period from the long-term exposure pathways.

\subsubsection{Cost Impacts of Interdiction Criteria}

The long-term health effects and the offsite costs of reactor accidents are affected by the assumed interdiction level, for contaminated food and land. Relaxation of the interdiction level, i.e., allowing a higher dose over a certain period of time, will lead to higher doses to the population and more latent cancers but will decrease the offsite costs since smaller amounts of property and food will have to be condemned. Conversely, a more stringent interdiction level, i.e., a lower level of dose over the same time period, will lead to smaller health effects but increase the offsite costs. Thus, the two measures of offsite consequences-health effects and offsite costs-are inversely related and a particular choice of an interdiction level is, in effect, a trade-off between these two consequence measures.

At any given interdiction level, the total costs of an accidental release are the sum of the offsite costs calculated at that particular interdiction level and the monetary equivalent of the health effects, at that same interdiction level. For a given source term involving a release of long-lived radionuclides, e.g., isotopes of cesium, strontium, lanthanum, etc., the offsite costs and the health costs can, in principle, be calculated using a consequence code for a particular choice of the interdiction level. As the interdiction level is varied, these two costs will vary inversely, the health costs increasing as the interdiction level is relaxed and the offsite costs decreasing. The general shape of the curves of the two costs as a function of interdiction level is shown in Figure 1-1.

\subsubsection{Optimization of Tradeoffs}

Results from consequence codes for specific source terms indicate that the offsite costs are, in general, nonlinear and increase more sharply as the interdiction level is decreased following a law of diminishing returns. The health costs, however, are proportional to the number of latent cancers induced. Given a constant risk coefficient (i.e., assuming a linear dose response curve, a reasonable assumption at the interdiction level usually considered), the number of latent cancers and, thus, the health costs will vary more linearly with the interdiction level.

The total cost curve will then vary as shown in Figure 1-1. At some interdiction level, the total cost will be a minimum, and the minimum of the total cost curve can be used to derive an optimum interdiction level for calculating the offsite costs. Conversely, given the choice of a particular interdiction level, the minimum of the total cost curve can be used to obtain the optimal monetary equivalent of averted latent cancers. The averted costs (either offsite costs or total costs) to averted dose ratio obtained at that optimum can then be used to set the dollars per person-rem guideline for the purposes of regulatory analysis of backfits.

The results of detailed, site-specific consequence calculations indicate that the offsite costs and doses have considerable variability as well as inherent uncertainty due, for example, to the source term (magnitude and timing of releases), and site-specific features such as weather, population distribution, property values, etc. Another source of variability influencing the calculation, as pointed out above, is the choice of the interdiction level. However, the choice of one particular number for the valueimpact guideline, such as $\$ 1000$ per person-rem, has been based on the consideration that it is conservative, i.e., it offers an envelope for the avoided costs/avoided dose ratio of a broad range of accident sequences, source terms, and site-specific factors. 
1 Introduction

\subsection{Plan of the Report}

The plan of this report is as follows:

Chapter 2 contains an overview of the recent studies on the health risk of radiation exposure. The most notable among these studies is BEIR V, where the long-term risk coefficient for developing cancer as a result of radiation exposure has increased by a factor of approximately three - four compared to the value recommended by BEIR III a decade ago.

Chapter 3 is devoted to a review of various methods for estimating the Statistical-Value-of-Life (SVOL), including the Human Capital (or Loss of Output) and the Willingness-to-Pay (WTP) concepts in the economic valuation of risk and safety. Data from a number of surveys of the nuclear, chemical, and hazardous employment industries are synthesized to arrive at an estimate of the SVOL for regulatory decision-making purposes.

Chapter 4 contains a detailed review of the offsite costs of reactor accidents derived from the consequence analysis of the plants studied in the NUREG-1150 program. Data from the NUREG1150 results has been reviewed to provide an estimate of the offsite costs and doses at each of the sites averaged over the frequency of the releases.

Chapter 5 summarizes the results of the previous chapters to arrive at various alternative figures for the dollar/person-rem ratio.

Appendix A provides a review of the Chernobyl accident with a focus on the economic costs.

\subsection{References}

1. U.S. Nuclear Regulatory Commission, Domestic Licensing of Production and Utilization Facilities-Backfitting, Code of Federal Regulation, Chapter 10, Part 50.109(a), November 1988.

2. U.S. Nuclear Regulatory Commission, Numerical Guides for Design Objectives and Limiting Conditions for Operation to Meet the Criterion "As Low As Is Reasonably Achievable" for Radioactive Material in Light-Water-Cooled Nuclear Power Plant Effluents, 10 Code of Federal Regulation, Part 50, Appendix I, November 1986.

3. U.S. Nuclear Regulatory Commission, Docket No. RM-50-2, 1974.

4. U.S. Nuclear Regulatory Commission, "Safety Goals for Nuclear Power Plant Operation," NUREG-0880, Rev. 1, May 1983.

5. Memorandum, W. J. Dircks to Commission, "Basis for Quantifying Offsite Property Losses," October 23, 1985. 
1 Introduction

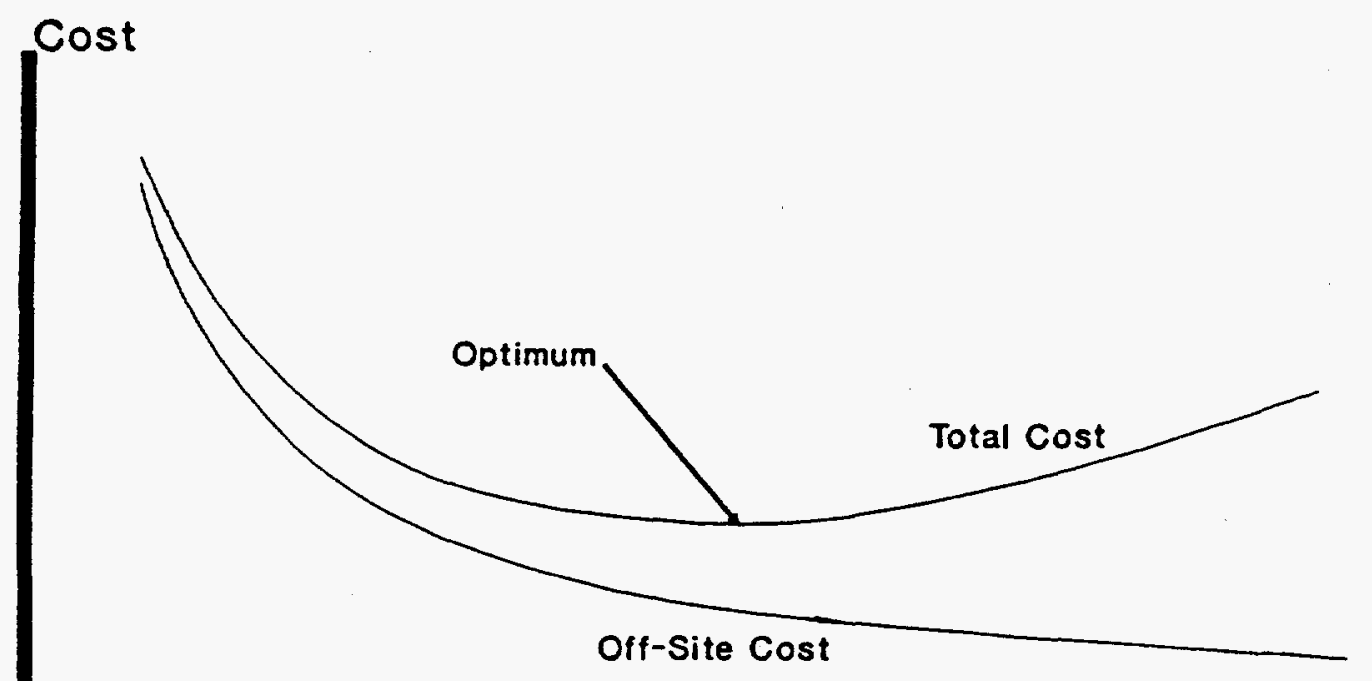

Health Cost

Interdiction Criterion

(Allowable long-term dose)

Figure 1-1. Cost as a Function of the Interdiction Level 


\subsection{RADIATION EXPOSURE RISKS}

As noted in Chapter 1, one of the benefits of a backfit to avert or mitigate a severe accident in a nuclear power plant is a reduction in the public risk of exposure to radiation. The risk reduction might result from a lower accident probability and/or from a mitigation of radioactive releases. In either case, it is necessary to evaluate the change in radiation risks to the public resulting from the backfit.

The evaluation of the benefits resulting from reduction in radiation risks requires three separate steps:

1. An estimate of the change in the probability and/or magnitude of radiation dose to the public;

2. An evaluation of the difference in public health consequences; and

3. Conversion of the public health consequences into units that are compatible with other benefits and costs.

\subsection{Review of Health Effects of Radiation}

The consequence code, MELCOR Accident Consequence Code System (MACCS) [1], used to calculate the consequences of severe nuclear power plant accidents, which are presented as examples in Chapter 4, requires radiation risk data of two general types:

1. The acute effects of large radiation doses received during the initial phases of the accident that result in injuries or fatalities within the first few months following exposure; and

2. The chronic effects of lower radiation doses received over long periods that influence decisions about land interdiction and population relocation.

The original version of MACCS used dose/response models published in 1985 by Evans, et al. [2], which in turn drew heavily from the 1980 BEIR III report [3]. Subsequently, the MACCS models were modified to incorporate refinements and reflect additional data from the continuing life-span studies of the Hiroshima and Nagasaki A-bomb survivors. The scientific bases for the refinements are described in the 1989 report of S. Abrahamson et al. [4] and summarized in a 1990 revised edition of the original Evans report [5]. The latter presents a compilation of formulae and numerical coefficients for calculating the risk of the various early and latent health effects as a function of radiation dose to the critical organs. Another objective of the NUREG/CR-4214 revision was to provide upper and lower estimates of the parameters which reflect the uncertainties.

In 1990, the Committee on the Biological Effects of Ionizing Radiation (BEIR V) of the National Research Council published its final report [6] which included revised dosimetry for the A-bomb survivors, several years of additional experience of the cohort in the Life-Span study, and new analytical approaches to the risk calculations. The cancer risk estimates of BEIR $V$ are larger than BEIR III. Based on the BEIR III Linear-Quadratic Dose Response Model, the BEIR V estimate is approximately 3 times the relative risk and 10 times the absolute risk* projection of BEIR III. (Compare Table V-1, pg 145 of [3] with Table 4-2, pg 172 of [6]). The BEIR $V$ risk coefficient is approximately $5 \times 10^{-4}$ latent cancer fatalities per person-rem; if nonfatal cancers are included the total BEIR $V$ risk coefficient is about $7.3 \times 10^{-4}$ cancers per person-rem. The relatively large differences between the BEIR III and V estimates are surprising in view of the fact that these studies were only a decade apart and both studies depended primarily on the same human cohorts.

${ }^{*}$ The BEIR committees define relative risk as the ratio: exposed/unexposed risks. Absolute risk is defined as the arithmetic difference: [exposed risk - unexposed risk]. 
A revision of NUREG/CR-4214 has been prepared [7] which takes account of the revised risk estimates contained in the BEIR V report. The MACCS code has also been revised to incorporate the BEIR $V$ risk factors [8].

\subsection{Uncertainties in Dose/Response Relationships}

The effects of radiation on human health have been the subject of intensive world-wide research for several decades. In addition to the BEIR Committees of the National Research Council, the problem has been addressed on a continuing basis by the International Commission on Radiation Protection (ICRP), the National Council on Radiation Protection and Measurements (NCRP), the United Nations Scientific Committee on the Effects of Atomic Radiation (UNSCEAR), and the radiation safety commissions in many other nations. Obviously, much is known about the relationships between radiation and health, but at the same time many quantitative facts remain elusive.

Significant doses of radiation can produce three general types of health effects, i.e., acute radiation injuries, delayed somatic effects (primarily cancer) and genetic disorders. Which, if any, of these result from a single or sustained exposure depend on many factors, e.g., the total dose received, the nature of the radiation, the rate at which the dose was administered, the organs that were irradiated, and the age and sex of the individual.

Whole body doses exceeding 150 rem can produce acute radiation injuries. The acute effects of large radiation doses are fairly well established from medical experience gained from a relatively small number of victims of severe accidents. About half of the individuals receiving instantaneous doses in the range of 300 rem will die within a few weeks with minimal medical treatment. With supportive treatment the $\mathrm{LD}^{50}$ value (dose level at which half of the exposed population is expected to die) increases to about 450 rem.
Survivors of acute injuries have an increased risk of delayed somatic and genetic effects as also do individuals that have received smaller doses than those resulting in symptoms of acute injuries. Risks of delayed effects particularly from smaller doses, i.e., effective dose equivalent whole body (EDEWB) of less than about $50 \mathrm{rem}$, have proved more difficult to quantify.

The principal late somatic effects of radiation doses are cancers arising in various organs and tissues, and, less frequently, leukemia. The latent period between exposure and the clinical appearance of cancer is generally of the order of ten to thirty or more years. A cancer induced by radiation cannot be distinguished from one resulting from other causes. Radiation induced leukemia stands out because this normally rare disease has a relatively short latency of two to four years [3] and often a correlation with exposure to radiation can be established.

In principle, at least, dose/response relationships can be derived from analyses of the medical histories of well-defined population cohorts that have received known radiation doses. Given such a cohort, statistical methods must be used to determine the number of health effect cases that are in excess of the natural rate of occurrence. However, even though epidemiological studies of this type have been underway for many decades, substantial uncertainties remain in the dose/response relationships for late somatic effects.

The dose/response uncertainties become greater as the doses become smaller. It has become customary to assume that there is no threshold for damage, i.e., a dose below which no health risks are present. However, for small doses, causality is difficult if not impossible to establish. Prompt symptoms cannot be detected. Late somatic and genetic effects cannot be distinguished from those occurring "spontaneously" or from other unidentified causes. 
The natural background radiation that is an inescapable component of the Earth's environment can serve as a useful point of reference for discussion of health effects resulting from low-level radiation. The levels of individual exposure to environmental radiation depend on geological surroundings, habitat, altitude, and sources of food and drink. A recent estimate made by the National Council on Radiation Protection and Measurements (NCRP) indicates that the population of the United States receives an average annual dose of approximately 0.300 rem per year [9]. Integrated over the population of the United States, this corresponds to approximately $75 \times 10^{6}$ person-rems per year. The present estimate, $0.300 \mathrm{rem} / \mathrm{year}$, is about three times larger than an earlier NCRP estimate of 0.110 rem/year [10]. The increase is due primarily to revised estimates of average indoor radon doses.

There are large variations in the doses received from natural background. People living at high elevations receive much larger doses on the average than those living at sea level. In some localities, radioactive ore deposits raise the dose rates to as much as ten times U.S. average dose levels. However, despite the large variation in natural background radiation, it has not been possible to correlate health effects with the variations. Relevant to this, BEIR III noted:

"dose rates of gamma or X-rays of about 100 mrads/yr are detrimental to man. Any somatic effects at these dose rates would be masked by environmental or other factors that produce the same type of health effects as does ionizing radiation... For higher dose rates-e.g., a few rads per year over a long period-a discernible carcinogenic effect could become manifest." ([3], pg 3.)

BEIR $\mathrm{V}$ notes that in areas of high background radiation, there is an increased frequency of chromosome aberration, but no increase in the frequency of cancer has been correlated with high natural background radiation ([6], pg 385).
Few suitable cohorts in the human population have been identified which have the potential of yielding reliable dose/response data for relatively small radiation doses, ${ }^{* *}$ i.e., single doses in the range of $10 \mathrm{rem}$, or sustained dose rates in the range of 1 to 5 rem per year. Many apparently obvious "candidate cohorts" fail to meet the statistical requirements for one reason or another.

One such example of special interest might be a group of radiation workers for which reasonably accurate dosimetric records have been kept. Offhand, it would appear that many groups who deal regularly and professionally with ionizing radiation would provide excellent cohorts for the needed data. However, in recent decades during which accurate occupational exposure records have been maintained, the accumulated doses have averaged only a few rem. For such small exposures, the size of the required cohort is impractically large. Of course, this should be no surprise, since the established and enforced standards have been designed to protect the workers. In earlier times many X-ray and atomic energy workers undoubtedly received significantly larger doses, but their exposures were not adequately monitored. For these and other reasons, the occupational cohorts have not yielded much information about dose/response relationships except to provide an assurance that risk estimates obtained by other means are not grossly understated.

In order to obtain a statistically significant result from an epidemiologic study, the required size of the cohort increases rapidly as the doses become smaller. For example, for a single whole body dose of $10 \mathrm{rem}$, a cohort of approximately 60,000 individuals would have to be followed for a lifetime to obtain a statistically significant value of the risk.

Most dose/response data that are generally accepted have been derived from a few cohorts which ** "Dose" as used in this report refers to effective dose
equivalent or collective effective dose equivalent. 


\section{Radiation Exposure Risks}

received relatively large doses. Fortunately, from the viewpoint of public health, the number of such cohorts is limited. The most important single cohort is composed of 120,321 survivors of the Hiroshima and Nagasaki atomic bombs. Other high-dose cohorts include several groups of patients that received radiotherapy for several specific diseases. The latter cohorts are smaller in size and less representative of the age and health distribution of the normal population.

The Life Span Study (LSS) of the atomic bomb survivors represents a major international effort to assemble and analyze the data. Presumably, the effort will continue for several more decades, and further changes in the conclusions can be expected. Mortality data for the period 1950-1985 are now complete, but the data will continue to unfold as the younger age groups reach the period in life when latent cancers are expressed.

The LSS has one fundamental difficulty--that of estimating the radiation dose equivalent received by each individual in the cohort. Even today, 45 years after the exposures, the dose estimates are being revised, including the neutron component of the doses. These revisions partially account for the differences in the BEIR III and V evaluations.

The dependence of dose/response data on high-dose cohorts presents a further difficulty--that of extrapolation to low-dose exposures. BEIR III reveals the scientific controversies that arise in such extrapolations ([3], pg iii).

The Chernobyl accident has the potential of yielding valuable results in the years ahead provided that adequate data are collected on the individual doses and lifetime health records.

In light of the foregoing discussion, it must be concluded that the radiation risk estimates relating to long term low-dose radiation risks resulting from contamination following a severe reactor accident are subject to large uncertainties that are unlikely to be reduced in the foreseeable future. The uncertainties are in the range of an order of magnitude.

\subsection{Other Recent Studies}

Two recent studies were targeted by the NRC Staff as possibly being worthy of examination to evaluate their relevance, if any, to Regulatory Analysis:

1. A major epidemiologic survey by the National Cancer Institute of cancer mortality in populations living near U.S. nuclear installations [11]; and

2. Epidemiological studies in the United Kingdom which claim to have revealed a previously undetected radiation/health mechanism [12].

\subsubsection{The National Cancer Institute Survey}

Alleged "leukemia clusters" in the vicinity of nuclear facilities in the United Kingdom (see Section 2.3.2) prompted a major epidemiologic study by the National Cancer Institute (NCI) of the United States Department of Health and Human Services. The objective was to determine whether there was evidence of increased leukemia or cancer in the vicinity of major U.S. nuclear facilities.

The NCI study encompassed most major Federal nuclear facilities and those commercial nuclear power plant sites that were in operation prior to 1982. The analyses were carried out at the county level, comparing "study" counties which housed nuclear installations with "control" counties of similar demographic and environmental composition. Where possible, three control counties were chosen for each study county. In some cases, the study county did not actually contain the nuclear facility but was closely adjacent thereto. All together, 107 study counties were compared with 292 control counties.

The data analyzed consisted of cancer records covering the period 1950-1984. In this span of time, 
there were approximately 900,000 cancer deaths in the study counties and 1,800,000 in the controls. The data were reduced to standardized mortality ratios (SMR), which are the ratios of the actual number of deaths in each county normalized to the number expected at U.S. rates. SMRs were derived for the time periods before and after startup of each nuclear facility for both the study and control counties. In addition, the analyses were carried out for five age groups as well as for the combined ages.

The study concluded that it could find no evidence of any cause-effect relationship between the nuclear facilities and cancer rates in neighboring populations. If any excess cancer risk was present during the period covered by the data as a result of the operation of the facilities, it was too small to be detected by the epidemiologic methods used for the study. For example, the report does not confirm allegations of large excess cancer rates in the vicinity of several older national defense facilities, such as Rocky Flats, Hanford, and Fernald. It was noted, however, that the data base would not have revealed any highly localized concentrations of abnormally high or low rates.

The study also acknowledged that the conclusions were premature for some sites, i.e., the data for those facilities that began operation only a few years before 1984 would not disclose abnormal rates because of the latency periods for most cancers. This reservation would apply to many commercial nuclear power plant sites.

The NCI study appears to have little relevance to backfit analysis, because there has been no accident in the United States that has resulted in a major radioactive release. The highly improbable severe accidents studied for backfit considerations involve population doses in the range of ten million personrem, whereas doses from routine releases from commercial nuclear power plants have been in the range of a few hundred person-rem (see, e.g., [13]). Even as a consequence of the Three Mile Island accident, the population dose commitment was only about 1300 person-rem.

\subsubsection{The United Kingdom Studies}

In 1983, a long-term epidemiological study in the UK was initiated in response to a television program which alleged an excess of childhood leukemia in the vicinity of the Sellafield nuclear fuel reprocessing plant located near Seascale in West Cumbria. In one of a series of reports from the project, M.J. Gardner et al. [12] concluded that radiation doses to a human male prior to conception can result in leukemia in his offspring. If this conclusion is confirmed, it is a radiation/health effect mechanism that has not been detected previously.

The induction of leukemia by ionizing radiation is well established, although the disease can also be caused by other factors $[3,12]$. Normally, the incidence of leukemia is rare. Thus, the occurrence of only a few extra cases above the expected very low rates can be indicative of an unusual situation in which radiation is usually one of the prime suspects as the causative agent. In the case of area around the Sellafield plant, there did indeed appear to be a significant excess of childhood leukemia in the years from 1950 through 1985; however, the levels of radioactive discharges to the atmosphere and sea were much too small to account for the excess [14].

The objective of the Gardner study was to examine whether there were causative factors related to the plant. Investigations were carried out on 52 cases of leukemia, 22 cases of non-Hodgkin's lymphoma, and 23 cases of Hodgkin's disease occurring in people born in the area between 1950 and 1985 for whom the diseases were diagnosed before the age of 25 . A "case-control" method was used for the study in which each individual victim ("case") was matched with one or more "controls" of similar date of birth, sex, and background. By means of medical records, questionnaires, and employment records, a statistical search was made to identify differences between the victims and the controls in search of some causative link for the disease. Included in the analyses were data on maternal abdominal radiographic examinations 


\section{Radiation Exposure Risks}

and viral infections during pregnancy, social class based on occupation of the father, school attendance, fish eating habits, playing in the sand on the beaches, geographical distances from the nuclear plant, etc. The strongest correlation found was with preconception exposure of the father to ionizing radiation in his occupation at the nuclear facility.

It was concluded that "an effect of ionizing radiation on fathers may be leukemogenic in their offspring, although other, less likely explanations are possible" [12]. The authors note that the observed finding is the first of its kind with human data; however, they consider it to be plausible in terms of animal data. Irradiation studies on mice have shown that paternal exposures to x-rays induced heritable tumors in first and second generation progeny [15], which suggests that this effect might operate through germline mutations.

The Gardner data do not yield dose/risk estimates for the effect. In four cases, the occupational radiation doses received by the fathers were in the range of 100 to $188 \mathrm{mSv}$ ( 10 to $18.8 \mathrm{rem}$ ). If the leukemogenic risks were large for accumulated radiation doses of this magnitude, it seems unlikely that the mechanism could have escaped detection until this late date, although the authors point out that "relevant studies have largely not been undertaken." Also, it is noted that this effect was not observed in the offspring of 7387 fathers among the Japanese atomic bomb survivors.

Followup studies on the Sellafield data and analyses have been undertaken and the conclusions of Gardner, et al. [12] have been questioned [16]. In an effort to resolve the uncertainty as to whether the "Gardner Mechanism" exists or not, the United Kingdom Department of Health and the Health and Safety Executive (HSE) are reported to have initiated a joint three-year epidemiological study [17].

Although it is obviously too early to make strong conclusions about the impact of this proposed new radiation/health mechanism on radiation protection standards, it seems unlikely to lead to major revisions. The dose/risk estimates for low-level radiation are integrations over many factors. The direct effects, i.e., the induction of leukemia and cancer in the irradiated individual, appear to constitute the largest fraction of the risk. Other established risk factors, e.g., the induction of leukemia and cancer by radiation doses in utero and genetic effects, appear to be small by comparison. Thus, radiation standards designed to provide "reasonable" protection against the direct effects are generally considered adequate to protect against mutagenic effects.

For these reasons, we conclude that the UK studies on leukemia clusters around British nuclear facilities are not relevant to the value/impact analyses of backfits designed to reduce the risk of severe accidents.

\subsection{Risks of Latent Health Effect from Low- LET, Low Dose Rate Radiation Doses}

For purposes of estimating the value of averted doses of Low-LET radiation for exposures occurring at low dose rates $(<0.1$ Gy per hour), the health effect models proposed by S. Abrahamson, et al., [7] have been used in this report. The Central Estimates for cancer incidence and fatalities are summarized in Table 2-1. The risks for non-fatal cancer were derived by subtracting the fatality risks from the incidence risks. The latency periods for each cancer type were taken from [5].

Note that the risks assume that leukemia and bone cancer are 100 percent fatal. Reference [6] notes that this is no longer strictly true because of improved methods of treatment; however, reliable statistics on the rate of non-fatal cases are not yet available, and in any event this would cause only small adjustments in the risk estimates. It is assumed that fatalities from skin cancer and benign thyroid nodules are negligible. 
For each cancer type, $j$, estimates of the value of averted radiation dose, $V_{j}$, can be made by multiplying the risk, $R_{j}$ (number of cancers of type $\mathrm{j}$ induced per person-rem), by the estimated total monetary costs, $C_{j}$, associated with that particular type of cancer. The total value, $V$, is obtained by summing the products over all cancer types:

$$
V=\sum_{j} R_{j} \times C_{j}
$$

where $V$ is expressed in Dollars per Person-Rem.

The monetary costs, $C_{j}$, of cancer type $\mathrm{j}$ include the costs of medical treatment and decrements resulting from illness and life-shortening due to premature death from that particular cancer. Various approaches to the calculation of these costs and the values of $V(\$ /$ Person-Rem $)$ are discussed in the next chapter.

\subsection{References}

1. H. N. Jow, J. L. Sprung, J. A. Rollstin, L. T. Ritchie, D. I. Chanin, "MELCOR Accident Consequence Code System (MACCS)," NUREG/CR-4691， SAND86-1562， Sandia National Laboratories, February 1990.

2. J.S. Evans, D.W. Moeller and D.W. Cooper, "Health Effects Model for Nuclear Power Plant Accident Consequence Analysis," NUREG/CR-4214, SAND85-7185, Sandia National Laboratories, U.S. Nuclear Regulatory Commission, Washington, DC, 1985.

3. National Research Council, Committee on the Biological Effects of Ionizing Radiation (BEIR III), "The Effects on Populations of Exposure to Low Levels of Ionizing Radiation: 1980," National Academy of Science Press, Washington, DC, 1980.
4. S. Abrahamson, M. Bender, S. Book, C. Buncher, C. Denniston, E. Gilbert, F. Hahn, V. Hertzberg, H. Maxon, B Scott, W. Schull, and S. Thomas, "Health Effects Models for Nuclear Power Plant Accident Consequence Analysis, Low LET Radiation, Part II: Scientific Bases for Health Effects Models," NUREG/CR-4214, SAND85-7185, Rev. 1, Part II, Sandia National Laboratories, U.S. Nuclear Regulatory Commission, Washington, DC, May 1989.

5. J. S. Evans, "Health Effect Models for Nuclear Power Plant Accident Consequence Analysis, Low LET Radiation, Part I: Introduction, Integration, and Summary," NUREG/CR-4214, SAND85-7185, Rev. 1, Part I, Sandia National Laboratories, U.S. Nuclear Regulatory Commission, Washington, DC, Jan. 1990.

6. National Research Council, Committee on the Biological Effects of Ionizing Radiation (BEIR V), "Health Effects of Exposure to Low Levels of Ionizing Radiation," National Academy of Science Press, Washington, DC, 1990.

7. S. Abrahamson, M. A. Bender, B. B. Boecker, E. S. Gilbert, B. R. Scott, "Health Effects Models for Nuclear Power Plant Accident Consequence Analysis, Modifications of Models from Recent Reports on Health Effects of Ionizing Radiation, Low LET Radiation, Part II: Scientific Bases for Health Effects Models," NUREG/CR-4214, Rev. 1, Part II, Addendum 1, LMF-132, Inhalation Toxicology Research Institute, Lovelace Biomedical and Environmental Research Institute, U. S. Nuclear Regulatory Commission, Washington, DC, August 1991. 
2 Radiation Exposure Risks

8. The MACCS code has been recently revised (Version 1.5.11.1) to incorporate the new BEIR $\mathrm{V}$ and ICRP risk factors. (MACCS Version 1.5.11.1, Documentation Package for a Maintenance Release of the Code, Draft, Sandia National Laboratories, June 29, 1992.)

9. National Council on Radiation Protection and Measurements, "Ionizing Radiation Exposures of the Population of the United States," Report No. 93, 1987.

10. National Council on Radiation Protection and Measurements, "Natural Background Radiation in the United States," Report No. 45, 1975.

11. S. Jablon, Z. Hrubec, J. D. Boice, Jr., and B. J. Stone, "Cancer in Populations Living Near Nuclear Facilities," National Cancer Institute, U.S. Department of Health and Human Services, NIH Publication No. 90-874, July 1990.

12. M. J. Gardner, M. P. Snee, A. J. Hall, C. A. Powell, S. Downes, and J. D. Terrell, "Results of Case-Control Study of Leukemia and Lymphoma among Young People near Sellafield Nuclear Plant in West Cumbria," British Medical Journal, Vol. 300, pp 423-429, 1990.
13. V. L. Sailor and J. J. Colbert, "Summary of Historical Experience with Releases of Radioactive Materials from Commercial Nuclear Power Plants in the United States," NUREG/CR-4068, BNL-NUREG-51843, Brookhaven National Laboratory, U.S. Nuclear Regulatory Commission, Washington, DC, March 1985.

14. D. Black, "Investigation of the Possible Increased Incidence of Cancer in West Cumbria," London, HMSO, 1984.

15. T. Nomura, Nature 1982: 296:575-7.

16. Nuclear News, Vol. 36, No. 15, December 1993, pg. 68.

17. Nuclear News, Vol. 36, No. 15, December 1993, pg. 76. 
Table 2-1 Risks of Latent Health Effects from Low-LET, Low Dose Rate Radiation Doses (Cases per Million Person-Rems)

\begin{tabular}{|c|c|c|c|c|}
\hline Health Effect & $\begin{array}{c}\text { Latency Period }^{\mathrm{a}} \\
\text { (years) }\end{array}$ & $\begin{array}{c}\text { Incidence Rate } \\
\text { (per } 10^{6} \text { P-R) }\end{array}$ & $\begin{array}{c}\text { Mortality Rate } \\
\text { (per } 10^{6} \text { P-R) }\end{array}$ & $\begin{array}{c}\text { Non-Fatality Rate } \\
\text { (per } 10^{6} \text { P-R) }\end{array}$ \\
\hline Leukemia & 2 & 49 & 49 & 一 \\
\hline Bone Cancer & 2 & 4.5 & 4.5 & 一 \\
\hline Breast Cancer & 10 & 159 & 54 & 105 \\
\hline Lung Cancer & 10 & 86.5 & 78 & 8.5 \\
\hline G-I Cancer & 10 & 287.5 & 168 & 119.5 \\
\hline Thyroid Cancer & 5 & 72 & 7.2 & 64.8 \\
\hline Benign Thyroid Nodules & 10 & 107.2 & - & 107.2 \\
\hline Skin Cancer & 10 & 444 & - & 444 \\
\hline Other Cancer & 10 & 276 & 138 & 138 \\
\hline Total Risks & & 1486 & 499 & 987 \\
\hline
\end{tabular}

Source: Ref. [7], Tables 3.21 and 3.22 (central estimate).

${ }^{a}$ Latency periods are from Ref. [5].

${ }^{b}$ Non-fatality rate obtained by subtracting mortality rate from incidence rate.

${ }^{c}$ Risks for breast cancer are for a population composed of 50 percent females. 


\subsection{THE MONETARY COSTS OF LATENT HEALTH EFFECTS}

\subsection{The Statistical Value of Life (SVOL)}

For regulatory purposes, the health consequences of radiation doses must be expressed in units that can be compared with other damages from a radiation release (loss of production, abandonment of property and buildings, etc.) and with the costs of potential safety enhancements for reducing the risks of an accident and/or mitigating its consequences. This implies assigning a monetary value to human injuries and fatalities. Whatever method is utilized to make this assignment will inevitably require societal judgments to be made at some point in the analyses about the Statistical Value of Life (SVOL) to be used in the regulatory decision making process.

This Chapter summarizes studies on the statistical value of life that are pertinent to the analysis of risk reduction at nuclear power plants and other nuclear facilities which pose a potential radiological hazard. A number of methods have been suggested for valuing the benefits of safety measures and costing of risk. Two broad sets of objectives seem to underlie these methods: national output maximization and social welfare maximization [1]. In the output based method, the cost of an incidence (fatality or illness) is estimated to be the discounted present value of the loss of the person's future output (or earnings) due to the incidence. Allowances are typically made for non-marketed output (such as housewives' services) and various other costs, such as medical and legal expenses. The main objection to the output based method is based on the argument that most people value safety because of their aversion to death and injury, not because they want to save productive resources and enhance the Gross National Product (GNP). There have been some ad-hoc methods suggested to deal with this criticism: the present value of future output is multiplied by a factor that takes into account "pain, grief, and suffering" [1].
In the social welfare maximization approach, the individual willingness-to-pay for safety is estimated, and aggregated over all the affected individuals. Economists appear to favor willingness-to-pay (WTP) because, in theory, it reflects a person's real utility (or value) of safety. Also, the notion is that, if there was a market for "buying" safety, then this approach would yield the price that consumers would be willing to pay. In most cases where public policy is involved, the analyst would estimate the maximum willingness-to-pay of individual stakeholders and average these figures over all the people involved.

It is usually much easier and more straightforward to estimate the discounted present value of future output than willingness-to-pay. In addition, as we will discuss below, the WTP approach has a number of inherent difficulties associated with it. The strongest argument for the WTP approach is that it is better at conceptually assessing the premium that people put on "pain, grief, and suffering" than merely evaluating lost output or income. Given the advantages and disadvantages of each approach, one cannot say that either is preferred by an overwhelming preponderance of evidence. In recent years, the WTP approach is the one that appears to have gained the most popularity among risk analysts and economists. In this chapter we have summarized available evidence on the estimation of the statistical value of life using both the loss of output and the WTP approach.

\subsection{The "Human Capital" Approach to the SVOL}

Nieves and Tawil of Pacific Northwest Laboratory have developed "The Health Effects Costs Model" (HECOM), based on a loss of earnings approach, which evaluates the direct and indirect costs of health consequences due to radiation effects [2]. 
Direct costs include expenses for medical treatment for specific acute injuries, and delayed somatic and genetic effects. Indirect costs are evaluated in terms of "loss of human capital" (i.e., the productivity loss to society as a result of illness and premature death). Productivity loss is measured in terms of loss of wages, and is sometimes modified to include nonwage-earning labor (household services). The model includes a data base representative of the average mid-1980s U.S. demographic distribution. Site specific data can be substituted.

The Nieves and Tawil report presents a useful and detailed discussion on the loss of human capital approach. As discussed above, the value judgment made overtly in this approach is that the societal costs of physical and psychological suffering are neglected.

The direct and indirect costs of delayed effects are expressed in terms of present value, being discounted from the time at which the cost or loss of human capital occurred. It must be emphasized that the process of discounting future medical costs and lost wages must not be confused with the discounting of future radiation exposures.

\subsubsection{Estimates of the Value of Averted Dose Using the Human Capital Approach}

Following the general methods of the HECOM Model [2], we have made estimates of the dollar value of a person-rem of radiation dose for 20- and 30-year old, male and female cohorts.

The mean earnings of the four cohorts were based on Table A.18 of the HECOM Report, normalized to 1990 dollars. These are listed in Table 3-1. Note that the human capital approach as used here considers only earnings and gives no value to the labor of the homemaker. Hence, the large disparity between the male and female earnings. The data in Table 3-1 are representative of the 1971-1980 decade. Probably more recent data would reduce this disparity between genders.
In order to obtain the present value of the SVOL for each of the cohorts, the discounted cumulative earnings for the life expectancy must be calculated. These calculations are listed in Table 3-2 for 7 percent and 3 percent discount rates as recommended in the NRC's Regulatory Analysis Guidelines. In order to simplify the calculations, the discounting was carried out at the center of five-year intervals, and the life expectancy was taken to be greater than 80 years.

For each cancer type, it was assumed that earnings stopped at the end of the latency period, and that the victim was disabled during the two year course of medical treatment. In the case of non-fatal cancer, it was assumed that the earnings resumed at the end of medical treatment. (Note the minor exceptions: in the case of skin cancer it was assumed that no loss of earnings occurred and in the case of benign thyroid nodules only one year loss of earnings was assumed).

The calculations used the risks for each cancer type listed in Table 2-1 of the preceding chapter.

In addition to the loss of human capital, each illness has associated direct costs for medical treatment. The medical costs for first and second year treatment were taken from Table A.17 of the HECOM Report [2] and normalized to 1990 dollars. Since medical treatment begins at the end of the latency period, the costs must be discounted to present value. The present value medical costs for each cancer type are listed in Table 3-3.

The contribution of each cancer type, $j$, to the value of the dollar per person-rem, $V_{j}$, is the product of risk, $R_{j}$, and the total cost (loss of earnings plus medical costs), $C_{j}$. The total value, $V$, of dollars per person-rem is the sum over all health effects. The detailed calculations for each of the cohorts are listed in Tables 3-4, 3-5, 3-6, and 3-7 respectively and summarized in Table 3-8. As can be seen, the 1990 \$/person-rem values yielded by this approach range from \$73/person-rem (30 year female cohort 
and $7 \%$ discount rate) to $\$ 288 /$ person-rem (20 year male cohort and 3\% discount rate).

\subsubsection{Sensitivity to Higher Estimates of SVOL}

As has been noted, the human capital method of estimating the statistical value of life based only on lost earnings, ignores a range of social losses that are difficult to quantify in monetary terms, e.g., pain and suffering, the anguish of loved ones, the loss of unpaid services that the average individual contributes to society, etc. It could be argued that when such imponderables are included, the statistical value of life would be much larger than the estimates listed in Table 3-2 based on lost earnings only. Therefore, we have explored the sensitivity of the dollars per person-rem to a wider range of the SVOL.

We have assumed present value SVOL's of one, three and ten million dollars and calculate the corresponding values of dollars per person-rem, $V$, using the same procedures as for the four cohorts in Tables 3-4 through 3-7. The results for an assumed three million dollar value of SVOL are listed in Table 3-9. The results for other SVOL values can be obtained approximately by prorating the three million dollar value. The present value of a one million dollar SVOL is about $\$ 770,000$ which differs only slightly from the present value of lost earnings for the 20- and 30-year old male cohorts when future earnings are discounted at a three percent rate. The present value for those two cohorts are $\$ 776,000$ and $\$ 798,000$, respectively; however, the bottom-line differs by a factor of about 1.5 because of the time distribution of earnings for the 20- and 30-year old cohorts. The calculations for the one million dollar SVOL are based on uniform earnings over a lifetime.

In Section 3.3, it will be seen that many of the SVOL estimates based on "willingness to pay" (WTP) approaches yield present values of SVOL in the range from one to ten million dollars. The data listed in Table 3-9 can be used to quickly estimate dollars per person-rem for any selected SVOL.

\subsection{Willingness-to-Pay Estimates}

\subsubsection{Methodology}

Estimates of individual willingness-to-pay are typically obtained through either the "revealed-preference" (or "implicit value") or the "questionnaire" (or "contingent market") approaches. The revealed preference approach involves estimating marginal incomes (or wage differentials) in cases where people trade-off income against risk of fatalities (or illnesses). Examples of the use of revealed preference include, the existence of higher wages for riskier jobs like working on oil rigs, the use of a more costly, heavier, but safer, car at a loss of fuel economy etc. This approach has the advantage of being based on real world situations where markets actually exist. However, it is usually quite difficult to isolate the income trade-off associated with only the particular safety issue under consideration. In addition, there is insufficient data on willingness-topay (WTP) for safety enhancements at nuclear power plants or other nuclear facilities. Thus one cannot rely totally on revealed preference from past cases for providing WTP estimates for the issue under consideration. Another limitation of the revealed preference approach is that, in most cases, it provides only information on what the aggregate (or average of aggregate) revealed preference would be. This limitation could be overcome by using a fairly disaggregated population set, and examining the individual revealed preference; however, this is usually not done because of procedural limitations.

The questionnaire ("contingent valuation") approach essentially involves asking a sample of the population of interest how much they would be willing to pay, or would require in compensation, for a decrease in the risk of a given type. The book by Mitchell and Carson [3] gives a detailed and comprehensive account of the contingent valuation method. The advantage of this method include its 
straightforwardness, and the ability to ask those directly affected by the problem what they consider to be the value of safety. The main difficulty in implementing the questionnaire approach is in ensuring that the questions are understandable in both scope and content.

In most surveys, it is clear that unless the questions are clear in content, the answers will either be incorrect or inconsistent. The issue of content can be managed by ensuring that the questions are intelligible, and that a training period ensues to familiarize the respondents about the particular problem that is under investigation. Also there has to be much care about how the questions are worded to ensure that they do not bias the response of the interviewees.

Even if the contents of the questions are understood clearly by the respondents, they may not be able to react rationally to the scope, i.e., the probability and magnitude of risk, of the problem. The problem of scope is very difficult to address, and there is a voluminous literature on this issue. The edited volume on Judgment Under Uncertainty by Kahneman, Slovic, and Tversky [4] contains a number of papers that deal with the problem of scope. For instance, the paper by Slovic, et al. [5] was the first one to summarize experimental evidence that shows that people regard everyday events such as driving an automobile to be much less risky than travelling in an airplane although statistical evidence shows this to be otherwise. Ross and Anderson [6] use "Attribution Theory" from the psychology literature, and Tversky and Kahneman [7] use "Availability" from the decision theoretic literature to provide explanations for the inconsistency in perceived risk. Fischoff [8] shows how past experience and hindsight affects how people estimate the probabilities of risky events.

In recent years, there have been a number of studies that try to understand how people react to low probability events. Ritov and Baron [9] show that ambiguity about the effects of vaccination leads to the reluctance of a large percentage of the U. S. population to get flu vaccines. Hogarth and Kunreuther [10] analyze how ambiguity in dealing with low probability events affects the availability of insurance for many situations. Many authors have also shown that people who react to risky events show "preference reversal", i.e., they may prefer alternative $A$ to alternative $B$, and $B$ to $C$, but instead of being transitive and preferring $A$ to $C$, they prefer $\mathrm{C}$ to $\mathrm{A}$. (See the papers by Grether and Plott [11] and Tversky, et al. [12])

The main problem is that most people show a great deal of ambiguity when dealing with low probability, high consequence events. Thus the response to seemingly simple questions may show a high degree of inconsistency. In addition, there is ample evidence from the public economics literature that people frequently respond to value elicitation questions by deliberately misrepresenting their true preferences. (See Chapter 6 of Mitchell and Carson [3]). There has also been additional theoretical work in recent years that show that people's behavior when subjected to risky situations does not follow the axioms which lead economists to believe that willingness-to-pay was the best method to elicit a person's maximum expected utility responses. (See Yates [13]).

All of these approaches eventually are aimed at assessing the statistical value-of-life for the purposes of decision-making, which is another controversial issue. Zeckhauser [14], for instance, contends that many would argue that life is priceless, and thus there is difficulty in coming to an agreement on how to value life. Indeed, the valuation of life involves technical, sociological, legal, philosophical, and political issues, not just economics.

In spite of all these problems with using the willingness-to-pay approach for obtaining the value that people (and society) place on improving safety, there is a general agreement among economists that such an approach is better than either using some ad-hoc (albeit purely "political") method to estimate 
the value of a statistical life, or the loss of output (present value of income foregone) approach.

\subsubsection{Willingness-To-Pay for Nuclear Safety}

As noted earlier, the benefit of a nuclear safety enhancement is the reduction of risk due to improved designs, more reliable systems, etc. and better procedures for operation, maintenance, and shut-down. The valuation of benefits is based on estimating monetary values for death and injury averted.

In estimating statistical value-of-life in the nuclear power industry, there is the notion that one could use a single measure across the board. In the case of nuclear facilities, a distinction can be made between two types of risk: public exposure risk versus risks that are experienced by workers in the nuclear industry. In the risk perception and communications literature, these would fall into the nonvoluntary versus voluntary risk categories. It is clear from the recent literature on risk perception and risk communication that people assess voluntary and nonvoluntary risk differently [15]. There is much greater concern among the public about risk situations that they do not control, such as nuclear power production, than risk situations that they voluntarily participate in such as driving an automobile.

Thus it is important in the assessment of nuclear power safety to consider public exposure risk and industry worker exposure risk separately. Public exposure risk is something that affects people who do not control the event or events leading to the exposure situation. Also the effects may occur over a long period of time. Conversely worker exposure risk is due to situations that are closer to things that can be controlled by those who are at risk. Further, these risks are much more immediate and may be more severe.
Since there has not been a comprehensive study based on the willingness-to-pay concept for mitigating these two types of risks in the nuclear industry, we have to use information from closely related situations. In the case of public exposure risk, we will use the numerous studies of radon exposure and radon reduction in private residences to evaluate willingness-to-pay. In addition, we will also summarize statistical value-of-life estimations from other related radiation risks such as using $\mathrm{x}$ rays for medical diagnostic purposes.

In the case of worker risk, there are a number of studies in "hazardous" industries such as mining in which WTP studies have been done. These studies will be the basis of our estimates for willingness-topay in reducing risk to workers in the nuclear industry. However, most people are faced with a number of voluntary risk situations in their day-today life. There are a number of studies that have estimated cost-of-life saved for everyday decisions, such as installing and using smoke alarms. Some of the pertinent data from these studies are summarized in the following sections.

\subsubsection{WTP for Reducing Public Exposure Risk}

\subsubsection{Radon}

In this section we provide data on risk reduction measures for radon which presents a radiological risk. The main purpose for reporting on willingnessto-pay estimates for reducing radon risk is that radon is the closest analogy to radiological risk due to nuclear power plants for which some numerical estimates are available. However, a number of caveats are in order. There is a continuing debate as to the magnitude of radon in U.S. homes, and the level of risk. For a number of reasons householders are reluctant to spend money to avert radon in the home. Thus, we are left with "expert judgment" estimates made by the Environmental 
Protection Agency (EPA) of how much it will cost to reduce the risk of radon, rather than true willingness-to-pay estimates that are obtained from either questionnaires or market behavior. It should be noted that performing a WTP survey was outside the scope of this project.

Radon gas is considered to be the second leading cause (after smoking) of lung cancer in the United States [16]. Much of the initial work on radon was on exposure of mine workers in the U.S. and Czechoslovakia (see [17] and [18]). Subsequently, there was the realization that the process of improving insulation of homes to conserve energy also trapped radon gas inside the buildings for much longer, resulting in added health effects of radiation. The UNSCEAR [19] Report estimated the average ${ }^{222} \mathrm{Rn}$ concentration to be 1 pico-curie per liter $(\mathrm{pCi} / \mathrm{L})$. Another measure for reporting radon concentration is "working level" (WL) which is the radiation level of $100 \mathrm{pCi} / \mathrm{L}$ of $\mathrm{Rn}$ in equilibrium with its daughters. Clearly since the duration of exposure is also an important indicator of whether or not the radiation would be a health hazard, the measure working level months (WLM) is also used. In a 1979 study of residences in New York and New Jersey, Breslin and George [20] found the average concentration levels to be $9.8 \mathrm{mWL}$ (milliworking level) in cellars, and $5.2 \mathrm{mWL}$ on first floors. Cohen [21] estimated that an extra 10,000 fatalities per year could be caused in the U.S. due to reduced ventilation.

A number of recent sample surveys have tried to assess the level of radon in U. S. residences. A study of single family residences by Nero, et al. [22] concluded that the data on radon levels were lognormal with a geometric mean of $0.9 \mathrm{pCi} / \mathrm{L}$ (with a standard deviation of $2.8 \mathrm{pCi} / \mathrm{L}$ ). The arithmetic mean corresponds to $1.5 \mathrm{pCi} / \mathrm{L}$. A more focussed study on Onondaga County, New York State showed a higher concentration: the median level was $5.1 \mathrm{pCi} / \mathrm{L}$, and $55 \%$ of the homes had basement radon levels of more than $4 \mathrm{pCi} / \mathrm{L}$ [23]. Because of geological factors, the level of radon in the northeastern United States is expected to be higher than that in most other regions of the country.

Radon abatement comes under the purview of the EPA. A paper by authors from the EPA states that "thousands of lung cancer deaths annually - perhaps 20,000 or more - may be attributable to radon" [24]. The estimates of risk due to inhalation of radon decay products in homes are extrapolated from epidemiological studies of underground miners. Based on published information up to 1986, Puskin and Nelson [24] used a linear relative risk model to make their radon risk projections. In calculating risks for indoor exposures to the general public, they made corrections, on an age specific basis, for differences in breathing rate and lung morphology, which reduced the projections by about $40 \%$. The central estimate of risk from constant lifetime exposure was $3.6 \times 10^{-4}$ fatal cancer/WLM. The range of their estimates is from $3.05 \times 10^{-4}$ to $4.2 \times 10^{-4}$ fatalities/WLM.

Another question relates to the total number of lung cancer deaths. Based on current exposure estimates, the EPA estimates that $15 \%$ of all lung cancer deaths in the U.S. are attributable to radon.

There is a school of thought that suggests that mitigation efforts should focus on houses with "highly elevated" radon, defined as those with radon levels above $10 \mathrm{pCi} / \mathrm{L}$. This will amount to about 600,000 houses out of 50 million. EPA considers any indoor air radon concentration of more than 4 $\mathrm{pCi} / \mathrm{L}$ to be unsafe, and advises mitigation. Reducing the indoor radon to $4 \mathrm{pCi} / \mathrm{L}$ will affect about 4.4 million houses, and avert 6,000 fatal cancers annually. The time period for taking action varies from a few years for concentrations of near 4 $\mathrm{pCi} / \mathrm{L}$, to months for near $20 \mathrm{pCi} / \mathrm{L}$, and weeks if above $200 \mathrm{pCi} / \mathrm{L}$ [24].

The EPA estimate is that each $\mathrm{pCi} / \mathrm{L}$ reduction in radon concentration in a single residence corresponds to roughly 0.01 lung cancer deaths averted 
over a 50-year period. Based on the Nero, et al. study [22], Puskin and Nelson [24] have estimated that if the households that had $7 \mathrm{pCi} / \mathrm{L}$ were targeted for remedial measures, about 2400 lung cancer deaths would be reduced annually.

The cost of mitigation would be $\$ 400$ to $\$ 5000$ in "up-front costs" plus annualized cost of $\$ 100-\$ 200$ in operations, monitoring, and maintenance, depending on the remedial action taken [24]. Given these figures, Puskin and Nelson have calculated the SVOL in the context of radon to be between $\$ 400,000$ and $\$ 7,000,000$. The average of these figures would be approximately $\$ 3.7$ million. Note that these figures are based on estimated costs, rather than on actual willingness-to-pay by households.

A related study by Russell and Gruber [25] examined the control of radon gas release from uranium mill tailings, and estimated the cost to industry of the most reasonable mitigation option to be approximately $\$ 1500$ million (1983\$) for 570 lives saved. The SVOL (in 1990 dollars) in this case is estimated to be $\$ 4.4$ million.

The studies on radon mitigation have been based on expert judgment as to the cost of the remediation plan. There is inadequate data to estimate statistical value of life based on willingness-to-pay obtained by either the revealed preference or the contingent claims (questionnaire) approach. The main reason for this is that there has not been sufficient radon mitigating investments by residences. In fact most experts who have surveyed the general public believe that the amount of money spent on radon mitigation is grossly lower than what is indicated by the level of risk due to the incidence of residential radon [26]. Weinstein, et al. [27] did a survey of 271 homeowners in New Jersey who had been informed about radon risk, and found that $87 \%$ of the respondents believed that their homes were likely to have average or less than average risk of radon. They elicited a number of reasons for this optimism and came to the conclusion that most people were apathetic to the problem of radon, which may not be true for the issues concerning the nuclear industry. The reasons for apathy were the fact that radon is naturally occurring with no identifiable villain, and that responsibility for action rested with the homeowner rather than the government or industry. It is also conceivable that the homeowners were not willing to spend money from their household budget to mitigate a risk that they may have thought to be virtually nonexistent.

Thus, there is not much data on actual willingnessto-pay for radon abatement at the household level base on either surveys or market behavior. Doing a survey on willingness-to-pay for risk reduction due to radon was outside the scope of this study. However, expert judgment on the cost of life saved provides a range of $\$ 3.7$ to $\$ 4.4$ million.

\subsubsection{Other Radiation Related Studies}

In a study done several years ago, Cohen [28] examined the cost per life saved (in 1978 dollars) of 58 different activities, including some radiationexposure related activities. The Cohen figures, escalated to 1990 dollars, are given in Table 3-10. These costs are based partially on market analysis (i.e., revealed preference), and partially on sessions with graduate students who were considered to be rational actors in the market. The estimates of a statistical life from the Cohen study [28] range from $\$ 9,000$ to $\$ 500$ million, with an average of $\$ 105.6$ million. Clearly, these figures are much higher than the average radon figures mentioned in the previous section.

Since the public's perception of its risk of exposure to nuclear power plants is partly based on the risk of getting cancer, it would also be illuminating to examine carcinogens as well. A recent study by Travis, Pack, and Fisher [29] examined 23 regulated and seven unregulated chemical carcinogens to determine cost per life saved. A related paper by Travis, et al. [30] provides 
figures on lifetime risk estimates for 131 chemicals. The purpose of both studies is to examine the level of risk that triggers regulatory action, and to estimate the cost of such action. The source of the data are notices of proposed and final regulations found in the Federal Register, and in published and unpublished support documents, all of which are in the public domain. The cost data were found for decisions made after the 1981 Executive Order 12291 which requires federal agencies to perform cost-benefit analysis if cost of mitigation was $\$ 100$ million or more. Travis, et al. [30] provide more details about the discount rates and the payback periods used in their study. The authors state that "the most surprising aspect of our study is the consistency found among federal agencies' methods in the use of cancer risk estimates for regulatory decisions" [30]. However, they found that the cost of life saved was not consistent and depended on the particular chemical under consideration.

Table 3-11 provides selected average figures from their study escalated to 1990 dollars. The range of the value of statistical life saved is from $\$ 0.12$ million to $\$ 208$ million and is quite large. The mean value of their study was $\$ 31.7$ million. It should be noted that these figures are based on cost estimates rather than willingness-to-pay. However, as the authors point out, both "the cancer risk and economic estimates are assumed to be upper bound or worst case." As such, they are good proxies for WTP estimates. Further, the authors also show that their estimates compare well with estimates of society's willingness to avoid death, such as Smith [31] and Morrall [32].

Thus, the statistical value-of-life estimated from carcinogenic chemicals is much higher than that estimated from expert judgment on the risk reduction from radon, but lower than the average figures from the Cohen [28] study. As we discussed earlier, most householders did not believe that their residences had a significant health risk due to radon. On the other hand, it is clear that the public considers the risk from other radiation related activities and chemical carcinogens to be significant. The main issue is whether the public perceives its risk from nuclear power plants to be in the same category as that from radon or from the radiation and cancer related activities. Given the reaction of the public to nuclear power in the United States, it seems clear that the more relevant risk measures are those that deal with radiation related activities and chemical carcinogen risk.

\subsubsection{WTP for Reducing Occupational Risk}

Recent estimates of the dollar value of avoided dose in the ALARA context, and the actual values being used in the nuclear industry, appear to be based on a trend toward acceptance of the "willingness to pay" approach to the valuation of detriment. A greater concern on the part of management and workers with radiation safety along with the additional costs of hiring and training crews to perform in high radiation environments and stricter limits on exposure have led to higher monetary values of avoided dose than the earlier estimates based on the approach of medical costs and the loss of potential earnings. Studies of Department of Energy contractor facilities by Gilchrist, et al. [33] in 1978 showed that values in a range of $\$ 1000$ to $\$ 10,000$ per person-rem were being used in various plants. Proceedings of a recent workshop on Occupational Dose Control and ALARA implementation at Nuclear Power Plants [34] revealed a range of values from $\$ 1000$ to $\$ 20,000$ per person-rem with most plants using about $\$ 5000$ per person-rem. A recent survey of 28 nuclear facility sites by S. Cohen and Associates for the NRC on the dollar value associated with occupational radiation exposure cited a range of values from $\$ 2500$ to $\$ 20,000$ per person-rem with an average value of $\$ 7000$ per person-rem.

The issue in the nuclear industry is the risk to workers in nuclear power plants and other nuclear facilities. The perceived risk to nuclear industry workers is similar to the perceived risk of working in 
hazardous industries, such as mining, oil rigs etc. Cohen [28] and Graham and Vaupel [35] have examined a number of cases involving hazardous occupations, and selected figures are given in Table 3-12. There have been a number of willingness-topay studies on occupational risk as well. In this context, the measure used is "revealed preference" where the willingness-to-accept wage differentials in order to compensate for a risky job is taken to indicate how people value the risk. Based on this concept, a number of authors have evaluated the statistical value of life. These figures are given in Table 3-13.

A number of organizations such as the Consumer Product Safety Commission, Environmental Protection Agency, the Health and Human Services Department, the National Highway Transportation Safety Agency, and the Occupational Safety and Health Agency have estimated the cost per life saved in a number of cases, other than direct employment. These figures are also indicative of how people perceive their day-to-day risk. Selected figures in 1990 dollars are given in Table 3-14 and 3-15.

Graham and Vaupel [35] show that OSHA figures that are directly related to hazardous occupations had a median value of $\$ 24$ million per life saved. The figures estimated by the other organizations ranged from about $\$ 100,000$ by the Consumer Product Safety Commission to $\$ 5.2$ million estimated by the EPA.

\subsubsection{WTP for Risk Prevention}

In addition to all the studies that have been cited to this point, there have been a number of studies that have examined the willingness-to-pay for reducing risk. The results of major studies are summarized in Table 3-16. Very few of these are related to radiological risk, although safety is the main concern. The mean value of these studies works out to $\$ 4.4$ million per life saved.

\subsubsection{Summary of SVOL based on WTP}

The information presented in sections 3.3 .3 to 3.3 .5 is summarized in Table 3-17. As Table 3-17 shows, the mean estimates of the statistical value of life from the various public exposure risk studies ranges from 3.7 to 31.7 million (1990) dollars. If the high value of 31.7 million dollars is omitted as an outlier the range is much narrower; from 3.7 to 4.4 million dollars. It is clear that cancers caused by toxic chemicals are a major focus of public concern simply because they are ubiquitous in both residences and the workplace. Thus, the amount of money spent on reducing the risks from chemical carcinogens is quite high. Conversely, the average cost of mitigation of the residential risk of radon is low because of the public perception that it is a "natural" hazard. However, radon is the only other radiological risk on which there are statistical value of life figures.

Table 3-17 also shows that the mean values of statistical life from the hazardous occupation risk studies range from a low of $\$ 3.1$ million to a high of $\$ 14$ million (1990 dollars).

It should be noted that many of the figures given in this section are based on cost estimates rather than willingness-to-pay values. There are a number of applications of the WTP approach to assess the value the public places on different goods; see for instance, the voluminous bibliography in the recent books by Mitchell and Carson [3] and Cummings, et al. [36]. Very few of these studies have looked at the willingness-to-pay to avoid environmental risk, and none of them have examined radiological risk. Thus, we are left with cost estimates that we used in this study which are the closest proxy to WTP.

Very recently, Baum, [57] has reviewed much of the data on SVOL provided in the tables above including both involuntary (public) risk and voluntary (occupational) risk reduction. Based on adjustments to the data made by Miller [58] to a wide range of studies in areas such as health-care actions, transportation safety, consumer products 
safety, wage-risk compensation, and WTP surveys, Baum considers that for public risk a range of SVOL from 1.4 million to 2.7 million (1990 dollars) is appropriate. For hazardous occupational risk, Baum reports values derived by Miller [58] which range from 1.2 million to 3.7 million dollars with a mean of 2.4 million, and by Viscusi [59] which range from 0.6 million to 16.2 million with a mean of 5.6 million dollars (all in 1990 dollars).

\subsection{References}

1. M. W. Jones-Lee, The Economics of Safety and Physical Risk, Basil Blackwell, London, 1989.

2. L. A. Nieves and J. J. Tawil, "The Economic Costs of Radiation-Induced Health Effects: Estimation and Simulation,"NUREG/CR-4811, PNL-6097, Pacific Northwest Laboratory, U.S. Nuclear Regulatory Commission, Washington, DC, August 1988.

3. R. C. Mitchell and R. T. Carson, Using Surveys to Value Public Goods: The Contingent Valuation Method, Resources for the Future, 1989.

4. D. Kahneman, P. Slovic, and A. Tversky, Judgment Under Uncertainty: Heuristics and Biases, Cambridge University Press, 1985.

5. P. Slovic, B. Fischoff, and S. Lichtenstein, "Facts Versus Fears: Understanding Perceived Risk," in Kahneman, et al. (eds.), Judgment Under Certainty: Heuristics and Biases, Cambridge University Press, pp. 463-492, 1985.

6. L. Ross and C. A. Anderson, "Shortcomings in the Attribution Process: On the Origins and Maintenance of Erroneous Social Assessments," in Kahneman, et al. (eds.), Judgment Under Uncertainty: Heuristics and Biases, Cambridge University Press, pp. 463492, 1985.
7. A. Tversky and D. Kahneman, "Availability: A Heuristic for Judging Frequency and Probability," in Kahneman, et al. (eds.), Judgment Under Uncertainty: Heuristics and Biases, Cambridge University Press, pp. 463492, 1985.

8. B. Fischhoff, "For those Condemned to Study the Past: Heuristics and Biases in Hindsight," in Kahneman, et al. (eds.), Judgment Under Uncertainty: Heuristics and Biases, Cambridge University Press, pp. 463-492, 1985.

9. I. Ritov and J. Baron, "Reluctance to Vaccinate: Omission Bias and Ambiguity," Journal of Behavioral Decision Making, Vol. 3, pp. 263-277, 1990.

10. R. Hogarth and $H$. Kunreuther, "Risk, Ambiguity, and Insurance," Journal of Risk and Uncertainty, Vol. 2, pp. 5-36, 1989.

11. D. Grether and C. Plott, "Economic Theory of Choice and the Preference Reversal Phenomenon," American Economic Review, Vol. 69, pp. 623-638, 1979.

12. A. Tversky, P. Slovic, and D. Kahneman, "The Causes of Preference Reversal," American Economic Review, pp. 204-217, March 1990.

13. F. Yates, Judgment and Decision Making, Englewood Cliff, NJ, Prentice-Hall, 1990.

14. R. Zeckhauser, "Procedures for Valuing Lives," Public Policy, Vol. 23, 1975.

15. V. T. Covello, P. Slovic, and D. von Winterfeldt, "Risk Communication: A Review of the Literature," unpublished paper, 1987.

16. National Research Council, Health Risks of Radon and Other Internally Deposited AlphaEmitters, National Academy Press, Washington, DC, 1988. 
3 The Monetary Costs of Latent Health Effects

17. D. C. Thomas, K. G. McNeill, and C Dougherty, "Estimates of Lifetime Lung Cancer Risks Resulting from Rn Progeny Exposures," Health Physics, Vol. 49, pp. 825$835,1988$.

18. J. Sevc, E. Kunz, I. Tomasek, V. Placek, and J. Horace, "Cancer in Man After Exposure to Rn Daughters," Health Physics, Vol. 54, pp. 27-37, 1988.

19. UNSCEAR, United Nations Scientific Committee on Effects of Atomic Radiation, Sources and Effects of Ionizing Radiation, New York, 1977.

20. A. J. Breslin and A. C. George, "Radon Sources, Distribution, and Exposures in ResidentialBuildings," Trans. American Nuclear Society, Vol. 33, p. 50, 1979.

21. B. L. Cohen, "Health Effects of Radon from Insulation of Buildings," Health Physics, Vol. 39, pp. 937-941, 1980.

22. A. V. Nero, M. B. Schwehr, W. W. Nazaroff, and K. L. Revzan, "Distribution of Airborne Radon-222 Concentration in U.S. Homes," Science, Vol. 234, pp. 992-999, 1986.

23. A. Mazur and G. S. Hall, "Effects of Social Influence and Measured Exposure Level on Response to Radon," Sociological Inquiry, Vol. 60, No. 3, pp. 274-284, 1990.

24. J. S. Puskin and C. B. Nelson, "EPA's Perspective on Risks from Residential Radon Exposure," Journal of the Air Pollution Control Association, Vol. 39, No. 7, pp. 915-919, 1989.

25. M. Russell and M. Gruber, "Risk Assessment in Environmental Policy Making," Science, Vol. 236, pp. 286-290, 1987.
26. V. K. Smith and F. R. Johnson, "How do Risk Perceptions Respond to Information? The Case of Radon," The Review of Economics and Statistics, Vol. 70, No. 1, pp. 1-8, 1988.

27. N. D. Weinstein, P. M. Sandman, and N. E. Roberts, "Determinants of Self-Protective Behavior: Home Radon Testing," Journal of Applied Social Psychology, Vol. 20, No. 10, pp. 783-801, 1990.

28. B. L. Cohen, "Society's Valuation of Life Saving in Radiation Protection and Other Contexts," Health Physics, Vol. 38, pp. 33-51, 1980.

29. C. C. Travis, S. R. Pack, and A. Fisher, "CostEffectiveness as a Factor in Cancer Risk Management," Environment International, Vol. 13, pp. 469-474, 1987.

30. C. C. Travis, S. A. Richter, E. A. C. Crouch, R. Wilson, and E. D. Klema, "Cancer Risk Management," Environmental Science and Technology, Vol. 21, No. 5, pp. 415-420, 1987.

31. R. S. Smith, "Compensating Wage Differentials and Public Policy: A Review," Industrial Labor Relations, Vol. 32, pp. 339-352, 1979.

32. J. F. Morrall, "A Review of the Record," Regulation, Nov.-Dec., 1986.

33. R. L. Gilchrist, et al., "Technical Guidelines for Maintaining Occupational Exposures As Low As Practicable," PNL-2663, Pacific Northwest Laboratories, August 1978.

34. J. W. Baum, et al., "Proceedings of the International Workshop on New Developments in Occupational Dose Control and ALARA Implementation at Nuclear Power Plants and Similar Facilities," NUREG/CR-0110, Brookhaven National Laboratory, 1989. 
35. J. D. Graham and J. W. Vaupel, "The Value of Life: What Difference Does It Make?" in R. Zeckhauser and Leebaert (eds.), What Role for Government, Duke Press Policy Studies, pp. 176-186, 1983.

36. R. G. Cummings, D. S. Brookshire, W. D. Schulze, Valuing Environmental Goods, Rowman and Allanheld, Totowa, NJ, 1986.

37. L. Needleman, "The Valuation of Changes in the Risk of Death by Those at Risk," The Manchester School, Vol. 48, pp. 229-254, 1980.

38. A. E. Dillingham, "The Injury Risk Structure of Occupations and Wages," Ph.D. dissertation, Cornell University, 1979.

39. R. J. Arnould and L. M. Nichols, "Wage-Risk Premiums and Workers Compensation: A Refinement of Estimates of Compensating Wage Differentials," Journal of Political Economy, Vol. 91, pp. 332-340, 1983.

40. R. Thaler and S. Rosen, "The Value of Saving a Life: Evidence from the Labor Market," in E. Terleckyj (ed.), Household Production and Consumption, NBER, New York.

41. V. K. Smith, "The Role of Site and Job Characteristics in Hedonic Wage Models," Journal of Urban Economics, Vol. 13, pp. 296321, 1983.

42. S. J. Melinek, "A Method of Evaluating Human Life for Economic Purposes," Accident Analysis and Prevention, Vol. 6, pp. 103-114, 1974.

43. C. Brown, "Equalizing Differences in the Labor Market," Quarterly Journal of Economics, Vol. 94, pp. 113-134, 1980.

44. A. Marin and G. Psacharopoulos, "The Reward for Risk in the Labor Market: Evidence from the United Kingdom and a Reconciliation with
Other Studies," Journal of Political Economy, Vol. 90, pp. 827-853, 1982.

45. R. S. Smith, The Occupational Safety and Health Act: Its Goals and Its Achievements, American Enterprise Institute, Washington, DC, 1976.

46. W. K. Viscusi, "Labor Market Valuations of Life and Limb: Empirical Evidence and Policy Implications," Public Policy, Vol. 26, pp. 359386, 1978.

47. P. Weiss, G. Meier, and S. Gerking, "The Economic Evaluation of Job Safety: A Methodological Survey and Some Estimates for Austria," Empirica-Austrian Economic Papers, Vol. 13, pp. 53-67, 1986.

48. C. Olson, "An Analysis of Wage Differentials Received by Workers on Dangerous Jobs," Journal of Human Resources, Vol. 16, pp. 167185, 1981.

49. M. W. Jones-Lee, The Value of Life: An Economic Analysis, University of Chicago Press, 1976.

50. R. Dardis, "The Value of Life: New Evidence from the Market Place," American Economic Review, Vol. 70, pp. 1077-1082, 1980.

51. P. M. Ippolito and R. A. Ippolito, "Measuring the Value of Life Saving from Consumer Reaction to New Information," Journal of Public Economics, Vol. 25, pp. 53-81, 1984.

52. J. P. Acton, "Evaluating Public Programs to Save Lives: The Case of Heart Attacks," Research Report R73-02, Rand Corporation, Santa Monica, CA, 1973.

53. M. Frankel, "Hazard Opportunity and the Valuation of Life," Mimeo, University of Illinois at Urbana-Champaign, 1979, quoted in [1] above. 
3 The Monetary Costs of Latent Health Effects

54. S. J. Melinek, S.K.D. Woolley, and R. Baldwin, "Analysis of a Questionnaire on Attitudes to Risk," Fire Research Note 962, Joint Fire Research Organization, Borehamwood, quoted in [1] above.

55. A. D. Maclean, The Value of Public Safety: Results of a Pilot-Scale Survey, U. K. Home Office Scientific Advisory Branch, 1979.

56. A. Fisher, L. G. Chestnut, and D. M. Violette, "The Value of Reducing Risks of Death: A Note on New Evidence," Journal of Policy Analysis and Management, Vol. 8, pp. 88-100, 1989.
57. J. W. Baum, "Value of Public Health and Safety Actions and Radiation Dose Avoided," NUREG/CR-6212， BNL-NUREG-52413, Brookhaven National Laboratory, May 1994.

58. T. R. Miller, "The Plausible Range for the Value of Life-Red Herrings Among the Mackerel,"Journal of Forensic Economics 3(3), 1990, pp. 17-39.

59. W. K. Viscusi, "Fatal Tradeoffs-Public and Private Responsibilities for Risk," Oxford University Press, 1992. 
3 The Monetary Costs of Latent Health Effects

Table 3-1 Mean Earnings of Employed Persons by Age and Gender (In 1990 Dollars)

\begin{tabular}{|c|c|c|}
\hline Age & Male & Female \\
\hline $20-24$ & 19166 & 11217 \\
\hline $25-29$ & 22596 & 13737 \\
\hline $30-34$ & 28550 & 14248 \\
\hline $35-39$ & 33359 & 14241 \\
\hline $40-44$ & 33968 & 14359 \\
\hline $45-49$ & 35189 & 14282 \\
\hline $50-54$ & 33931 & 14365 \\
\hline $55-59$ & 33188 & 14171 \\
\hline $60-64$ & 27647 & 13594 \\
\hline $65-69$ & 17640 & 9078 \\
\hline $70-74$ & 17004 & 8114 \\
\hline $75-79$ & 13507 & 7148 \\
\hline $80-$ over & 13507 & 7149 \\
\hline
\end{tabular}

Source: NUREG/CR-4811 [2], Table A.18 
3 The Monetary Costs of Latent Health Effects

Table 3-2 Discounted Five-Year Earnings and Cumulative Discounted Earnings to End of Life

\begin{tabular}{|c|c|c|c|c|c|c|}
\hline \multirow{2}{*}{$\begin{array}{c}\text { Age } \\
\text { (years) }\end{array}$} & \multicolumn{3}{|c|}{ 7\% Discount } & \multicolumn{3}{|c|}{ 3\% Discount } \\
\hline & $\begin{array}{c}\text { 5-Year } \\
\text { Discount } \\
\text { Factor }\end{array}$ & $\begin{array}{c}\text { Discounted } \\
\text { 5-Year } \\
\text { Earnings }\end{array}$ & $\begin{array}{l}\text { Earnings } \\
\text { to End } \\
\text { of Life }\end{array}$ & $\begin{array}{c}\text { 5-Year } \\
\text { Discount } \\
\text { Factor }\end{array}$ & $\begin{array}{c}\text { Discounted } \\
\text { 5-Year } \\
\text { Earnings }\end{array}$ & $\begin{array}{l}\text { Earnings } \\
\text { to End } \\
\text { of Life }\end{array}$ \\
\hline \multicolumn{7}{|c|}{ Age 20 Male Cohort } \\
\hline $20-24$ & 4.367 & 83,698 & 386,681 & 4.713 & 90,329 & 776,070 \\
\hline $25-29$ & 3.114 & 70,364 & 302,983 & 4.065 & 91,853 & 685,741 \\
\hline $30-34$ & 2.220 & 63,381 & 232,619 & 3.507 & 100,125 & 593,888 \\
\hline $35-39$ & 1.583 & 52,807 & 169,238 & 3.025 & 100,911 & 493,763 \\
\hline $40-44$ & 1.129 & 38,350 & 116,431 & 2.607 & 88,623 & 392,852 \\
\hline $45-49$ & 0.805 & 28,327 & 78,081 & 2.251 & 79,210 & 304,229 \\
\hline $50-54$ & 0.574 & 19,476 & 49,754 & 1.942 & 65,894 & 225,019 \\
\hline $55-59$ & 0.409 & 13,574 & 30,278 & 1.675 & 55,590 & 159,125 \\
\hline $60-64$ & 0.292 & 8,073 & 16,704 & 1.445 & 39,950 & 103,535 \\
\hline $65-69$ & 0.208 & 3,669 & 8,631 & 1.246 & 21,979 & 63,585 \\
\hline $70-74$ & 0.148 & 2,517 & 4,962 & 1.075 & 18,279 & 41,606 \\
\hline $75-79$ & 0.106 & 1,432 & 2,445 & 0.927 & 12,521 & 23,327 \\
\hline 80 -over & 0.075 & 1,013 & 1,013 & 0.800 & 10,806 & 10,806 \\
\hline \multicolumn{7}{|c|}{ Age 30 Male Cohort } \\
\hline $30-34$ & 4.367 & 124,678 & 457,552 & 4.713 & 134,556 & 798,123 \\
\hline $35-39$ & 3.114 & 103,880 & 332,874 & 4.065 & 135,604 & 663,567 \\
\hline $40-44$ & 2.220 & 75,409 & 228,994 & 3.507 & 119,126 & 527,963 \\
\hline $45-49$ & 1.583 & 55,704 & 153,585 & 3.025 & 106,447 & 408,837 \\
\hline $50-54$ & 1.129 & 38,308 & 97,881 & 2.609 & 88,526 & 302,390 \\
\hline $55-59$ & 0.805 & 26,716 & 59,573 & 2.251 & 74,706 & 213,864 \\
\hline $60-64$ & 0.574 & 15,869 & 32,857 & 1.942 & 53,690 & 139,158 \\
\hline $65-69$ & 0.409 & 7,215 & 16,988 & 1.675 & 29,547 & 85,468 \\
\hline $70-74$ & 0.292 & 4,965 & 9,773 & 1.445 & 24,571 & 55,921 \\
\hline $75-79$ & 0.208 & 2,809 & 4,808 & 1.246 & 16,830 & 31,350 \\
\hline 80 -over & 0.148 & 1,999 & 1,999 & 1.075 & 14,520 & 14,520 \\
\hline
\end{tabular}


3 The Monetary Costs of Latent Health Effects

Table 3-2 (continued)

\begin{tabular}{|c|c|c|c|c|c|c|}
\hline \multirow{2}{*}{$\begin{array}{c}\text { Age } \\
\text { (years) }\end{array}$} & \multicolumn{3}{|c|}{ 7\% Discount } & \multicolumn{3}{|c|}{ 3\% Discount } \\
\hline & $\begin{array}{l}\text { 5-Year } \\
\text { Discount } \\
\text { Factor }\end{array}$ & $\begin{array}{c}\text { Discounted } \\
\text { 5-Year } \\
\text { Earnings } \\
\end{array}$ & $\begin{array}{l}\text { Earnings } \\
\text { to End } \\
\text { of Life }\end{array}$ & $\begin{array}{c}\text { 5-Year } \\
\text { Discount } \\
\text { Factor }\end{array}$ & $\begin{array}{c}\text { Discounted } \\
\text { 5-Year } \\
\text { Earnings } \\
\end{array}$ & $\begin{array}{l}\text { Earnings } \\
\text { to End } \\
\text { of Life }\end{array}$ \\
\hline \multicolumn{7}{|c|}{ Age 20 Female Cohort } \\
\hline $20-24$ & 4.367 & 48,985 & 196,039 & 4.713 & 52,866 & 375,022 \\
\hline $25-29$ & 3.114 & 42,777 & 147,054 & 4.065 & 55,841 & 322,156 \\
\hline $30-34$ & 2.220 & 31,631 & 104,277 & 3.507 & 49,968 & 266,315 \\
\hline $35-39$ & 1.583 & 22,544 & 72,646 & 3.025 & 43,079 & 216,347 \\
\hline $40-44$ & 1.129 & 16,211 & 50,102 & 2.609 & 37,463 & 173,268 \\
\hline $45-49$ & 0.805 & 11,497 & 33,891 & 2.251 & 32,149 & 135,805 \\
\hline $50-54$ & 0.574 & 8,246 & 22,394 & 1.942 & 27,897 & 103,656 \\
\hline $55-59$ & 0.409 & 5,796 & 14,148 & 1.675 & 23,736 & 75,759 \\
\hline $60-64$ & 0.292 & 3,969 & 8,352 & 1.445 & 19,643 & 52,023 \\
\hline $65-69$ & 0.208 & 1,888 & 4,383 & 1.246 & 11,312 & 32,380 \\
\hline $70-74$ & 0.148 & 1,201 & 2,495 & 1.075 & 8,723 & 21,068 \\
\hline $75-79$ & 0.106 & 758 & 1,294 & 0.927 & 6,626 & 12,345 \\
\hline 80-over & 0.075 & 536 & 536 & 0.800 & 5,719 & 5,719 \\
\hline \multicolumn{7}{|c|}{ Age 30 Female Cohort } \\
\hline $30-34$ & 4.367 & 62,221 & 205,108 & 4.713 & 67,151 & 357,900 \\
\hline $35-39$ & 3.114 & 44,346 & 142,887 & 4.065 & 57,890 & 290,749 \\
\hline $40-44$ & 2.220 & 31,877 & 98,541 & 3.507 & 50,357 & 232,859 \\
\hline $45-49$ & 1.583 & 22,608 & 66,664 & 3.025 & 43,203 & 182,502 \\
\hline $50-54$ & 1.129 & 16,218 & 44,056 & 2.609 & 37,478 & 139,299 \\
\hline $55-59$ & 0.805 & 11,408 & 27,838 & 2.251 & 31,899 & 101,821 \\
\hline $60-64$ & 0.574 & 7,803 & 16,430 & 1.942 & 26,400 & 69,922 \\
\hline $65-69$ & 0.409 & 3,713 & 8,627 & 1.675 & 15,206 & 43,522 \\
\hline $70-74$ & 0.292 & 2,369 & 4,914 & 1.445 & 11,725 & 28,316 \\
\hline $75-79$ & 0.208 & 1,487 & 2,545 & 1.246 & 8,906 & 16,591 \\
\hline 80 -over & 0.148 & 1,058 & 1,058 & 1.075 & 7,685 & 7,685 \\
\hline
\end{tabular}


3 The Monetary Costs of Latent Health Effects

Table 3-3 Costs of Medical Treatment for Latent Health Effects

\begin{tabular}{||l|c|c|c||c|c||}
\hline \multirow{2}{*}{ Health Effect } & \multirow{2}{*}{$\begin{array}{c}\text { Latency } \\
\text { Period } \\
\text { (years) }\end{array}$} & $\begin{array}{c}\text { First Year } \\
\text { Costs }\end{array}$ & $\begin{array}{c}\text { Second Year } \\
\text { Costs }\end{array}$ & \multicolumn{2}{|c|}{$\begin{array}{c}\text { Present Value of } \\
\text { Two-Year Treatment }\end{array}$} \\
\cline { 3 - 6 } & & \multicolumn{2}{|c|}{$(\mathbf{1 9 9 0}$ Dollars) } & $\begin{array}{c}\text { 7\% Discount } \\
\text { Rate }\end{array}$ & $\begin{array}{c}\text { 3\% Discount } \\
\text { Rate }\end{array}$ \\
\hline \hline Leukemia & 2 & 13,716 & 17,374 & 26,151 & 28,831 \\
\hline Bone Cancer & 2 & 13,564 & 24,079 & 33,897 & 34,823 \\
\hline Breast Cancer & 10 & 11,125 & 6,401 & 8,692 & 12,899 \\
\hline Lung Cancer & 10 & 17,678 & 11,887 & 14,626 & 21,734 \\
\hline G-I Cancer & 10 & 20,269 & 9,144 & 14,640 & 21,682 \\
\hline Thyroid Cancer & 5 & 10,973 & 3,505 & 10,158 & 12,404 \\
\hline Benign Thyroid & 10 & 2,438 & 762 & 1,601 & 2,437 \\
\hline Skin Cancer & 10 & 2,591 & 0 & 1,316 & 2,005 \\
\hline Other Cancer & 10 & 14,935 & 12,649 & 13,595 & 20,245 \\
\hline
\end{tabular}


3 The Monetary Costs of Latent Health Effects

Table 3-4 Costs of Delayed Health Effects: 1990 Dollars/Person-Rem (20 Year Old Male Cohort)

\begin{tabular}{|c|c|c|c|c|c|c|c|c|c|}
\hline \multirow[t]{3}{*}{ Health Effect } & \multirow{3}{*}{$\begin{array}{c}\boldsymbol{R}_{\boldsymbol{j}} \\
\text { Risk } \\
\text { per } 1^{\mathbf{6}} \\
\text { Person-Rem }\end{array}$} & \multicolumn{4}{|c|}{ 7\% Discount Rate } & \multicolumn{4}{|c|}{ 3\% Discount Rate } \\
\hline & & $\begin{array}{c}\text { Medical } \\
\text { Costs }\end{array}$ & $\begin{array}{c}\text { Earnings } \\
\text { Loss }\end{array}$ & $C_{j}$ & $\begin{array}{c}V_{j} \\
\$ / \mathbf{P}-\mathbf{R}\end{array}$ & $\begin{array}{c}\text { Medical } \\
\text { Costs }\end{array}$ & $\begin{array}{c}\text { Earnings } \\
\text { Loss }\end{array}$ & $C_{j}$ & $\begin{array}{c}V_{j} \\
\$ / \mathbf{P}-\mathbf{R}\end{array}$ \\
\hline & & \multicolumn{4}{|c|}{1990 Dollars } & \multicolumn{4}{|c|}{1990 Dollars } \\
\hline \multicolumn{10}{|c|}{ Fatalities } \\
\hline Leukemia & 49 & 26151 & 319723 & 345874 & 16.95 & 28831 & 703807 & 732638 & 35.90 \\
\hline Bone Cancer & 4.5 & 33897 & 319723 & 353620 & 1.59 & 34823 & 703807 & 738630 & 3.32 \\
\hline Breast Cancer & - & - & 一 & - & - & - & - & - & - \\
\hline Lung Cancer & 78 & 14626 & 207267 & 221893 & 17.31 & 21734 & 553838 & 575572 & 44.89 \\
\hline GI Cancer & 168 & 14640 & 207267 & 221907 & 37.28 & 21682 & 553838 & 575520 & 96.69 \\
\hline Thyroid Cancer & 7.2 & 10158 & 274837 & 284995 & 2.05 & 12404 & 649000 & 661404 & 4.67 \\
\hline Benign Thyroid & - & 一 & 一 & 一 & 一 & - & - & 一 & - \\
\hline Skin Cancer & - & - & - & - & - & - & - & - & - \\
\hline Other Cancer & 138 & 13595 & 207267 & 220862 & 30.48 & 20245 & 553838 & 574083 & 79.80 \\
\hline \multicolumn{5}{|c|}{ Total V, Dollars Per Person-Rem } & 105.66 & & & & 265.27 \\
\hline \multicolumn{10}{|c|}{ Non-Fatalities } \\
\hline Leukemia & - & - & - & - & - & 一 & - & - & - \\
\hline Bone Cancer & - & $一$ & 一 & 一 & 一 & - & - & 一 & 一 \\
\hline Breast Cancer & - & - & 一 & - & - & - & - & 一 & 一 \\
\hline Lung Cancer & 8.5 & 17626 & 25352 & 39978 & 0.34 & 21734 & 40050 & 61784 & 0.53 \\
\hline GI Cancer & 119.5 & 14640 & 25352 & 39992 & 4.78 & 21682 & 40050 & 61732 & 7.38 \\
\hline Thyroid Cancer & 64.8 & 10158 & 28146 & 38304 & 2.48 & 12404 & 36741 & 49145 & 3.18 \\
\hline Benign Thyroid & 107.2 & 1601 & 12676 & 14277 & 1.53 & 2437 & 20025 & 22462 & 2.41 \\
\hline Skin Cancer & 444 & 1316 & 0 & 1316 & 0.58 & 2005 & 0 & 2005 & 0.89 \\
\hline Other Cancer & 138 & 13595 & 25352 & 38947 & 5.37 & 20245 & 40050 & 60295 & 8.32 \\
\hline \multicolumn{5}{|c|}{ Total V, Dollars Per Person-Rem } & 15.08 & & & & 22.71 \\
\hline \multicolumn{5}{|c|}{ Total Fatalities and Non-fatalities 1990 Dollars Per Person-Rem } & 120.74 & & & & 287.98 \\
\hline
\end{tabular}


3 The Monetary Costs of Latent Health Effects

Table 3-5 Costs of Delayed Health Effects: 1990 Dollars/Person-Rem (30 Year Old Male Cohort)

\begin{tabular}{|c|c|c|c|c|c|c|c|c|c|}
\hline \multirow{3}{*}{$\begin{array}{l}\text { Health } \\
\text { Effect }\end{array}$} & \multirow{3}{*}{$\begin{array}{c}R_{j} \\
\text { Risk } \\
\text { per } 10^{6} \\
\text { Person-Rem }\end{array}$} & \multicolumn{4}{|c|}{ 7\% Discount Rate } & \multicolumn{4}{|c|}{ 3\% Discount Rate } \\
\hline & & $\begin{array}{c}\text { Medical } \\
\text { Costs }\end{array}$ & $\begin{array}{l}\text { Earnings } \\
\text { Loss }\end{array}$ & $C_{j}$ & $\underset{\$ / \mathbf{P}-\mathbf{R}}{V_{j}}$ & $\begin{array}{c}\text { Medical } \\
\text { Costs }\end{array}$ & $\begin{array}{c}\text { Earnings } \\
\text { Loss }\end{array}$ & $C_{j}$ & $\begin{array}{c}V_{j} \\
\$ \mathbf{P}-\mathbf{R}\end{array}$ \\
\hline & & \multicolumn{4}{|c|}{1990 Dollars } & \multicolumn{4}{|c|}{1990 Dollars } \\
\hline \multicolumn{10}{|c|}{ Fatalities } \\
\hline Leukemia & 49 & 26151 & 357810 & 383961 & 18.81 & 28831 & 690478 & 719309 & 35.25 \\
\hline Bone Cancer & 4.5 & 33897 & 357810 & 391707 & 1.76 & 34823 & 690478 & 725301 & 3.26 \\
\hline Breast Cancer & - & - & - & - & - & - & - & - & - \\
\hline Lung Cancer & 78 & 14626 & 198830 & 213456 & 16.65 & 21734 & 480313 & 502047 & 39.16 \\
\hline GI Cancer & 168 & 14640 & 198830 & 213470 & 35.86 & 21682 & 480313 & 502005 & 84.34 \\
\hline Thyroid Cancer & 7.2 & 10158 & 291322 & 301480 & 2.17 & 12404 & 609325 & 621729 & 4.48 \\
\hline Benign Thyroid & - & - & - & - & - & - & - & - & - \\
\hline Skin Cancer & - & - & - & - & - & 一 & - & - & - \\
\hline Other Cancer & 138 & 13595 & 198830 & 212425 & 29.31 & 20245 & 480313 & 500558 & 69.08 \\
\hline \multicolumn{5}{|c|}{ Total V, Dollars per Person-Rem } & 104.56 & & & & 235.57 \\
\hline \multicolumn{10}{|c|}{ Non-Fatalities } \\
\hline Leukemia & - & - & - & - & - & - & 一 & - & - \\
\hline Bone Cancer & - & - & - & - & - & - & - & - & - \\
\hline Breast Cancer & - & - & 二 & - & 二 & - & - & - & - \\
\hline Lung Cancer & 8.5 & 17626 & 30164 & 44790 & 0.38 & 21734 & 47650 & 69384 & 0.59 \\
\hline GI Cancer & 119.5 & 14640 & 30164 & 44804 & 5.35 & 21682 & 47650 & 69332 & 8.29 \\
\hline Thyroid Cancer & 64.8 & 10158 & 41552 & 51710 & 3.35 & 12404 & 54242 & 66646 & 4.32 \\
\hline Benign Thyroid & 107.2 & 1601 & 15082 & 27758 & 2.98 & 2437 & 23825 & 26262 & 2.82 \\
\hline Skin Cancer & 444 & 1316 & 0 & 1316 & 0.58 & 2005 & $\mathbf{0}$ & 2005 & 0.89 \\
\hline Other Cancer & 138 & 13595 & 30164 & 43759 & 6.04 & 20245 & 19987 & 40232 & 5.55 \\
\hline \multicolumn{5}{|c|}{ Total V, Dollars per Person-Rem } & 18.68 & & & & 22.26 \\
\hline \multicolumn{5}{|c|}{ Total Fatalities and Non-Fatalities 1990 Dollars per Person-Rem } & 123.24 & & & & 257.83 \\
\hline
\end{tabular}


3 The Monetary Costs of Latent Health Effects

Table 3-6 Costs of Delayed Health Effects: 1990 Dollars/Person-Rem (20 Year Old Female Cohort)

\begin{tabular}{|c|c|c|c|c|c|c|c|c|c|}
\hline \multirow{3}{*}{$\begin{array}{l}\text { Health } \\
\text { Effect }\end{array}$} & \multirow{3}{*}{$\begin{array}{c}R_{j} \\
\text { Risk } \\
\text { per } 10^{6} \\
\text { Person-Rem }\end{array}$} & \multicolumn{4}{|c|}{ 7\% Discount Rate } & \multicolumn{4}{|c|}{ 3\% Discount Rate } \\
\hline & & $\begin{array}{c}\text { Medical } \\
\text { Costs }\end{array}$ & \begin{tabular}{|c} 
Earnings \\
Loss
\end{tabular} & $C_{j}$ & $\begin{array}{c}V_{j} \\
\mathbf{\$} / \mathbf{P}-\mathbf{R}\end{array}$ & $\begin{array}{c}\text { Medical } \\
\text { Costs }\end{array}$ & $\begin{array}{c}\text { Earnings } \\
\text { Loss }\end{array}$ & $C_{j}$ & $\begin{array}{c}V_{J} \\
\text { \$/P-R }\end{array}$ \\
\hline & & \multicolumn{4}{|c|}{1990 Dollars } & \multicolumn{4}{|c|}{1990 Dollars } \\
\hline \multicolumn{10}{|c|}{ Fatalities } \\
\hline Leukemia & 49 & 26151 & 156851 & 183002 & 8.97 & 28831 & 332729 & 361560 & 17.72 \\
\hline Bone Cancer & 4.5 & 33897 & 156851 & 190748 & 0.86 & 34823 & 332729 & 367552 & 1.65 \\
\hline Breast Cancer & 108 & 8692 & 91625 & 100317 & 10.83 & 12899 & 243628 & 259227 & 28.00 \\
\hline Lung Cancer & 78 & 14626 & 91625 & 106251 & 8.29 & 21734 & 246328 & 268062 & 20.91 \\
\hline GI Cancer & 168 & 14640 & 91625 & 106265 & 17.85 & 21862 & 246328 & 268010 & 45.03 \\
\hline Thyroid Cancer & 7.2 & 10158 & 129943 & 140101 & 1.01 & 12404 & 299820 & 312224 & 2.25 \\
\hline Benign Thyroid & - & 一 & - & - & - & - & - & - & - \\
\hline Skin Cancer & - & 一 & - & - & - & - & - & - & - \\
\hline Other Cancer & 138 & 13595 & 91625 & 105220 & 14.52 & 20245 & 246328 & 266573 & 36.79 \\
\hline \multicolumn{5}{|c|}{ Total V, Dollars per Person-Rem } & 62.33 & & & & 152.35 \\
\hline \multicolumn{10}{|c|}{ Non-Fatalities } \\
\hline Leukemia & - & - & - & - & - & - & - & - & - \\
\hline Bone Cancer & - & - & - & - & - & - & - & - & - \\
\hline Breast Cancer & 210 & 8692 & 12652 & 21344 & 4.48 & 12899 & 19987 & 32881 & 6.91 \\
\hline Lung Cancer & 8.5 & 17626 & 12652 & 27278 & 0.23 & 21734 & 19987 & 41721 & 0.35 \\
\hline GI Cancer & 119.5 & 14640 & 12652 & 27292 & 3.26 & 21682 & 19987 & 41669 & 4.98 \\
\hline Thyroid Cancer & 64.8 & 10158 & 17111 & 27269 & 1.77 & 12404 & 22336 & 34740 & 2.25 \\
\hline Benign Thyroid & 107.2 & 1601 & 6326 & 7927 & 0.85 & 2437 & 9994 & 12431 & 1.33 \\
\hline Skin Cancer & 444 & 1316 & 0 & 1316 & 0.58 & 2005 & 0 & 2005 & 0.89 \\
\hline Other Cancer & 138 & 13595 & 12652 & 26247 & 3.62 & 20245 & 19987 & 40232 & 5.55 \\
\hline \multicolumn{5}{|c|}{ Total V, Dollars Per Person-Rem } & 14.71 & & & & 22.26 \\
\hline \multicolumn{5}{|c|}{ Total Fatalities and Non-Fatalities 1990 Dollars per Person-Rem } & 77.04 & & & & 174.61 \\
\hline
\end{tabular}


3 The Monetary Costs of Latent Health Effects

Table 3-7 Costs of Delayed Health Effects: 1990 Dollars/Person-Rem (30 Year Old Female Cohort)

\begin{tabular}{|c|c|c|c|c|c|c|c|c|c|}
\hline \multirow{3}{*}{$\begin{array}{l}\text { Health } \\
\text { Effect }\end{array}$} & \multirow{3}{*}{$\begin{array}{c}\boldsymbol{R}_{\boldsymbol{j}} \\
\text { Risk } \\
\text { per } \mathbf{1 0}^{\mathbf{6}} \\
\text { Person-Rem }\end{array}$} & \multicolumn{4}{|c|}{ 7\% Discount Rate } & \multicolumn{4}{|c|}{ 3\% Discount Rate } \\
\hline & & $\begin{array}{c}\text { Medical } \\
\text { Costs }\end{array}$ & $\begin{array}{c}\text { Earnings } \\
\text { Loss }\end{array}$ & $C_{j}$ & $\begin{array}{c}V_{j} \\
\$ / \mathbf{P}-\mathbf{R}\end{array}$ & $\begin{array}{c}\text { Medical } \\
\text { Costs }\end{array}$ & $\begin{array}{c}\text { Earnings } \\
\text { Loss }\end{array}$ & $C_{j}$ & $\begin{array}{c}V_{j} \\
\$ / \mathbf{P}-\mathbf{R}\end{array}$ \\
\hline & & \multicolumn{4}{|c|}{1990 Dollars } & \multicolumn{4}{|c|}{1990 Dollars } \\
\hline \multicolumn{10}{|c|}{ Fatalities } \\
\hline Leukemia & 49 & 26151 & 155331 & 181482 & 8.89 & 28831 & 304179 & 333010 & 16.32 \\
\hline Bone Cancer & 4.5 & 33897 & 155331 & 189228 & 0.85 & 34823 & 304179 & 339002 & 1.53 \\
\hline Breast Cancer & 108 & 8692 & 85790 & 94482 & 10.20 & 12899 & 212716 & 225615 & 24.37 \\
\hline Lung Cancer & 78 & 14626 & 85790 & 100416 & 7.83 & 21734 & 212716 & 234450 & 18.29 \\
\hline GI Cancer & 168 & 14640 & 85790 & 100430 & 16.87 & 21682 & 212716 & 234398 & 39.38 \\
\hline Thyroid Cancer & 7.2 & 10158 & 125149 & 135307 & 0.97 & 12404 & 267593 & 279997 & 2.02 \\
\hline Benign Thyroid & 一 & - & - & - & - & - & - & - & - \\
\hline Skin Cancer & - & - & - & 一 & - & 一 & - & - & - \\
\hline Other Cancer & 138 & 13595 & 85790 & 99385 & 13.72 & 20245 & 212716 & 232961 & 32.15 \\
\hline \multicolumn{5}{|c|}{ Total V, Dollars per Person-Rem } & 58.33 & & & & 134.06 \\
\hline \multicolumn{10}{|c|}{ Non-Fatalities } \\
\hline Leukemia & 一 & - & - & - & 一 & - & - & - & - \\
\hline Bone Cancer & - & - & - & - & - & - & - & - & - \\
\hline Breast Cancer & 210 & 8692 & 12751 & 21443 & 4.50 & 12899 & 20143 & 33042 & 6.94 \\
\hline Lung Cancer & 8.5 & 17626 & 12751 & 27377 & 0.23 & 21734 & 20143 & 41877 & 0.36 \\
\hline GI Cancer & 119.5 & 14640 & 12751 & 27391 & 3.27 & 21682 & 20143 & 41825 & 5.00 \\
\hline Thyroid Cancer & 64.8 & 10158 & 17738 & 27896 & 1.81 & 12404 & 23156 & 35560 & 2.30 \\
\hline Benign Thyroid & 107.2 & 1601 & 6375 & 7976 & 0.86 & 2437 & 10071 & 12508 & 1.34 \\
\hline Skin Cancer & 444 & 1316 & 0 & 1316 & 0.58 & 2005 & 0 & 2005 & 0.89 \\
\hline Other Cancer & 138 & 13595 & 12751 & 26346 & 3.64 & 20245 & 20143 & 40388 & 5.57 \\
\hline \multicolumn{5}{|c|}{ Total V, Dollars per Person-Rem } & 14.89 & & & & 22.43 \\
\hline \multicolumn{5}{|c|}{ Total Fatalities and Non-Fatalities 1990 Dollars per Person-Rem } & 73.22 & & & & 156.49 \\
\hline
\end{tabular}


3 The Monetary Costs of Latent Health Effects

Table 3-8 Estimated Values of Averted Radiation Dose Based on Earnings Loss for Different Cohorts

\begin{tabular}{||l|c|c|c|c|c|c||}
\hline \multirow{2}{*}{ Cohort/SVOL } & \multicolumn{5}{|c|}{1990 Dollars per Person-Rem } \\
\cline { 2 - 8 } & \multicolumn{2}{|c|}{ 7\% Discount Rate } & \multicolumn{3}{c||}{ 3\% Discount Rate } \\
\cline { 2 - 8 } & $\begin{array}{c}\text { Non-Fatal } \\
\text { Cancer }\end{array}$ & $\begin{array}{c}\text { Fatal } \\
\text { Cancer }\end{array}$ & Total & $\begin{array}{c}\text { Non-Fatal } \\
\text { Cancer }\end{array}$ & $\begin{array}{c}\text { Fatal } \\
\text { Cancer }\end{array}$ & Total \\
\hline \hline Human Capital Approach: & & & & & & \\
\hline 20 Year Old Male & 15 & 106 & 121 & 23 & 265 & 288 \\
\hline 20 Year Old Female & 15 & 62 & 77 & 22 & 152 & 174 \\
\hline 30 Year Old Male & 19 & 105 & 124 & 26 & 236 & 262 \\
\hline 30 Year Old Female & 15 & 58 & 73 & 22 & 134 & 156 \\
\hline
\end{tabular}


3 The Monetary Costs of Latent Health Effects

Table 3-9 Costs of Delayed Health Effects: 1990 Dollars per Person-Rem (Based on Assumed SVOL $=\$ 3$ Million)

\begin{tabular}{|c|c|c|c|c|c|c|c|c|c|}
\hline \multirow[t]{3}{*}{ Health Effect } & \multirow{3}{*}{$\begin{array}{c}R_{j} \\
\text { Risk } \\
\text { per 10 } \\
\text { Person-Rem }\end{array}$} & \multicolumn{4}{|c|}{ 7\% Discount Rate } & \multicolumn{4}{|c|}{ 3\% Discount Rate } \\
\hline & & $\begin{array}{c}\text { Medical } \\
\text { Costs }\end{array}$ & $\begin{array}{c}\text { Loss of } \\
\text { SVOL }\end{array}$ & $C_{j}$ & $\begin{array}{c}V_{j} \\
\$ / \mathbf{P}-\mathbf{R}\end{array}$ & $\begin{array}{c}\text { Medical } \\
\text { Costs }\end{array}$ & $\begin{array}{c}\text { Loss of } \\
\text { SvOL }\end{array}$ & $\mathbf{C}_{\mathbf{J}}$ & $\begin{array}{c}\mathbf{V}_{\mathbf{j}} \\
\mathbf{S - P}-\mathbf{R}\end{array}$ \\
\hline & & \multicolumn{4}{|c|}{1990 Millions of dollars } & \multicolumn{4}{|c|}{1990 Millions of Dollars } \\
\hline \multicolumn{10}{|c|}{ Fatalities } \\
\hline Leukemia & 49 & 0.026 & 2.620 & 2.646 & 129 & 0.029 & 2.829 & 2.858 & 139 \\
\hline Bone Cancer & 4.5 & 0.034 & 2.620 & 2.654 & 12 & 0.035 & 2.829 & 2.864 & 13 \\
\hline Breast Cancer & $54^{\mathrm{a}}$ & 0.009 & 1.520 & 1.529 & 83 & 0.013 & 2.232 & 2.245 & 121 \\
\hline Lung Cancer & 78 & 0.015 & 1.520 & 1.535 & 119 & 0.022 & 2.232 & 2.254 & 175 \\
\hline GI Cancer & 168 & 0.015 & 1.520 & 1.535 & 257 & 0.022 & 2.232 & 2.254 & 376 \\
\hline Thyroid Cancer & 7.2 & 0.010 & 2.140 & 2.150 & 15 & 0.012 & 2.589 & 2.601 & 19 \\
\hline Benign Thyroid & - & - & - & - & - & - & - & - & - \\
\hline Skin Cancer & 一 & 一 & - & - & - & - & - & - & - \\
\hline Other Cancer & 138 & 0.014 & 1.520 & 1.534 & 211 & 0.020 & 2.232 & 2.252 & 309 \\
\hline \multicolumn{5}{|c|}{ Total V, Dollars Per Person-Rem } & 826 & & & & 1152 \\
\hline \multicolumn{10}{|c|}{ Non-Fatalities } \\
\hline Leukemia & - & - & - & - & - & - & - & - & - \\
\hline Bone Cancer & - & - & - & - & - & - & - & - & - \\
\hline Breast Cancer & $105^{\mathrm{a}}$ & 0.009 & 0.192 & 0.201 & 20 & 0.013 & 0.129 & 0.142 & 14 \\
\hline Lung Cancer & 8.5 & 0.018 & 0.192 & 0.210 & 2 & 0.022 & 0.129 & 0.151 & 1 \\
\hline GI Cancer & 119.5 & 0.015 & 0.192 & 0.207 & 23 & 0.022 & 0.129 & 0.151 & 16 \\
\hline Thyroid Cancer & 64.8 & 0.010 & 0.270 & 0.280 & 20 & 0.012 & 0.150 & 0.162 & 10 \\
\hline Benign Thyroid & 107.2 & 0.002 & 0.009 & 0.011 & 11 & 0.002 & 0.066 & 0.068 & 7 \\
\hline Skin Cancer & 444 & 0.001 & - & 0.001 & 0 & 0.002 & - & 0.002 & 0 \\
\hline Other Cancer & 138 & 0.014 & 0.192 & 0.206 & 27 & 0.020 & 0.129 & 0.149 & 19 \\
\hline \multicolumn{5}{|c|}{ Total V, Dollars Per Person-Rem } & 103 & & & & 67 \\
\hline \multicolumn{5}{|c|}{ Total Fatalities and Non-fatalities 1990 Dollars Per Person-Rem } & 929 & & & & 1219 \\
\hline
\end{tabular}

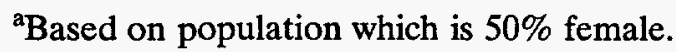


3 The Monetary Costs of Latent Health Effects

Table 3-10 Statistical Value-of-Life for Radiation Related Activities (Based on Expert Judgment)

\begin{tabular}{|l|c|}
\hline \multicolumn{1}{|c|}{ ITEM } & Cost Per Life Saved (\$1990) \\
\hline \hline Radium in Drinking Water & $6,250,000$ \\
\hline Medical X-ray Equipment & 9,000 \\
\hline Defense High-Level Waste & $500,000,000$ \\
\hline Civilian High-Level Waste & $45,000,000$ \\
\hline Radwaste Practice & $250,000,000$ \\
\hline
\end{tabular}

Source: Cohen [28] 
3 The Monetary Costs of Latent Health Effects

Table 3-11 Statistical Value-of-Life from Reduction of Risk Due to Carcinogenic Chemicals (Based on Expert Judgment)

\begin{tabular}{||l|c|}
\hline \multicolumn{1}{|c|}{ Chemical } & Cost Per Life-Saved (\$1990) \\
\hline \hline Products & \\
\hline Lead & $1,880,000$ \\
\hline Asbestos & $4,175,000$ \\
\hline Vinyl Chloride & $16,150,000$ \\
\hline Formaldehyde & $2,850,000$ \\
\hline Trihalomethane & 240,000 \\
\hline Butadiene & 200,000 \\
\hline Cadmium & $1,200,000$ \\
\hline Chromium & 40,000 \\
\hline Chlorobenzilate & $25,000,000$ \\
\hline Ethylene Oxide & $4,730,000$ \\
\hline Benzene (Pure) & $199,000,000$ \\
\hline Processes & \\
\hline Soil Fumigation & $\mathbf{8 7 0 , 0 0 0}$ \\
\hline Quarantine Fumigation & 120,000 \\
\hline Glass Manufacturing & $105,000,000$ \\
\hline Low-Arsenic Copper Smelting & $208,000,000$ \\
\hline High-Arsenic Copper Smelting & $2,080,000$ \\
\hline MEAN & $31,700,00$ \\
\hline
\end{tabular}

Source: Travis, et al. [30] 
3 The Monetary Costs of Latent Health Effects

Table 3-12 Occupational Related Statistical Value-of-Life

(Based on Expert Judgment)

\begin{tabular}{||l|c||}
\hline \multicolumn{1}{|c|}{ Item } & Value of Life (\$1990) \\
\hline \hline Coal Mine Safety & $55,000,000$ \\
\hline Other Mine Safety & $85,000,000$ \\
\hline Coke Fume Standards & $11,250,000$ \\
\hline Air Force Pilot Safety & $5,000,000$ \\
\hline Civilian Aircraft & $3,000,000$ \\
\hline \multicolumn{2}{|c|}{ Source: Cohen [28] } \\
\hline 1983 OSHA Standards & $24,000,000$ \\
\hline 1.0 ppm Ambient Air in Workplace & $57,200,000$ \\
\hline 0.2 ppm Standard & $336,000,000$ \\
\hline \multicolumn{2}{|c|}{ Source: Graham and Vaupel [35] } \\
\hline
\end{tabular}


3 The Monetary Costs of Latent Health Effects

Table 3-13 Occupational Statistical Value of Life

(Based on Willingness-to-Accept Wage Differentials)

\begin{tabular}{||l|l|c||}
\hline \multicolumn{1}{|c|}{ Author } & Study Year & Value of Life (\$1990) \\
\hline \hline Needleman [37] & 1968 (UK) & $\$ 250,000$ \\
\hline Dillingham [38] & 1970 (USA) & $\$ 760,000$ \\
\hline Arnould [39] & 1970 (USA) & $\$ 780,000$ \\
\hline Thaler-Rosen [40] & 1967 (USA) & $\$ 800,000$ \\
\hline Smith, V. K. [41] & 1978 (USA) & $\$ 1,100,000$ \\
\hline Melinek [42] & 1971 (UK) & $\$ 1,900,000$ \\
\hline Brown [43] & 1967 (USA) & $\$ 2,400,000$ \\
\hline Marin [44] & 1975 (UK) & $\$ 3,600,000$ \\
\hline Smith, R. S. [45] & 1976 (USA) & $\$ 4,700,000$ \\
\hline Viscusi [46] & 1969 (USA) & $\$ 4,900,000$ \\
\hline Weiss [47] & 1981 (Austria) & $\$ 6,200,000$ \\
\hline Olson [48] & 1973 (USA) & $\$ 10,000,000$ \\
\hline & Mean & $\approx \$ 3,100,000$ \\
\hline & Median & $\approx \$ 2,100,000$ \\
\hline
\end{tabular}


3 The Monetary Costs of Latent Health Effects

Table 3-14 Value of Life in Transportation Risk Abatement (Based on Revealed Preference)

\begin{tabular}{||l|c|}
\hline \multicolumn{1}{|c|}{ Item } & Value of Life (\$1990) \\
\hline \hline Automobile Safety & \\
\hline Steering Column Improvement & 250,000 \\
\hline Driver Side Airbags & 800,000 \\
\hline Passive Seatbelts & 625,000 \\
\hline Tire Inspection & $1,000,000$ \\
\hline Skid Resistance & 105,000 \\
\hline Traffic Safety & \\
\hline Highway Maintenance & 50,000 \\
\hline Regulatory and Warning Signs & 85,000 \\
\hline Guardrail Improvements & 85,000 \\
\hline Wrong Way Entry Avoidance & 125,000 \\
\hline Impact Absorbing Roadside Devices & 270,000 \\
\hline Median Barrier Improvement & 570,000 \\
\hline Clear Roadside Recovery Area & 710,000 \\
\hline
\end{tabular}

Source: Cohen [28] 
Table 3-15 Cost per Statistical Life from Day-to-Day Products

(Based on Expert Judgment)

\begin{tabular}{|l|c|}
\hline \multicolumn{1}{|c|}{ Item } & Cost Per Life (\$1990) \\
\hline \hline Smoke Detectors in Bedrooms Only & 79,500 \\
\hline Mandatory Smoke Detectors & 119,000 \\
\hline Alcohol Safety Action Projects & 162,000 \\
\hline Diet Program & 203,000 \\
\hline Clothing Flammability Standard & 795,000 \\
\hline Safer Fuel Tanks and Boilers & $1,360,000$ \\
\hline \multicolumn{1}{|c|}{ Source for all the above: } & Graham and Vaupel [35] \\
\hline Airline Safety (Jones-Lee, [49]) & $29,150,000$ \\
\hline $\begin{array}{l}\text { Domestic Smoke Detectors } \\
\text { (Dardis, [50]) }\end{array}$ & 775,000 \\
\hline Cigarette Smokers (Ippolito, [51]) & 934,000 \\
\hline
\end{tabular}

Source: Various sources as indicated in table. 
3 The Monetary Costs of Latent Health Effects

Table 3-16 Willingness-to-Pay for Nonradiological Risk Reduction (Population Surveys)

\begin{tabular}{||l|l|c||}
\hline \multicolumn{1}{|c|}{ Author } & \multicolumn{1}{|c|}{ Nature of Study } & Value of Life (\$1990) \\
\hline \hline Acton [52] & Heart Attack Ambulance & $\$ 93,000$ \\
\hline Frankel [53] & Large Airline Risk & $\$ 95,000$ \\
\hline Melinek [54] & Hypothetical Safe Cigarette & $\$ 150,000$ \\
\hline Melinek [54] & Domestic Fire Safety & $\$ 480,000$ \\
\hline Jones-Lee [1] & Transport Safety & $\$ 3,500,00$ \\
\hline Maclean [55] & Domestic Fire Safety & $\$ 4,700,000$ \\
\hline Frankel [53] & Small Airline Risk $\approx 22,000,000$ \\
\hline & $\begin{array}{l}\text { Mean } \\
\text { Median }\end{array}$ & \\
\hline
\end{tabular}


3 The Monetary Costs of Latent Health Effects

Table 3-17 Summary Statistics on the Value of Statistical Life

(Million 1990 Dollars)

\begin{tabular}{|c|c|c|c|}
\hline Category of Analysis & Mean Value & Low & High \\
\hline \multicolumn{4}{|l|}{ Public Exposure Risk } \\
\hline $\begin{array}{l}\text { Radon (residential) } \\
\text { (Puskin \& Nelson, [24]) }\end{array}$ & 3.7 & 0.4 & 7.0 \\
\hline $\begin{array}{l}\text { Radon (uranium mines) } \\
\text { (Russell \& Gruber, [25]) }\end{array}$ & 4.4 & - & - \\
\hline $\begin{array}{l}\text { Chemical Carcinogens } \\
\text { (Travis, et al., [30]) }\end{array}$ & 31.7 & 0.12 & 208.0 \\
\hline $\begin{array}{l}\text { Nonradiological Risk } \\
\text { (Table 3-13) }\end{array}$ & 4.4 & 0.93 & 22.0 \\
\hline \multicolumn{4}{|l|}{ Hazardous Occupation Risk } \\
\hline $\begin{array}{l}\text { Use in Nuclear Power Plants } \\
\text { (Baum, [34]) }\end{array}$ & 14.0 & 2.0 & 40.0 \\
\hline Graham and Vaupel [35] & 14.3 & 0.03 & 336.0 \\
\hline Fisher, et al. [56] & 5.8 & 0.54 & 10.1 \\
\hline Wage Differential (Table 3-10) & 3.1 & 0.25 & 10.0 \\
\hline
\end{tabular}




\subsection{OFFSITE AND ONSITE DAMAGE COSTS}

\subsection{Offsite Consequences}

Offsite consequences of accidents at U.S. nuclear power plants have been modeled by consequence codes beginning with the CRAC (Calculation of Reactor Accident Consequences)code developed for the Reactor Safety Study [1]. The CRAC code was later upgraded to the CRAC2 code [2]; this has now been replaced by the MELCOR Accident Consequence Code System (MACCS) [3]. The MACCS code has been developed at Sandia National Laboratories (SNL) for performing sitespecific consequence calculations for the NUREG1150 [4] program.

The consequence codes are used to calculate:

- Downwind transport, dispersion, and deposition of the radioactive material,

- Radiation doses received by exposed populations,

- Mitigation of doses by emergency response actions,

- Early fatalities and injuries (expected to occur within one year of an accident),

- Latent cancer fatalities,

- Total population dose (person-rem), and

- Offsite costs.

The principal differences from CRAC2 are that MACCS uses a multipuff atmospheric dispersion model and has a new radiological health effects model described in NUREG/CR-4214 [5]. In addition, the economic data sets in MACCS contain more recent information, which can be used to evaluate the offsite costs of a reactor accident within the continental United States.

The offsite costs include costs of emergency actions, disposal of contaminated foods, cleanup and interdiction of contaminated land and structures, and long-term relocation of people and condemnation of land and property. The costs depend on the severity of the release, site-specific features (land and property values, etc.), and the mitigative actions taken during and after the accident. The actions taken are input to MACCS by the user. For a particular plant, a site data file is constructed using land use and economic data in the Final Safety Analysis Reports (FSARs) and the latest U.S. statistical abstracts. The basis of the economic models used to estimate offsite costs are described in NUREG/CR-3673 [6] and their application is discussed in NUREG/CR-4691 [3].

In the early stages of an accident, costs are associated with emergency evacuation and relocation. These costs depend on the number of people affected and the duration of the emergency evacuation/relocation period. The evacuated individuals are allowed to return only if the projected groundshine dose does not exceed a preset criterion for the duration of the emergency phase. Otherwise, people are relocated for at least the duration of the phase which can range from one day to one week.

Following the emergency phase, there can be an intermediate period of up to one year during which people will remain relocated, depending upon projected doses from the groundshine and resuspension inhalation pathways. In the long-term phase, decontamination or interdiction decisions are made for farm and non-farm areas. Three successively higher levels of decontamination each associated with respectively higher costs can be modeled by MACCS. If the decontamination efforts plus natural decay over a period cannot reduce the projected long-term doses below a (user-specified) value or the cost of decontamination exceeds the value of the farmland or non-farm property, then the property or land is condemned. The discounted value of the 
condemned land (or property) is added to the other offsite costs.

MACCS takes into account costs associated with depreciation of property values in contaminated areas as well as losses resulting from interdiction of property during any period of interdiction. If people must be permanently resettled because their property is condemned, then a further cost is added, based on personal income losses and moving costs for a transitional period.

Other offsite costs are associated with the disposal of contaminated farm products and restrictions on crop production from contaminated farmland. In areas where decontamination has to be carried out or the land has to be interdicted, milk is discarded for three months and other crops for one year. In other areas, dose criteria are used to determine whether milk or other food products should be discarded. Further, farmland which has been contaminated is interdicted and cannot be used for crop production until a protective action criterion based on projected doses from ingestion of crops grown on that farmland is met. The cost of this interdiction is the estimated annual value of farm production multiplied by the number of years that production is prohibited. If the interdiction period exceeds eight years, the cost is taken to be the total estimated value of the interdicted farmland.

While MACCS calculates the offsite health impacts of radiological exposures, i.e., the number of early and late fatalities and injuries, it does not compute any costs related to the occurrence of these health effects. These costs include, for example, medical treatment costs, and costs related to loss of human life (whether calculated based on "loss of income" approach or the "willingness to pay" approach) which have been analyzed in Chapter 3 .

\subsubsection{Offsite Consequences Estimated in the NUREG-1150 Studies}

We report below the offsite consequences including the health effects and offsite damage costs from the NUREG-1150 study of severe accident risks for five commercial nuclear power plants. NUREG-1150 is a comprehensive, integrated risk study which incorporates the most recent information and insights on accident progression, phenomenology, containment response and source terms to obtain quantitative estimates of the risk and its uncertainty for various consequence measures, such as early fatalities and latent cancers. The plants analyzed in NUREG1150 are : Unit 1 of the Grand Gulf station (a BWR-6 boiling water reactor, with a Mark-III containment), Unit 2 of the Peach Bottom plant (a BWR-4 boiling water reactor with a Mark-1 containment), Unit 1 of the Surry station (a threeloop pressurized water reactor, PWR, with a subatmospheric containment), Unit 1 of the Sequoyah plant (a four loop PWR with an ice condenser containment), and Unit 1 of the Zion plant (a four loop PWR with a large dry containment).

In the NUREG-1150 methodology, the accident sequences leading to core damage are binned into plant damage states which serve as the entry points to the accident progression event tree (APET). The outcomes of the APET are binned into the accident progression bins (APBs) whose characteristics are used to generate the source terms for each bin. By repeated sampling from the distributions which characterize the uncertainty in the key variables, many thousands of source terms are generated.

Each source term is characterized by a set of variables which includes: fractional releases from the core inventory of 9 radionuclide groups (noble gases, iodine, cesium, barium, strontium, ruthenium, 


\section{Offsite and Onsite Damage Costs}

cerium, and lanthanum), timing and duration of the release, and the release height and energy. Since it would be impractical to run the consequence code for all of the source terms they are partitioned into groups based on their health effect weights, i.e., their potential for causing early and latent fatalities. The source term parameters which mainly impact the health effect weights are the radionuclide release fractions and the timing of the release (the latter is especially important for the early fatalities category). Consequence calculations are then performed for the mean source term in each group. The distributions of the outputs of the consequence calculations, which sample the effects of the variability due to weather at each site, are then combined with the distributions resulting from the analyses of plant damage states and the accident progression bins to obtain the integrated risk of a particular consequence measure. Further details of the methodology used to obtain integrated risk in the NUREG-1150 study are contained in Reference [7].

In the NUREG-1150 study, the consequence analysis was carried out using Version 1.5.11 of the MACCS code. This version, it should be noted, was essentially based on the BEIR III risk coefficient rather than the higher BEIR V coefficient for predicting latent cancers from the population dose. In the consequence calculations reported below, we have used the latest version of MACCS, Version 1.5.11.1 [8], which explicitly incorporates the BEIR V risk coefficient for the latent cancer-dose relationship. In addition, the economic data used to calculate offsite damage costs have been updated to 1990 dollars and a few input errors in the NUREG1150 MACCS calculations have been corrected.

The consequence calculations reported for each of the NUREG-1150 plants are based on the mean source term groups (after partitioning) for accident sequences initiated by internal events, equipment failures and human errors, while the plant is at fullpower operation. For two sites in NUREG-1150, Surry and Peach Bottom, externally initiated events (seismic and fire) were also considered. Source terms due to external initiators have not been included in the consequence calculations reported below. The source term groups analyzed cover a wide range of accidents such as:

- small and large loss of coolant accidents (LOCAs),

- containment bypass releases (interfacing system LOCAs and steam generator tube ruptures), anticipated transients without scram (ATWS) events,

- loss of all ac power (station blackout) events.

These source terms cover a wide range of releases and consequences from small radionuclide releases with negligible or minor consequences (less than the population dose reported for the Three Mile Island accident, for example) to very large releases and consequences (approaching or surpassing the Chernobyl accident). Hence, these source terms are believed to be a reasonably representative sample of the range of releases and their frequencies which could arise from severe accidents at U.S. nuclear power plants. They are thus appropriate for use in a study devoted to examining the offsite damage costs of accidents at nuclear power plants.

The source terms analyzed in this study have been taken from the individual plant reports of NUREG1150. These reports are contained in the NUREG/CR-4551 series of reports and include Grand Gulf [9], Peach Bottom [10], Sequoyah [11], Surry [12] and Zion [13]. Tables 4-1 through 4-20 show the individual source terms (numbered according to the references above) and their consequences including early fatalities, population dose, latent fatalities, and offsite damage costs at the following distances from the reactor site: 10 miles, 50 miles, 100 miles and 1000 miles. To obtain a feel for what the mean source term groups represent reference may be made to the NUREG/CR-4551 series of reports referred to above. An example is provided for the Surry source terms here. Source term groups SUR-01, SUR-02, SUR-03, SUR-05, SUR-06 and SUR-10 in Table 4-4 
represent mainly Event $\mathrm{V}$, the interfacing system LOCAs. SUR-14 is composed largely of steam generator tube ruptures (SGTRs). The other source terms are composed of contributions from different types of accidents such as station blackout, ATWS, etc. The most likely source terms (i.e. the ones with the largest frequency), SUR-15 and SUR-16, do not lead to any early fatalities and arise from accidents which do not result in containment bypass or early containment failure.

In performing the consequence calculations reported in Tables 4-1 through 4-20, the emergency protective assumptions and the long-term protective assumptions were the same as those assumed in NUREG-1150 study. The emergency response assumed that $99.5 \%$ of the population in the low population zone within 10 miles of the plant evacuated after a (site-specific) delay following the issuance of a general warning by the plant to the local authorities at a speed specified in the licensee's emergency plan. The remaining $0.5 \%$ of the population in the LPZ were assumed to follow normal activity. The long term protective assumption used in NUREG-1150 were to interdict land which could give a projected dose to an individual via the groundshine and resuspension inhalation pathways of more than 4 rem in 5 years ( 2 rem in the first year and 0.5 rem per year for the next 4 years. Banning of contaminated food and interdiction of agricultural land for crop growing was based on FDA protective action guides for exposure from ingestion for the food groups and crops modeled in the MACCS code (representative of an average U.S. diet).

The early fatalities are defined as the total number of fatalities occurring within one year of the accident (due to early exposure to the plume), and the latent cancer fatalities are those arising from both early exposure (but which did not lead to death within one year) and late (chronic) exposure. The population dose is the effective dose equivalent for whole body exposure due to both early and chronic pathways. The offsite costs are the sum of the costs of emergency response actions and long-term protective actions. The MACCS code calculates distributions of these consequences based on Monte Carlo sampling from one year of site-specific hourly weather and wind direction data. Tables 4-1 through 4-20 display the mean values derived from the distributions for each of the consequences output by the code. In Tables 4-1 through 4-20, only source terms with mean frequencies above $10^{-8}$ per year or which contribute more than $1 \%$ of the total mean risk are displayed.

\subsubsection{Discussion of Results}

Tables 4-1 through 4-4 display the mean consequences at various distances from the Grand Gulf plant which is located in a very sparsely populated area. The mean value of early fatalities for all of the source terms is considerably less than one indicating the sparseness of the population in the vicinity of the plant. (The code calculates fractional values of mean early fatalities since this is an average over many weather trials). The population dose for some of the larger source terms (GG-11-1, for example, which is also a very energetic release), as a function of distance, varies from about $9 \mathrm{E}+4$ person-rem at 10 miles to about $5.7 \mathrm{E}+5$ person-rem at 50 miles, $1.6 \mathrm{E}+6$ person-rem at a 100 miles and $9.6 \mathrm{E}+6$ person-rem over the whole region (extending to 1000 miles as modeled in the NUREG-1150 study). For the source term with the highest frequency (GG-18-1), the population dose varies from about $7 \mathrm{E}+3$ person-rem at 10 miles to $7 \mathrm{E}+4$ at 50 miles and $3.5 \mathrm{E}+5$ person-rem at a 1000 miles, while the offsite costs vary from $\$ 5 E+6$ (10 miles) to $\$ 1 \mathrm{E}+7$ (50 miles) and $\$ 1.1 \mathrm{E}+7$ at a 1000 miles. For this source term, the consequence results clearly show that the increase in population dose by a factor of 5 in going from 50 miles to 1000 miles is due to a large number of people receiving very small doses, below the assumed long-term interdiction limit of $4 \mathrm{rem}$ in 5 years, since the offsite costs due to land condemnation, etc. remain essentially the same over this range of distances. 
Tables 4-5 to 4-8 show the mean consequences at the specified distances for the Peach Bottom Plant which is located in an area of population density close to the average for the continental U.S. The mean value of the early fatalities for all source terms is less than one due to the effectiveness of the assumed emergency evacuation (of the population in the vicinity of the plant) in relation to the timing of the releases. For the largest release (PB-16-1) the population dose varies from $1.1 \mathrm{E}+7$ person-rem at 50 miles to $2.2 \mathrm{E}+7$ person-rem at 100 miles and $4.4 \mathrm{E}+7$ person-rem at 1000 miles, that is a factor of 4 over the 50 to 1000 mile range while the offsite costs vary from $1.8 \mathrm{E}+10$ (50 miles) to $5.4 \mathrm{E}+10$ (1000 miles), that is a factor of 3 over the same range. For the source term with the highest frequency (PB-18-1) there are zero early fatalities; the population dose varies from $4.7 \mathrm{E}+3$ person-rem at 50 miles to $6.2 \mathrm{E}+3$ person-rem at 100 miles and $7.7 \mathrm{E}+3$ person-rem at 1000 miles, that is, by less than a factor of 2 over the 50 to 1000 mile range. The offsite costs stay essentially constant beyond 50 miles for this source term indicating that no additional land or property is interdicted or condemned beyond 50 miles.

The mean consequences at the Sequoyah plant are displayed in Tables 4-9 through 4-12. There are 8 source terms which have more than 1 mean early fatality. The largest source term (SEQ-14-3) results in 124 mean early fatalities; the population dose for this source term varies from $8.7 \mathrm{E}+6$ person-rem at 50 miles to $1.1 \mathrm{E}+7$ person-rem at 100 miles and $4.5 \mathrm{E}+7$ person-rem at 1000 miles, a factor of about 5 over the 50 to 1000 mile range, while the offsite costs over the same range also vary by a factor of 5 from $\$ 5.8 \mathrm{E}+9$ at 50 miles to $\$ 2.9 \mathrm{E}+10$ at 1000 miles. The source term with the highest mean frequency (SEQ-16-1) has zero early fatalities, a very small population dose (much less than TMI) and negligible offsite costs.

Tables 4-13 to 4-16 show the mean consequences at Surry. There are 5 source terms with more than 1 mean early fatality. The largest source term (SUR-
11-3) results in over 5 mean early fatalities, a population dose varying by a factor of 7 from $3 E+6$ person-rem at 50 miles to $2.1 \mathrm{E}+7$ person-rem at 1000 miles and offsite cost varying by a factor of 2 from $\$ 5.1 \mathrm{E}+9$ to $\$ 1.0 \mathrm{E}+10$ over the same range. The source term with the highest frequency (SUR16-1) has zero early fatalities, small population doses (less than $1 \mathrm{E}+3$ person-rem at 50 miles) and small offsite costs (less than $\$ 2 \mathrm{E}+4$ and all within 10 miles of the plant.)

The mean consequences for Zion are shown in Tables 4-17 to 4-20. There are 12 source terms at Zion with more than 1 early fatality. The largest source term (ZIO-178) leads to 355 mean early fatalities, a mean population dose ranging from $4.4 \mathrm{E}+7$ person-rem at 50 miles to $1.2 \mathrm{E}+8$ personrem at 1000 miles and a mean offsite cost ranging from $\$ 3.9 \mathrm{E}+10$ to $\$ 9.8 \mathrm{E}+10$ over the same distance. The source term with the largest frequency (ZIO301 ) has zero early fatalities, and negligible values of mean population dose (less than 200 person-rem out to 50 miles) and mean offsite costs.

\subsubsection{Frequency-Averaged Mean Consequences}

As shown in the above discussion and in the data presented in Tables 4-1 through 4-20 there is a very large variability in the mean consequences of the different source terms at each plant due to differences in the release parameters such as magnitude (that is, fractions of the core inventory released), timing and energy. To obtain a single value of mean consequences which is representative of all of the source terms presented in the above tables we have constructed frequency-averaged mean consequences at each of the specified distances for each of the NUREG- 1150 plants based on the information contained in Tables 4-1 through 420. For any consequence, $C_{i}(x)$, evaluated at a distance $\mathrm{x}$ from the plant the frequency-averaged value $\bar{C}(x)$ is

$$
\bar{C}(x)=\sum_{i=1}^{N} \lambda_{i} C_{i}(x) / \sum_{i=1}^{N} \lambda_{i}
$$


where $\lambda_{i}$ is the frequency (per year) of source term $i$ and $N$ is the total number of source term groups. $\bar{C}$ can be understood as a frequency-averaged conditional mean consequence value, that is the mean value of the consequence conditional on the occurrence of the accident and weighted by the frequency of the accident.

The frequency-averaged conditional mean consequences are shown in Tables 4-21 through 4-24 for the various plants at each of the specified distances. Comparison of these results at, say, 50 miles (Table 4-22) and 1000 miles (Table 4-24) shows that the frequency-averaged population dose increases by a factor ranging from about 3.5 (Zion) to about 11 (Grand Gulf) with the other plants lying in between. The offsite costs over the same range of distances increase by a smaller factor ranging from about 1.8 (Zion) to 3 (Grand Gulf) with the other plants in between. What this shows of course is that at large distances from the point of release most of the accumulated population dose is due to a large number of people accumulating small doses below the long-term interdiction criterion assumed in the calculation. Tables 4-21 through 4-24 are based on the long-term interdiction limit of 4 rem in 5 years assumed in the NUREG-1150 study. In the next section, we have recalculated the values of the mean consequences, population dose, latent cancers and offsite costs, at each of the NUREG-1150 plants assuming different values of the interdiction limit to evaluate the variation of these consequences with the interdiction limit. The calculations have been performed for all of the source terms shown in Tables 4-1 through 4-20 out to 50 miles and 1000 miles from the plant. The results are discussed in the next section.

As requested in the Statement of Work, Tables 4-25 through 4-29 show the plume centerline doses at specified distances for each of the source terms at each plant.

\subsubsection{Variation of Offsite Costs and Doses with the Long-Term Interdiction Limit}

It has been pointed out earlier that the calculation of consequences at any particular site is strongly affected by the assumption underlying the emergency response (evacuation, sheltering, etc.) and the longterm interdiction criteria. Different assumptions, for example, on the fraction of the close-in population which participates in the emergency evacuation will lead to different results for doses due to early exposure and the number of early fatalities/injuries. Similarly, varying the long-term dose interdiction criteria will affect the calculation of population doses, latent cancers and offsite costs as discussed earlier in Chapter 1. Thus, the estimation of population doses (person-rem), offsite costs (dollars), and an inferred costs/dose (dollars/personrem) ratio is, to some extent, arbitrary, depending on the protective action criteria assumed in the calculation.

To estimate the effect of varying long-term interdiction dose limits on offsite costs, latent fatalities, and population doses, we have recalculated the consequences at each of the NUREG-1150 plants for the following limits: $3.5 \mathrm{rem}$ in 5 years ( 0.7 rem or 700 millirem per year), 2.5 rem in 5 years (500 millirem per year) and 1.5 rem in 5 years (300 millirem per year). These calculations were performed for all of the source terms at each plant shown in Tables 4-1 through 4-20 out to distances of 50 miles and 1000 miles. The results are available on computer media.

From these results, frequency-averaged mean conditional consequences were constructed at each plant for each of the above interdiction limits in the same manner as described above in section 4.1.3. The results out to 50 miles are shown in Tables 4-30 through 4-34 for Grand Gulf, Peach Bottom, Sequoyah, Surry and Zion respectively. Tables 4-35 
4 Offsite and Onsite Damage Costs

through 4-39 display the corresponding results out to 1000 miles. ( To facilitate comparison, the last row in each of the above tables repeats the results at the interdiction limit of 4 rem in 5 years or 800 millirem per year which were earlier displayed in Tables 4-22 and 4-24).

The results are along the lines qualitatively discussed earlier in Chapter 1, section 1.4. They show that as the interdiction limit is reduced, that is, made more stringent, the offsite costs progressively increase while the population dose and latent cancers decrease. For example, in going from 700 millirem per year to 300 millirem per year at Grand Gulf the averaged offsite cost at 50 miles rises from $\$ 2.0 \mathrm{E}+8$ to about $\$ 3.0 \mathrm{E}+8$ while the averaged population dose decreases from $1.86 \mathrm{E}+5$ person-rem to $1.55 \mathrm{E}+5$ person-rem. At Peach Bottom, the corresponding increase in averaged offsite cost is from about $\$ 3.0 \mathrm{E}+8$ to $\$ 5.15 \mathrm{E}+8$ and the decrease in averaged dose from $1.89 \mathrm{E}+6$ person-rem to $1.41 \mathrm{E}+6$ person-rem. The trends at the other plants, Sequoyah, Surry, and Zion are broadly similar. Figures 4-1 through 4-5 show plots of these results to 50 miles (averaged offsite costs and population dose) as a function of the interdiction limit for each of the five plants. These plots show an interesting feature. As the interdiction limit is reduced, the offsite costs in general rise more sharply than the decrease in population dose. Ultimately, a law of diminishing returns should set in as the interdiction limit is reduced; the reduction in total dose should get smaller as progressively larger costs of condemning land and property are incurred.

This feature is illustrated in Figures 4-6 through 4-10 where the ratio of the change in offsite costs to the change in population dose (out to 50 miles), i.e., $\Delta$ (Offsite Costs) $/ \Delta$ (Person-rem), is plotted as a function of the change in interdiction limit for each of the plants. This quantity is a measure of the additional offsite cost incurred for each unit (personrem) of population dose averted as the interdiction limit gets smaller. At Grand Gulf this ratio varies from $\$ 1930$ /person-rem averted (in going from 800 $\mathrm{mrem} / \mathrm{yr}$ to $700 \mathrm{mrem} / \mathrm{yr}$ ) to $\$ 3620 /$ person-rem averted (500 mrem/yr to $300 \mathrm{mrem} / \mathrm{yr})$. The corresponding figures at Peach Bottom are from \$2410/person-rem averted to \$5480/person-rem averted, at Sequoyah from $\$ 1830$ /person-rem averted to $\$ 4450$ /person-rem averted, at Surry from $\$ 3420$ /person-rem averted to $\$ 5550 /$ person-rem averted, and at Zion from $\$ 1670$ /person-rem averted to $\$ 4710$ person-rem averted. These results show that over the range of interdiction limits usually considered for restricting long-term public exposure to accidental releases the ratio of the averaged offsite costs alone to the averaged population dose averted is between 2 and 5 times higher than the guideline of $\$ 1000$ per person-rem averted, which was earlier supposed to be a conservative envelope for all costs (health-related and property-related costs).

\subsubsection{Total Costs as a Function of Long-Term Interdiction Limit}

The total cost of an accidental release can be defined as the sum of the offsite damage costs, ODC, and the health-related costs, HRC. The offsite damage costs which are calculated by the consequence code have been discussed in detail above. The health-related costs can be expressed as:

$$
H R C=E F C+L F C
$$

where $\mathrm{EFC}=$ early fatality costs and $\mathrm{LFC}=$ latent fatality costs. The early fatality cost can be simply written as:

$$
E F C=S V O L * E F
$$

where EF is the number of early fatalities and SVOL (\$) is the selected statistical value of life. The latent fatality costs have to be discounted to present value due to the latency period between the time of exposure and the induction of the cancer. Table 2-1 in Chapter 2 displays the risks and latency periods for various types of cancer due to radiation exposure. We can then write the latent fatality costs 
as the product of SVOL and the number of latent cancers:

$$
L F C(r)=S V O L * \sum_{j=1}^{N} \frac{L F_{j}(r)}{(1+d)^{l_{j}}}
$$

where

$$
\begin{array}{ll}
L F_{j}(r)= & \text { number of latent fatalities due to cancer } \\
& \text { type } j \text { at an interdiction limit } r(\mathrm{mrem} / \mathrm{yr}), \\
l_{j} & =\text { latency period of the } j \text { th type of cancer, } \\
d & =\text { discount rate (\%/year), } \\
N & =\text { number of cancer types, and } \\
r & =\text { long-term interdiction limit (mrem/yr). }
\end{array}
$$

The total cost, $T C(r)$, of an accidental release can then be written as:

$$
T C(r)=O D C(r)+S V O L *\left\{E F+\sum_{j=1}^{N} \frac{L F_{j}(r)}{(1+d)^{l_{j}}}\right\}
$$

An approximation to the above expression for latent fatality costs is:

$$
L F C(r)=S V O L * \frac{L F(r)}{(1+d)^{\bar{l}}}
$$

where $\bar{l}$ is an approximate average latency period across all cancer types and $L F(r)=\sum_{N}^{j=1} L F_{j}(r)$ is the total number of latent cancers due to all cancer types for an interdiction limit of $\mathrm{r}$ (mrem/year). The total costs then simplify to:

$$
T C(r)=O D C(r)+S V O L *\left\{E F+\frac{L F(r)}{(1+d)^{\bar{l}}}\right\}
$$

We have used the above equation to obtain the variation in total costs out to 50 miles as a function of long-term interdiction level for each of the five plants. These calculations assumed: SVOL of $\$ 10$ million, a discount rate of $7 \%$, average latency period of 6.7 years and values of LF, number of latent fatalities, and ODC, offsite costs, taken from Tables 4-30 through 4-34. The values of EF, early fatalities, were taken from Table 4-22; early fatalities do not change with variation of the long-term interdiction limit.
The results are shown in Figures 4-11 through 4-15 for each of the five plants. These results display quantitatively the qualitative curve shown earlier in Figure 1-1. For most of the plants, the minimum of the total cost curve for the chosen SVOL lies at an interdiction limit $r$ in the range of 500 to $700 \mathrm{mrem}$ per year. For this particular SVOL, an interdiction limit of $500-700$ mrem per year thus represents an optimum from the cost standpoint with the offsite costs calculated by the MACCS code. A lower value of SVOL would generally lead to a higher value of the optimal interdiction limit.

For the purpose of estimating the offsite cost/person-rem averted ratio, we take the value at the $500-700$ mrem per year interdiction limit as shown in Figures 4-6 through 4-10 for each of the five plants respectively as this provides an optimum from the standpoint of minimum total cost. At this range of interdiction limits, the value of the offsite cost/person-rem averted ratio is: $\$ 2500$ /person-rem at Grand Gulf, \$3300/person-rem at Peach Bottom, $\$ 3000 /$ person-rem at Sequoyah, $\$ 3500$ /person-rem at Surry, and $\$ 3000 /$ person-rem at Zion. The mean of these values across the five plants is approximately $\$ 3000$ per person-rem averted.

\subsection{Onsite Damage Costs}

The primary goal of the NRC in the licensing and regulation of commercial nuclear power plants is the protection of the public health and safety. Onsite damages at nuclear power plants due to accidents, or purely economic losses caused by extended outages, have traditionally been viewed as being the responsibility of the operating license holder (i.e., the utility and its owners). However, due to the regulated and interlinked nature of the electric power industry, the onsite costs of accidents or outages also imply costs to society as a whole. For example, an accident or the mandated closure of a nuclear power plant could have other impacts besides the loss of benefits and possible cleanup costs to the operating utility. Decreased system 
reliability, increased customer rates, or increased generation of replacement power by fossil fuels with possible negative impact on the environment (and, ultimately, on public health) are possible outcomes. This implies that averted onsite damage has social benefits; whether they should be included in a backfit analysis is a policy matter, which is outside the purview of this study.

Onsite costs are discussed here for the purpose of identifying all possible economic consequences of reactor accidents. In past value-impact analyses, onsite costs have been treated by NRC as cost offsets to the cost of implementation of the proposed safety options.

The Office of General Counsel (OGC) to the NRC has stated that "under no defensible view of costbenefit analysis can the agency exclude outright any consideration of averted onsite costs. However, given the agency's mission to protect the health, safety, and property of the public, averted onsite costs should be considered in backfit analysis not as benefits but rather as reductions in the costs associated with the proposed backfits" [14]. This advice implies that averted onsite damage costs should be included explicitly in the economic analysis of backfits, but as a negative cost on the cost side of the benefit-cost relationship, rather than as a positive value on the benefit side as is done, for example, with averted offsite costs of accidents.

A review of the literature reveals that the major items of onsite costs can be subsumed under the following categories:

1. Replacement energy and capacity

2. Plant repair

3. Cleanup, including decontamination

4. Early decommissioning

5. Utility/nuclear industry impact

6. Employee health costs

The amount of the total costs and its distribution over each of the above categories is obviously a function of the severity of the accident and/or the duration of the outage.

\subsubsection{Definition of Accident Severity}

For purposes of analysis, accidental events can be divided into three categories of increasing severity, minor or small, medium and large. These are consistent with the categorization of Burke and Aldrich [6]:

1. Outages and Minor Accidents. These events generally have no health or significant safety impacts associated with their occurrence. The core is not damaged, and there is no release of radiation, outside regulatory limits, to the environment. The events may arise from component failures or operator errors. (Outages may also arise from regulatory actions.) The principal risk category in this type of event is economic risk due to the lost output from the capital asset as well as the costs of repairing or replacing damaged components, etc. Hence, in terms of the cost categories defined above, the applicable ones for these events are replacement power, plant repair, and potential employee health costs during the repair period. The magnitude of the cost incurred for these events is generally dominated by the costs of replacement power which is a function of the length of the outage, which may range from a few hours to more than a year.

2. Medium-Severity Accidents. These accidental events involve core damage, including fuel melting and relocation, but no breach of the reactor vessel, nor a gross failure of the containment and no significant release to the environment. (TMI is an example of this type of accident.) Public health risk from these events will be generally small. There could be some health risk to the workers during the progression of the accident sequence as well as 


\section{Offsite and Onsite Damage Costs}

in the cleanup and decontamination phase. The main risk, however, would be economic due to the long outage time, the possible total loss of the plant, the costs of cleanup and decontamination, and cost incurred due to early decontamination if plant repair is not a feasible option. The frequency of these events is the core damage frequency which generally lies in the range of $10^{-4}$ to $10^{-6}$ per reactor-year.

3. Large Accidents. These events involve severe core damage and a failure of containment with a large release to the environment. Public health consequences will be significant. As far as onsite damage costs are concerned, all the categories enumerated above, with the possible exception of plant repair if early decommissioning is elected, will be relevant. The severe accident analyses performed under NRC's NUREG-1150 program provide state-ofthe-art models and assessments regarding the likelihood and consequences of such accidents. The frequency of these events may be evaluated approximately as the conditional probability of containment failure given core damage multiplied by the frequency of core damage (i.e., in the range of $10^{-5}$ to $10^{-9}$ per reactor-year).

\subsubsection{Review of Onsite Damage Cost Estimates}

\subsubsection{Replacement Energy/Capacity}

When an operating nuclear power plant is forced to suspend production for any reason (e.g., an accident, an outage, or a regulatory action), the net cost of replacing this lost output for the duration of the outage is the replacement energy cost. In general, utilities have a number of options to choose from in trying to meet the shortfall created by the loss of a generating unit. The choice of option depends largely on the duration and timing of the outage and is a part of the utility's operating procedures. Replacement energy could include purchases from other utilities or increases in utility's own generation capacity by bringing other plants on stream, deferring planned retirements, accelerating new plant construction schedules, etc.

Detailed studies of the cost of replacement energy incurred due to short-term shutdowns (up to about one year) of nuclear power plants in the United States have been carried out by Argonne National Laboratory (ANL) for the NRC [15]. A detailed production cost model based on probabilistic simulations of load dispatch in 33 power pools located in the 9 regions of the North American Electric Reliability Council (NERC) was utilized by ANL to estimate the replacement energy costs arising from the short-term shutdown of a particular nuclear generating power plant.

The replacement energy costs in the ANL study were calculated in undiscounted 1985 dollars for each of the currently operating plants and for plants which were expected to be in service by the year 1991. The costs estimated cover the period 19871991. Table S.1 of NUREG/CR-4012, Vol. 2, provides the results of the ANL study for each plant in terms of average daily replacement energy cost, and Tables 5.4 through 5.119 show the results in mills $/ \mathrm{kWh}$ replaced $(10$ mills $=1 \mathrm{cent})$.

The total daily replacement energy cost varies considerably depending on unit size, plant location, and the season in which the outage occurs. The variability due to unit size is obvious; larger plants with greater outputs will have a larger total replacement cost. On a normalized basis, cents/kwh, the variability factor in replacement energy cost is about 4 and is primarily due to plant location (i.e., the region and the specific power pool in which the plant is situated). For example, in power pool 18 of the Southeastern Electric Reliability Council (SERC) region, the average replacement energy cost for a $1100 \mathrm{MW}$ plant is around $10 \mathrm{mills} / \mathrm{kWh}$; in power pool 27 of the Western Systems Coordinating Council (WSCC) region, this cost for the same plant size is over $42 \mathrm{mills} / \mathrm{kWh}$. The regional location has an important effect on replacement energy cost due to the fact that the mix of alternative generating 
units, the fuels used (and their costs), the availability of excess generation capacity, and the power transfer capability of the interconnected network, varies considerably between individual power pools and between regions. Seasonal variability in replacement energy cost is power pool and region specific. It depends on the shape of the annual load curve, the maintenance schedule for the base-load generating plants, and the availability of hydroelectric generation which is season dependent. For individual plants, seasonal variability in replacement energy cost ranges from negligible to a factor of about two.

Uncertainties in the future costs of replacement energy can be due to several factors: (1) changes in the prices of fuels, principally oil and gas, (2) effect of multiple plant shutdowns, (3) the role of system reliability, and (4) variations in hydroelectric generation. ANL carried out a sensitivity study of the effects on replacement energy cost due to a 50 percent change over a base case assumption of oil price (base case: $\$ 20$ /barrel, low case: $\$ 10$ /barrel, high case: $\$ 30 /$ barrel). The results are power pool specific; in those locations where oil/gas are the major replacement energy sources, the effect on replacement energy costs is almost equal to the change in the oil price. In other areas, where adequate coal-fired capacity is available, the impact of oil price variations is negligible. The effect of multiple shutdowns on replacement energy costs is also power pool specific and depends on the system reserve margins and the mix of fuels available for replacement generation. A system with a low reserve margin could experience reliability problems and possible additional costs of unserved energy. Generally, in systems with adequate reserves, the costs of replacement energy in the event of multiple shutdowns is close to the summed cost of individual unit shutdown. In systems without sufficient reserves, the total costs of multiple shutdowns are significantly higher than the single unit summed costs.
The ANL study generally provides the most detailed data base available for calculating replacement energy costs for outages of short-term duration. A single "generic" value of replacement energy cost for such outages is difficult to pinpoint due to the variations discussed above; however, for a "typical" $1100 \mathrm{MW}$ plant, a figure of $\$ 500,000$ per day would be close to an average. The uncertainty in this value would be in the range of 50 percent due to the factors discussed above.

For longer-term shutdowns lasting for several years, applying the above results would not be appropriate since utilities would try to adopt more optimum solutions when faced with an extended loss of a nuclear power plant. This implies that for a multiyear outage, the increase in production cost calculated on the basis of the short-term replacement power cost would be higher than what would actually occur in practice, since utilities would adopt more cost-effective strategies in the long term. These considerations apply particularly to mediumscale or severe accidents where the damage to the plant is such that abandonment is the only possible outcome. In these cases, replacement power would have to be planned for an extended period; the remainder of the abandoned plant's useful life, or until a new plant of equivalent capacity could be constructed and brought on line.

An alternative, approximate methodology was proposed by ANL in an earlier study [16] to allow for a quick, first-cut calculation of a range of replacement energy costs for extended nuclear power plant outages. This methodology was based on the recognition that the fraction of replacement energy, in each NERC region, derived from oil-fired sources and other noneconomy purchases (e.g., high marginal cost gas turbines) was an important variable in explaining the range of replacement power costs. ANL established an approximate correlation between a first-year production cost increase (calculated in units of $\$ 10^{6}$ per Mw-year) 
and the percentage of replacement energy, in each region, derived from oil-fired plants and other noneconomy sources. This correlation was utilized in studies by Strip [17], Burke and Aldrich [6], and Heaberlin, et al. [18], in calculating the replacement power component of the onsite damage costs in the event of extended outage or plant abandonment.

In the event of extended outages, the validity of the correlation derived in [16] is doubtful and an alternative approach is needed. A preliminary attempt at calculating replacement power costs for a long-term outage is based on the assumption that for a certain period, say 3 to 5 years, the costs estimated in the ANL short-term calculations [16] will continue to remain valid. Beyond this period, it is assumed that the affected utility will be able to reduce the replacement power costs to around half of their short-term value. While this assumption is arbitrary, the reduction factor can be treated as a sensitivity parameter and its impact on the discounted present value of replacement power cost can be calculated. The results are summarized in Section 4.2.2.5 below where the total onsite damage costs are estimated.

Over the longer term, there could be a need for new capacity to replace the original capacity lost due to the accident arising from considerations of system reliability and economics. A part of the capital costs associated with the replacement capacity could then be a relevant incremental cost of the accident.

Burke and Aldrich [6] suggested a methodology to calculate the cost of replacement capacity, based on the societal costs of providing the same future benefits which would have been provided by the original plant had the abandonment not occurred. This method of accounting assumes that a new power plant of the same aggregate capacity would be constructed to replace the abandoned plant and that the new plant would take at least 10 years to construct before entering commercial service. The cost of replacing the original capacity is then calculated as the sum of replacement energy costs integrated over 10 years and the amortized value of the capital cost of the new power plant over the number of years the original plant still had left in service had the accident not occurred.

It should be noted that this category of onsite damage costs applies only to medium-scale and large accidents which could damage a reactor sufficiently to cause its abandonment.

\subsubsection{Cleanup and Decontamination Costs}

A medium-scale or severe accident can cause contamination of the various compartments of the nuclear power plant by radioactive materials released from the reactor coolant or the core of the reactor. The cleanup and decontamination of the plant to bring the site premises back to a safe condition can involve significant costs, as the experience with TMI has demonstrated. This section reviews (1) the costs associated with the cleanup at TMI, (2) studies performed by Pacific Northwest Laboratories (PNL) [19] on the cleanup and decommissioning costs, and (3) estimated made by Burke and Aldrich [6].

The PNL study divides the time phases of the cleanup program into two components: the preparation period and the duration of the cleanup itself. In each phase, a number of applicable cost categories are defined; labor (including operations, staff support, and cleanup labor), energy, specialty equipment and facilities, supplies, specialty contractors, waste management and insurance and license fees. In the cleanup period, a separate cost category is defined for disposal of the damaged fuel from the reactor core.

Three accident scenarios are defined in the PNL study. Scenario 1 results in 10 percent fuel cladding failure, no fuel melting, a moderate contamination of the containment building, and no significant damage to the plant buildings and equipment. 
Scenario 2 results in 50 percent cladding failure, some fuel melting, extensive contamination of the containment, moderate contamination of the auxiliary and fuel buildings, and minor damage to plant and equipment. Scenario 3 involved 100 percent cladding failure, significant melting of fuel and severe core damage, severe contamination of the containment, moderate contamination of the auxiliary and fuel buildings, and major damage to plant and equipment. The PNL study does not allow for failure of the pressure vessel boundary or catastrophic failure of the containment. Comparison of these scenarios with the accident categories adopted above shows that the severe accident category is not covered by the PNL study. For each of the accident scenarios, PNL assigned a specific duration for the two phases of the cleanup effort and then estimated the physical quantities (e.g., man-years of labor of different types, energy consumed, etc.) expended over this period. Multiplication of the physical quantities by their unit values, estimated in constant 1981 dollars, then resulted in total cleanup costs.

For a reference BWR and a reference PWR, the cleanup costs (in millions of constant 1981 dollars) estimated by PNL, broken down by accident scenario were as follows:

\begin{tabular}{ccc} 
Scenario & BWR & PWR \\
\hline 1 & 128 & 105 \\
2 & 228 & 224 \\
3 & 421 & 404
\end{tabular}

The TMI accident lay somewhere between Scenarios 2 and 3 of PNL, although closer to Scenario 3 in terms of the contamination and damage to the core. Comparison with the actual expenses incurred for cleanup at TMI provides a check on the estimates made by PNL and also gives a good reference point for the cleanup costs of a medium-scale accident.

The total cleanup and decontamination costs for TMI were estimated in 1981 at a little over one billion dollars ( $\$ 1.035$ billion) in undiscounted current year dollars over an eight year cleanup effort [20]. In minor revisions subsequently, a figure of $\$ 965$ million has been quoted. This figure of total costs, spread over eight years, included an allowance of $\$ 209$ million for cost escalation due to inflation. If this is subtracted out, the cleanup cost for TMI, in constant 1981 dollars, can be estimated to be about $\$ 750$ million. The main reasons for the differences between the PNL estimates and the actual costs for TMI were attributed by PNL to three factors: (1) Costs imposed by regulatory and financial requirements which delayed the start of cleanup at TMI by approximately 2.5 years, in which about $\$ 226$ million was incurred for stabilization of the plant, maintenance in a safe shutdown condition, and preparations for accident cleanup. The PNL study assumed no additional regulatory or financial delays between the occurrence of the accident and the start of the cleanup. In the conditions likely to prevail after an accident, this assumption is somewhat unrealistic. (2) Differences in the facilities required to complete the decontamination. TMI costs included a hot chemistry laboratory, a containment recovery service building, and a comment center/temporary personnel access facility which together amounted to $\$ 84$ million. Based on the design and layout of the "reference" PWR, PNL assumed that such facilities were not required. (3) Differences in the scope of the accident cleanup activities--mainly, the additional decontamination of the containment building after defueling of the reactor. This activity, estimated in the TMI cleanup at $\$ 100$ million, was excluded from the scope of the PNL work.

The cleanup and decontamination costs of a severe, large-scale accident involving vessel breach and containment failure are expected to be significantly higher. The gross contamination of the building surfaces and the associated radiation fields within the plant would be expected to be much higher than those observed at TMI. This would imply that the turnover of cleanup personnel and the total manhours expended in the cleanup would be much 
larger leading to significantly greater labor costs, which themselves amount to about 50 percent of total accident cleanup costs.

Burke and Aldrich [6] have made a very rough estimate of the cleanup and decontamination costs following a severe accident. Their "best estimate" is twice the TMI costs or about $\$ 1700$ million (in constant 1982 dollars), with an "upper bound" of three times the TMI cost or about $\$ 2500$ million. The lower bound is the same as TMI. Hence, for severe accidents, these estimates introduce an uncertainty factor of about three. In reality, the uncertainty could be somewhat larger, caused by the actual mechanism of containment failure. For example, basemat meltthrough, which would have smaller airborne releases (in comparison with other categories of containment failure) could considerably raise the costs of onsite cleanup, especially if underground aquifers were threatened. More detailed modeling of severe accident physical processes could help to elucidate the onsite cleanup and decontamination costs.

Early decommissioning costs were examined in the PNL study for various decommissioning options, such as dismantlement, safe storage, and entombment after cleanup and decontamination were completed. A range of costs from $\$ 49$ million to $\$ 106$ million (1981 dollars) were estimated based on the option selected. Burke and Aldrich have reviewed various other studies and estimated a $\$ 100$ million post-accident decommissioning cost (1982 dollars).

\subsubsection{Plant Repair}

Most accidents and outages at nuclear power plants are likely to result in costs being incurred for repairing damaged components before the plant is placed back in operation. Such costs, however, would not be incurred for severe and even some moderate-scale accidents if a decision in factor of early decommissioning was made.
Based on data obtained for outages of various duration, Burke and Aldrich have estimated typical plant repair costs as being in the range of $\$ 1000$ per hour of outage duration, with an upper bound of around 20 percent of replacement power costs. The $\$ 1000 /$ hour of outage figure corresponds quite closely to the repair costs incurred in such accidents as the Browns Ferry fire and the TMI-1 steam generator retubing outage.

\subsubsection{Worker Health Costs}

The only significant health costs likely to be incurred in this category are for severe accident which causes injury or fatalities to plant personnel. Strip [17] estimated that an upper bound on injuries and fatalities to plant workers following a severe coremelt accident would be 10 early fatalities and 30 early injuries, based on a shift of 40 workers for a single plant. The financial consequences of this were estimated on the basis of $\$ 1$ million per fatality and $\$ 100,000$ per injury, to arrive at an upper bound for worker health costs of $\$ 13$ million per severe accident. This amount is small compared with the costs of other categories. Occupational health costs will also be incurred for small and medium-scale accidents were workers may have to decontaminate or repair the plant under high radiation conditions. If the annual occupational dose limits are observed, this will generally lead to a high turnover in the work force. This category of costs is subsumed under the labor costs of plant decontamination and repair.

\subsubsection{Total Onsite Costs of Severe Accidents}

The total onsite costs of a severe, category III accident have been estimated for (1) the Zion 2 power plant and (2) a "generic" $1100 \mathrm{Mw}$ plant assumed to have a remaining life (i.e., the number of years the plant is at risk) of 30 years. Two types of onsite costs have been considered. The first is an annual risk-based cost, the discounted net present 
4 Offsite and Onsite Damage Costs

value of the risk over the remaining life of the plant, which is proportional to the accident frequency, $\lambda$ per year. The second is a conditional cost, the discounted present value of the cost predicated on accident occurrence in the initial year of the period for which the reactor is at risk (i.e., the current year for an operating plant).

These costs, in 1990 dollars, estimated with a discount rate of 7 percent (as per NRC regulatory analysis guidelines [21]) are shown below:

\begin{tabular}{lcc} 
& Zion 2 & Generic Plant \\
\hline $\begin{array}{l}\text { Risk-based cost } \\
\text { (per year) }\end{array}$ & $3.4 \mathrm{E} 10 \times \lambda$ & $4.2 \mathrm{E} 10 \times \lambda$ \\
Conditional cost & $4.2 \mathrm{E} 9$ & $4.7 \mathrm{E} 9$
\end{tabular}

\subsection{References}

1. U. S. Nuclear Regulatory Commission, "Reactor SafetyStudy,"WASH-1400, NUREG075/14, October 1975.

2. L. Ritchie, et al., "Calculations of Reactor Accident Consequences, Version 2: Users Guide," NUREG/CR-2326, 1982.

3. H. N. Jow, et al., "MELCOR Accident Consequence Code System (MACCS): Model Description," NUREG/CR-4691, SAND861562, Sandia National Laboratories, February 1990.

4. U. S. Nuclear Regulatory Commission, "Severe Accident Risks: An Assessment for Five U.S. Nuclear Power Plants," NUREG-1150, Vol. 1, June 1989.

5. J. S. Evans, et al., "Health Effects Model for Nuclear Power Plant Accident Consequence Analysis," NUREG/CR-4214, Sandia National Laboratories, July 1985. Revised and Updated by $S$. Abrahamson, et al., "Health Effects Model for Nuclear Power Plant Accident
Consequence Analysis," NUREG/CR-4214, Rev. 1, Part II, May 1989.

6. R. P. Burke and D. C. Aldrich, "Economic Risks of Nuclear Power Plant Accidents," Sandia National Laboratories, NUREG/CR3673, April 1984.

7. E. D. Gorham, et al., "Evaluation of Severe Accident Risks: Methodology for the Containment, Source Term, Consequence, and Risk Integration Analyses," Sandia National Laboratories, NUREG/CR-4551, SAND86-1309, Vol. 1, Rev. 1, December 1993.

8. D. Chanin, et al., "MACCS Version 1.5.11.1: A Maintenance Release of the Code," Sandia National Laboratories, NUREG/CR-6059, SAND92-2146, October 1993.

9. T. D. Brown, et al., "Evaluation of Severe Accident Risks: Grand Gulf, Unit 1," Sandia National Laboratories, NUREG/CR-4551, SAND86-1309, Vol. 6, Rev. 1, Part 1, December 1990 .

10. A. C. Payne, et al., "Evaluation of Severe Accident Risks: Peach Bottom, Unit 2," Sandia National Laboratories, NUREG/CR4551, SAND86-1309, Vol. 4, Rev. 1, Part 1, December 1990.

11. J. J. Gregory, et al., "Evaluation of Severe Accident Risks: Sequoyah, Unit 1," NUREG/ CR-4551, SAND86-1309, Vol. 5, Rev. 1, Part 1, Sandia National Laboratories, December 1990.

12. R. J. Breeding, et al., "Evaluation of Severe Accident Risks: Surry, Unit 1," NUREG/CR4551, SAND86-1309, Vol. 3, Rev. 1, Part 1, Sandia National Laboratories, October 1990. 
4 Offsite and Onsite Damage Costs

13. C. K. Park, et al., "Evaluation of Severe Accident Risks: Zion, Unit 1," NUREG/CR4551, SAND86-1309, Vol. 7, Rev. 1, Part 1, Brookhaven National Laboratory, March 1993.

14. Memorandum, W. C. Parker to Commissioner Bernthal, "Consideration of Averted Onsite Costs in Backfit Analyses," June 4, 1987.

15. J. C. Van Kuiken, et al., "Replacement Energy Costs for Nuclear Electricity Generation Units in the U.S.: 1987-1991," NUREG/CR-4012, Vol. 2, Argonne National Laboratory, January 1987.

16. W. A. Buehring and J. P. Peerenboom, "Loss of Benefits Resulting from Nuclear Power Plant Outages," NUREG/CR-3045, Argonne National Laboratory, March 1982.

17. D. R. Strip, "Estimates of the Financial Consequences of Nuclear Power Reactor Accidents," Sandia National Laboratories, NUREG/CR-2723, September 1982.
18. S. W. Heaberlin, et al., "Handbook for ValueImpact Assessment," NUREG/CR-3568, Pacific Northwest Laboratories, December 1983.

19. E. S. Murphy and G. M. Holter, "Technology, Safety, and Costs of Decommissioning Reference LWRs Following Postulated Accidents," Pacific Northwest Laboratories, NUREG/CR2601, November 1982.

20. General Public Utilities Corp., "TMI-2 Recovery Program Estimate," Revision 1, July 1981.

21. U. S. Nuclear Regulatory Commission, "Regulatory Analysis Guidelines of the U. S. NRC," Draft Report for Comment, NUREG/ BR-0058, Rev. 2, August 1993. 
4 Offsite and Onsite Damage Costs

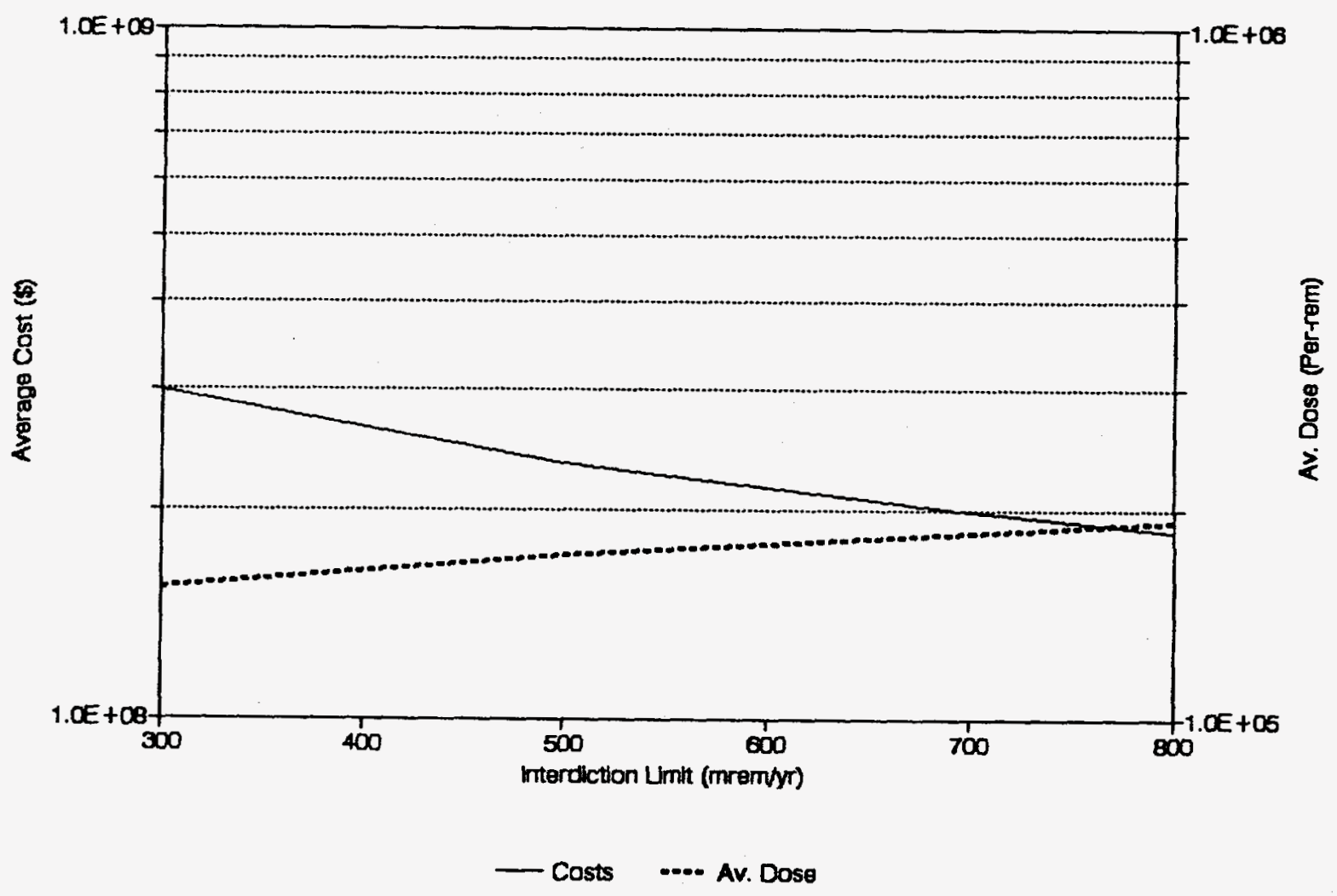

Figure 4-1 Frequency-Averaged Conditional Consequences at 50 Miles as a Function of Interdiction Limit, Grand Gulf 


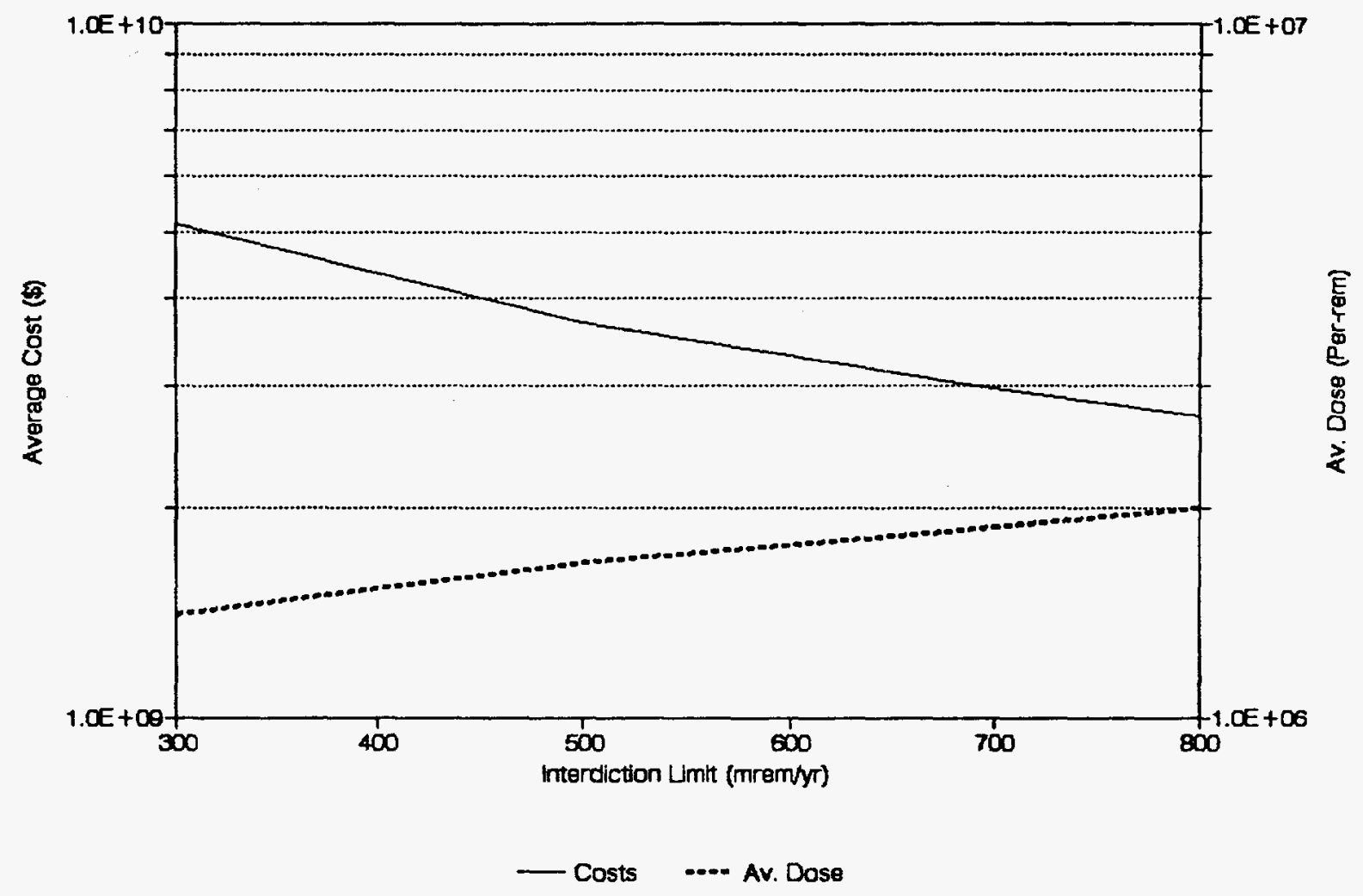

Figure 4-2 Frequency-Averaged Conditional Consequences at 50 Miles as a Function of Interdiction Limit, Peach Bottom 
4 Offsite and Onsite Damage Costs

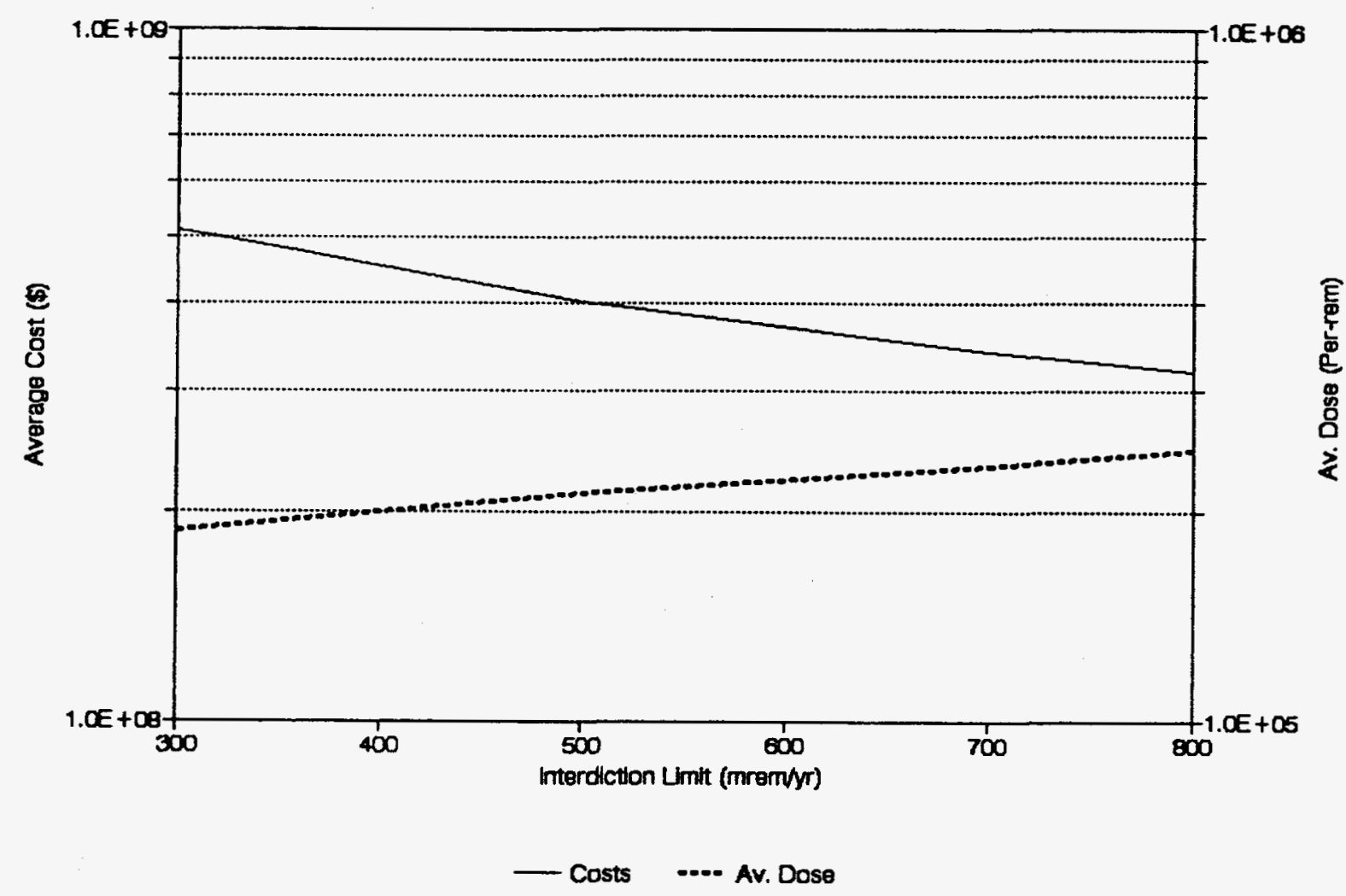

Figure 4-3 Frequency-Averaged Conditional Consequences at 50 Miles as a Function of Interdiction Limit, Sequoyah 


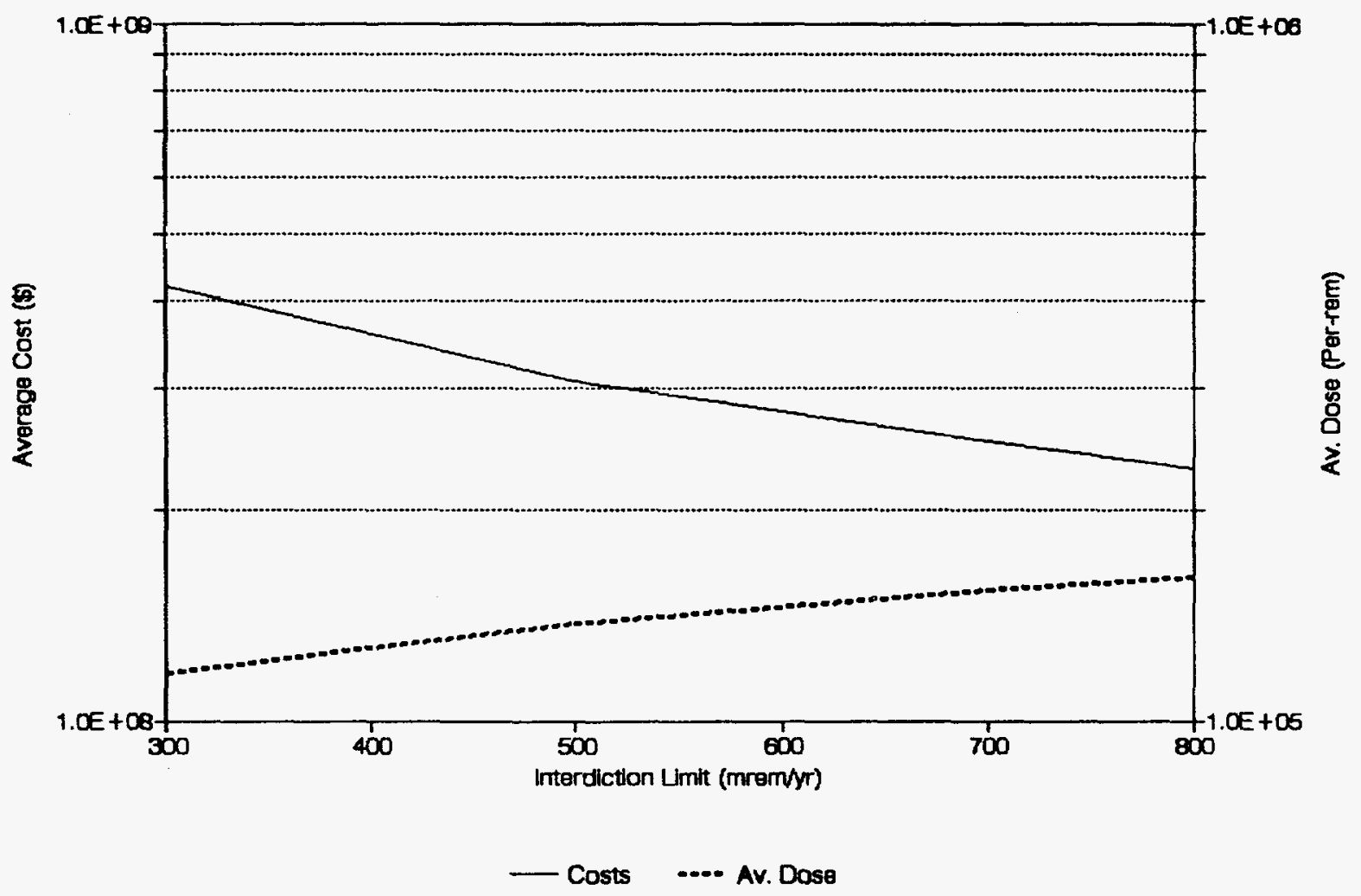

Figure 4-4 Frequency-Averaged Conditional Consequences at 50 Miles as a Function of Interdiction Limit, Surry 
4 Offsite and Onsite Damage Costs

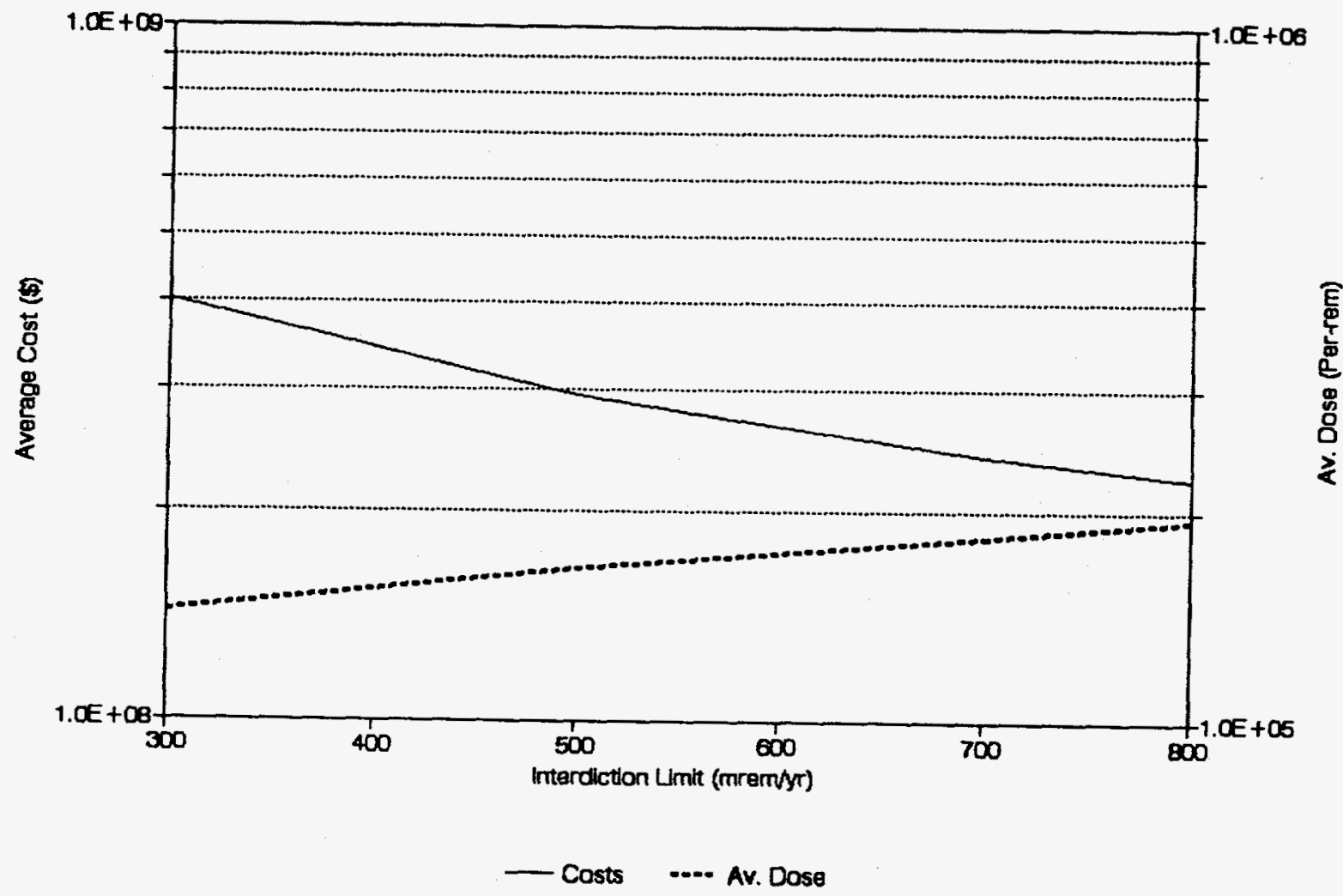

Figure 4-5 Frequency-Averaged Conditional Consequences at 50 Miles as a Function of Interdiction Limit, Zion 
4 Offsite and Onsite Damage Costs

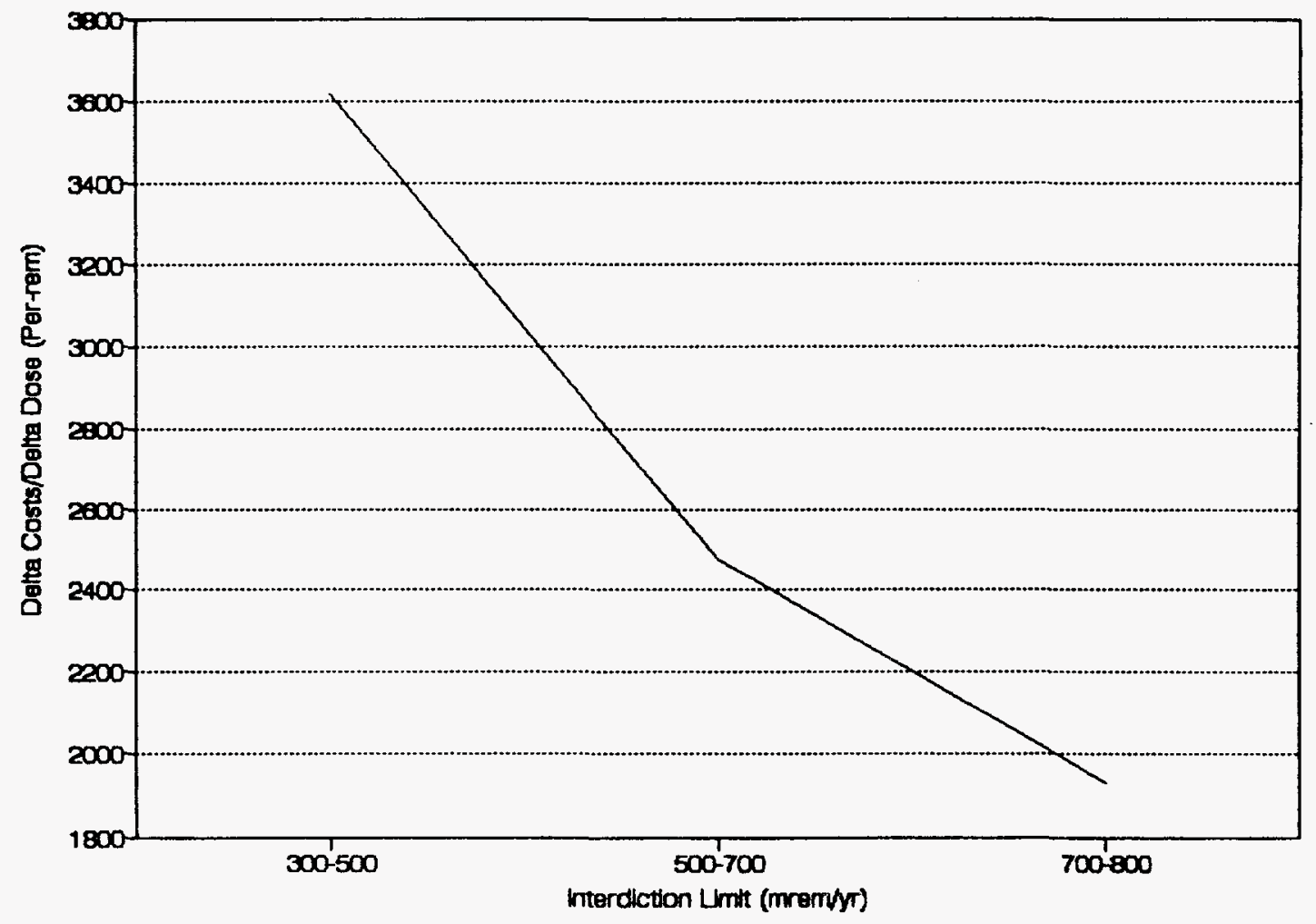

Figure 4-6 Ratio of Averted Offsite Costs to Averted Dose (Person-Rem) as a Function of Interdiction Limit to $\mathbf{5 0}$ Miles, Grand Gulf 
4 Offsite and Onsite Damage Costs

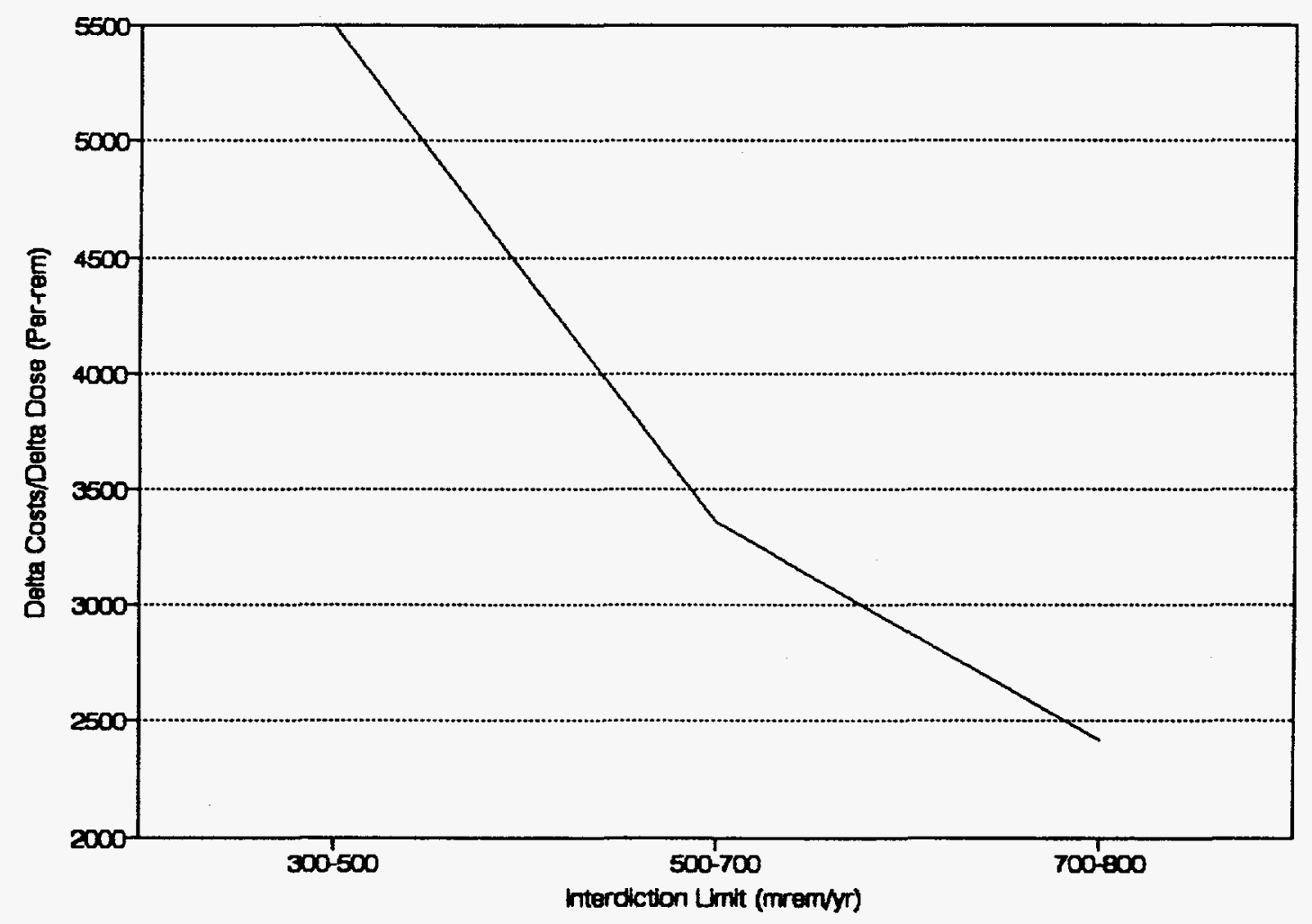

Figure 4-7 Ratio of Averted Offsite Costs to Averted Dose (Person-Rem) as a Function of Interdiction Limit to $\mathbf{5 0}$ Miles, Peach Bottom 


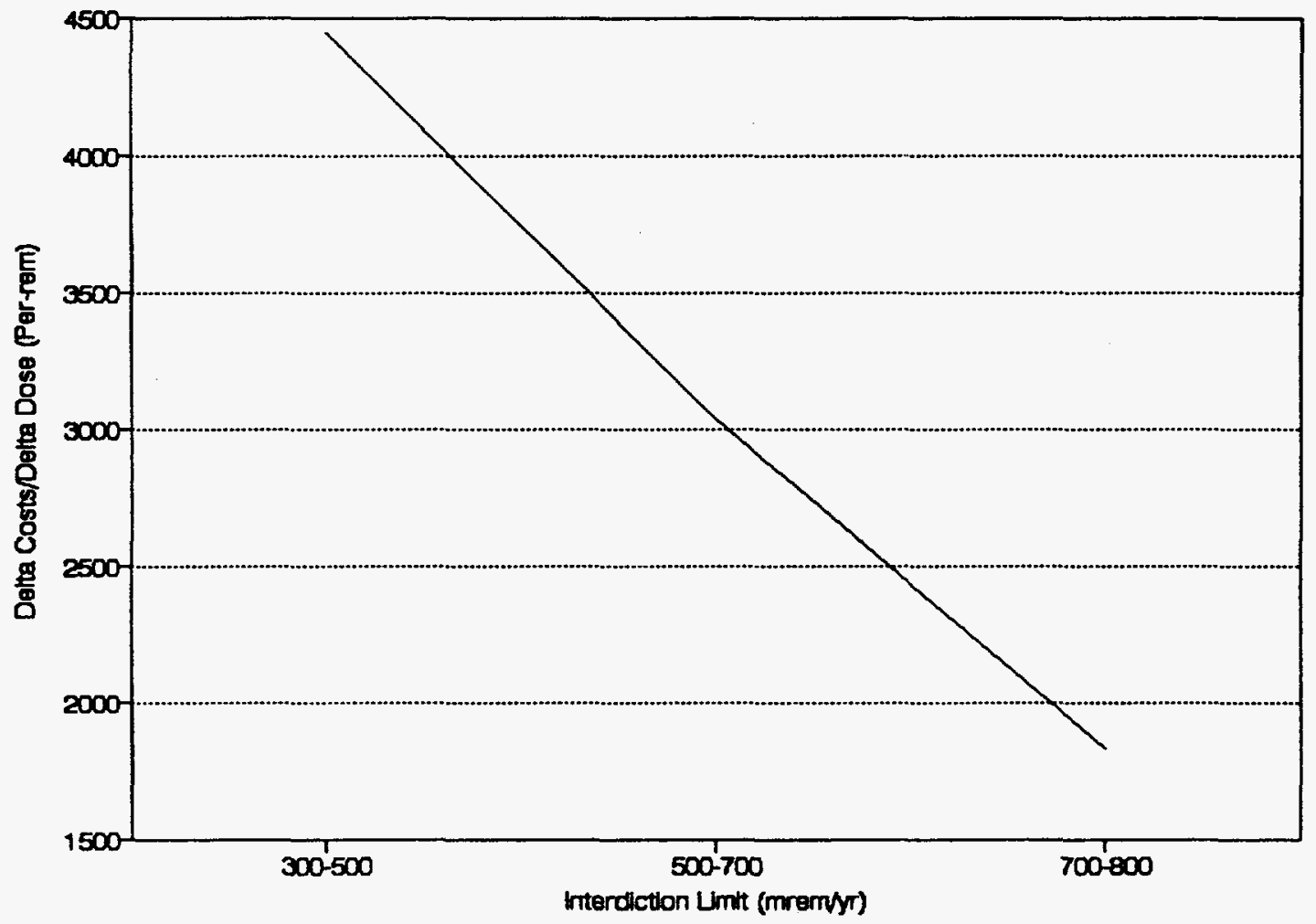

Figure 4-8 Ratio of Averted Offsite Costs to Averted Dose (Person-Rem) as a Function of Interdiction Limit to $\mathbf{5 0}$ Miles, Sequoyah 
4 Offsite and Onsite Damage Costs

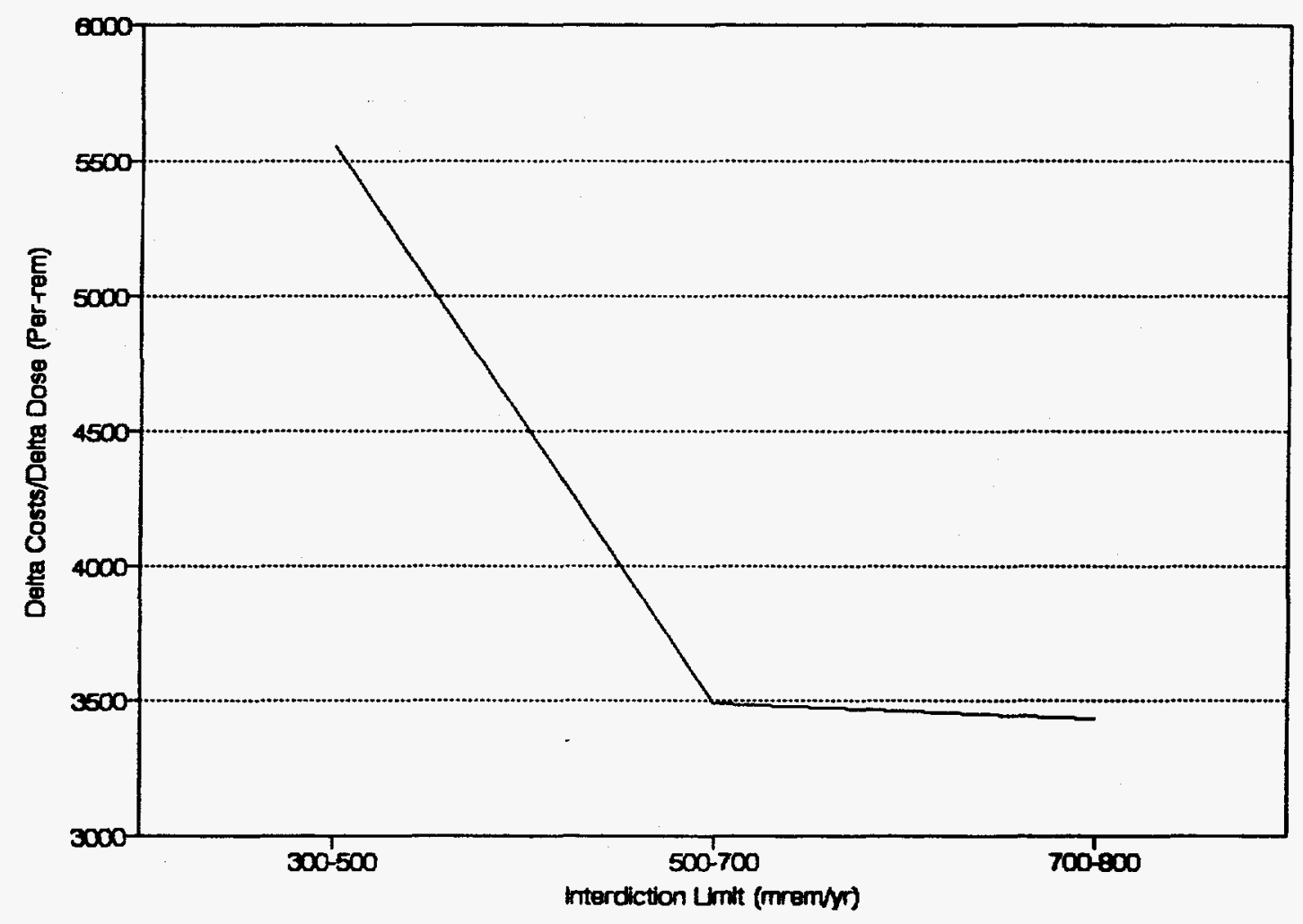

Figure 4-9 Ratio of Averted Offsite Costs to Averted Dose (Person-Rem) as a Function of Interdiction Limit to $\mathbf{5 0}$ Miles, Surry 


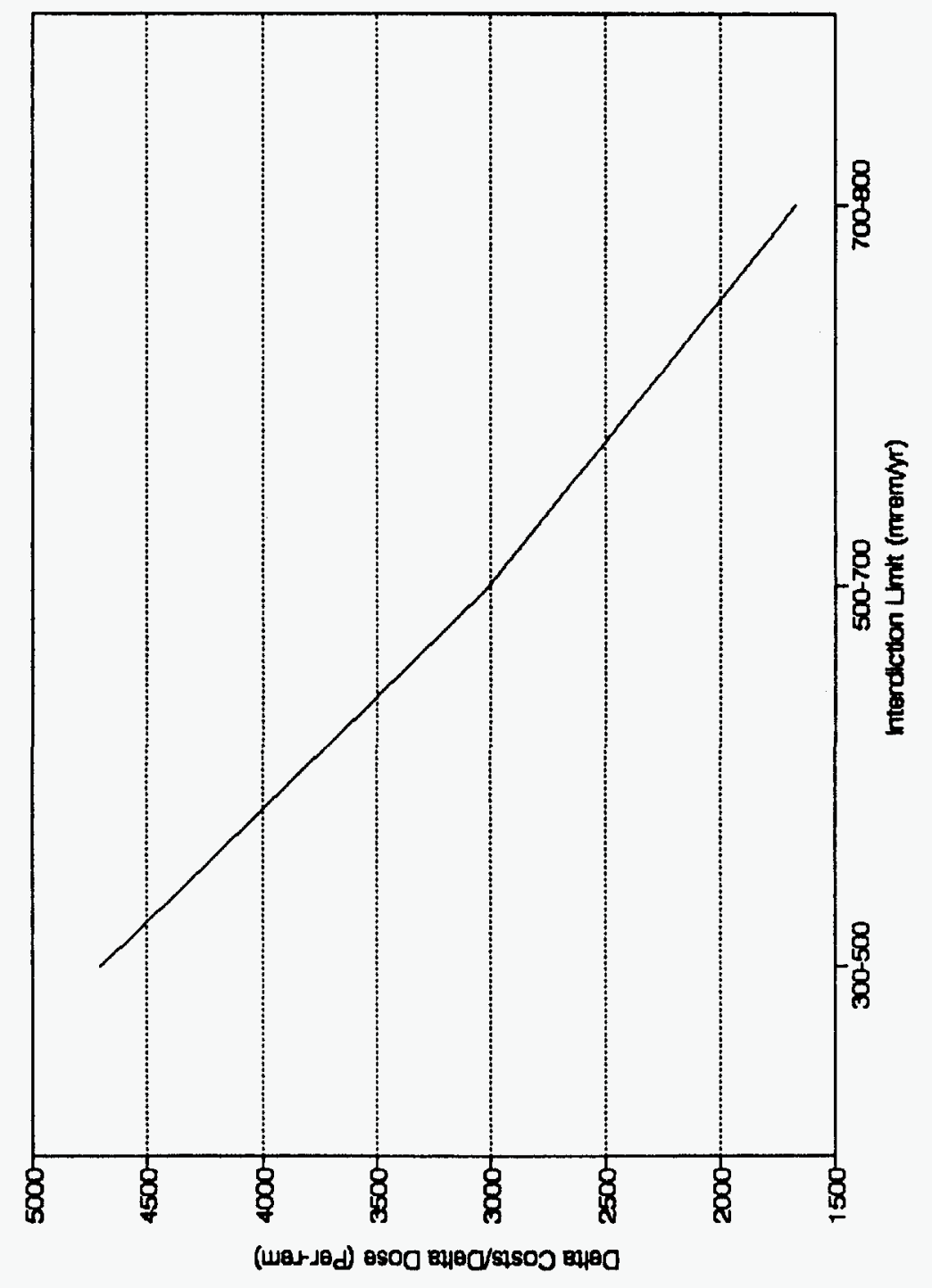

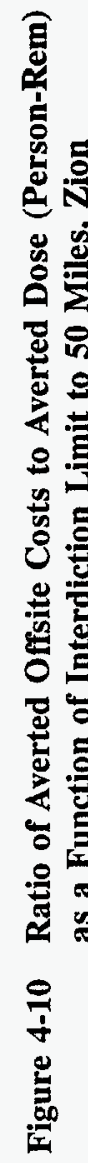


4 Offsite and Onsite Damage Costs

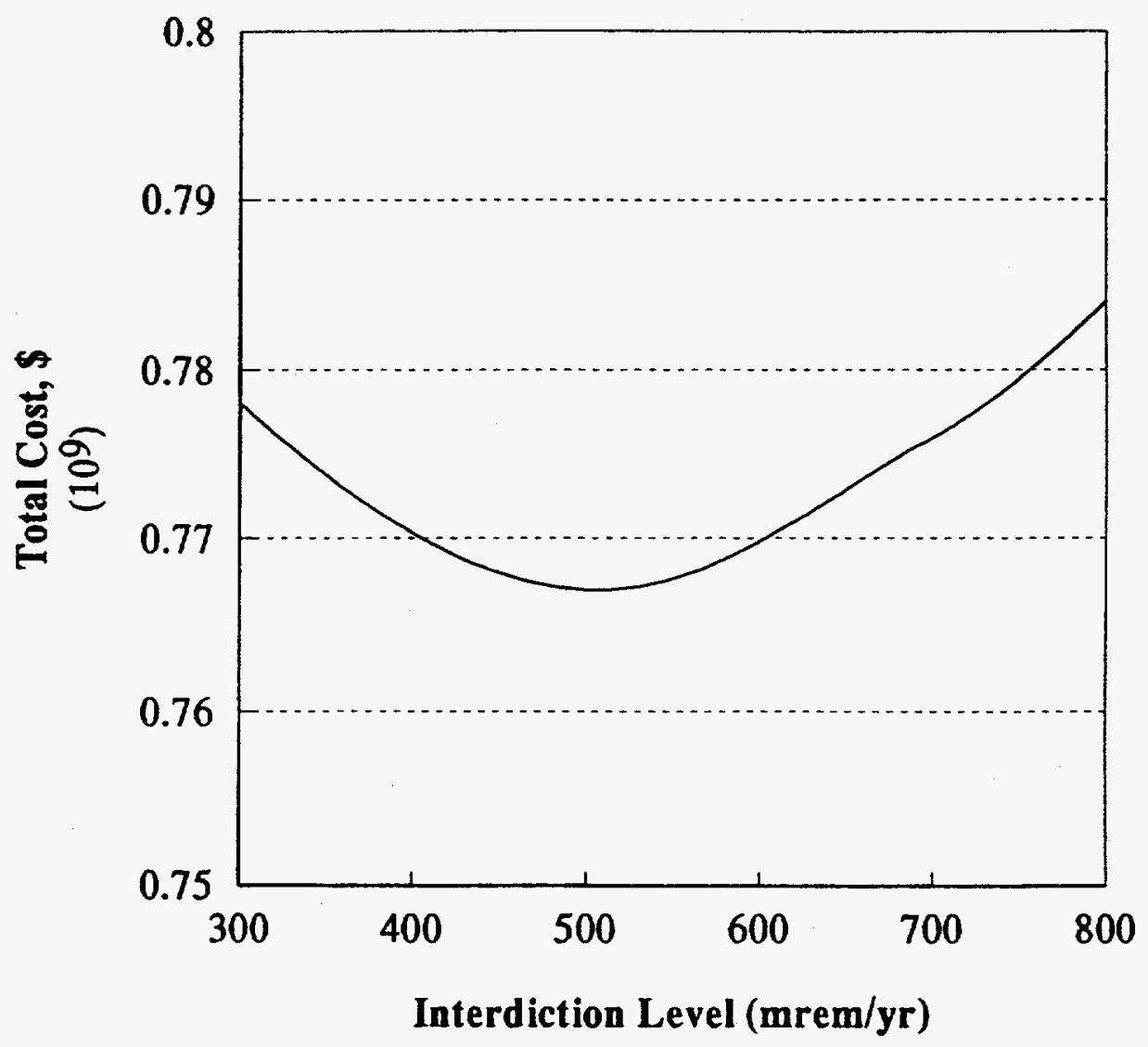

Figure 4-11 Total Cost at 50 Miles vs. Interdiction Level, Grand Gulf 
Offsite and Onsite Damage Costs

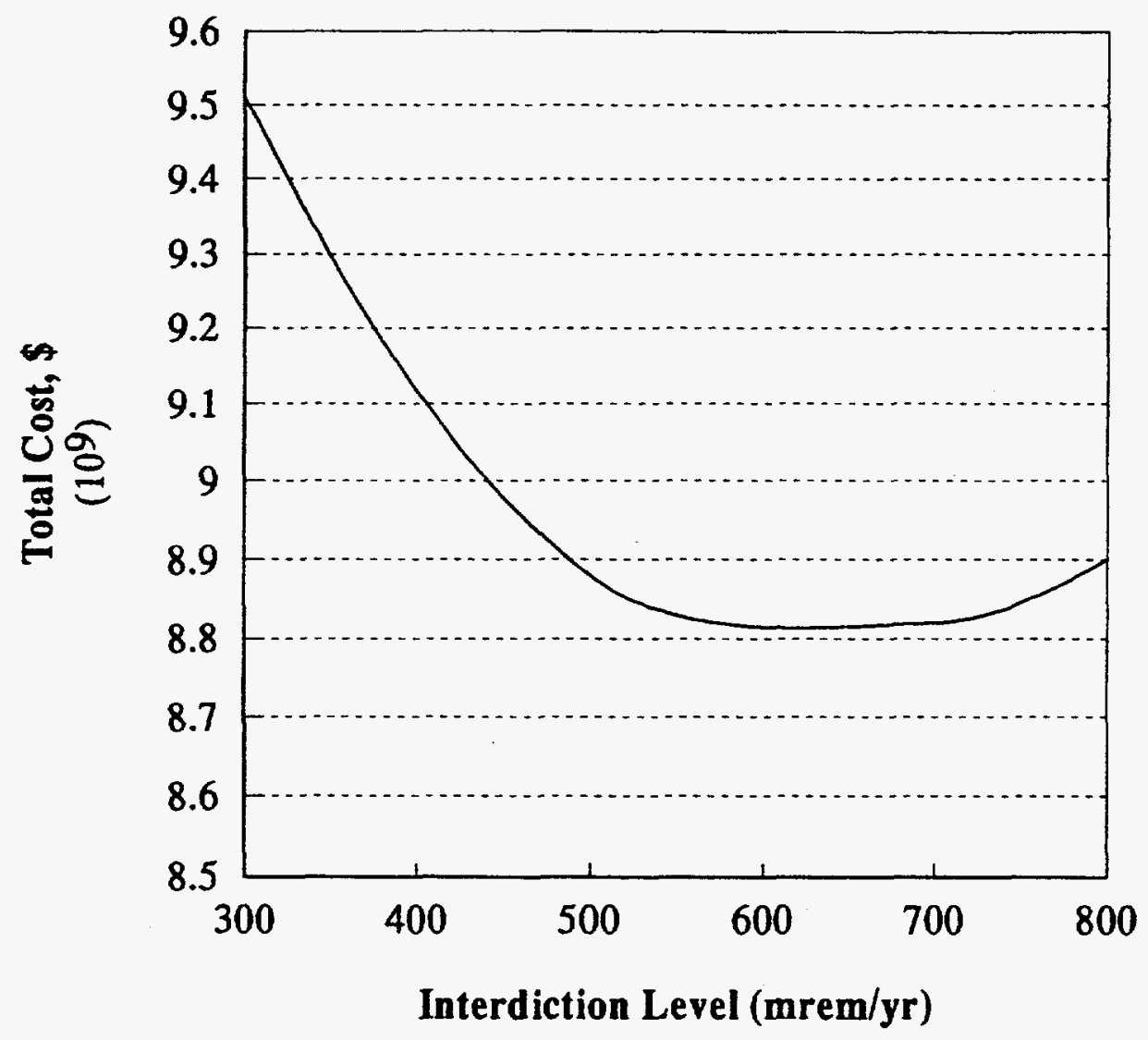

Figure 4-12 Total Cost at 50 Miles vs. Interdiction Level, Peach Bottom 
4 Offsite and Onsite Damage Costs

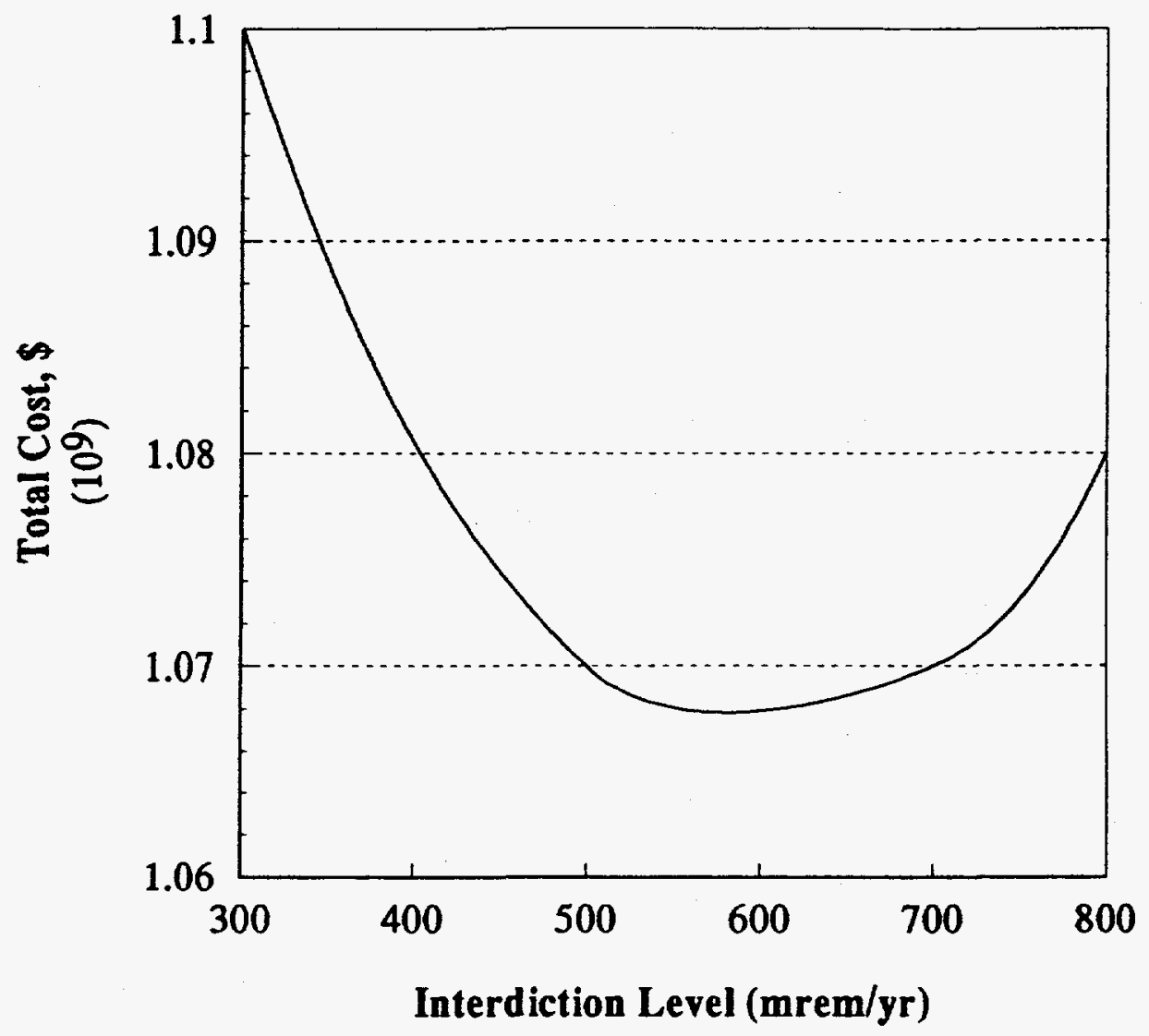

Figure 4-13 Total Cost at 50 Miles vs. Interdiction Level, Sequoyah 
4 Offsite and Onsite Damage Costs

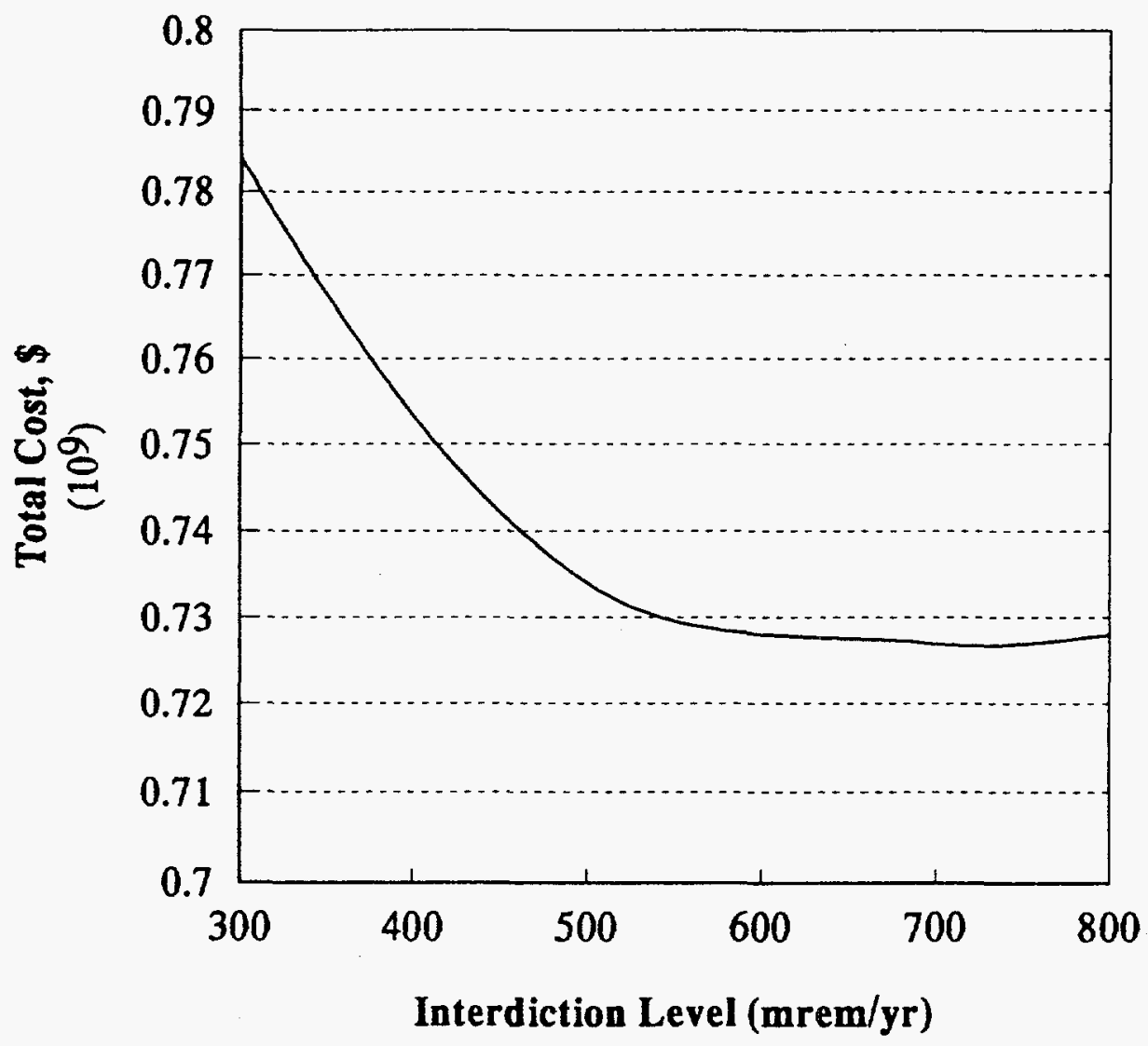

Figure 4-14 Total Cost at 50 Miles vs. Interdiction Level, Surry 
4 Offsite and Onsite Damage Costs

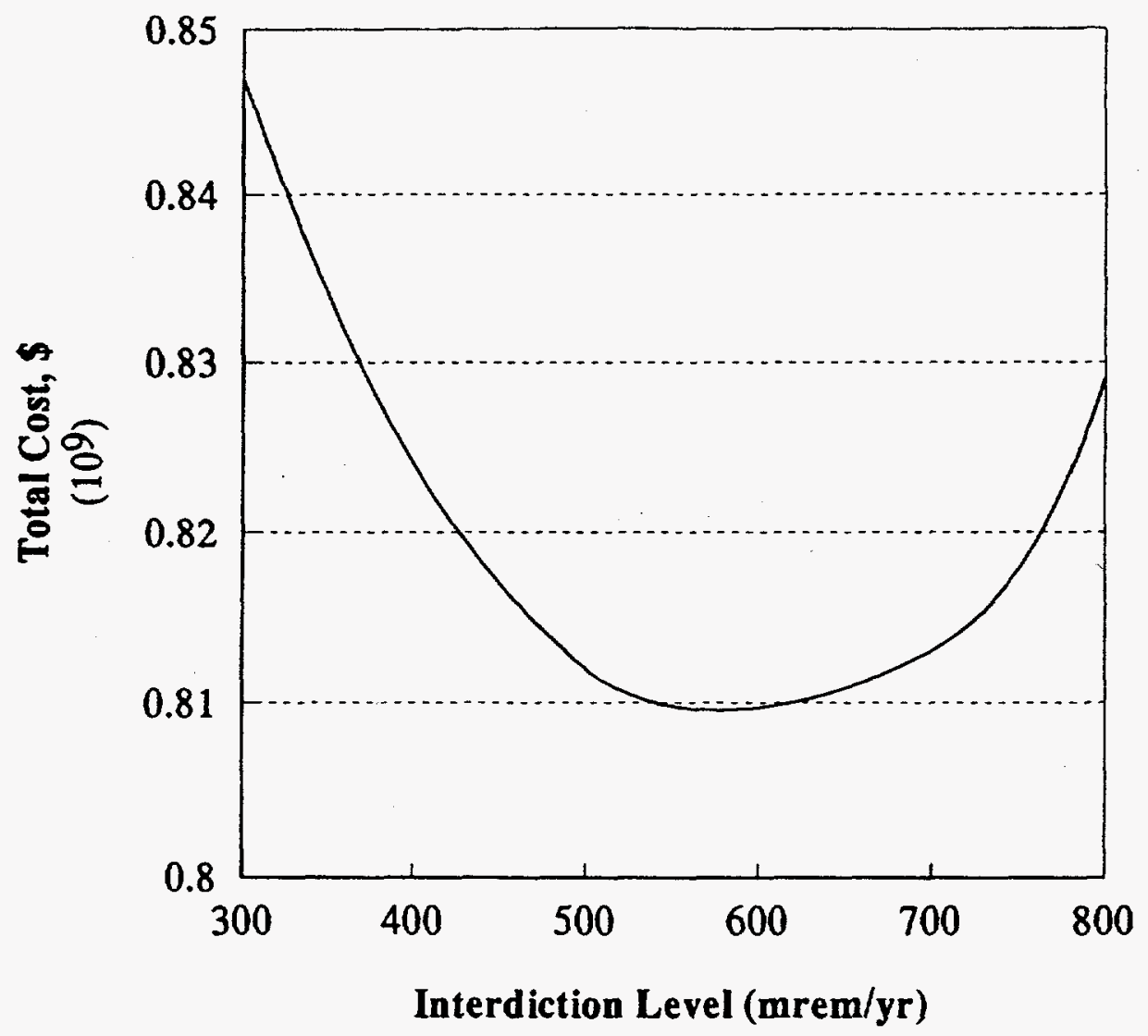

Figure 4-15 Total Cost at 50 Miles vs. Interdiction Level, Zion 
4 Offsite and Onsite Damage Costs

Table 4-1 Grand Gulf Consequences to 10 Miles

\begin{tabular}{|c|c|c|c|c|c|}
\hline $\begin{array}{c}\text { Source } \\
\text { Term }\end{array}$ & $\begin{array}{c}\text { Mean } \\
\text { Frequency } \\
(/ y r)\end{array}$ & $\begin{array}{c}\text { Early } \\
\text { Fatalities }\end{array}$ & $\begin{array}{c}\text { Latent } \\
\text { Fatalities }\end{array}$ & $\begin{array}{c}\text { Population } \\
\text { Dose } \\
\text { (Per-rem) }\end{array}$ & $\begin{array}{l}\text { Offsite } \\
\text { Costs } \\
(\$)\end{array}$ \\
\hline GG01-1 & $1.50 \mathrm{E}-08$ & 8.31E-06 & $1.47 \mathrm{E}+00$ & $4.03 \mathrm{E}+03$ & $1.32 \mathrm{E}+06$ \\
\hline GG01-2 & 4.30E-08 & $0.00 \mathrm{E}+00$ & $1.24 \mathrm{E}+00$ & $3.71 \mathrm{E}+03$ & $7.19 \mathrm{E}+05$ \\
\hline GG02-1 & $8.48 \mathrm{E}-08$ & $1.44 \mathrm{E}-04$ & $3.57 \mathrm{E}+00$ & $9.21 \mathrm{E}+03$ & $1.11 \mathrm{E}+07$ \\
\hline GG02-2 & $8.52 \mathrm{E}-08$ & $3.77 \mathrm{E}-06$ & $2.95 E+00$ & $7.29 \mathrm{E}+03$ & $1.15 \mathrm{E}+07$ \\
\hline GG03-1 & $1.21 \mathrm{E}-07$ & $2.09 \mathrm{E}-05$ & $3.86 \mathrm{E}+00$ & $9.24 \mathrm{E}+03$ & $2.15 \mathrm{E}+07$ \\
\hline GG03-2 & $5.89 \mathrm{E}-08$ & $1.18 \mathrm{E}-05$ & $4.48 \mathrm{E}+00$ & $1.06 \mathrm{E}+04$ & $2.36 \mathrm{E}+07$ \\
\hline GG04-1 & $9.53 \mathrm{E}-08$ & $6.72 \mathrm{E}-07$ & $3.08 \mathrm{E}+00$ & $7.73 \mathrm{E}+03$ & $1.37 \mathrm{E}+07$ \\
\hline GG04-2 & $2.47 \mathrm{E}-08$ & $1.15 \mathrm{E}-06$ & $4.35 \mathrm{E}+00$ & $1.03 \mathrm{E}+04$ & $1.60 \mathrm{E}+07$ \\
\hline GG05-1 & $1.07 \mathrm{E}-07$ & $2.08 \mathrm{E}-03$ & $6.43 E+00$ & $1.52 \mathrm{E}+04$ & $2.96 \mathrm{E}+07$ \\
\hline GG05-2 & $7.33 \mathrm{E}-08$ & $5.23 \mathrm{E}-04$ & $8.85 E+00$ & $1.94 \mathrm{E}+04$ & $4.05 \mathrm{E}+07$ \\
\hline GG06-1 & $1.58 \mathrm{E}-07$ & $5.15 \mathrm{E}-05$ & $8.08 \mathrm{E}+00$ & $1.79 \mathrm{E}+04$ & $3.51 \mathrm{E}+07$ \\
\hline GG06-2 & $6.20 \mathrm{E}-08$ & $1.11 \mathrm{E}-05$ & $8.63 E+00$ & $1.95 \mathrm{E}+04$ & $3.87 \mathrm{E}+07$ \\
\hline GG07-1 & $4.79 \mathrm{E}-07$ & $2.89 \mathrm{E}-05$ & $6.08 \mathrm{E}+00$ & $1.36 \mathrm{E}+04$ & $2.78 \mathrm{E}+07$ \\
\hline GG07-2 & $1.08 \mathrm{E}-08$ & 4.02E-07 & $8.27 \mathrm{E}+00$ & $1.86 \mathrm{E}+04$ & $4.02 E+07$ \\
\hline GG08-1 & $2.21 \mathrm{E}-07$ & $4.49 \mathrm{E}-03$ & $1.88 \mathrm{E}+01$ & $3.71 \mathrm{E}+04$ & $6.77 \mathrm{E}+07$ \\
\hline GG08-2 & $1.39 \mathrm{E}-07$ & $1.21 \mathrm{E}-03$ & $1.86 \mathrm{E}+01$ & $3.58 \mathrm{E}+04$ & $7.15 \mathrm{E}+07$ \\
\hline GG09-1 & $1.55 \mathrm{E}-07$ & $9.20 \mathrm{E}-05$ & $1.37 \mathrm{E}+01$ & $2.93 E+04$ & $6.19 \mathrm{E}+07$ \\
\hline GG09-2 & $3.53 \mathrm{E}-08$ & $7.31 \mathrm{E}-05$ & $1.03 E+01$ & $2.20 \mathrm{E}+04$ & $5.45 \mathrm{E}+07$ \\
\hline GG10-1 & $2.06 \mathrm{E}-07$ & $9.55 \mathrm{E}-06$ & $1.37 \mathrm{E}+01$ & $3.01 \mathrm{E}+04$ & $5.66 \mathrm{E}+07$ \\
\hline GG11-1 & 3.53E-08 & $4.52 \mathrm{E}-02$ & $4.94 \mathrm{E}+01$ & $9.12 \mathrm{E}+04$ & $1.00 \mathrm{E}+08$ \\
\hline GG11-2 & 7.47E-08 & $2.18 \mathrm{E}-02$ & $4.26 \mathrm{E}+01$ & $7.78 \mathrm{E}+04$ & $9.44 \mathrm{E}+07$ \\
\hline GG12-1 & $3.60 \mathrm{E}-08$ & $5.10 \mathrm{E}-03$ & $3.46 \mathrm{E}+01$ & $6.36 \mathrm{E}+04$ & $8.97 \mathrm{E}+07$ \\
\hline GG12-2 & $5.70 \mathrm{E}-08$ & $1.60 \mathrm{E}-03$ & $2.67 \mathrm{E}+01$ & $5.21 \mathrm{E}+04$ & $9.00 \mathrm{E}+07$ \\
\hline GG15-1 & $3.30 \mathrm{E}-07$ & $0.00 \mathrm{E}+00$ & $4.98 \mathrm{E}-03$ & $3.47 \mathrm{E}+01$ & $1.04 \mathrm{E}+02$ \\
\hline GG16-1 & $3.80 \mathrm{E}-07$ & $0.00 \mathrm{E}+00$ & $6.05 \mathrm{E}-02$ & $6.25 \mathrm{E}+02$ & $5.72 \mathrm{E}+04$ \\
\hline GG17-1 & $1.76 \mathrm{E}-07$ & $0.00 \mathrm{E}+00$ & $7.28 \mathrm{E}-01$ & $2.05 \mathrm{E}+03$ & $2.36 \mathrm{E}+05$ \\
\hline GG18-1 & $4.96 \mathrm{E}-07$ & $0.00 \mathrm{E}+00$ & $2.85 \mathrm{E}+00$ & $7.15 \mathrm{E}+03$ & $5.09 \mathrm{E}+06$ \\
\hline GG18-2 & $2.44 \mathrm{E}-08$ & $0.00 \mathrm{E}+00$ & $3.24 \mathrm{E}+00$ & $7.70 \mathrm{E}+03$ & $8.55 \mathrm{E}+06$ \\
\hline GG19-1 & $1.63 \mathrm{E}-07$ & $0.00 \mathrm{E}+00$ & $5.54 \mathrm{E}+00$ & $1.27 \mathrm{E}+04$ & $2.33 \mathrm{E}+07$ \\
\hline GG19-2 & 1.73E-08 & $0.00 \mathrm{E}+00$ & $7.38 \mathrm{E}+00$ & $1.68 \mathrm{E}+04$ & $2.82 \mathrm{E}+07$ \\
\hline
\end{tabular}


4 Offsite and Onsite Damage Costs

Table 4-2 Grand Gulf Consequences to 50 Miles

\begin{tabular}{|c|c|c|c|c|c|}
\hline $\begin{array}{l}\text { Source } \\
\text { Term }\end{array}$ & $\begin{array}{c}\text { Mean } \\
\text { Frequency } \\
(/ \mathbf{y r})\end{array}$ & $\begin{array}{c}\text { Early } \\
\text { Fatalities }\end{array}$ & $\begin{array}{c}\text { Latent } \\
\text { Fatalities }\end{array}$ & $\begin{array}{c}\text { Population } \\
\text { Dose } \\
\text { (Per-rem) }\end{array}$ & $\begin{array}{c}\text { Offsite } \\
\text { Costs } \\
(\$)\end{array}$ \\
\hline GG01-1 & $1.50 \mathrm{E}-08$ & $8.31 \mathrm{E}-06$ & $6.97 \mathrm{E}+00$ & $2.13 E+04$ & $1.48 \mathrm{E}+06$ \\
\hline GG01-2 & $4.30 \mathrm{E}-08$ & $0.00 \mathrm{E}+00$ & $7.17 \mathrm{E}+00$ & $2.31 E+04$ & $9.98 \mathrm{E}+05$ \\
\hline GG02-1 & $8.48 \mathrm{E}-08$ & $1.44 \mathrm{E}-04$ & $2.75 \mathrm{E}+01$ & $7.62 \mathrm{E}+04$ & $1.82 E+07$ \\
\hline GG02-2 & $8.52 \mathrm{E}-08$ & $3.77 \mathrm{E}-06$ & $3.38 \mathrm{E}+01$ & $8.98 \mathrm{E}+04$ & $2.13 E+07$ \\
\hline GG03-1 & $1.21 \mathrm{E}-07$ & $2.09 \mathrm{E}-05$ & $4.87 E+01$ & $1.34 \mathrm{E}+0.5$ & $7.38 E+07$ \\
\hline GG03-2 & $5.89 \mathrm{E}-08$ & $1.18 \mathrm{E}-05$ & $7.01 \mathrm{E}+01$ & $1.72 \mathrm{E}+05$ & $7.24 \mathrm{E}+07$ \\
\hline GG04-1 & $9.53 \mathrm{E}-08$ & $6.72 \mathrm{E}-07$ & $3.60 \mathrm{E}+01$ & $1.03 E+05$ & $4.32 \mathrm{E}+07$ \\
\hline GG04-2 & $2.47 \mathrm{E}-08$ & $1.15 \mathrm{E}-06$ & $4.92 \mathrm{E}+01$ & $1.26 \mathrm{E}+05$ & $3.77 \mathrm{E}+07$ \\
\hline GG05-1 & $1.07 \mathrm{E}-07$ & $2.08 \mathrm{E}-03$ & $8.34 \mathrm{E}+01$ & $2.53 \mathrm{E}+05$ & $1.76 \mathrm{E}+08$ \\
\hline GG05-2 & 7.33E-08 & $5.23 \mathrm{E}-04$ & $1.07 \mathrm{E}+02$ & $2.64 \mathrm{E}+05$ & $2.65 \mathrm{E}+08$ \\
\hline GG06-1 & $1.58 \mathrm{E}-07$ & $5.15 \mathrm{E}-05$ & $9.41 \mathrm{E}+01$ & $2.34 \mathrm{E}+05$ & $1.95 \mathrm{E}+08$ \\
\hline GG06-2 & $6.20 \mathrm{E}-08$ & $1.11 \mathrm{E}-05$ & $1.28 \mathrm{E}+02$ & $2.96 \mathrm{E}+05$ & $1.48 \mathrm{E}+08$ \\
\hline GG07-1 & 4.79E-07 & $2.89 \mathrm{E}-05$ & $7.38 \mathrm{E}+01$ & $1.86 \mathrm{E}+05$ & $2.07 \mathrm{E}+08$ \\
\hline GG07-2 & $1.08 \mathrm{E}-08$ & 4.02E-07 & $1.32 \mathrm{E}+02$ & $3.05 \mathrm{E}+05$ & $1.80 \mathrm{E}+08$ \\
\hline GG08-1 & $2.21 \mathrm{E}-07$ & $4.49 \mathrm{E}-03$ & $1.48 \mathrm{E}+02$ & $3.61 \mathrm{E}+05$ & $4.39 \mathrm{E}+08$ \\
\hline GG08-2 & $1.39 \mathrm{E}-07$ & $1.21 \mathrm{E}-03$ & $1.78 \mathrm{E}+02$ & $4.21 E+05$ & $6.09 E+08$ \\
\hline GG09-1 & $1.55 \mathrm{E}-07$ & $9.20 \mathrm{E}-05$ & $1.64 \mathrm{E}+02$ & $3.82 \mathrm{E}+05$ & $4.39 E+08$ \\
\hline GG09-2 & $3.53 \mathrm{E}-08$ & $7.31 \mathrm{E}-05$ & $1.42 \mathrm{E}+02$ & $3.31 \mathrm{E}+05$ & $3.71 E+08$ \\
\hline GG10-1 & $2.06 \mathrm{E}-07$ & $9.55 \mathrm{E}-06$ & $2.01 \mathrm{E}+02$ & $4.55 \mathrm{E}+05$ & $3.12 \mathrm{E}+08$ \\
\hline GG11-1 & $3.53 \mathrm{E}-08$ & $4.52 \mathrm{E}-02$ & $2.42 \mathrm{E}+02$ & $5.66 \mathrm{E}+05$ & $8.14 E+08$ \\
\hline GG11-2 & 7.47E-08 & $2.18 \mathrm{E}-02$ & $3.10 \mathrm{E}+02$ & $6.99 \mathrm{E}+05$ & $9.95 \mathrm{E}+08$ \\
\hline GG12-1 & $3.60 \mathrm{E}-08$ & $5.10 \mathrm{E}-03$ & $2.18 \mathrm{E}+02$ & $5.09 \mathrm{E}+05$ & $7.63 E+08$ \\
\hline GG12-2 & $5.70 \mathrm{E}-08$ & $1.60 \mathrm{E}-03$ & $2.38 \mathrm{E}+02$ & $5.60 \mathrm{E}+05$ & $8.25 \mathrm{E}+08$ \\
\hline GG15-1 & $3.30 \mathrm{E}-07$ & $0.00 \mathrm{E}+00$ & $8.60 \mathrm{E}-03$ & $5.67 \mathrm{E}+01$ & $1.04 \mathrm{E}+02$ \\
\hline GG16-1 & $3.80 \mathrm{E}-07$ & $0.00 \mathrm{E}+00$ & $2.77 \mathrm{E}-01$ & $2.98 \mathrm{E}+03$ & $5.88 \mathrm{E}+04$ \\
\hline GG17-1 & $1.76 \mathrm{E}-07$ & $0.00 \mathrm{E}+00$ & $3.44 \mathrm{E}+00$ & $1.18 \mathrm{E}+04$ & $2.74 \mathrm{E}+05$ \\
\hline GG18-1 & $4.96 \mathrm{E}-07$ & $0.00 \mathrm{E}+00$ & $2.54 \mathrm{E}+01$ & $7.02 E+04$ & $1.06 \mathrm{E}+07$ \\
\hline GG18-2 & $2.44 \mathrm{E}-08$ & $0.00 \mathrm{E}+00$ & $2.87 \mathrm{E}+01$ & $7.42 \mathrm{E}+04$ & $1.32 \mathrm{E}+07$ \\
\hline GG19-1 & $1.63 \mathrm{E}-07$ & $0.00 \mathrm{E}+00$ & $9.19 \mathrm{E}+01$ & $2.12 E+05$ & $8.87 \mathrm{E}+07$ \\
\hline GG19-2 & $1.73 \mathrm{E}-08$ & $0.00 \mathrm{E}+00$ & $1.05 \mathrm{E}+02$ & $2.38 \mathrm{E}+05$ & $8.44 \mathrm{E}+07$ \\
\hline
\end{tabular}


4 Offsite and Onsite Damage Costs

Table 4-3 Grand Gulf Consequences to 100 Miles

\begin{tabular}{|c|c|c|c|c|c|}
\hline $\begin{array}{l}\text { Source } \\
\text { Term }\end{array}$ & $\begin{array}{c}\text { Mean } \\
\text { Frequency } \\
(/ \mathbf{y r})\end{array}$ & $\begin{array}{c}\text { Early } \\
\text { Fatalities }\end{array}$ & $\begin{array}{l}\text { Latent } \\
\text { Fatalities }\end{array}$ & $\begin{array}{c}\text { Population } \\
\text { Dose } \\
\text { (Per-Rem) }\end{array}$ & $\begin{array}{c}\text { Offisite } \\
\text { Costs } \\
(\$)\end{array}$ \\
\hline GG01-1 & $1.50 \mathrm{E}-08$ & 8.31E-06 & $1.07 \mathrm{E}+01$ & $3.45 \mathrm{E}+04$ & $1.49 \mathrm{E}+06$ \\
\hline GG01-2 & $4.30 \mathrm{E}-08$ & $0.00 \mathrm{E}+00$ & $1.15 \mathrm{E}+01$ & $3.88 \mathrm{E}+04$ & $1.00 \mathrm{E}+06$ \\
\hline GG02-1 & $8.48 \mathrm{E}-08$ & $1.44 \mathrm{E}-04$ & $5.40 \mathrm{E}+01$ & $1.56 \mathrm{E}+05$ & $1.93 \mathrm{E}+07$ \\
\hline GG02-2 & $8.52 \mathrm{E}-08$ & $3.77 \mathrm{E}-06$ & $7.08 \mathrm{E}+01$ & $1.95 \mathrm{E}+05$ & $2.25 \mathrm{E}+07$ \\
\hline GG03-1 & $1.21 \mathrm{E}-07$ & $2.09 \mathrm{E}-05$ & $1.15 E+02$ & $3.25 \mathrm{E}+05$ & $9.47 \mathrm{E}+07$ \\
\hline GG03-2 & $5.89 \mathrm{E}-08$ & $1.18 \mathrm{E}-05$ & $1.61 \mathrm{E}+02$ & $4.03 E+05$ & $7.97 \mathrm{E}+07$ \\
\hline GG04-1 & 9.53E-08 & $6.72 \mathrm{E}-07$ & $8.59 \mathrm{E}+01$ & $2.44 \mathrm{E}+05$ & $5.73 E+07$ \\
\hline GG04-2 & 2.47E-08 & $1.15 \mathrm{E}-06$ & $1.09 \mathrm{E}+02$ & $2.90 \mathrm{E}+05$ & $4.40 \mathrm{E}+07$ \\
\hline GG05-1 & $1.07 \mathrm{E}-07$ & $2.08 \mathrm{E}-03$ & $2.17 \mathrm{E}+02$ & $6.59 \mathrm{E}+05$ & $2.52 \mathrm{E}+08$ \\
\hline GG05-2 & $7.33 \mathrm{E}-08$ & $5.23 \mathrm{E}-04$ & $2.89 \mathrm{E}+02$ & $7.33 \mathrm{E}+05$ & $4.44 \mathrm{E}+08$ \\
\hline GG06-1 & $1.58 \mathrm{E}-07$ & 5.15E-05 & $2.61 \mathrm{E}+02$ & $6.52 \mathrm{E}+05$ & $3.11 \mathrm{E}+08$ \\
\hline GG06-2 & $6.20 \mathrm{E}-08$ & $1.11 \mathrm{E}-05$ & $3.45 \mathrm{E}+02$ & $7.96 \mathrm{E}+05$ & $1.85 \mathrm{E}+08$ \\
\hline GG07-1 & $4.79 \mathrm{E}-07$ & $2.89 \mathrm{E}-05$ & $2.00 \mathrm{E}+02$ & $5.10 \mathrm{E}+05$ & $4.31 E+08$ \\
\hline GG07-2 & $1.08 \mathrm{E}-08$ & $4.02 \mathrm{E}-07$ & $3.83 E+02$ & $8.79 \mathrm{E}+05$ & $2.32 \mathrm{E}+08$ \\
\hline GG08-1 & $2.21 \mathrm{E}-07$ & $4.49 \mathrm{E}-03$ & $4.51 \mathrm{E}+02$ & $1.10 \mathrm{E}+06$ & $7.83 E+08$ \\
\hline GG08-2 & $1.39 \mathrm{E}-07$ & $1.21 \mathrm{E}-03$ & $5.83 E+02$ & $1.39 E+06$ & $1.24 \mathrm{E}+09$ \\
\hline GG09-1 & $1.55 \mathrm{E}-07$ & $9.20 \mathrm{E}-05$ & $5.54 \mathrm{E}+02$ & $1.29 \mathrm{E}+06$ & $8.55 E+08$ \\
\hline GG09-2 & $3.53 \mathrm{E}-08$ & $7.31 \mathrm{E}-05$ & $5.05 \mathrm{E}+02$ & $1.16 \mathrm{E}+06$ & $6.03 E+08$ \\
\hline GG10-1 & $2.06 \mathrm{E}-07$ & $9.55 \mathrm{E}-06$ & $6.24 \mathrm{E}+02$ & $1.41 \mathrm{E}+06$ & $4.51 \mathrm{E}+08$ \\
\hline GG11-1 & $3.53 \mathrm{E}-08$ & $4.52 \mathrm{E}-02$ & $6.82 \mathrm{E}+02$ & $1.63 E+06$ & $1.97 \mathrm{E}+09$ \\
\hline GG11-2 & $7.47 \mathrm{E}-08$ & $2.18 \mathrm{E}-02$ & $8.78 \mathrm{E}+02$ & $2.07 \mathrm{E}+06$ & $2.62 \mathrm{E}+09$ \\
\hline GG12-1 & $3.60 \mathrm{E}-08$ & $5.10 \mathrm{E}-03$ & $6.32 \mathrm{E}+02$ & $1.52 \mathrm{E}+06$ & $1.94 \mathrm{E}+09$ \\
\hline GG12-2 & $5.70 \mathrm{E}-08$ & $1.60 \mathrm{E}-03$ & $7.95 \mathrm{E}+02$ & $1.87 \mathrm{E}+06$ & $1.93 E+09$ \\
\hline GG15-1 & $3.30 \mathrm{E}-07$ & $0.00 \mathrm{E}+00$ & $1.12 \mathrm{E}-02$ & $6.99 E+01$ & $1.04 \mathrm{E}+02$ \\
\hline GG16-1 & $3.80 \mathrm{E}-07$ & $0.00 \mathrm{E}+00$ & $4.13 \mathrm{E}-01$ & $4.39 E+03$ & $5.88 \mathrm{E}+04$ \\
\hline GG17-1 & $1.76 \mathrm{E}-07$ & $0.00 \mathrm{E}+00$ & $5.51 \mathrm{E}+00$ & $1.95 \mathrm{E}+04$ & $2.74 \mathrm{E}+05$ \\
\hline GG18-1 & $4.96 \mathrm{E}-07$ & $0.00 \mathrm{E}+00$ & $5.44 \mathrm{E}+01$ & $1.59 \mathrm{E}+05$ & $1.09 \mathrm{E}+07$ \\
\hline GG18-2 & $2.44 \mathrm{E}-08$ & $0.00 \mathrm{E}+00$ & $5.59 \mathrm{E}+01$ & $1.53 \mathrm{E}+05$ & $1.36 \mathrm{E}+07$ \\
\hline GG19-1 & $1.63 \mathrm{E}-07$ & $0.00 \mathrm{E}+00$ & $2.40 \mathrm{E}+02$ & $5.48 \mathrm{E}+05$ & $1.13 \mathrm{E}+08$ \\
\hline GG19-2 & $1.73 \mathrm{E}-08$ & $0.00 \mathrm{E}+00$ & $2.80 \mathrm{E}+02$ & $6.26 \mathrm{E}+0.5$ & $9.83 \mathrm{E}+07$ \\
\hline
\end{tabular}


4 Offsite and Onsite Damage Costs

Table 4-4 Grand Gulf Consequences to 1000 Miles

\begin{tabular}{|c|c|c|c|c|c|}
\hline $\begin{array}{c}\text { Source } \\
\text { Term }\end{array}$ & $\begin{array}{c}\text { Mean } \\
\text { Frequency } \\
(/ \mathbf{y r})\end{array}$ & $\begin{array}{c}\text { Early } \\
\text { Fatalities }\end{array}$ & $\begin{array}{c}\text { Latent } \\
\text { Fatalities }\end{array}$ & $\begin{array}{c}\text { Population } \\
\text { Dose } \\
\text { (Per-Rem) } \\
\end{array}$ & $\begin{array}{c}\text { Offsite } \\
\text { Costs } \\
(\$) \\
\end{array}$ \\
\hline GG01-1 & $1.50 \mathrm{E}-08$ & $8.31 \mathrm{E}-06$ & $1.81 \mathrm{E}+01$ & $5.78 \mathrm{E}+04$ & $1.49 E+06$ \\
\hline GG01-2 & $4.30 \mathrm{E}-08$ & $0.00 \mathrm{E}+00$ & $2.00 \mathrm{E}+01$ & $6.52 \mathrm{E}+04$ & $1.00 \mathrm{E}+06$ \\
\hline GG02-1 & $8.48 \mathrm{E}-08$ & $1.44 \mathrm{E}-04$ & $1.03 \mathrm{E}+02$ & $3.20 \mathrm{E}+05$ & $1.93 \mathrm{E}+07$ \\
\hline GG02-2 & $8.52 \mathrm{E}-08$ & 3.77E-06 & $1.46 \mathrm{E}+02$ & $4.27 \mathrm{E}+05$ & $2.25 \mathrm{E}+07$ \\
\hline GG03-1 & $1.21 \mathrm{E}-07$ & $2.09 \mathrm{E}-05$ & $3.43 \mathrm{E}+02$ & $1.08 \mathrm{E}+06$ & $1.01 \mathrm{E}+08$ \\
\hline GG03-2 & $5.89 \mathrm{E}-08$ & $1.18 \mathrm{E}-05$ & $3.72 \mathrm{E}+02$ & $9.79 \mathrm{E}+05$ & $8.01 \mathrm{E}+07$ \\
\hline GG04-1 & $9.53 \mathrm{E}-08$ & $6.72 \mathrm{E}-07$ & $2.64 \mathrm{E}+02$ & $8.29 \mathrm{E}+05$ & $6.01 \mathrm{E}+07$ \\
\hline GG04-2 & $2.47 \mathrm{E}-08$ & $1.15 \mathrm{E}-06$ & $2.65 \mathrm{E}+02$ & $7.75 \mathrm{E}+05$ & $4.46 \mathrm{E}+07$ \\
\hline GG05-1 & $1.07 \mathrm{E}-07$ & $2.08 \mathrm{E}-03$ & $6.95 E+02$ & $2.42 \mathrm{E}+06$ & $3.48 \mathrm{E}+08$ \\
\hline GG05-2 & $7.33 \mathrm{E}-08$ & $5.23 \mathrm{E}-04$ & $8.98 \mathrm{E}+02$ & $2.39 \mathrm{E}+06$ & $5.05 \mathrm{E}+08$ \\
\hline GG06-1 & $1.58 \mathrm{E}-07$ & $5.15 \mathrm{E}-05$ & $9.87 \mathrm{E}+02$ & $2.49 \mathrm{E}+06$ & $3.68 \mathrm{E}+08$ \\
\hline GG06-2 & $6.20 \mathrm{E}-08$ & $1.11 \mathrm{E}-05$ & $1.12 \mathrm{E}+03$ & $2.57 \mathrm{E}+06$ & $1.99 \mathrm{E}+08$ \\
\hline GG07-1 & $4.79 \mathrm{E}-07$ & $2.89 \mathrm{E}-05$ & $1.02 \mathrm{E}+03$ & $2.60 \mathrm{E}+06$ & $5.38 \mathrm{E}+08$ \\
\hline GG07-2 & $1.08 \mathrm{E}-08$ & $4.02 \mathrm{E}-07$ & $1.26 \mathrm{E}+03$ & $2.84 \mathrm{E}+06$ & $2.45 \mathrm{E}+08$ \\
\hline GG08-1 & $2.21 \mathrm{E}-07$ & $4.49 \mathrm{E}-03$ & $1.95 \mathrm{E}+03$ & $4.70 \mathrm{E}+06$ & $9.39 \mathrm{E}+08$ \\
\hline GG08-2 & $1.39 \mathrm{E}-07$ & $1.21 \mathrm{E}-03$ & $2.87 E+03$ & $6.67 \mathrm{E}+06$ & $1.71 \mathrm{E}+09$ \\
\hline GG09-1 & $1.55 \mathrm{E}-07$ & $9.20 \mathrm{E}-05$ & $2.83 E+03$ & $6.33 E+06$ & $1.13 E+09$ \\
\hline GG09-2 & $3.53 \mathrm{E}-08$ & $7.31 \mathrm{E}-05$ & $2.13 E+03$ & $4.74 \mathrm{E}+06$ & $7.48 \mathrm{E}+08$ \\
\hline GG10-1 & $2.06 \mathrm{E}-07$ & $9.55 \mathrm{E}-06$ & $2.45 \mathrm{E}+03$ & $5.42 \mathrm{E}+06$ & $5.21 \mathrm{E}+08$ \\
\hline GG11-1 & $3.53 \mathrm{E}-08$ & $4.52 \mathrm{E}-02$ & $4.16 \mathrm{E}+03$ & $9.65 \mathrm{E}+06$ & $3.39 \mathrm{E}+09$ \\
\hline GG11-2 & $7.47 \mathrm{E}-08$ & $2.18 \mathrm{E}-02$ & $5.73 \mathrm{E}+03$ & $1.32 E+07$ & $4.74 \mathrm{E}+09$ \\
\hline GG12-1 & $3.60 \mathrm{E}-08$ & $5.10 \mathrm{E}-03$ & $4.36 \mathrm{E}+03$ & $1.01 \mathrm{E}+07$ & $3.58 \mathrm{E}+09$ \\
\hline GG12-2 & $5.70 \mathrm{E}-08$ & $1.60 \mathrm{E}-03$ & $4.86 \mathrm{E}+03$ & $1.10 \mathrm{E}+07$ & $2.88 \mathrm{E}+09$ \\
\hline GG15-1 & $3.30 \mathrm{E}-07$ & $0.00 \mathrm{E}+00$ & $2.25 \mathrm{E}-02$ & $1.09 \mathrm{E}+02$ & $1.04 \mathrm{E}+02$ \\
\hline GG16-1 & $3.80 \mathrm{E}-07$ & $0.00 \mathrm{E}+00$ & $6.56 \mathrm{E}-01$ & $6.43 E+03$ & $5.88 \mathrm{E}+04$ \\
\hline GG17-1 & $1.76 \mathrm{E}-07$ & $0.00 \mathrm{E}+00$ & $1.01 \mathrm{E}+01$ & $3.47 \mathrm{E}+04$ & $2.74 \mathrm{E}+05$ \\
\hline GG18-1 & $4.96 \mathrm{E}-07$ & $0.00 \mathrm{E}+00$ & $1.15 \mathrm{E}+02$ & $3.65 \mathrm{E}+05$ & $1.10 \mathrm{E}+07$ \\
\hline GG18-2 & $2.44 \mathrm{E}-08$ & $0.00 \mathrm{E}+00$ & $1.02 E+02$ & $2.92 \mathrm{E}+05$ & $1.36 \mathrm{E}+07$ \\
\hline GG19-1 & $1.63 \mathrm{E}-07$ & $0.00 \mathrm{E}+00$ & $8.35 E+02$ & $1.88 \mathrm{E}+06$ & $1.19 E+08$ \\
\hline GG19-2 & $1.73 \mathrm{E}-08$ & $0.00 \mathrm{E}+00$ & $7.16 \mathrm{E}+02$ & $1.59 \mathrm{E}+06$ & $1.01 E+08$ \\
\hline
\end{tabular}


Table 4-5 Peach Bottom Consequences to 10 Miles

\begin{tabular}{|c|c|c|c|c|c|}
\hline $\begin{array}{l}\text { Source } \\
\text { Term }\end{array}$ & $\begin{array}{c}\text { Mean } \\
\text { Frequency } \\
\text { (/yr) }\end{array}$ & $\begin{array}{c}\text { Early } \\
\text { Fatalities }\end{array}$ & $\begin{array}{c}\text { Latent } \\
\text { Fatalities }\end{array}$ & $\begin{array}{c}\text { Population } \\
\text { Dose } \\
\text { (Per-rem) }\end{array}$ & $\begin{array}{c}\text { Ofisite } \\
\text { Costs } \\
(\$)\end{array}$ \\
\hline PB01-1 & $9.93 \mathrm{E}-08$ & $0.00 \mathrm{E}+00$ & $6.72 \mathrm{E}+00$ & $1.61 \mathrm{E}+04$ & $1.60 \mathrm{E}+07$ \\
\hline PB01-3 & $7.07 \mathrm{E}-08$ & $3.05 \mathrm{E}-06$ & $7.45 \mathrm{E}+00$ & $1.77 \mathrm{E}+04$ & $1.70 \mathrm{E}+07$ \\
\hline PB02-1 & $5.37 \mathrm{E}-08$ & $1.26 \mathrm{E}-03$ & $8.86 \mathrm{E}+00$ & $2.15 E+04$ & $5.41 E+07$ \\
\hline PB02-3 & $5.63 \mathrm{E}-08$ & $2.09 \mathrm{E}-03$ & $1.49 \mathrm{E}+01$ & $3.44 \mathrm{E}+04$ & $7.50 \mathrm{E}+07$ \\
\hline PB03-1 & 1.17E-07 & $1.77 \mathrm{E}-05$ & $9.46 \mathrm{E}+00$ & $2.25 \mathrm{E}+04$ & $5.56 \mathrm{E}+07$ \\
\hline PB03-3 & 1.13E-07 & $2.43 \mathrm{E}-05$ & $1.29 \mathrm{E}+01$ & $3.00 \mathrm{E}+04$ & $6.06 \mathrm{E}+07$ \\
\hline PB04-1 & $9.95 \mathrm{E}-08$ & $1.16 \mathrm{E}-07$ & $1.08 \mathrm{E}+01$ & $2.52 \mathrm{E}+04$ & $6.04 E+07$ \\
\hline PB04-3 & $2.05 \mathrm{E}-08$ & $7.52 \mathrm{E}-07$ & $1.36 \mathrm{E}+01$ & $3.02 E+04$ & $6.33 E+07$ \\
\hline PB05-1 & $8.62 \mathrm{E}-08$ & $2.41 \mathrm{E}-02$ & $1.83 \mathrm{E}+01$ & $4.32 E+04$ & $9.60 \mathrm{E}+07$ \\
\hline PB05-3 & $3.38 \mathrm{E}-08$ & $2.18 \mathrm{E}-02$ & $2.22 \mathrm{E}+01$ & $5.07 \mathrm{E}+04$ & $1.06 \mathrm{E}+08$ \\
\hline PB06-1 & $1.26 \mathrm{E}-07$ & $1.43 E-03$ & $2.31 \mathrm{E}+01$ & $4.97 \mathrm{E}+04$ & $1.20 \mathrm{E}+08$ \\
\hline PB06-3 & $2.43 \mathrm{E}-08$ & $1.72 \mathrm{E}-03$ & $2.87 \mathrm{E}+01$ & $6.16 \mathrm{E}+04$ & $1.39 E+08$ \\
\hline PB07-1 & $3.24 \mathrm{E}-07$ & $1.78 \mathrm{E}-04$ & $2.41 \mathrm{E}+01$ & $5.46 \mathrm{E}+04$ & $1.46 \mathrm{E}+08$ \\
\hline PB07-3 & $1.46 \mathrm{E}-07$ & $5.20 \mathrm{E}-04$ & $2.97 \mathrm{E}+01$ & $6.13 E+04$ & $1.28 \mathrm{E}+08$ \\
\hline PB08-1 & $7.54 \mathrm{E}-08$ & $3.18 \mathrm{E}-06$ & $2.54 \mathrm{E}+01$ & $5.60 \mathrm{E}+04$ & $1.56 \mathrm{E}+08$ \\
\hline PB09-1 & $7.60 \mathrm{E}-08$ & $1.63 \mathrm{E}-02$ & $6.34 \mathrm{E}+01$ & $1.13 \mathrm{E}+05$ & $2.40 \mathrm{E}+08$ \\
\hline PB09-3 & $1.60 \mathrm{E}-08$ & 4.73E-02 & $5.80 \mathrm{E}+01$ & $1.08 \mathrm{E}+05$ & $2.22 \mathrm{E}+08$ \\
\hline PB10-1 & $1.70 \mathrm{E}-07$ & $1.61 \mathrm{E}-03$ & $4.63 \mathrm{E}+01$ & $8.98 \mathrm{E}+04$ & $2.53 E+08$ \\
\hline PB11-1 & $1.95 \mathrm{E}-07$ & $9.11 \mathrm{E}-05$ & $3.18 \mathrm{E}+01$ & $6.70 \mathrm{E}+04$ & $2.30 \mathrm{E}+08$ \\
\hline PB12-1 & $5.63 \mathrm{E}-08$ & $6.71 \mathrm{E}-02$ & $2.03 E+02$ & $3.46 \mathrm{E}+05$ & $4.04 E+08$ \\
\hline PB13-1 & $2.45 \mathrm{E}-07$ & $2.71 \mathrm{E}-02$ & 1.37E+02 & $2.31 E+05$ & $3.65 \mathrm{E}+08$ \\
\hline PB13-3 & $1.48 \mathrm{E}-08$ & $1.32 \mathrm{E}-02$ & $1.16 \mathrm{E}+02$ & $1.99 \mathrm{E}+05$ & $3.10 \mathrm{E}+08$ \\
\hline PB14-1 & $6.04 \mathrm{E}-07$ & $2.11 \mathrm{E}-03$ & $5.72 \mathrm{E}+01$ & $1.12 \mathrm{E}+05$ & $3.23 \mathrm{E}+08$ \\
\hline PB16-1 & $4.31 \mathrm{E}-08$ & $2.13 \mathrm{E}-01$ & $3.82 \mathrm{E}+02$ & $6.08 \mathrm{E}+05$ & 4.57E+08 \\
\hline PB17-1 & $3.70 \mathrm{E}-07$ & $0.00 \mathrm{E}+00$ & $2.54 \mathrm{E}-03$ & $2.21 \mathrm{E}+01$ & $2.23 E+02$ \\
\hline PB18-1 & $6.90 \mathrm{E}-07$ & $0.00 \mathrm{E}+00$ & $1.16 \mathrm{E}-01$ & $6.99 \mathrm{E}+02$ & $2.52 \mathrm{E}+05$ \\
\hline PB19-1 & $3.26 \mathrm{E}-07$ & $0.00 \mathrm{E}+00$ & $1.04 \mathrm{E}+01$ & $2.43 E+04$ & $5.52 \mathrm{E}+07$ \\
\hline PB19-3 & $2.45 \mathrm{E}-08$ & $0.00 \mathrm{E}+00$ & $9.01 \mathrm{E}+00$ & $2.09 \mathrm{E}+04$ & $1.78 \mathrm{E}+07$ \\
\hline
\end{tabular}


4 Offsite and Onsite Damage Costs

Table 4-6 Peach Bottom Consequences to 50 Miles

\begin{tabular}{|c|c|c|c|c|c|}
\hline $\begin{array}{l}\text { Source } \\
\text { Term }\end{array}$ & $\begin{array}{c}\text { Mean } \\
\text { Frequency } \\
(\text { yr })\end{array}$ & $\begin{array}{c}\text { Early } \\
\text { Fatalities }\end{array}$ & $\begin{array}{c}\text { Latent } \\
\text { Fatalities }\end{array}$ & $\begin{array}{c}\text { Population } \\
\text { Dose } \\
\text { (Per-rem) }\end{array}$ & $\begin{array}{l}\text { Offsite } \\
\text { Costs } \\
(\$)\end{array}$ \\
\hline PB01-1 & $9.93 \mathrm{E}-08$ & $0.00 \mathrm{E}+00$ & $7.94 \mathrm{E}+01$ & $2.05 \mathrm{E}+05$ & $2.40 \mathrm{E}+07$ \\
\hline PB01-3 & 7.07E-08 & $3.05 \mathrm{E}-06$ & $6.12 \mathrm{E}+01$ & $1.57 \mathrm{E}+05$ & $2.18 \mathrm{E}+07$ \\
\hline PB02-1 & 5.37E-08 & $1.26 \mathrm{E}-03$ & $2.85 \mathrm{E}+02$ & $8.85 \mathrm{E}+05$ & $2.12 \mathrm{E}+08$ \\
\hline PB02-3 & $5.63 \mathrm{E}-08$ & $2.09 \mathrm{E}-03$ & $3.32 \mathrm{E}+02$ & $9.38 \mathrm{E}+05$ & $2.45 \mathrm{E}+08$ \\
\hline PB03-1 & $1.17 \mathrm{E}-07$ & $1.77 \mathrm{E}-05$ & $2.51 \mathrm{E}+02$ & $6.73 \mathrm{E}+05$ & $2.36 \mathrm{E}+08$ \\
\hline PB03-3 & 1.13E-07 & $2.43 \mathrm{E}-05$ & $2.18 \mathrm{E}+02$ & $5.63 \mathrm{E}+05$ & $1.29 E+08$ \\
\hline PB04-1 & 9.95E-08 & $1.16 \mathrm{E}-07$ & $3.24 \mathrm{E}+02$ & $8.05 E+05$ & $2.72 \mathrm{E}+08$ \\
\hline PB04-3 & $2.05 \mathrm{E}-08$ & $7.52 \mathrm{E}-07$ & $2.81 \mathrm{E}+02$ & $6.83 \mathrm{E}+05$ & $2.96 \mathrm{E}+08$ \\
\hline PB05-1 & $8.62 \mathrm{E}-08$ & $2.41 \mathrm{E}-02$ & $7.90 \mathrm{E}+02$ & $2.54 \mathrm{E}+06$ & $1.29 \mathrm{E}+09$ \\
\hline PB05-3 & $3.38 \mathrm{E}-08$ & $2.18 \mathrm{E}-02$ & $6.56 \mathrm{E}+02$ & $2.01 \mathrm{E}+06$ & $8.09 E+08$ \\
\hline PB06-1 & $1.26 \mathrm{E}-07$ & $1.43 \mathrm{E}-03$ & $6.77 \mathrm{E}+02$ & $1.79 E+06$ & $1.32 \mathrm{E}+09$ \\
\hline PB06-3 & $2.43 \mathrm{E}-08$ & $1.72 \mathrm{E}-03$ & $6.96 \mathrm{E}+02$ & $1.84 \mathrm{E}+06$ & $1.31 E+09$ \\
\hline PB07-1 & $3.24 \mathrm{E}-07$ & $1.78 \mathrm{E}-04$ & $7.86 \mathrm{E}+02$ & $2.01 E+06$ & $1.74 \mathrm{E}+09$ \\
\hline PB07-3 & $1.46 \mathrm{E}-07$ & $5.20 \mathrm{E}-04$ & $5.78 \mathrm{E}+02$ & $1.47 \mathrm{E}+06$ & $1.17 \mathrm{E}+09$ \\
\hline PB08-1 & $7.54 \mathrm{E}-08$ & $3.18 \mathrm{E}-06$ & $7.89 \mathrm{E}+02$ & $1.94 \mathrm{E}+06$ & $1.91 \mathrm{E}+09$ \\
\hline PB09-1 & $7.60 \mathrm{E}-08$ & $1.63 \mathrm{E}-02$ & $1.51 \mathrm{E}+03$ & $3.95 \mathrm{E}+06$ & $4.73 E+09$ \\
\hline PB09-3 & $1.60 \mathrm{E}-08$ & $4.73 \mathrm{E}-02$ & $1.20 \mathrm{E}+03$ & $3.48 \mathrm{E}+06$ & $3.62 \mathrm{E}+09$ \\
\hline PB10-1 & $1.70 \mathrm{E}-07$ & $1.61 \mathrm{E}-03$ & $1.36 \mathrm{E}+03$ & $3.42 \mathrm{E}+06$ & $4.67 \mathrm{E}+09$ \\
\hline PB11-1 & $1.95 \mathrm{E}-07$ & $9.11 \mathrm{E}-05$ & $1.07 \mathrm{E}+03$ & $2.61 \mathrm{E}+06$ & $3.62 \mathrm{E}+09$ \\
\hline PB12-1 & 5.63E-08 & $6.71 \mathrm{E}-02$ & $3.73 E+03$ & $8.52 \mathrm{E}+06$ & $1.43 E+10$ \\
\hline PB13-1 & $2.45 \mathrm{E}-07$ & $2.71 \mathrm{E}-02$ & $2.68 \mathrm{E}+03$ & $6.41 \mathrm{E}+06$ & $9.93 E+09$ \\
\hline PB13-3 & $1.48 \mathrm{E}-08$ & $1.32 \mathrm{E}-02$ & $2.16 \mathrm{E}+03$ & $5.33 E+06$ & $8.69 E+09$ \\
\hline PB14-1 & $6.04 \mathrm{E}-07$ & $2.11 \mathrm{E}-03$ & $1.54 \mathrm{E}+03$ & $3.79 \mathrm{E}+06$ & $6.76 \mathrm{E}+09$ \\
\hline PB16-1 & $4.31 \mathrm{E}-08$ & $2.13 \mathrm{E}-01$ & $5.46 \mathrm{E}+03$ & $1.14 \mathrm{E}+07$ & $1.81 E+10$ \\
\hline PB17-1 & $3.70 \mathrm{E}-07$ & $0.00 \mathrm{E}+00$ & $1.65 \mathrm{E}-02$ & $6.77 \mathrm{E}+01$ & $2.23 E+02$ \\
\hline PB18-1 & $6.90 \mathrm{E}-07$ & $0.00 \mathrm{E}+00$ & $1.00 \mathrm{E}+00$ & $4.66 \mathrm{E}+03$ & $2.71 \mathrm{E}+05$ \\
\hline PB19-1 & $3.26 \mathrm{E}-07$ & $0.00 \mathrm{E}+00$ & $2.33 \mathrm{E}+02$ & $5.61 \mathrm{E}+05$ & $1.48 \mathrm{E}+08$ \\
\hline PB19-3 & $2.45 \mathrm{E}-08$ & $0.00 \mathrm{E}+00$ & $7.92 \mathrm{E}+01$ & $1.92 \mathrm{E}+05$ & $2.22 \mathrm{E}+07$ \\
\hline
\end{tabular}


Table 4-7 Peach Bottom Consequences to 100 Miles

\begin{tabular}{|c|c|c|c|c|c|}
\hline $\begin{array}{l}\text { Source } \\
\text { Term }\end{array}$ & $\begin{array}{c}\text { Mean } \\
\text { Frequency } \\
(/ \mathbf{y r})\end{array}$ & $\begin{array}{c}\text { Early } \\
\text { Fatalities }\end{array}$ & $\begin{array}{c}\text { Latent } \\
\text { Fatalities }\end{array}$ & $\begin{array}{c}\text { Population } \\
\text { Dose } \\
\text { (Per-rem) }\end{array}$ & $\begin{array}{l}\text { Offsite } \\
\text { Costs } \\
(\$)\end{array}$ \\
\hline PB01-1 & $9.93 \mathrm{E}-08$ & $0.00 \mathrm{E}+00$ & $1.22 \mathrm{E}+02$ & $3.18 \mathrm{E}+05$ & $2.47 \mathrm{E}+07$ \\
\hline PB01-3 & 7.07E-08 & $3.05 \mathrm{E}-06$ & $8.65 \mathrm{E}+01$ & $2.26 \mathrm{E}+05$ & $2.21 \mathrm{E}+07$ \\
\hline PB02-1 & 5.37E-08 & $1.26 \mathrm{E}-03$ & $4.39 \mathrm{E}+02$ & $1.36 \mathrm{E}+06$ & $2.49 \mathrm{E}+08$ \\
\hline PB02-3 & $5.63 \mathrm{E}-08$ & $2.09 \mathrm{E}-03$ & $5.04 \mathrm{E}+02$ & $1.41 \mathrm{E}+06$ & $2.68 \mathrm{E}+08$ \\
\hline PB03-1 & $1.17 \mathrm{E}-07$ & $1.77 \mathrm{E}-05$ & $4.24 \mathrm{E}+02$ & $1.13 E+06$ & $2.49 \mathrm{E}+08$ \\
\hline PB03-3 & $1.13 \mathrm{E}-07$ & $2.43 \mathrm{E}-05$ & $3.33 \mathrm{E}+02$ & $8.61 \mathrm{E}+05$ & $1.34 E+08$ \\
\hline PB04-1 & $9.95 \mathrm{E}-08$ & $1.16 \mathrm{E}-07$ & $5.59 \mathrm{E}+02$ & $1.38 \mathrm{E}+06$ & $2.85 \mathrm{E}+08$ \\
\hline PB04-3 & $2.05 \mathrm{E}-08$ & 7.52E-07 & $4.81 \mathrm{E}+02$ & $1.16 \mathrm{E}+06$ & $3.10 E+08$ \\
\hline PB05-1 & 8.62E-08 & $2.41 \mathrm{E}-02$ & $1.39 \mathrm{E}+03$ & $4.31 \mathrm{E}+06$ & $1.46 \mathrm{E}+09$ \\
\hline PB05-3 & $3.38 \mathrm{E}-08$ & $2.18 \mathrm{E}-02$ & $1.09 \mathrm{E}+03$ & $3.26 \mathrm{E}+06$ & $8.65 \mathrm{E}+08$ \\
\hline PB06-1 & $1.26 \mathrm{E}-07$ & $1.43 \mathrm{E}-03$ & $1.25 \mathrm{E}+03$ & $3.26 \mathrm{E}+06$ & $1.55 E+09$ \\
\hline PB06-3 & $2.43 \mathrm{E}-08$ & $1.72 \mathrm{E}-03$ & $1.22 \mathrm{E}+03$ & $3.20 \mathrm{E}+06$ & $1.74 E+09$ \\
\hline PB07-1 & $3.24 \mathrm{E}-07$ & $1.78 \mathrm{E}-04$ & $1.53 E+03$ & $3.84 \mathrm{E}+06$ & $2.13 E+09$ \\
\hline PB07-3 & $1.46 \mathrm{E}-07$ & $5.20 \mathrm{E}-04$ & $1.02 \mathrm{E}+03$ & $2.60 \mathrm{E}+06$ & $1.54 \mathrm{E}+09$ \\
\hline PB08-1 & $7.54 \mathrm{E}-08$ & $3.18 \mathrm{E}-06$ & $1.59 \mathrm{E}+03$ & $3.87 \mathrm{E}+06$ & $2.41 \mathrm{E}+09$ \\
\hline PB09-1 & $7.60 \mathrm{E}-08$ & $1.63 \mathrm{E}-02$ & $3.02 E+03$ & $7.90 \mathrm{E}+06$ & $7.85 \mathrm{E}+09$ \\
\hline PB09-3 & $1.60 \mathrm{E}-08$ & 4.73E-02 & $2.42 E+03$ & $6.78 \mathrm{E}+06$ & $5.83 E+09$ \\
\hline PB10-1 & $1.70 \mathrm{E}-07$ & $1.61 \mathrm{E}-03$ & $2.92 \mathrm{E}+03$ & $7.33 E+06$ & $7.69 \mathrm{E}+09$ \\
\hline PB11-1 & $1.95 \mathrm{E}-07$ & $9.11 \mathrm{E}-05$ & $2.40 \mathrm{E}+03$ & $5.84 \mathrm{E}+06$ & $5.28 \mathrm{E}+09$ \\
\hline PB12-1 & $5.63 \mathrm{E}-08$ & $6.71 \mathrm{E}-02$ & $7.28 \mathrm{E}+03$ & $1.73 E+07$ & $2.67 \mathrm{E}+10$ \\
\hline PB13-1 & $2.45 \mathrm{E}-07$ & $2.71 \mathrm{E}-02$ & $5.32 \mathrm{E}+03$ & $1.29 \mathrm{E}+07$ & $1.95 \mathrm{E}+10$ \\
\hline PB13-3 & $1.48 \mathrm{E}-08$ & $1.32 \mathrm{E}-02$ & $4.64 \mathrm{E}+03$ & $1.15 \mathrm{E}+07$ & $1.82 \mathrm{E}+10$ \\
\hline PB14-1 & $6.04 \mathrm{E}-07$ & $2.11 \mathrm{E}-03$ & $3.41 \mathrm{E}+03$ & $8.30 \mathrm{E}+06$ & $1.28 \mathrm{E}+10$ \\
\hline PB16-1 & 4.31E-08 & $2.13 \mathrm{E}-01$ & $9.91 \mathrm{E}+03$ & $2.24 \mathrm{E}+07$ & $3.38 \mathrm{E}+10$ \\
\hline PB17-1 & $3.70 \mathrm{E}-07$ & $0.00 \mathrm{E}+00$ & $2.23 \mathrm{E}-02$ & $8.69 \mathrm{E}+01$ & $2.23 E+02$ \\
\hline PB18-1 & $6.90 \mathrm{E}-07$ & $0.00 \mathrm{E}+00$ & $1.35 \mathrm{E}+00$ & $6.19 E+03$ & $2.71 \mathrm{E}+05$ \\
\hline PB19-1 & $3.26 \mathrm{E}-07$ & $0.00 \mathrm{E}+00$ & $3.75 \mathrm{E}+02$ & $8.98 E+05$ & $1.52 \mathrm{E}+08$ \\
\hline PB19-3 & $2.45 \mathrm{E}-08$ & $0.00 \mathrm{E}+00$ & $1.15 \mathrm{E}+02$ & $2.82 E+05$ & $2.23 \mathrm{E}+07$ \\
\hline
\end{tabular}


4 Offsite and Onsite Damage Costs

Table 4-8 Peach Bottom Consequences to 1000 Miles

\begin{tabular}{|c|c|c|c|c|c|}
\hline $\begin{array}{l}\text { Source } \\
\text { Term }\end{array}$ & $\begin{array}{c}\text { Mean } \\
\text { Frequency } \\
(/ y r)\end{array}$ & $\begin{array}{c}\text { Early } \\
\text { Fatalities }\end{array}$ & $\begin{array}{c}\text { Latent } \\
\text { Fatalities }\end{array}$ & $\begin{array}{l}\text { Population } \\
\text { Dose } \\
\text { (Per-rem) }\end{array}$ & $\begin{array}{c}\text { Offsite } \\
\text { Costs } \\
(\$)\end{array}$ \\
\hline PB01-1 & $9.93 E-08$ & $0.00 \mathrm{E}+00$ & $1.68 \mathrm{E}+02$ & $4.43 E+05$ & $2.47 \mathrm{E}+07$ \\
\hline PB01-3 & $7.07 \mathrm{E}-08$ & $3.05 E-06$ & $1.08 \mathrm{E}+02$ & $2.86 \mathrm{E}+05$ & $2.24 \mathrm{E}+07$ \\
\hline PB02-1 & $5.37 \mathrm{E}-08$ & $1.26 \mathrm{E}-03$ & $5.97 \mathrm{E}+02$ & $1.91 \mathrm{E}+06$ & $2.64 \mathrm{E}+08$ \\
\hline $\mathrm{PB} 02-3$ & $5.63 \mathrm{E}-08$ & $2.09 \mathrm{E}-03$ & $6.69 \mathrm{E}+02$ & $1.90 \mathrm{E}+06$ & $2.76 \mathrm{E}+08$ \\
\hline PB03-1 & $1.17 \mathrm{E}-07$ & 1.77E-05 & $6.31 \mathrm{E}+02$ & $1.68 \mathrm{E}+06$ & $2.51 \mathrm{E}+08$ \\
\hline PB03-3 & $1.13 \mathrm{E}-07$ & $2.43 \mathrm{E}-0.5$ & $4.46 \mathrm{E}+02$ & $1.16 \mathrm{E}+06$ & $1.35 \mathrm{E}+08$ \\
\hline PB04-1 & $9.95 \mathrm{E}-08$ & $1.16 \mathrm{E}-07$ & $8.30 \mathrm{E}+02$ & $2.02 E+06$ & $2.87 \mathrm{E}+08$ \\
\hline PB04-3 & $2.05 \mathrm{E}-08$ & 7.52E-07 & $6.64 \mathrm{E}+02$ & $1.58 \mathrm{E}+06$ & $3.11 \mathrm{E}+08$ \\
\hline PB05-1 & $8.62 \mathrm{E}-08$ & $2.41 \mathrm{E}-02$ & $1.96 \mathrm{E}+03$ & $6.04 \mathrm{E}+06$ & $1.55 \mathrm{E}+09$ \\
\hline PB05-3 & $3.38 \mathrm{E}-08$ & $2.18 \mathrm{E}-02$ & $1.46 \mathrm{E}+03$ & $4.36 \mathrm{E}+06$ & $8.92 E+08$ \\
\hline PB06-1 & $1.26 \mathrm{E}-07$ & $1.43 \mathrm{E}-03$ & $1.97 \mathrm{E}+03$ & $5.02 \mathrm{E}+06$ & $1.60 \mathrm{E}+09$ \\
\hline PB06-3 & $2.43 E-08$ & $1.72 \mathrm{E}-03$ & $1.83 E+03$ & $4.70 \mathrm{E}+06$ & $1.79 E+09$ \\
\hline PB07-1 & $3.24 \mathrm{E}-07$ & $1.78 \mathrm{E}-04$ & $2.45 \mathrm{E}+03$ & $6.00 \mathrm{E}+06$ & $2.16 \mathrm{E}+09$ \\
\hline PB07-3 & $1.46 \mathrm{E}-07$ & $5.20 \mathrm{E}-04$ & $1.57 \mathrm{E}+03$ & $3.90 \mathrm{E}+06$ & $1.59 \mathrm{E}+09$ \\
\hline PB08-1 & 7.54E-08 & $3.18 \mathrm{E}-06$ & $2.67 \mathrm{E}+03$ & $6.34 \mathrm{E}+06$ & $2.44 \mathrm{E}+09$ \\
\hline PB09-1 & $7.60 \mathrm{E}-08$ & $1.63 \mathrm{E}-02$ & $5.34 \mathrm{E}+03$ & $1.37 \mathrm{E}+07$ & $9.22 \mathrm{E}+09$ \\
\hline PB09-3 & $1.60 \mathrm{E}-08$ & $4.73 \mathrm{E}-02$ & $3.96 \mathrm{E}+03$ & $1.08 \mathrm{E}+07$ & $6.50 \mathrm{E}+09$ \\
\hline PB10-1 & $1.70 \mathrm{E}-07$ & $1.61 \mathrm{E}-03$ & $5.47 \mathrm{E}+03$ & $1.33 \mathrm{E}+07$ & $8.56 \mathrm{E}+09$ \\
\hline PB11-1 & $1.95 \mathrm{E}-07$ & $9.11 \mathrm{E}-05$ & $4.23 E+03$ & $1.01 \mathrm{E}+07$ & $5.47 \mathrm{E}+09$ \\
\hline PB12-1 & $5.63 \mathrm{E}-08$ & $6.71 \mathrm{E}-02$ & $1.49 \mathrm{E}+04$ & $3.56 \mathrm{E}+07$ & $3.99 \mathrm{E}+10$ \\
\hline PB13-1 & $2.45 \mathrm{E}-07$ & $2.71 \mathrm{E}-02$ & $1.15 \mathrm{E}+04$ & $2.76 \mathrm{E}+07$ & $2.55 E+10$ \\
\hline PB13-3 & $1.48 \mathrm{E}-08$ & $1.32 \mathrm{E}-02$ & $1.07 \mathrm{E}+04$ & $2.61 \mathrm{E}+07$ & $2.53 E+10$ \\
\hline PB14-1 & $6.04 \mathrm{E}-07$ & $2.11 \mathrm{E}-03$ & $7.33 \mathrm{E}+03$ & $1.74 \mathrm{E}+07$ & $1.46 \mathrm{E}+10$ \\
\hline PB16-1 & 4.31E-08 & $2.13 \mathrm{E}-01$ & $1.90 \mathrm{E}+04$ & $4.44 \mathrm{E}+07$ & $5.45 \mathrm{E}+10$ \\
\hline PB17-1 & $3.70 \mathrm{E}-07$ & $0.00 \mathrm{E}+00$ & $3.03 \mathrm{E}-02$ & $1.13 E+02$ & $2.23 \mathrm{E}+02$ \\
\hline PB18-1 & $6.90 \mathrm{E}-07$ & $0.00 \mathrm{E}+00$ & $1.70 \mathrm{E}+00$ & $7.71 \mathrm{E}+03$ & $2.71 \mathrm{E}+05$ \\
\hline PB19-1 & $3.26 \mathrm{E}-07$ & $0.00 \mathrm{E}+00$ & $5.26 \mathrm{E}+02$ & $1.24 \mathrm{E}+06$ & $1.52 E+08$ \\
\hline PB19-3 & $2.45 \mathrm{E}-08$ & $0.00 \mathrm{E}+00$ & $1.45 \mathrm{E}+02$ & $3.54 \mathrm{E}+05$ & $2.23 \mathrm{E}+07$ \\
\hline
\end{tabular}


4 Offsite and Onsite Damage Costs

Table 4-9 Sequoyah Consequences to 10 Miles

\begin{tabular}{|c|c|c|c|c|c|}
\hline Source Term & $\begin{array}{c}\text { Mean } \\
\text { Frequency } \\
(/ \mathrm{yr})\end{array}$ & $\begin{array}{c}\text { Early } \\
\text { Fatalities }\end{array}$ & $\begin{array}{c}\text { Latent } \\
\text { Fatalities }\end{array}$ & $\begin{array}{c}\text { Population } \\
\text { Dose } \\
\text { (Per-rem) }\end{array}$ & $\begin{array}{c}\text { Offsite } \\
\text { Costs } \\
(\$)\end{array}$ \\
\hline SEQ01-2 & $7.80 \mathrm{E}-08$ & $5.80 \mathrm{E}-03$ & $6.92 \mathrm{E}+00$ & $1.38 \mathrm{E}+04$ & $6.93 E+05$ \\
\hline SEQ02-1 & 2.17E-07 & $1.99 \mathrm{E}-04$ & $2.92 E+00$ & $9.67 \mathrm{E}+03$ & $1.21 \mathrm{E}+07$ \\
\hline SEQ02-2 & $1.26 \mathrm{E}-07$ & $6.59 \mathrm{E}-03$ & $1.23 \mathrm{E}+01$ & $2.71 \mathrm{E}+04$ & $1.19 \mathrm{E}+07$ \\
\hline SEQ03-1 & $2.29 \mathrm{E}-07$ & $2.51 \mathrm{E}-04$ & $6.25 \mathrm{E}+00$ & $1.47 \mathrm{E}+04$ & $3.45 \mathrm{E}+07$ \\
\hline SEQ03-2 & $3.31 \mathrm{E}-07$ & $9.00 \mathrm{E}-04$ & $1.85 \mathrm{E}+01$ & $4.35 E+04$ & $5.68 \mathrm{E}+07$ \\
\hline SEQ04-3 & $1.30 \mathrm{E}-07$ & $1.16 \mathrm{E}+00$ & $4.19 \mathrm{E}+01$ & $7.83 E+04$ & $8.75 E+07$ \\
\hline SEQ05-1 & $9.51 \mathrm{E}-08$ & $1.69 \mathrm{E}-03$ & $1.69 \mathrm{E}+01$ & $3.76 \mathrm{E}+04$ & $9.19 E+07$ \\
\hline SEQ05-2 & $1.95 \mathrm{E}-07$ & $7.11 \mathrm{E}-03$ & $7.48 \mathrm{E}+01$ & $1.28 \mathrm{E}+05$ & $1.36 \mathrm{E}+08$ \\
\hline SEQ06-1 & $3.56 \mathrm{E}-07$ & $2.51 \mathrm{E}-04$ & $1.09 \mathrm{E}+01$ & $2.47 \mathrm{E}+04$ & $6.18 \mathrm{E}+07$ \\
\hline SEQ06-2 & $5.54 \mathrm{E}-07$ & $4.88 \mathrm{E}-03$ & $3.13 \mathrm{E}+01$ & $7.71 E+04$ & $1.05 E+08$ \\
\hline SEQ07-3 & $9.70 \mathrm{E}-08$ & $2.51 \mathrm{E}+00$ & $1.17 \mathrm{E}+02$ & $2.41 \mathrm{E}+05$ & $3.20 \mathrm{E}+08$ \\
\hline SEQ08-1 & $1.26 \mathrm{E}-08$ & $1.43 \mathrm{E}-02$ & $1.01 \mathrm{E}+02$ & $1.75 \mathrm{E}+05$ & $2.44 \mathrm{E}+08$ \\
\hline SEQ08-2 & $2.23 \mathrm{E}-07$ & 8.19E-02 & $1.50 \mathrm{E}+02$ & $2.55 \mathrm{E}+05$ & $2.59 \mathrm{E}+08$ \\
\hline SEQ08-3 & $1.25 \mathrm{E}-07$ & $2.12 E+00$ & $9.22 \mathrm{E}+01$ & $1.80 \mathrm{E}+05$ & $2.03 E+08$ \\
\hline SEQ09-1 & $2.40 \mathrm{E}-07$ & 3.75E-03 & $5.32 \mathrm{E}+01$ & $1.15 E+05$ & $2.39 \mathrm{E}+08$ \\
\hline SEQ09-2 & $7.40 \mathrm{E}-07$ & $9.85 \mathrm{E}-02$ & $1.31 E+02$ & $2.23 E+05$ & $1.92 \mathrm{E}+08$ \\
\hline SEQ10-1 & $5.05 \mathrm{E}-08$ & $7.88 \mathrm{E}-04$ & $3.90 \mathrm{E}+01$ & $8.69 E+04$ & $1.75 E+08$ \\
\hline SEQ10-2 & $2.25 \mathrm{E}-08$ & $4.24 \mathrm{E}-06$ & $5.43 \mathrm{E}+01$ & $1.27 \mathrm{E}+05$ & $2.63 E+08$ \\
\hline SEQ11-1 & $1.07 \mathrm{E}-08$ & $1.06 \mathrm{E}-01$ & $2.61 \mathrm{E}+02$ & $4.14 \mathrm{E}+05$ & $3.55 E+08$ \\
\hline SEQ11-2 & $2.91 \mathrm{E}-07$ & $2.47 \mathrm{E}+00$ & $3.17 \mathrm{E}+02$ & $5.97 \mathrm{E}+05$ & $4.26 \mathrm{E}+08$ \\
\hline SEQ11-3 & $2.09 \mathrm{E}-07$ & $2.47 \mathrm{E}+01$ & $7.29 E+02$ & $1.12 E+06$ & $3.04 \mathrm{E}+08$ \\
\hline SEQ12-1 & $3.09 \mathrm{E}-07$ & $3.46 \mathrm{E}-02$ & $1.15 \mathrm{E}+02$ & $2.33 \mathrm{E}+05$ & $3.38 \mathrm{E}+08$ \\
\hline SEQ12-2 & $1.09 \mathrm{E}-06$ & $9.37 \mathrm{E}-01$ & $2.12 E+02$ & $4.06 \mathrm{E}+05$ & $3.48 \mathrm{E}+08$ \\
\hline SEQ13-1 & $1.04 \mathrm{E}-07$ & $1.29 \mathrm{E}-02$ & $8.08 \mathrm{E}+01$ & $1.58 \mathrm{E}+05$ & $2.57 \mathrm{E}+08$ \\
\hline SEQ13-2 & 7.63E-08 & $6.64 \mathrm{E}-02$ & $9.29 \mathrm{E}+01$ & $2.34 \mathrm{E}+05$ & $3.15 E+08$ \\
\hline SEQ14-2 & $4.67 \mathrm{E}-08$ & $4.64 \mathrm{E}+01$ & $1.10 \mathrm{E}+03$ & $2.13 \mathrm{E}+06$ & $4.16 \mathrm{E}+08$ \\
\hline SEQ14-3 & $7.83 \mathrm{E}-08$ & $1.23 \mathrm{E}+02$ & $1.62 \mathrm{E}+03$ & $3.38 \mathrm{E}+06$ & $3.39 \mathrm{E}+08$ \\
\hline SEQ15-1 & $5.86 \mathrm{E}-07$ & $1.21 \mathrm{E}-01$ & $2.51 \mathrm{E}+02$ & $4.85 \mathrm{E}+05$ & $3.24 \mathrm{E}+08$ \\
\hline SEQ15-2 & $3.69 \mathrm{E}-07$ & $1.04 \mathrm{E}+01$ & $3.89 \mathrm{E}+02$ & $9.29 \mathrm{E}+05$ & $3.94 \mathrm{E}+08$ \\
\hline SEQ16-1 & $2.25 \mathrm{E}-05$ & $0.00 \mathrm{E}+00$ & $1.05 \mathrm{E}-02$ & $1.15 \mathrm{E}+02$ & $8.57 \mathrm{E}+02$ \\
\hline SEQ17-1 & $1.50 \mathrm{E}-05$ & $0.00 \mathrm{E}+00$ & $6.47 \mathrm{E}-02$ & $6.04 E+02$ & $2.40 \mathrm{E}+04$ \\
\hline SEQ17-2 & $1.50 \mathrm{E}-08$ & $0.00 \mathrm{E}+00$ & $1.03 \mathrm{E}+00$ & $2.88 \mathrm{E}+03$ & $1.19 \mathrm{E}+05$ \\
\hline SEQ18-1 & $8.88 \mathrm{E}-06$ & $0.00 \mathrm{E}+00$ & $6.16 \mathrm{E}+00$ & $1.61 E+04$ & $7.98 \mathrm{E}+06$ \\
\hline SEQ18-2 & $1.12 \mathrm{E}-06$ & $0.00 \mathrm{E}+00$ & $2.03 E+01$ & $4.66 \mathrm{E}+04$ & $4.30 \mathrm{E}+07$ \\
\hline
\end{tabular}


4 Offsite and Onsite Damage Costs

Table 4-10 Sequoyah Consequences to 50 Miles

\begin{tabular}{|c|c|c|c|c|c|}
\hline Source Term & $\begin{array}{c}\text { Mean } \\
\text { Frequency } \\
(/ \mathbf{y r})\end{array}$ & $\begin{array}{c}\text { Early } \\
\text { Fatalities }\end{array}$ & $\begin{array}{c}\text { Latent } \\
\text { Fatalities }\end{array}$ & $\begin{array}{c}\text { Population } \\
\text { Dose } \\
\text { (Per-rem) }\end{array}$ & $\begin{array}{l}\text { Offsite } \\
\text { Costs } \\
\text { (\$) }\end{array}$ \\
\hline SEQ01-2 & $7.80 \mathrm{E}-08$ & $5.80 \mathrm{E}-03$ & $1.74 \mathrm{E}+01$ & $4.46 \mathrm{E}+04$ & $7.66 \mathrm{E}+05$ \\
\hline SEQ02-1 & 2.17E-07 & $1.99 \mathrm{E}-04$ & $4.51 \mathrm{E}+01$ & $1.64 \mathrm{E}+05$ & $2.23 \mathrm{E}+07$ \\
\hline SEQ02-2 & $1.26 \mathrm{E}-07$ & $6.59 \mathrm{E}-03$ & $6.14 \mathrm{E}+01$ & $1.58 \mathrm{E}+05$ & $1.54 \mathrm{E}+07$ \\
\hline SEQ03-1 & $2.29 \mathrm{E}-07$ & $2.51 \mathrm{E}-04$ & $1.11 E+02$ & $3.19 \mathrm{E}+05$ & $1.44 E+08$ \\
\hline SEQ03-2 & 3.31E-07 & $9.00 \mathrm{E}-04$ & $1.89 \mathrm{E}+02$ & $4.59 E+05$ & $1.79 E+08$ \\
\hline SEQ04-3 & $1.30 \mathrm{E}-07$ & $1.16 \mathrm{E}+00$ & $2.99 \mathrm{E}+02$ & $7.22 \mathrm{E}+05$ & $3.83 E+08$ \\
\hline SEQ05-1 & $9.51 E-08$ & $1.69 \mathrm{E}-03$ & $2.62 \mathrm{E}+02$ & $6.67 E+05$ & $8.71 E+08$ \\
\hline SEQ05-2 & $1.95 \mathrm{E}-07$ & $7.11 \mathrm{E}-03$ & $4.02 E+02$ & $9.33 E+05$ & $1.06 \mathrm{E}+09$ \\
\hline SEQ06-1 & $3.56 \mathrm{E}-07$ & $2.51 \mathrm{E}-04$ & $2.00 \mathrm{E}+02$ & $5.20 \mathrm{E}+05$ & $5.03 E+08$ \\
\hline SEQ06-2 & $5.54 \mathrm{E}-07$ & $4.88 \mathrm{E}-03$ & $3.10 \mathrm{E}+02$ & $7.46 E+05$ & $6.46 \mathrm{E}+08$ \\
\hline SEQ07-3 & $9.70 \mathrm{E}-08$ & $2.51 \mathrm{E}+00$ & $7.10 E+02$ & $1.74 \mathrm{E}+06$ & $2.39 E+09$ \\
\hline SEQ08-1 & $1.26 \mathrm{E}-08$ & $1.43 \mathrm{E}-02$ & $8.25 \mathrm{E}+02$ & $1.81 \mathrm{E}+06$ & $2.20 E+09$ \\
\hline SEQ08-2 & $2.23 \mathrm{E}-07$ & $8.19 \mathrm{E}-02$ & $6.91 E+02$ & $1.60 \mathrm{E}+06$ & $2.33 E+09$ \\
\hline SEQ08-3 & $1.25 \mathrm{E}-07$ & $2.12 \mathrm{E}+00$ & $5.21 \mathrm{E}+02$ & $1.26 \mathrm{E}+06$ & $1.77 \mathrm{E}+09$ \\
\hline SEQ09-1 & $2.40 \mathrm{E}-07$ & $3.75 \mathrm{E}-03$ & $4.86 \mathrm{E}+02$ & $1.21 E+06$ & $1.95 E+09$ \\
\hline SEQ09-2 & $7.40 \mathrm{E}-07$ & $9.85 \mathrm{E}-02$ & $5.47 \mathrm{E}+02$ & $1.24 \mathrm{E}+06$ & $1.59 \mathrm{E}+09$ \\
\hline SEQ10-1 & $5.05 \mathrm{E}-08$ & $7.88 \mathrm{E}-04$ & $3.91 E+02$ & $9.46 \mathrm{E}+05$ & $1.47 \mathrm{E}+09$ \\
\hline SEQ10-2 & $2.25 \mathrm{E}-08$ & $4.24 \mathrm{E}-06$ & $5.78 E+02$ & $1.39 \mathrm{E}+06$ & $1.66 \mathrm{E}+09$ \\
\hline SEQ11-1 & $1.07 \mathrm{E}-08$ & $1.06 \mathrm{E}-01$ & $1.35 E+03$ & $3.04 E+06$ & $4.62 \mathrm{E}+09$ \\
\hline SEQ11-2 & $2.91 \mathrm{E}-07$ & $2.47 \mathrm{E}+00$ & $1.20 \mathrm{E}+03$ & $2.82 \mathrm{E}+06$ & $4.83 E+09$ \\
\hline SEQ11-3 & $2.09 \mathrm{E}-07$ & $2.47 \mathrm{E}+01$ & $1.84 \mathrm{E}+03$ & $3.65 \mathrm{E}+06$ & $3.54 \mathrm{E}+09$ \\
\hline SEQ12-1 & 3.09E-07 & $3.46 \mathrm{E}-02$ & $7.80 \mathrm{E}+02$ & $1.95 E+06$ & $3.67 E+09$ \\
\hline SEQ12-2 & $1.09 \mathrm{E}-06$ & 9.37E-01 & $9.09 \mathrm{E}+02$ & $2.16 \mathrm{E}+06$ & $3.41 \mathrm{E}+09$ \\
\hline SEQ13-1 & $1.04 \mathrm{E}-07$ & $1.29 \mathrm{E}-02$ & $5.56 \mathrm{E}+02$ & $1.36 \mathrm{E}+06$ & $2.32 \mathrm{E}+09$ \\
\hline SEQ13-2 & 7.63E-08 & $6.64 \mathrm{E}-02$ & $6.95 E+02$ & $1.70 \mathrm{E}+06$ & $2.52 \mathrm{E}+09$ \\
\hline SEQ14-2 & 4.67E-08 & $5.14 \mathrm{E}+01$ & $2.59 \mathrm{E}+03$ & $6.01 E+06$ & $7.01 E+09$ \\
\hline SEQ14-3 & 7.83E-08 & $1.24 \mathrm{E}+02$ & $4.30 \mathrm{E}+03$ & $8.68 E+06$ & $5.77 \mathrm{E}+09$ \\
\hline SEQ15-1 & $5.86 \mathrm{E}-07$ & $1.21 \mathrm{E}-01$ & $1.06 \mathrm{E}+03$ & $2.64 E+06$ & $5.20 \mathrm{E}+09$ \\
\hline SEQ15-2 & 3.69E-07 & $1.05 \mathrm{E}+01$ & $1.31 \mathrm{E}+03$ & $3.42 \mathrm{E}+06$ & $5.74 \mathrm{E}+09$ \\
\hline SEQ16-1 & 2.25E-05 & $0.00 \mathrm{E}+00$ & $2.72 \mathrm{E}-02$ & $2.50 \mathrm{E}+02$ & $8.57 \mathrm{E}+02$ \\
\hline SEQ17-1 & $1.50 \mathrm{E}-05$ & $0.00 \mathrm{E}+00$ & $2.95 \mathrm{E}-01$ & $2.42 \mathrm{E}+03$ & $2.40 \mathrm{E}+04$ \\
\hline SEQ17-2 & $1.50 \mathrm{E}-08$ & $0.00 \mathrm{E}+00$ & $3.57 \mathrm{E}+00$ & $1.28 \mathrm{E}+04$ & $1.32 E+05$ \\
\hline SEQ18-1 & $8.88 \mathrm{E}-06$ & $0.00 \mathrm{E}+00$ & $3.81 E+01$ & $1.14 \mathrm{E}+05$ & $1.33 E+07$ \\
\hline SEQ18-2 & 1.12E-06 & $0.00 \mathrm{E}+00$ & $1.68 \mathrm{E}+02$ & $3.96 \mathrm{E}+05$ & $6.93 \mathrm{E}+07$ \\
\hline
\end{tabular}


4 Offsite and Onsite Damage Costs

Table 4-11 Sequoyah Consequences to 100 Miles

\begin{tabular}{|c|c|c|c|c|c|}
\hline Source Term & $\begin{array}{c}\text { Mean } \\
\text { Frequency } \\
(/ y r)\end{array}$ & $\begin{array}{c}\text { Early } \\
\text { Fatalities }\end{array}$ & $\begin{array}{c}\text { Latent } \\
\text { Fatalities }\end{array}$ & $\begin{array}{c}\text { Population } \\
\text { Dose } \\
\text { (Per-rem) }\end{array}$ & $\begin{array}{l}\text { Offsite } \\
\text { Costs } \\
(\$)\end{array}$ \\
\hline SEQ01-2 & $7.80 \mathrm{E}-08$ & $5.80 \mathrm{E}-03$ & $2.06 \mathrm{E}+01$ & $5.63 \mathrm{E}+04$ & $7.66 \mathrm{E}+05$ \\
\hline SEQ02-1 & 2.17E-07 & $1.99 \mathrm{E}-04$ & $5.37 \mathrm{E}+01$ & $2.07 \mathrm{E}+05$ & $2.72 \mathrm{E}+07$ \\
\hline SEQ02-2 & $1.26 \mathrm{E}-07$ & $6.59 \mathrm{E}-03$ & $8.22 E+01$ & $2.24 \mathrm{E}+05$ & $1.55 E+07$ \\
\hline SEQ03-1 & $2.29 \mathrm{E}-07$ & $2.51 \mathrm{E}-04$ & $1.49 \mathrm{E}+02$ & $4.21 \mathrm{E}+05$ & $1.55 \mathrm{E}+08$ \\
\hline SEQ03-2 & $3.31 \mathrm{E}-07$ & $9.00 \mathrm{E}-04$ & $3.06 \mathrm{E}+02$ & $7.30 \mathrm{E}+05$ & $1.80 \mathrm{E}+08$ \\
\hline SEQ04-3 & $1.30 \mathrm{E}-07$ & $1.16 \mathrm{E}+00$ & $4.29 \mathrm{E}+02$ & $1.03 \mathrm{E}+06$ & $3.94 E+08$ \\
\hline SEQ05-1 & $9.51 \mathrm{E}-08$ & $1.69 \mathrm{E}-03$ & $4.32 \mathrm{E}+02$ & $1.07 \mathrm{E}+06$ & $9.06 \mathrm{E}+08$ \\
\hline SEQ05-2 & $1.95 \mathrm{E}-07$ & $7.11 \mathrm{E}-03$ & $6.52 \mathrm{E}+02$ & $1.52 \mathrm{E}+06$ & $1.09 \mathrm{E}+09$ \\
\hline SEQ06-1 & $3.56 \mathrm{E}-07$ & $2.51 \mathrm{E}-04$ & $2.96 \mathrm{E}+02$ & $7.49 E+05$ & $5.22 E+08$ \\
\hline SEQ06-2 & $5.54 \mathrm{E}-07$ & 4.88E-03 & $5.11 E+02$ & $1.20 \mathrm{E}+06$ & $6.61 E+08$ \\
\hline SEQ07-3 & $9.70 \mathrm{E}-08$ & $2.51 E+00$ & $1.23 \mathrm{E}+03$ & $2.98 \mathrm{E}+06$ & $2.86 \mathrm{E}+09$ \\
\hline SEQ08-1 & $1.26 \mathrm{E}-08$ & $1.43 \mathrm{E}-02$ & $1.21 E+03$ & $2.77 \mathrm{E}+06$ & $3.13 E+09$ \\
\hline SEQ08-2 & $2.23 \mathrm{E}-07$ & 8.19E-02 & $1.24 \mathrm{E}+03$ & $2.91 \mathrm{E}+06$ & $2.71 E+09$ \\
\hline SEQ08-3 & $1.25 \mathrm{E}-07$ & $2.12 \mathrm{E}+00$ & $8.44 \mathrm{E}+02$ & $2.04 \mathrm{E}+06$ & $2.11 E+09$ \\
\hline SEQ09-1 & $2.40 \mathrm{E}-07$ & $3.75 \mathrm{E}-03$ & $9.15 \mathrm{E}+02$ & $2.21 \mathrm{E}+06$ & $2.10 \mathrm{E}+09$ \\
\hline SEQ09-2 & $7.40 \mathrm{E}-07$ & $9.85 \mathrm{E}-02$ & $9.47 \mathrm{E}+02$ & $2.18 \mathrm{E}+06$ & $1.72 \mathrm{E}+09$ \\
\hline SEQ10-1 & $5.05 \mathrm{E}-08$ & $7.88 \mathrm{E}-04$ & $6.98 \mathrm{E}+02$ & $1.65 \mathrm{E}+06$ & $1.52 \mathrm{E}+09$ \\
\hline SEQ10-2 & $2.25 \mathrm{E}-08$ & 4.24E-06 & $1.00 \mathrm{E}+03$ & $2.35 \mathrm{E}+06$ & $1.81 \mathrm{E}+09$ \\
\hline SEQ11-1 & $1.07 \mathrm{E}-08$ & $1.06 \mathrm{E}-01$ & $1.93 \mathrm{E}+03$ & $4.45 \mathrm{E}+06$ & $6.90 \mathrm{E}+09$ \\
\hline SEQ11-2 & $2.91 \mathrm{E}-07$ & $2.47 \mathrm{E}+00$ & $1.98 \mathrm{E}+03$ & $4.72 E+06$ & $7.35 E+09$ \\
\hline SEQ11-3 & $2.09 \mathrm{E}-07$ & $2.47 \mathrm{E}+01$ & $2.35 \mathrm{E}+03$ & $4.89 \mathrm{E}+06$ & $5.50 \mathrm{E}+09$ \\
\hline SEQ12-1 & $3.09 \mathrm{E}-07$ & $3.46 \mathrm{E}-02$ & $1.33 E+03$ & $3.26 \mathrm{E}+06$ & $5.06 \mathrm{E}+09$ \\
\hline SEQ12-2 & $1.09 \mathrm{E}-06$ & 9.37E-01 & $1.61 E+03$ & $3.82 \mathrm{E}+06$ & $4.77 \mathrm{E}+09$ \\
\hline SEQ13-1 & $1.04 \mathrm{E}-07$ & $1.29 \mathrm{E}-02$ & $9.49 E+02$ & $2.30 \mathrm{E}+06$ & $3.12 E+09$ \\
\hline SEQ13-2 & $7.63 \mathrm{E}-08$ & $6.64 \mathrm{E}-02$ & $1.35 \mathrm{E}+03$ & $3.18 \mathrm{E}+06$ & $3.05 E+09$ \\
\hline SEQ14-2 & 4.67E-08 & $5.14 \mathrm{E}+01$ & $3.49 \mathrm{E}+03$ & $8.28 \mathrm{E}+06$ & $1.16 \mathrm{E}+10$ \\
\hline SEQ14-3 & $7.83 \mathrm{E}-08$ & $1.24 \mathrm{E}+02$ & $5.08 \mathrm{E}+03$ & $1.06 \mathrm{E}+07$ & $8.99 E+09$ \\
\hline SEQ15-1 & $5.86 \mathrm{E}-07$ & $1.21 \mathrm{E}-01$ & $1.58 \mathrm{E}+03$ & $3.90 \mathrm{E}+06$ & $7.69 \mathrm{E}+09$ \\
\hline SEQ15-2 & $3.69 \mathrm{E}-07$ & $1.05 \mathrm{E}+01$ & $2.14 \mathrm{E}+03$ & $5.45 \mathrm{E}+06$ & $8.87 \mathrm{E}+09$ \\
\hline SEQ16-1 & $2.25 \mathrm{E}-05$ & $0.00 \mathrm{E}+00$ & $3.13 \mathrm{E}-02$ & $2.88 \mathrm{E}+02$ & $8.57 \mathrm{E}+02$ \\
\hline SEQ17-1 & $1.50 \mathrm{E}-05$ & $0.00 E+00$ & $3.60 \mathrm{E}-01$ & $3.04 \mathrm{E}+03$ & $2.40 \mathrm{E}+04$ \\
\hline SEQ17-2 & $1.50 \mathrm{E}-08$ & $0.00 \mathrm{E}+00$ & $4.07 \mathrm{E}+00$ & $1.60 \mathrm{E}+04$ & $1.32 \mathrm{E}+05$ \\
\hline SEQ18-1 & $8.88 \mathrm{E}-06$ & $0.00 \mathrm{E}+00$ & $5.10 \mathrm{E}+01$ & $1.62 \mathrm{E}+05$ & $1.65 \mathrm{E}+07$ \\
\hline SEQ18-2 & $1.12 \mathrm{E}-06$ & $0.00 \mathrm{E}+00$ & $2.43 E+02$ & $5.70 \mathrm{E}+05$ & $6.94 \mathrm{E}+07$ \\
\hline
\end{tabular}


Table 4-12 Sequoyah Consequences to 1000 Miles

\begin{tabular}{|c|c|c|c|c|c|}
\hline Source Term & $\begin{array}{c}\text { Mean } \\
\text { Frequency } \\
(/ y r)\end{array}$ & $\begin{array}{c}\text { Early } \\
\text { Fatalities }\end{array}$ & $\begin{array}{c}\text { Latent } \\
\text { Fatalities }\end{array}$ & $\begin{array}{c}\text { Population } \\
\text { Dose } \\
\text { (Per-rem) }\end{array}$ & $\begin{array}{c}\text { Offsite } \\
\text { Costs } \\
(\$)\end{array}$ \\
\hline SEQ01-2 & $7.80 \mathrm{E}-08$ & $5.80 \mathrm{E}-03$ & $3.07 \mathrm{E}+01$ & $8.95 E+04$ & $7.66 \mathrm{E}+05$ \\
\hline SEQ02-1 & 2.17E-07 & $1.99 \mathrm{E}-04$ & $1.20 \mathrm{E}+02$ & $7.48 \mathrm{E}+05$ & $2.82 \mathrm{E}+07$ \\
\hline SEQ02-2 & $1.26 \mathrm{E}-07$ & $6.59 \mathrm{E}-03$ & $1.53 \mathrm{E}+02$ & $4.43 E+05$ & $1.55 \mathrm{E}+07$ \\
\hline SEQ03-1 & $2.29 \mathrm{E}-07$ & $2.51 \mathrm{E}-04$ & $4.54 \mathrm{E}+02$ & $1.53 E+06$ & $1.57 \mathrm{E}+08$ \\
\hline SEQ03-2 & 3.31E-07 & $9.00 \mathrm{E}-04$ & $7.84 E+02$ & $1.85 \mathrm{E}+06$ & $1.80 E+08$ \\
\hline SEQ04-3 & $1.30 \mathrm{E}-07$ & $1.16 \mathrm{E}+00$ & $1.06 \mathrm{E}+03$ & $2.60 \mathrm{E}+06$ & $3.95 E+08$ \\
\hline SEQ05-1 & $9.51 \mathrm{E}-08$ & $1.69 \mathrm{E}-03$ & $2.40 \mathrm{E}+03$ & $5.61 \mathrm{E}+06$ & $9.51 \mathrm{E}+08$ \\
\hline SEQ05-2 & $1.95 \mathrm{E}-07$ & $7.11 \mathrm{E}-03$ & $2.48 \mathrm{E}+03$ & $5.67 \mathrm{E}+06$ & $1.12 \mathrm{E}+09$ \\
\hline SEQ06-1 & $3.56 \mathrm{E}-07$ & $2.51 \mathrm{E}-04$ & $1.25 \mathrm{E}+03$ & $3.15 E+06$ & $5.48 \mathrm{E}+08$ \\
\hline SEQ06-2 & $5.54 \mathrm{E}-07$ & $4.88 \mathrm{E}-03$ & $1.85 \mathrm{E}+03$ & $4.15 E+06$ & $6.71 E+08$ \\
\hline SEQ07-3 & $9.70 \mathrm{E}-08$ & $2.51 E+00$ & $6.37 \mathrm{E}+03$ & $1.44 E+07$ & $3.11 \mathrm{E}+09$ \\
\hline SEQ08-1 & $1.26 \mathrm{E}-08$ & $1.43 \mathrm{E}-02$ & $6.29 E+03$ & $1.45 \mathrm{E}+07$ & $6.27 E+09$ \\
\hline SEQ08-2 & $2.23 \mathrm{E}-07$ & 8.19E-02 & $6.77 \mathrm{E}+03$ & $1.52 \mathrm{E}+07$ & $2.96 \mathrm{E}+09$ \\
\hline SEQ08-3 & $1.25 \mathrm{E}-07$ & $2.12 \mathrm{E}+00$ & $4.21 \mathrm{E}+03$ & $9.64 E+06$ & $2.35 \mathrm{E}+09$ \\
\hline SEQ09-1 & $2.40 \mathrm{E}-07$ & $3.75 \mathrm{E}-03$ & $4.95 \mathrm{E}+03$ & $1.11 E+07$ & $2.23 E+09$ \\
\hline SEQ09-2 & $7.40 \mathrm{E}-07$ & $9.85 \mathrm{E}-02$ & $5.04 \mathrm{E}+03$ & $1.12 \mathrm{E}+07$ & $1.84 \mathrm{E}+09$ \\
\hline SEQ10-1 & $5.05 \mathrm{E}-08$ & $7.88 \mathrm{E}-04$ & $3.63 \mathrm{E}+03$ & $8.05 E+06$ & $1.56 \mathrm{E}+09$ \\
\hline SEQ10-2 & $2.25 \mathrm{E}-08$ & $4.24 \mathrm{E}-06$ & $4.39 \mathrm{E}+03$ & $9.82 E+06$ & $1.89 \mathrm{E}+09$ \\
\hline SEQ11-1 & $1.07 \mathrm{E}-08$ & $1.06 \mathrm{E}-01$ & $1.35 E+04$ & $3.08 \mathrm{E}+07$ & $1.31 \mathrm{E}+10$ \\
\hline SEQ11-2 & 2.91E-07 & $2.47 \mathrm{E}+00$ & $1.43 E+04$ & $3.25 \mathrm{E}+07$ & $1.17 \mathrm{E}+10$ \\
\hline SEQ11-3 & $2.09 \mathrm{E}-07$ & $2.47 \mathrm{E}+01$ & $1.14 \mathrm{E}+04$ & $2.56 \mathrm{E}+07$ & $9.29 \mathrm{E}+09$ \\
\hline SEQ12-1 & $3.09 \mathrm{E}-07$ & $3.46 \mathrm{E}-02$ & $9.21 E+03$ & $2.08 \mathrm{E}+07$ & $6.56 \mathrm{E}+09$ \\
\hline SEQ12-2 & $1.09 \mathrm{E}-06$ & $9.37 \mathrm{E}-01$ & $1.03 E+04$ & $2.31 \mathrm{E}+07$ & $6.25 E+09$ \\
\hline SEQ13-1 & $1.04 \mathrm{E}-07$ & $1.29 \mathrm{E}-02$ & $6.07 \mathrm{E}+03$ & 1.37E +07 & $3.62 \mathrm{E}+09$ \\
\hline SEQ13-2 & $7.63 E-08$ & $6.64 \mathrm{E}-02$ & $7.86 \mathrm{E}+03$ & $1.73 E+07$ & $3.41 E+09$ \\
\hline SEQ14-2 & 4.67E-08 & $5.14 \mathrm{E}+01$ & $2.29 \mathrm{E}+04$ & $5.32 \mathrm{E}+07$ & $3.71 E+10$ \\
\hline SEQ14-3 & $7.83 \mathrm{E}-08$ & $1.24 E+02$ & $2.01 E+04$ & $4.54 \mathrm{E}+07$ & $2.89 \mathrm{E}+10$ \\
\hline SEQ15-1 & 5.86E-07 & $1.21 \mathrm{E}-01$ & $1.40 \mathrm{E}+04$ & $3.18 \mathrm{E}+07$ & $1.47 \mathrm{E}+10$ \\
\hline SEQ15-2 & 3.69E-07 & $1.05 \mathrm{E}+01$ & $1.87 \mathrm{E}+04$ & $4.27 \mathrm{E}+07$ & $2.05 E+10$ \\
\hline SEQ16-1 & $2.25 \mathrm{E}-05$ & $0.00 \mathrm{E}+00$ & $4.62 \mathrm{E}-02$ & $3.87 \mathrm{E}+02$ & $8.57 \mathrm{E}+02$ \\
\hline SEQ17-1 & $1.50 \mathrm{E}-05$ & $0.00 \mathrm{E}+00$ & $5.43 \mathrm{E}-01$ & $4.41 E+03$ & $2.40 \mathrm{E}+04$ \\
\hline SEQ17-2 & $1.50 \mathrm{E}-08$ & $0.00 \mathrm{E}+00$ & $6.22 \mathrm{E}+00$ & $2.61 E+04$ & $1.32 \mathrm{E}+05$ \\
\hline SEQ18-1 & $8.88 \mathrm{E}-06$ & $0.00 \mathrm{E}+00$ & $1.07 \mathrm{E}+02$ & $4.57 \mathrm{E}+05$ & $1.66 \mathrm{E}+07$ \\
\hline SEQ18-2 & $1.12 \mathrm{E}-06$ & $0.00 \mathrm{E}+00$ & $4.86 \mathrm{E}+02$ & $1.13 E+06$ & $6.94 \mathrm{E}+07$ \\
\hline
\end{tabular}


4 Offsite and Onsite Damage Costs

Table 4-13 Surry Consequences to 10 Miles

\begin{tabular}{|c|c|c|c|c|c|}
\hline $\begin{array}{l}\text { Source } \\
\text { Term }\end{array}$ & $\begin{array}{c}\text { Mean } \\
\text { Frequency } \\
\text { (/yr) }\end{array}$ & $\begin{array}{c}\text { Early } \\
\text { Fatalities }\end{array}$ & $\begin{array}{c}\text { Latent } \\
\text { Fatalities }\end{array}$ & $\begin{array}{c}\text { Population } \\
\text { Dose } \\
\text { (Per-rem) }\end{array}$ & $\begin{array}{l}\text { Offsite } \\
\text { Costs } \\
(\$)\end{array}$ \\
\hline SUR01-3 & $1.80 \mathrm{E}-07$ & $6.41 \mathrm{E}-02$ & $2.77 \mathrm{E}+01$ & $4.97 \mathrm{E}+04$ & $1.18 \mathrm{E}+07$ \\
\hline SUR02-2 & $1.54 \mathrm{E}-08$ & $2.21 \mathrm{E}-01$ & $2.41 \mathrm{E}+02$ & $2.99 \mathrm{E}+05$ & $1.93 E+08$ \\
\hline SUR02-3 & 2.65E-07 & $7.73 \mathrm{E}-02$ & $4.79 \mathrm{E}+01$ & $1.00 \mathrm{E}+05$ & $1.60 \mathrm{E}+08$ \\
\hline SUR03-2 & $1.95 \mathrm{E}-08$ & 2.41E-01 & $2.92 E+02$ & $4.29 \mathrm{E}+05$ & $6.63 E+08$ \\
\hline SUR03-3 & $7.30 \mathrm{E}-07$ & $2.29 \mathrm{E}-01$ & $8.55 \mathrm{E}+01$ & $1.97 \mathrm{E}+05$ & $4.36 \mathrm{E}+08$ \\
\hline SUR04-1 & $1.96 \mathrm{E}-07$ & $8.44 \mathrm{E}-04$ & $3.89 \mathrm{E}+01$ & $9.08 \mathrm{E}+04$ & $4.77 \mathrm{E}+08$ \\
\hline SUR04-2 & $8.40 \mathrm{E}-08$ & $1.40 \mathrm{E}-04$ & $7.25 \mathrm{E}+01$ & $1.72 E+05$ & $4.76 E+08$ \\
\hline SUR05-3 & $9.43 \mathrm{E}-08$ & $2.66 \mathrm{E}+00$ & $1.98 \mathrm{E}+02$ & $5.01 \mathrm{E}+05$ & $6.98 \mathrm{E}+08$ \\
\hline SUR06-3 & $6.94 \mathrm{E}-08$ & $1.89 \mathrm{E}+00$ & $1.84 \mathrm{E}+02$ & $4.26 \mathrm{E}+05$ & $6.23 E+08$ \\
\hline SUR07-1 & $3.30 \mathrm{E}-08$ & $5.01 \mathrm{E}-02$ & $6.79 E+01$ & $1.31 \mathrm{E}+05$ & $5.91 E+08$ \\
\hline SUR07-2 & $1.13 \mathrm{E}-07$ & $2.59 \mathrm{E}+00$ & $4.73 \mathrm{E}+02$ & $6.47 \mathrm{E}+05$ & $8.50 \mathrm{E}+08$ \\
\hline SUR07-3 & $1.34 \mathrm{E}-07$ & $7.18 \mathrm{E}-01$ & $1.21 \mathrm{E}+02$ & $2.73 \mathrm{E}+05$ & $5.23 \mathrm{E}+08$ \\
\hline SUR08-1 & $1.37 \mathrm{E}-07$ & $8.94 \mathrm{E}-03$ & $4.81 \mathrm{E}+01$ & $1.08 \mathrm{E}+05$ & $6.09 E+08$ \\
\hline SUR08-2 & $8.29 \mathrm{E}-08$ & $8.32 \mathrm{E}-03$ & $8.22 \mathrm{E}+01$ & $1.93 \mathrm{E}+05$ & $7.28 \mathrm{E}+08$ \\
\hline SUR09-1 & $1.53 \mathrm{E}-07$ & $3.52 \mathrm{E}-03$ & $3.90 \mathrm{E}+01$ & $8.89 \mathrm{E}+04$ & $5.49 \mathrm{E}+08$ \\
\hline SUR09-2 & $7.68 \mathrm{E}-08$ & $2.05 \mathrm{E}-03$ & $7.52 \mathrm{E}+01$ & $1.76 \mathrm{E}+05$ & $6.34 \mathrm{E}+08$ \\
\hline SUR10-3 & 4.54E-08 & $1.52 \mathrm{E}+01$ & $3.12 \mathrm{E}+02$ & $8.28 \mathrm{E}+05$ & $7.22 \mathrm{E}+08$ \\
\hline SUR11-1 & $2.65 \mathrm{E}-08$ & $3.30 \mathrm{E}-01$ & $1.17 \mathrm{E}+02$ & $2.21 \mathrm{E}+05$ & $7.19 \mathrm{E}+08$ \\
\hline SUR11-2 & $2.95 \mathrm{E}-08$ & $1.31 \mathrm{E}-02$ & $1.16 \mathrm{E}+02$ & $2.17 \mathrm{E}+05$ & $5.61 E+08$ \\
\hline SUR11-3 & $1.24 \mathrm{E}-07$ & $5.61 \mathrm{E}+00$ & $2.71 \mathrm{E}+02$ & $6.29 \mathrm{E}+05$ & $6.87 \mathrm{E}+08$ \\
\hline SUR12-1 & 1.01E-07 & $1.37 \mathrm{E}-01$ & $8.01 \mathrm{E}+01$ & $1.66 \mathrm{E}+05$ & $6.99 \mathrm{E}+08$ \\
\hline SUR12-2 & $2.93 \mathrm{E}-08$ & $1.10 \mathrm{E}-01$ & $1.46 \mathrm{E}+02$ & $3.10 \mathrm{E}+05$ & $8.61 E+08$ \\
\hline SUR13-1 & $1.18 \mathrm{E}-07$ & $3.92 \mathrm{E}-02$ & $6.32 \mathrm{E}+01$ & $1.40 \mathrm{E}+05$ & $6.82 \mathrm{E}+08$ \\
\hline SUR14-1 & $1.10 \mathrm{E}-07$ & $1.73 \mathrm{E}-02$ & $5.69 \mathrm{E}+01$ & $1.28 \mathrm{E}+05$ & $6.48 \mathrm{E}+08$ \\
\hline SUR15-1 & $1.50 \mathrm{E}-05$ & $0.00 \mathrm{E}+00$ & $3.46 \mathrm{E}-03$ & $3.39 \mathrm{E}+01$ & $1.51 \mathrm{E}+03$ \\
\hline SUR16-1 & $1.90 \mathrm{E}-05$ & $0.00 \mathrm{E}+00$ & $2.98 \mathrm{E}-02$ & $2.40 \mathrm{E}+02$ & $1.89 \mathrm{E}+04$ \\
\hline SUR17-1 & $3.20 \mathrm{E}-06$ & $0.00 \mathrm{E}+00$ & $1.62 \mathrm{E}+01$ & $3.95 \mathrm{E}+04$ & $7.92 \mathrm{E}+07$ \\
\hline SUR17-2 & $1.97 \mathrm{E}-07$ & $3.87 \mathrm{E}-05$ & $3.76 E+01$ & $9.04 \mathrm{E}+04$ & $1.89 E+08$ \\
\hline
\end{tabular}


4 Offsite and Onsite Damage Costs

Table 4-14 Surry Consequences to 50 Miles

\begin{tabular}{|c|c|c|c|c|c|}
\hline $\begin{array}{c}\text { Source } \\
\text { Term }\end{array}$ & $\begin{array}{c}\text { Mean } \\
\text { Frequency } \\
(/ \mathbf{y r})\end{array}$ & $\begin{array}{c}\text { Early } \\
\text { Fatalities }\end{array}$ & $\begin{array}{c}\text { Latent } \\
\text { Fatalities }\end{array}$ & $\begin{array}{l}\text { Population } \\
\text { Dose } \\
\text { (Per-rem) }\end{array}$ & $\begin{array}{c}\text { Offsite } \\
\text { Costs } \\
(\$)\end{array}$ \\
\hline SUR01-3 & $1.80 \mathrm{E}-07$ & $6.41 \mathrm{E}-02$ & $6.28 \mathrm{E}+01$ & $1.40 \mathrm{E}+05$ & $1.37 \mathrm{E}+07$ \\
\hline SUR02-2 & $1.54 \mathrm{E}-08$ & $2.21 \mathrm{E}-01$ & $6.46 \mathrm{E}+02$ & $1.20 \mathrm{E}+06$ & $1.64 E+09$ \\
\hline SUR02-3 & $2.65 \mathrm{E}-07$ & $7.73 \mathrm{E}-02$ & $2.79 \mathrm{E}+02$ & $6.62 \mathrm{E}+05$ & $4.07 \mathrm{E}+08$ \\
\hline SUR03-2 & $1.95 \mathrm{E}-08$ & $2.41 \mathrm{E}-01$ & $1.19 \mathrm{E}+03$ & $2.56 \mathrm{E}+06$ & $3.60 \mathrm{E}+09$ \\
\hline SUR03-3 & $7.30 \mathrm{E}-07$ & $2.29 \mathrm{E}-01$ & $5.30 \mathrm{E}+02$ & $1.30 \mathrm{E}+06$ & $1.85 \mathrm{E}+09$ \\
\hline SUR04-1 & $1.96 \mathrm{E}-07$ & $8.44 \mathrm{E}-04$ & $4.88 \mathrm{E}+02$ & $1.20 \mathrm{E}+06$ & $2.20 \mathrm{E}+09$ \\
\hline SUR04-2 & $8.40 \mathrm{E}-08$ & $1.40 \mathrm{E}-04$ & $6.70 \mathrm{E}+02$ & $1.62 \mathrm{E}+06$ & $1.93 \mathrm{E}+09$ \\
\hline SUR05-3 & $9.43 \mathrm{E}-08$ & $2.66 \mathrm{E}+00$ & $1.17 \mathrm{E}+03$ & $2.94 \mathrm{E}+06$ & $4.97 \mathrm{E}+09$ \\
\hline SUR06-3 & $6.94 \mathrm{E}-08$ & $1.89 \mathrm{E}+00$ & $9.59 \mathrm{E}+02$ & $2.40 \mathrm{E}+06$ & $4.15 \mathrm{E}+09$ \\
\hline SUR07-1 & $3.30 \mathrm{E}-08$ & $5.01 \mathrm{E}-02$ & $1.50 \mathrm{E}+03$ & $3.02 \mathrm{E}+06$ & $4.12 \mathrm{E}+09$ \\
\hline SUR07-2 & 1.13E-07 & $2.59 \mathrm{E}+00$ & $1.88 \mathrm{E}+03$ & $3.84 \mathrm{E}+06$ & $5.15 E+09$ \\
\hline SUR07-3 & $1.34 \mathrm{E}-07$ & $7.18 \mathrm{E}-01$ & $6.67 \mathrm{E}+02$ & $1.66 \mathrm{E}+06$ & $2.82 \mathrm{E}+09$ \\
\hline SUR08-1 & $1.37 \mathrm{E}-07$ & $8.94 \mathrm{E}-03$ & $7.47 \mathrm{E}+02$ & $1.87 \mathrm{E}+06$ & $3.94 E+09$ \\
\hline SUR08-2 & $8.29 \mathrm{E}-08$ & $8.32 \mathrm{E}-03$ & $9.88 \mathrm{E}+02$ & $2.43 \mathrm{E}+06$ & $4.03 E+09$ \\
\hline SUR09-1 & $1.53 \mathrm{E}-07$ & $3.52 \mathrm{E}-03$ & $6.13 E+02$ & $1.52 \mathrm{E}+06$ & $3.12 \mathrm{E}+09$ \\
\hline SUR09-2 & $7.68 \mathrm{E}-08$ & $2.05 \mathrm{E}-03$ & $7.86 \mathrm{E}+02$ & $1.91 \mathrm{E}+06$ & $2.78 \mathrm{E}+09$ \\
\hline SUR10-3 & 4.54E-08 & $1.54 \mathrm{E}+01$ & $1.38 \mathrm{E}+03$ & $3.61 \mathrm{E}+06$ & $6.18 \mathrm{E}+09$ \\
\hline SUR11-1 & $2.65 \mathrm{E}-08$ & $3.40 \mathrm{E}-01$ & $2.54 \mathrm{E}+03$ & $4.88 \mathrm{E}+06$ & $6.63 E+09$ \\
\hline SUR11-2 & $2.95 \mathrm{E}-08$ & 5.62E-01 & $1.30 \mathrm{E}+03$ & $3.13 E+06$ & $5.97 \mathrm{E}+09$ \\
\hline SUR11-3 & $1.24 \mathrm{E}-07$ & $5.61 \mathrm{E}+00$ & $1.20 \mathrm{E}+03$ & $3.03 E+06$ & $5.11 \mathrm{E}+09$ \\
\hline SUR12-1 & $1.01 \mathrm{E}-07$ & $1.40 \mathrm{E}-01$ & $1.25 \mathrm{E}+03$ & $2.99 \mathrm{E}+06$ & $5.70 \mathrm{E}+09$ \\
\hline SUR12-2 & $2.93 \mathrm{E}-08$ & $1.33 \mathrm{E}-01$ & $1.38 \mathrm{E}+03$ & $3.41 \mathrm{E}+06$ & $6.11 \mathrm{E}+09$ \\
\hline SUR13-1 & $1.18 \mathrm{E}-07$ & $3.92 \mathrm{E}-02$ & $9.51 \mathrm{E}+02$ & $2.40 \mathrm{E}+06$ & $5.14 \mathrm{E}+09$ \\
\hline SỤR14-1 & $1.10 \mathrm{E}-07$ & $1.73 \mathrm{E}-02$ & $8.38 \mathrm{E}+02$ & $2.11 \mathrm{E}+06$ & $4.46 \mathrm{E}+09$ \\
\hline SUR15-1 & $1.50 \mathrm{E}-05$ & $0.00 \mathrm{E}+00$ & $1.08 \mathrm{E}-02$ & $7.67 \mathrm{E}+01$ & $1.51 \mathrm{E}+03$ \\
\hline SUR16-1 & $1.90 \mathrm{E}-05$ & $0.00 \mathrm{E}+00$ & 1.19E-01 & $8.17 \mathrm{E}+02$ & $1.89 \mathrm{E}+04$ \\
\hline SUR17-1 & $3.20 \mathrm{E}-06$ & $0.00 \mathrm{E}+00$ & $1.20 \mathrm{E}+02$ & $3.03 E+05$ & $1.32 \mathrm{E}+08$ \\
\hline SUR17-2 & $1.97 \mathrm{E}-07$ & $3.87 \mathrm{E}-05$ & $3.12 \mathrm{E}+02$ & $7.48 \mathrm{E}+05$ & $5.86 \mathrm{E}+08$ \\
\hline
\end{tabular}


Offsite and Onsite Damage Costs

Table 4-15 Surry Consequences to 100 Miles

\begin{tabular}{|c|c|c|c|c|c|}
\hline $\begin{array}{l}\text { Source } \\
\text { Term }\end{array}$ & $\begin{array}{c}\text { Mean } \\
\text { Frequency } \\
(/ \mathbf{y r})\end{array}$ & $\begin{array}{c}\text { Early } \\
\text { Fatalities }\end{array}$ & $\begin{array}{c}\text { Latent } \\
\text { Fatalities }\end{array}$ & $\begin{array}{c}\text { Population } \\
\text { Dose } \\
\text { (Per-rem) }\end{array}$ & $\begin{array}{c}\text { Offsite } \\
\text { Costs } \\
(\$)\end{array}$ \\
\hline SUR01-3 & $1.80 \mathrm{E}-07$ & $6.41 \mathrm{E}-02$ & $7.07 \mathrm{E}+01$ & $1.66 \mathrm{E}+05$ & $1.38 \mathrm{E}+07$ \\
\hline SUR02-2 & $1.54 \mathrm{E}-08$ & $2.21 \mathrm{E}-01$ & $7.80 \mathrm{E}+02$ & $1.51 \mathrm{E}+06$ & $2.27 \mathrm{E}+09$ \\
\hline SUR02-3 & $2.65 \mathrm{E}-07$ & 7.73E-02 & $3.64 \mathrm{E}+02$ & $8.58 \mathrm{E}+05$ & $4.24 \mathrm{E}+08$ \\
\hline SUR03-2 & $1.95 \mathrm{E}-08$ & $2.41 \mathrm{E}-01$ & $1.56 \mathrm{E}+03$ & $3.44 \mathrm{E}+06$ & $4.71 E+09$ \\
\hline SUR03-3 & $7.30 \mathrm{E}-07$ & $2.29 \mathrm{E}-01$ & $7.36 \mathrm{E}+02$ & $1.79 \mathrm{E}+06$ & $2.05 \mathrm{E}+09$ \\
\hline SUR04-1 & $1.96 \mathrm{E}-07$ & $8.44 \mathrm{E}-04$ & $7.05 \mathrm{E}+02$ & $1.70 \mathrm{E}+06$ & $2.50 \mathrm{E}+09$ \\
\hline SUR04-2 & $8.40 \mathrm{E}-08$ & $1.40 \mathrm{E}-04$ & $9.33 \mathrm{E}+02$ & $2.22 \mathrm{E}+06$ & $2.09 E+09$ \\
\hline SUR05-3 & $9.43 \mathrm{E}-08$ & $2.66 \mathrm{E}+00$ & $1.52 \mathrm{E}+03$ & $3.79 \mathrm{E}+06$ & $6.40 \mathrm{E}+09$ \\
\hline SUR06-3 & $6.94 \mathrm{E}-08$ & $1.89 \mathrm{E}+00$ & $1.27 \mathrm{E}+03$ & $3.15 \mathrm{E}+06$ & $5.31 \mathrm{E}+09$ \\
\hline SUR07-1 & $3.30 \mathrm{E}-08$ & $5.01 \mathrm{E}-02$ & $1.82 \mathrm{E}+03$ & $3.76 \mathrm{E}+06$ & $5.43 \mathrm{E}+09$ \\
\hline SUR07-2 & $1.13 \mathrm{E}-07$ & $2.59 \mathrm{E}+00$ & $2.30 \mathrm{E}+03$ & $4.82 \mathrm{E}+06$ & $6.65 \mathrm{E}+09$ \\
\hline SUR07-3 & $1.34 \mathrm{E}-07$ & $7.18 \mathrm{E}-01$ & $9.26 \mathrm{E}+02$ & $2.27 \mathrm{E}+06$ & $3.34 \mathrm{E}+09$ \\
\hline SUR08-1 & $1.37 \mathrm{E}-07$ & $8.94 \mathrm{E}-03$ & $1.04 \mathrm{E}+03$ & $2.55 \mathrm{E}+06$ & $4.89 \mathrm{E}+09$ \\
\hline SUR08-2 & $8.29 \mathrm{E}-08$ & 8.32E-03 & $1.41 \mathrm{E}+03$ & $3.41 \mathrm{E}+06$ & $4.85 \mathrm{E}+09$ \\
\hline SUR09-1 & $1.53 \mathrm{E}-07$ & $3.52 \mathrm{E}-03$ & $9.06 \mathrm{E}+02$ & $2.21 \mathrm{E}+06$ & $3.73 \mathrm{E}+09$ \\
\hline SUR09-2 & 7.68E-08 & $2.05 \mathrm{E}-03$ & $1.11 \mathrm{E}+03$ & $2.64 \mathrm{E}+06$ & $3.17 \mathrm{E}+09$ \\
\hline SUR10-3 & 4.54E-08 & $1.54 \mathrm{E}+01$ & $1.77 \mathrm{E}+03$ & $4.56 \mathrm{E}+06$ & $7.89 \mathrm{E}+09$ \\
\hline SUR11-1 & $2.65 \mathrm{E}-08$ & $3.40 \mathrm{E}-01$ & $3.00 \mathrm{E}+03$ & $5.93 \mathrm{E}+06$ & $8.56 \mathrm{E}+09$ \\
\hline SUR11-2 & $2.95 \mathrm{E}-08$ & $5.62 \mathrm{E}-01$ & $1.74 \mathrm{E}+03$ & $4.19 \mathrm{E}+06$ & $7.94 \mathrm{E}+09$ \\
\hline SUR11-3 & $1.24 \mathrm{E}-07$ & $5.61 \mathrm{E}+00$ & $1.52 \mathrm{E}+03$ & $3.82 \mathrm{E}+06$ & $6.59 \mathrm{E}+09$ \\
\hline SUR12-1 & $1.01 \mathrm{E}-07$ & $1.40 \mathrm{E}-01$ & $1.61 \mathrm{E}+03$ & $3.84 \mathrm{E}+06$ & $7.17 \mathrm{E}+09$ \\
\hline SUR12-2 & $2.93 \mathrm{E}-08$ & $1.33 \mathrm{E}-01$ & $1.87 \mathrm{E}+03$ & $4.58 \mathrm{E}+06$ & $7.84 \mathrm{E}+09$ \\
\hline SUR13-1 & $1.18 \mathrm{E}-07$ & $3.92 \mathrm{E}-02$ & $1.27 \mathrm{E}+03$ & $3.16 \mathrm{E}+06$ & $6.39 \mathrm{E}+09$ \\
\hline SUR14-1 & $1.10 \mathrm{E}-07$ & $1.73 \mathrm{E}-02$ & $1.15 \mathrm{E}+03$ & $2.84 \mathrm{E}+06$ & $5.55 \mathrm{E}+09$ \\
\hline SUR15-1 & $1.50 \mathrm{E}-05$ & $0.00 \mathrm{E}+00$ & $1.22 \mathrm{E}-02$ & $8.74 \mathrm{E}+01$ & $1.51 \mathrm{E}+03$ \\
\hline SUR16-1 & $1.90 \mathrm{E}-05$ & $0.00 \mathrm{E}+00$ & 1.36E-01 & $9.66 \mathrm{E}+02$ & $1.89 \mathrm{E}+04$ \\
\hline SUR17-1 & $3.20 \mathrm{E}-06$ & $0.00 \mathrm{E}+00$ & $1.58 \mathrm{E}+02$ & $3.99 \mathrm{E}+05$ & $1.34 \mathrm{E}+08$ \\
\hline SUR17-2 & 1.97E-07 & $3.87 \mathrm{E}-05$ & $4.16 \mathrm{E}+02$ & $9.80 \mathrm{E}+05$ & $6.19 \mathrm{E}+08$ \\
\hline
\end{tabular}


4 Offsite and Onsite Damage Costs

Table 4-16 Surry Consequences to 1000 Miles

\begin{tabular}{|c|c|c|c|c|c|}
\hline $\begin{array}{c}\text { Source } \\
\text { Term }\end{array}$ & $\begin{array}{c}\text { Mean } \\
\text { Frequency } \\
(/ \mathbf{y r})\end{array}$ & $\begin{array}{c}\text { Early } \\
\text { Fatalities }\end{array}$ & $\begin{array}{c}\text { Latent } \\
\text { Fatalities }\end{array}$ & $\begin{array}{c}\text { Population } \\
\text { Dose } \\
\text { (Per-rem) }\end{array}$ & $\begin{array}{c}\text { Offsite } \\
\text { Costs } \\
(\$)\end{array}$ \\
\hline SUR01-3 & $1.80 \mathrm{E}-07$ & $6.41 \mathrm{E}-02$ & $1.03 E+02$ & $2.66 \mathrm{E}+05$ & $1.38 \mathrm{E}+07$ \\
\hline SUR02-2 & $1.54 \mathrm{E}-08$ & 2.21E-01 & $2.36 \mathrm{E}+03$ & $5.33 \mathrm{E}+06$ & $3.18 \mathrm{E}+09$ \\
\hline SUR02-3 & $2.65 \mathrm{E}-07$ & 7.73E-02 & $8.04 \mathrm{E}+02$ & $1.88 \mathrm{E}+06$ & $4.30 \mathrm{E}+08$ \\
\hline SUR03-2 & $1.95 \mathrm{E}-08$ & $2.41 \mathrm{E}-01$ & $5.51 \mathrm{E}+03$ & $1.28 \mathrm{E}+07$ & $6.26 \mathrm{E}+09$ \\
\hline SUR03-3 & $7.30 \mathrm{E}-07$ & $2.29 \mathrm{E}-01$ & $2.46 \mathrm{E}+03$ & $5.80 \mathrm{E}+06$ & $2.23 \mathrm{E}+09$ \\
\hline SUR04-1 & $1.96 \mathrm{E}-07$ & 8.44E-04 & $2.98 \mathrm{E}+03$ & $6.93 \mathrm{E}+06$ & $2.84 \mathrm{E}+09$ \\
\hline SUR04-2 & $8.40 \mathrm{E}-08$ & $1.40 \mathrm{E}-04$ & $3.13 \mathrm{E}+03$ & $7.20 \mathrm{E}+06$ & $2.22 \mathrm{E}+09$ \\
\hline SUR05-3 & 9.43E-08 & $2.66 \mathrm{E}+00$ & $7.93 E+03$ & $1.90 \mathrm{E}+07$ & $9.92 \mathrm{E}+09$ \\
\hline SUR06-3 & $6.94 \mathrm{E}-08$ & $1.89 \mathrm{E}+00$ & $6.86 \mathrm{E}+03$ & $1.62 \mathrm{E}+07$ & $7.68 \mathrm{E}+09$ \\
\hline SUR07-1 & 3.30E-08 & $5.01 \mathrm{E}-02$ & $7.72 \mathrm{E}+03$ & $1.78 \mathrm{E}+07$ & $1.19 \mathrm{E}+10$ \\
\hline SUR07-2 & 1.13E-07 & $2.59 \mathrm{E}+00$ & $9.34 E+03$ & $2.14 \mathrm{E}+07$ & $1.10 \mathrm{E}+10$ \\
\hline SUR07-3 & $1.34 \mathrm{E}-07$ & 7.18E-01 & $4.05 \mathrm{E}+03$ & $9.56 \mathrm{E}+06$ & $4.00 \mathrm{E}+09$ \\
\hline SUR08-1 & $1.37 \mathrm{E}-07$ & $8.94 \mathrm{E}-03$ & $6.61 E+03$ & $1.54 \mathrm{E}+07$ & $7.04 \mathrm{E}+09$ \\
\hline SUR08-2 & 8.29E-08 & $8.32 \mathrm{E}-03$ & $7.18 \mathrm{E}+03$ & $1.67 \mathrm{E}+07$ & $6.37 \mathrm{E}+09$ \\
\hline SUR09-1 & $1.53 \mathrm{E}-07$ & $3.52 \mathrm{E}-03$ & $4.76 \mathrm{E}+03$ & $1.11 \mathrm{E}+07$ & $4.55 \mathrm{E}+09$ \\
\hline SUR09-2 & 7.68E-08 & $2.05 \mathrm{E}-03$ & $4.32 \mathrm{E}+03$ & $9.98 \mathrm{E}+06$ & $3.45 \mathrm{E}+09$ \\
\hline SUR10-3 & $4.54 \mathrm{E}-08$ & $1.54 \mathrm{E}+01$ & $1.13 \mathrm{E}+04$ & $2.68 \mathrm{E}+07$ & $1.53 \mathrm{E}+10$ \\
\hline SUR11-1 & $2.65 \mathrm{E}-08$ & $3.40 \mathrm{E}-01$ & $1.35 \mathrm{E}+04$ & $3.06 \mathrm{E}+07$ & $2.48 \mathrm{E}+10$ \\
\hline SUR11-2 & 2.95E-08 & 5.62E-01 & $1.54 \mathrm{E}+04$ & $3.62 \mathrm{E}+07$ & $2.55 \mathrm{E}+10$ \\
\hline SUR11-3 & $1.24 \mathrm{E}-07$ & $5.61 \mathrm{E}+00$ & $8.82 E+03$ & $2.10 \mathrm{E}+07$ & $1.07 \mathrm{E}+10$ \\
\hline SUR12-1 & 1.01E-07 & $1.40 \mathrm{E}-01$ & $1.06 \mathrm{E}+04$ & $2.49 \mathrm{E}+07$ & $1.50 \mathrm{E}+10$ \\
\hline SUR12-2 & $2.93 \mathrm{E}-08$ & $1.33 \mathrm{E}-01$ & $1.25 \mathrm{E}+04$ & $2.93 \mathrm{E}+07$ & $1.62 \mathrm{E}+10$ \\
\hline SUR13-1 & $1.18 \mathrm{E}-07$ & $3.92 \mathrm{E}-02$ & $9.08 \mathrm{E}+03$ & $2.12 \mathrm{E}+07$ & $1.17 \mathrm{E}+10$ \\
\hline SUR14-1 & $1.10 \mathrm{E}-07$ & $1.73 \mathrm{E}-02$ & $7.85 \mathrm{E}+03$ & $1.83 \mathrm{E}+07$ & $8.63 \mathrm{E}+09$ \\
\hline SUR15-1 & $1.50 \mathrm{E}-05$ & $0.00 \mathrm{E}+00$ & $2.28 \mathrm{E}-02$ & $1.32 \mathrm{E}+02$ & $1.51 \mathrm{E}+03$ \\
\hline SUR16-1 & $1.90 \mathrm{E}-05$ & $0.00 \mathrm{E}+00$ & $2.15 \mathrm{E}-01$ & $1.40 \mathrm{E}+03$ & $1.89 \mathrm{E}+04$ \\
\hline SUR17-1 & $3.20 \mathrm{E}-06$ & $0.00 \mathrm{E}+00$ & $3.25 \mathrm{E}+02$ & $8.35 \mathrm{E}+05$ & $1.35 \mathrm{E}+08$ \\
\hline SUR17-2 & $1.97 \mathrm{E}-07$ & $3.87 \mathrm{E}-05$ & $1.05 \mathrm{E}+03$ & $2.42 \mathrm{E}+06$ & $6.28 \mathrm{E}+08$ \\
\hline
\end{tabular}


Table 4-17 Zion Consequences to 10 Miles

\begin{tabular}{|c|c|c|c|c|c|}
\hline $\begin{array}{l}\text { Source } \\
\text { Term }\end{array}$ & $\begin{array}{c}\text { Mean } \\
\text { Frequency } \\
(/ \mathbf{y r})\end{array}$ & $\begin{array}{c}\text { Early } \\
\text { Fatalities }\end{array}$ & $\begin{array}{c}\text { Latent } \\
\text { Fatalities }\end{array}$ & $\begin{array}{c}\text { Population } \\
\text { Dose } \\
\text { (Per-rem) }\end{array}$ & $\begin{array}{l}\text { Ofisite } \\
\text { Costs } \\
(\$)\end{array}$ \\
\hline ZIO-001 & $4.10 \mathrm{E}-08$ & $2.43 \mathrm{E}-01$ & $5.29 \mathrm{E}+01$ & $9.82 \mathrm{E}+04$ & $1.33 \mathrm{E}+07$ \\
\hline ZIO-002 & $2.40 \mathrm{E}-08$ & $0.00 \mathrm{E}+00$ & $3.47 \mathrm{E}+01$ & $8.24 E+04$ & $1.01 \mathrm{E}+08$ \\
\hline ZIO-031 & $7.00 \mathrm{E}-08$ & $7.22 \mathrm{E}-01$ & $7.47 \mathrm{E}+01$ & $1.35 \mathrm{E}+05$ & $2.48 \mathrm{E}+07$ \\
\hline ZIO-061 & $2.30 \mathrm{E}-08$ & 7.17E-01 & $7.13 \mathrm{E}+01$ & $1.28 \mathrm{E}+05$ & $2.14 \mathrm{E}+07$ \\
\hline ZIO-064 & $2.40 \mathrm{E}-07$ & $6.28 \mathrm{E}-01$ & $1.00 \mathrm{E}+02$ & $2.01 \mathrm{E}+05$ & $1.25 \mathrm{E}+08$ \\
\hline ZIO-065 & $7.50 \mathrm{E}-08$ & $3.75 \mathrm{E}-06$ & $6.78 \mathrm{E}+01$ & $1.62 \mathrm{E}+05$ & $2.91 \mathrm{E}+08$ \\
\hline $\mathrm{ZIO}-066$ & $2.00 \mathrm{E}-07$ & $0.00 \mathrm{E}+00$ & $3.60 \mathrm{E}+01$ & $8.57 \mathrm{E}+04$ & $7.70 E+07$ \\
\hline ZIO-067 & $3.70 \mathrm{E}-07$ & $5.61 \mathrm{E}-01$ & $1.54 \mathrm{E}+02$ & $3.28 \mathrm{E}+05$ & 3.57E+08 \\
\hline ZIO-068 & $1.60 \mathrm{E}-07$ & $6.16 \mathrm{E}-04$ & $1.05 \mathrm{E}+02$ & $2.53 \mathrm{E}+05$ & $5.41 E+08$ \\
\hline ZIO-070 & $1.10 \mathrm{E}-06$ & 9.77E-01 & $1.67 \mathrm{E}+02$ & $3.77 \mathrm{E}+05$ & $4.69 \mathrm{E}+08$ \\
\hline ZIO-071 & $1.00 \mathrm{E}-07$ & $5.27 \mathrm{E}-03$ & $1.28 \mathrm{E}+02$ & $3.10 \mathrm{E}+05$ & $9.31 E+08$ \\
\hline ZIO-100 & $9.70 \mathrm{E}-08$ & $1.13 E+00$ & $2.50 \mathrm{E}+02$ & $5.74 \mathrm{E}+05$ & $7.48 \mathrm{E}+08$ \\
\hline ZIO-101 & $3.80 \mathrm{E}-08$ & $1.36 \mathrm{E}-02$ & $1.36 \mathrm{E}+02$ & $3.30 \mathrm{E}+05$ & $1.14 E+09$ \\
\hline ZIO-103 & $6.50 \mathrm{E}-07$ & $1.10 \mathrm{E}+00$ & $3.24 \mathrm{E}+02$ & $7.47 \mathrm{E}+05$ & $1.43 E+09$ \\
\hline ZIO-104 & $2.20 \mathrm{E}-07$ & 4.64E-02 & $1.48 \mathrm{E}+02$ & $3.61 \mathrm{E}+05$ & $1.45 E+09$ \\
\hline ZIO-106 & $2.90 \mathrm{E}-08$ & $3.11 \mathrm{E}+00$ & $7.78 \mathrm{E}+02$ & $1.33 \mathrm{E}+06$ & $1.94 E+09$ \\
\hline ZIO-107 & $4.20 \mathrm{E}-08$ & $9.25 \mathrm{E}-02$ & $1.54 \mathrm{E}+02$ & $3.75 \mathrm{E}+05$ & $1.66 \mathrm{E}+09$ \\
\hline ZIO-136 & $4.70 \mathrm{E}-07$ & $2.29 \mathrm{E}+00$ & $5.03 \mathrm{E}+02$ & $1.14 \mathrm{E}+06$ & $2.33 \mathrm{E}+09$ \\
\hline ZIO-137 & $2.30 \mathrm{E}-07$ & $1.70 \mathrm{E}-01$ & $1.96 \mathrm{E}+02$ & $4.68 \mathrm{E}+05$ & $1.80 \mathrm{E}+09$ \\
\hline ZIO-139 & $8.10 \mathrm{E}-07$ & $3.18 \mathrm{E}+01$ & $2.79 E+03$ & $3.86 \mathrm{E}+06$ & $2.70 \mathrm{E}+09$ \\
\hline ZIO-140 & $1.40 \mathrm{E}-07$ & $3.97 \mathrm{E}-01$ & $3.06 \mathrm{E}+02$ & $6.78 \mathrm{E}+05$ & $2.13 E+09$ \\
\hline ZIO-142 & $2.90 \mathrm{E}-07$ & $2.34 \mathrm{E}+00$ & $1.10 \mathrm{E}+03$ & $1.90 \mathrm{E}+06$ & $3.04 \mathrm{E}+09$ \\
\hline ZIO-143 & $6.00 \mathrm{E}-08$ & $6.31 \mathrm{E}-01$ & $3.77 \mathrm{E}+02$ & $8.82 \mathrm{E}+05$ & $2.47 \mathrm{E}+09$ \\
\hline $\mathrm{ZIO}-172$ & $4.70 \mathrm{E}-08$ & $1.46 \mathrm{E}+02$ & $4.36 \mathrm{E}+03$ & $7.35 \mathrm{E}+06$ & $2.51 \mathrm{E}+09$ \\
\hline ZIO-173 & $4.90 \mathrm{E}-08$ & $1.28 \mathrm{E}+00$ & $8.64 \mathrm{E}+02$ & $1.42 \mathrm{E}+06$ & $2.57 \mathrm{E}+09$ \\
\hline ZIO-175 & $3.20 \mathrm{E}-07$ & $1.09 \mathrm{E}+02$ & $5.03 E+03$ & $7.32 \mathrm{E}+06$ & $3.80 \mathrm{E}+09$ \\
\hline ZIO-176 & $4.70 \mathrm{E}-08$ & $2.09 \mathrm{E}+00$ & $1.34 \mathrm{E}+03$ & $2.00 \mathrm{E}+06$ & $2.75 \mathrm{E}+09$ \\
\hline $\mathrm{ZIO}-178$ & $1.20 \mathrm{E}-08$ & $3.55 \mathrm{E}+02$ & $8.95 E+03$ & $1.46 \mathrm{E}+07$ & $3.52 E+09$ \\
\hline ZIO-179 & $2.60 \mathrm{E}-08$ & $1.82 \mathrm{E}+01$ & $3.88 \mathrm{E}+03$ & $4.75 E+06$ & $2.84 \mathrm{E}+09$ \\
\hline ZIO-301 & $1.30 \mathrm{E}-04$ & $0.00 \mathrm{E}+00$ & $2.33 \mathrm{E}-02$ & $8.68 \mathrm{E}+01$ & $1.44 \mathrm{E}+03$ \\
\hline $\mathrm{ZIO}-302$ & $1.30 \mathrm{E}-04$ & $0.00 \mathrm{E}+00$ & $9.35 \mathrm{E}-02$ & $3.93 \mathrm{E}+02$ & $2.31 \mathrm{E}+04$ \\
\hline ZIO-303 & $6.20 \mathrm{E}-06$ & $0.00 \mathrm{E}+00$ & $6.65 \mathrm{E}-01$ & $1.84 E+03$ & $1.82 \mathrm{E}+05$ \\
\hline
\end{tabular}


Table 4-18 Zion Consequences to 50 Miles

\begin{tabular}{|c|c|c|c|c|c|}
\hline $\begin{array}{c}\text { Source } \\
\text { Term }\end{array}$ & $\begin{array}{c}\text { Mean } \\
\text { Frequency } \\
(/ \mathbf{y r})\end{array}$ & $\begin{array}{c}\text { Early } \\
\text { Fatalities }\end{array}$ & $\begin{array}{c}\text { Latent } \\
\text { Fatalities }\end{array}$ & $\begin{array}{c}\text { Population } \\
\text { Dose } \\
\text { (Per-rem) }\end{array}$ & $\begin{array}{l}\text { Ofisite } \\
\text { Costs } \\
\text { (\$) }\end{array}$ \\
\hline ZIO-001 & 4.10E-08 & $2.43 \mathrm{E}-01$ & $9.00 \mathrm{E}+01$ & $1.87 \mathrm{E}+05$ & $1.34 E+07$ \\
\hline ZIO-002 & $2.40 \mathrm{E}-08$ & $0.00 \mathrm{E}+00$ & $1.86 \mathrm{E}+02$ & $4.39 \mathrm{E}+05$ & $1.08 \mathrm{E}+08$ \\
\hline ZIO-031 & $7.00 \mathrm{E}-08$ & $7.22 \mathrm{E}-01$ & $1.38 \mathrm{E}+02$ & $2.86 \mathrm{E}+05$ & $2.53 E+07$ \\
\hline ZIO-061 & $2.30 \mathrm{E}-08$ & $7.17 \mathrm{E}-01$ & $1.30 \mathrm{E}+02$ & $2.71 E+05$ & $2.22 \mathrm{E}+07$ \\
\hline ZIO-064 & $2.40 \mathrm{E}-07$ & $6.28 \mathrm{E}-01$ & $2.86 \mathrm{E}+02$ & $6.44 \mathrm{E}+05$ & $1.32 \mathrm{E}+08$ \\
\hline ZIO-065 & $7.50 \mathrm{E}-08$ & $3.75 \mathrm{E}-06$ & $6.80 \mathrm{E}+02$ & $1.61 \mathrm{E}+06$ & $5.90 \mathrm{E}+08$ \\
\hline $\mathrm{ZIO}-066$ & $2.00 \mathrm{E}-07$ & $0.00 \mathrm{E}+00$ & $1.40 \mathrm{E}+02$ & $3.41 E+05$ & $7.89 \mathrm{E}+07$ \\
\hline ZIO-067 & $3.70 \mathrm{E}-07$ & $5.61 E-01$ & $7.18 \mathrm{E}+02$ & $1.68 \mathrm{E}+06$ & $4.58 \mathrm{E}+08$ \\
\hline ZIO-068 & $1.60 \mathrm{E}-07$ & $6.16 \mathrm{E}-04$ & $1.27 \mathrm{E}+03$ & $3.04 \mathrm{E}+06$ & $1.69 E+09$ \\
\hline ZIO-070 & $1.10 \mathrm{E}-06$ & 9.77E-01 & $9.45 E+02$ & $2.31 \mathrm{E}+06$ & $7.25 \mathrm{E}+08$ \\
\hline ZIO-071 & $1.00 \mathrm{E}-07$ & $5.27 \mathrm{E}-03$ & $1.79 \mathrm{E}+03$ & $4.34 \mathrm{E}+06$ & $3.75 \mathrm{E}+09$ \\
\hline ZIO-100 & $9.70 \mathrm{E}-08$ & $1.13 \mathrm{E}+00$ & $1.71 E+03$ & $4.13 E+06$ & $1.88 \mathrm{E}+09$ \\
\hline ZIO-101 & $3.80 \mathrm{E}-08$ & $1.36 \mathrm{E}-02$ & $2.02 \mathrm{E}+03$ & $4.90 \mathrm{E}+06$ & $5.59 \mathrm{E}+09$ \\
\hline ZIO-103 & $6.50 \mathrm{E}-07$ & $1.10 \mathrm{E}+00$ & $2.85 E+03$ & $6.90 \mathrm{E}+06$ & $5.15 E+09$ \\
\hline ZIO-104 & $2.20 \mathrm{E}-07$ & 4.64E-02 & $2.49 \mathrm{E}+03$ & $6.11 \mathrm{E}+06$ & $8.81 \mathrm{E}+09$ \\
\hline ZIO-106 & $2.90 \mathrm{E}-08$ & $3.11 \mathrm{E}+00$ & $4.06 \mathrm{E}+03$ & $9.34 \mathrm{E}+06$ & $1.00 \mathrm{E}+10$ \\
\hline ZIO-107 & $4.20 \mathrm{E}-08$ & $9.25 \mathrm{E}-02$ & $2.87 \mathrm{E}+03$ & $7.09 E+06$ & $1.19 \mathrm{E}+10$ \\
\hline ZIO-136 & $4.70 \mathrm{E}-07$ & $2.29 \mathrm{E}+00$ & $4.08 E+03$ & $9.90 \mathrm{E}+06$ & $1.36 \mathrm{E}+10$ \\
\hline ZIO-137 & $2.30 \mathrm{E}-07$ & $1.70 \mathrm{E}-01$ & $3.13 E+03$ & $7.82 \mathrm{E}+06$ & $1.49 E+10$ \\
\hline ZIO-139 & $8.10 \mathrm{E}-07$ & $3.18 \mathrm{E}+01$ & $7.38 \mathrm{E}+03$ & $1.50 \mathrm{E}+07$ & $1.84 \mathrm{E}+10$ \\
\hline $\mathrm{ZIO}-140$ & $1.40 \mathrm{E}-07$ & $3.97 \mathrm{E}-01$ & $3.93 E+03$ & $9.83 \mathrm{E}+06$ & $2.06 \mathrm{E}+10$ \\
\hline ZIO-142 & $2.90 \mathrm{E}-07$ & $2.34 \mathrm{E}+00$ & $7.15 E+03$ & $1.64 \mathrm{E}+07$ & $2.37 \mathrm{E}+10$ \\
\hline $\mathrm{ZIO}-143$ & $6.00 \mathrm{E}-08$ & $6.31 \mathrm{E}-01$ & $4.65 E+03$ & $1.18 \mathrm{E}+07$ & $2.52 \mathrm{E}+10$ \\
\hline ZIO-172 & $4.70 \mathrm{E}-08$ & $1.46 \mathrm{E}+02$ & $9.92 E+03$ & $2.10 \mathrm{E}+07$ & $2.26 \mathrm{E}+10$ \\
\hline ZIO-173 & $4.90 \mathrm{E}-08$ & $1.28 \mathrm{E}+00$ & $7.68 \mathrm{E}+03$ & $1.69 \mathrm{E}+07$ & $2.77 \mathrm{E}+10$ \\
\hline ZIO-175 & $3.20 \mathrm{E}-07$ & $1.09 \mathrm{E}+02$ & $2.22 \mathrm{E}+04$ & $3.59 \mathrm{E}+07$ & $3.49 \mathrm{E}+10$ \\
\hline $\mathrm{ZIO}-176$ & $4.70 \mathrm{E}-08$ & $2.11 E+00$ & $1.06 \mathrm{E}+04$ & $2.14 \mathrm{E}+07$ & $3.19 \mathrm{E}+10$ \\
\hline ZIO-178 & $1.20 \mathrm{E}-08$ & $3.55 \mathrm{E}+02$ & $2.63 \mathrm{E}+04$ & $4.44 \mathrm{E}+07$ & $3.92 \mathrm{E}+10$ \\
\hline ZIO-179 & $2.60 \mathrm{E}-08$ & $1.93 E+01$ & $2.74 \mathrm{E}+04$ & $4.20 \mathrm{E}+07$ & $3.49 \mathrm{E}+10$ \\
\hline ZIO-301 & $1.30 \mathrm{E}-04$ & $0.00 \mathrm{E}+00$ & $4.87 \mathrm{E}-02$ & $1.78 \mathrm{E}+02$ & $1.44 \mathrm{E}+03$ \\
\hline ZIO-302 & $1.30 \mathrm{E}-04$ & $0.00 \mathrm{E}+00$ & $2.22 \mathrm{E}-01$ & $1.02 \mathrm{E}+03$ & $2.31 \mathrm{E}+04$ \\
\hline ZIO-303 & $6.20 \mathrm{E}-06$ & $0.00 \mathrm{E}+00$ & $1.57 \mathrm{E}+00$ & $5.41 \mathrm{E}+03$ & $1.84 \mathrm{E}+05$ \\
\hline
\end{tabular}


4 Offsite and Onsite Damage Costs

Table 4-19 Zion Consequences to 100 Miles

\begin{tabular}{|c|c|c|c|c|c|}
\hline $\begin{array}{l}\text { Source } \\
\text { Term }\end{array}$ & $\begin{array}{c}\text { Mean } \\
\text { Frequency } \\
\text { (yr) }\end{array}$ & $\begin{array}{c}\text { Early } \\
\text { Fatalities }\end{array}$ & $\begin{array}{c}\text { Latent } \\
\text { Fatalities }\end{array}$ & $\begin{array}{c}\text { Population } \\
\text { Dose } \\
\text { (Per-rem) } \\
\end{array}$ & $\begin{array}{c}\text { Offsite } \\
\text { Costs } \\
(\$)\end{array}$ \\
\hline ZIO-001 & $4.10 \mathrm{E}-08$ & $2.43 \mathrm{E}-01$ & $1.01 \mathrm{E}+02$ & $2.15 \mathrm{E}+05$ & $1.34 \mathrm{E}+07$ \\
\hline ZIO-002 & $2.40 \mathrm{E}-08$ & $0.00 \mathrm{E}+00$ & $2.43 \mathrm{E}+02$ & $5.69 \mathrm{E}+05$ & $1.08 \mathrm{E}+08$ \\
\hline ZIO-031 & $7.00 \mathrm{E}-08$ & $7.22 \mathrm{E}-01$ & $1.58 \mathrm{E}+02$ & $3.38 \mathrm{E}+05$ & $2.53 \mathrm{E}+07$ \\
\hline ZIO-061 & $2.30 \mathrm{E}-08$ & 7.17E-01 & $1.48 \mathrm{E}+02$ & $3.22 \mathrm{E}+05$ & $2.22 \mathrm{E}+07$ \\
\hline ZIO-064 & $2.40 \mathrm{E}-07$ & $6.28 \mathrm{E}-01$ & $3.56 \mathrm{E}+02$ & $8.12 \mathrm{E}+05$ & $1.32 \mathrm{E}+08$ \\
\hline ZIO-065 & $7.50 \mathrm{E}-08$ & $3.75 \mathrm{E}-06$ & $9.52 \mathrm{E}+02$ & $2.22 \mathrm{E}+06$ & $6.05 \mathrm{E}+08$ \\
\hline ZIO-066 & $2.00 \mathrm{E}-07$ & $0.00 \mathrm{E}+00$ & $1.87 \mathrm{E}+02$ & $4.60 \mathrm{E}+05$ & $7.91 \mathrm{E}+07$ \\
\hline ZIO-067 & $3.70 \mathrm{E}-07$ & $5.61 \mathrm{E}-01$ & $9.66 \mathrm{E}+02$ & $2.25 \mathrm{E}+06$ & $4.59 \mathrm{E}+08$ \\
\hline ZIO-068 & $1.60 \mathrm{E}-07$ & $6.16 \mathrm{E}-04$ & $1.93 \mathrm{E}+03$ & $4.49 \mathrm{E}+06$ & $1.73 E+09$ \\
\hline ZIO-070 & $1.10 \mathrm{E}-06$ & 9.77E-01 & $1.30 \mathrm{E}+03$ & $3.15 \mathrm{E}+06$ & $7.39 \mathrm{E}+08$ \\
\hline ZIO-071 & $1.00 \mathrm{E}-07$ & $5.27 \mathrm{E}-03$ & $2.77 \mathrm{E}+03$ & $6.54 \mathrm{E}+06$ & $3.89 \mathrm{E}+09$ \\
\hline ZIO-100 & $9.70 \mathrm{E}-08$ & $1.13 E+00$ & $2.46 \mathrm{E}+03$ & $5.82 \mathrm{E}+06$ & $1.93 \mathrm{E}+09$ \\
\hline ZIO-101 & $3.80 \mathrm{E}-08$ & $1.36 \mathrm{E}-02$ & $3.17 \mathrm{E}+03$ & $7.51 \mathrm{E}+06$ & $6.10 \mathrm{E}+09$ \\
\hline ZIO-103 & $6.50 \mathrm{E}-07$ & $1.10 \mathrm{E}+00$ & $4.23 \mathrm{E}+03$ & $1.01 \mathrm{E}+07$ & $5.43 E+09$ \\
\hline ZIO-104 & $2.20 \mathrm{E}-07$ & $4.64 \mathrm{E}-02$ & $3.88 \mathrm{E}+03$ & $9.31 \mathrm{E}+06$ & $1.06 \mathrm{E}+10$ \\
\hline ZIO-106 & $2.90 \mathrm{E}-08$ & $3.11 \mathrm{E}+00$ & $6.13 E+03$ & $1.41 \mathrm{E}+07$ & $1.13 \mathrm{E}+10$ \\
\hline ZIO-107 & $4.20 \mathrm{E}-08$ & $9.25 \mathrm{E}-02$ & $4.61 E+03$ & $1.11 E+07$ & $1.46 \mathrm{E}+10$ \\
\hline ZIO-136 & $4.70 \mathrm{E}-07$ & $2.29 \mathrm{E}+00$ & $6.45 \mathrm{E}+03$ & $1.54 \mathrm{E}+07$ & $1.63 \mathrm{E}+10$ \\
\hline ZIO-137 & $2.30 \mathrm{E}-07$ & $1.70 \mathrm{E}-01$ & $4.99 \mathrm{E}+03$ & $1.22 \mathrm{E}+07$ & $1.89 \mathrm{E}+10$ \\
\hline ZIO-139 & $8.10 \mathrm{E}-07$ & $3.18 \mathrm{E}+01$ & $9.87 \mathrm{E}+03$ & $2.08 \mathrm{E}+07$ & $2.42 E+10$ \\
\hline ZIO-140 & $1.40 \mathrm{E}-07$ & $3.97 \mathrm{E}-01$ & $5.86 \mathrm{E}+03$ & $1.44 \mathrm{E}+07$ & $2.80 \mathrm{E}+10$ \\
\hline ZIO-142 & $2.90 \mathrm{E}-07$ & $2.34 \mathrm{E}+00$ & $1.02 \mathrm{E}+04$ & $2.36 \mathrm{E}+07$ & $3.28 \mathrm{E}+10$ \\
\hline ZIO-143 & $6.00 \mathrm{E}-08$ & $6.31 \mathrm{E}-01$ & $7.06 \mathrm{E}+03$ & $1.75 \mathrm{E}+07$ & $3.35 \mathrm{E}+10$ \\
\hline ZIO-172 & $4.70 \mathrm{E}-08$ & $1.46 \mathrm{E}+02$ & $1.23 \mathrm{E}+04$ & $2.66 \mathrm{E}+07$ & $3.04 E+10$ \\
\hline ZIO-173 & $4.90 \mathrm{E}-08$ & $1.28 \mathrm{E}+00$ & $1.04 \mathrm{E}+04$ & $2.34 \mathrm{E}+07$ & $3.78 \mathrm{E}+10$ \\
\hline ZIO-175 & $3.20 \mathrm{E}-07$ & $1.09 \mathrm{E}+02$ & $2.80 \mathrm{E}+04$ & $4.73 E+07$ & $4.94 \mathrm{E}+10$ \\
\hline ZIO-176 & $4.70 \mathrm{E}-08$ & $2.11 \mathrm{E}+00$ & $1.39 \mathrm{E}+04$ & $2.91 \mathrm{E}+07$ & $4.31 \mathrm{E}+10$ \\
\hline ZIO-178 & $1.20 \mathrm{E}-08$ & $3.55 \mathrm{E}+02$ & $3.14 \mathrm{E}+04$ & $5.46 \mathrm{E}+07$ & $5.55 \mathrm{E}+10$ \\
\hline ZIO-179 & $2.60 \mathrm{E}-08$ & $1.93 \mathrm{E}+01$ & $3.33 \mathrm{E}+04$ & $5.23 \mathrm{E}+07$ & $4.85 \mathrm{E}+10$ \\
\hline ZIO-301 & $1.30 \mathrm{E}-04$ & $0.00 \mathrm{E}+00$ & $5.81 \mathrm{E}-02$ & $2.18 \mathrm{E}+02$ & $1.44 \mathrm{E}+03$ \\
\hline $\mathrm{ZIO}-302$ & $1.30 \mathrm{E}-04$ & $0.00 \mathrm{E}+00$ & $2.69 \mathrm{E}-01$ & $1.32 \mathrm{E}+03$ & $2.31 E+04$ \\
\hline ZIO-303 & $6.20 \mathrm{E}-06$ & $0.00 \mathrm{E}+00$ & $1.89 \mathrm{E}+00$ & $6.97 \mathrm{E}+03$ & $1.84 \mathrm{E}+05$ \\
\hline
\end{tabular}


Table 4-20 Zion Consequences to 1000 Miles

\begin{tabular}{|c|c|c|c|c|c|}
\hline $\begin{array}{l}\text { Source } \\
\text { Term }\end{array}$ & $\begin{array}{c}\text { Mean } \\
\text { Frequency } \\
\text { (/yr) }\end{array}$ & $\begin{array}{c}\text { Early } \\
\text { Fatalities }\end{array}$ & $\begin{array}{c}\text { Latent } \\
\text { Fatalities }\end{array}$ & $\begin{array}{c}\text { Population } \\
\text { Dose } \\
\text { (Per-rem) }\end{array}$ & $\begin{array}{l}\text { Offsite } \\
\text { Costs } \\
(\$)\end{array}$ \\
\hline ZIO-001 & $4.10 \mathrm{E}-08$ & $2.43 \mathrm{E}-01$ & $1.30 \mathrm{E}+02$ & $2.87 \mathrm{E}+05$ & $1.34 \mathrm{E}+07$ \\
\hline ZIO-002 & $2.40 \mathrm{E}-08$ & $0.00 \mathrm{E}+00$ & $3.97 \mathrm{E}+02$ & $9.07 \mathrm{E}+05$ & $1.08 \mathrm{E}+08$ \\
\hline ZIO-031 & $7.00 \mathrm{E}-08$ & 7.22E-01 & $2.09 \mathrm{E}+02$ & $4.67 \mathrm{E}+05$ & $2.53 \mathrm{E}+07$ \\
\hline ZIO-061 & $2.30 \mathrm{E}-08$ & 7.17E-01 & $1.95 \mathrm{E}+02$ & $4.49 \mathrm{E}+05$ & $2.22 \mathrm{E}+07$ \\
\hline ZIO-064 & $2.40 \mathrm{E}-07$ & $6.28 \mathrm{E}-01$ & $5.35 \mathrm{E}+02$ & $1.24 \mathrm{E}+06$ & $1.32 \mathrm{E}+08$ \\
\hline ZIO-065 & $7.50 \mathrm{E}-08$ & $3.75 \mathrm{E}-06$ & $1.75 \mathrm{E}+03$ & $3.95 \mathrm{E}+06$ & $6.06 \mathrm{E}+08$ \\
\hline ZIO-066 & $2.00 \mathrm{E}-07$ & $0.00 \mathrm{E}+00$ & $2.97 \mathrm{E}+02$ & $7.45 \mathrm{E}+05$ & $7.91 \mathrm{E}+07$ \\
\hline ZIO-067 & $3.70 \mathrm{E}-07$ & $5.61 \mathrm{E}-01$ & $1.61 \mathrm{E}+03$ & $3.73 E+06$ & $4.60 \mathrm{E}+08$ \\
\hline ZIO-068 & $1.60 \mathrm{E}-07$ & $6.16 \mathrm{E}-04$ & $3.89 \mathrm{E}+03$ & $8.72 E+06$ & $1.74 \mathrm{E}+09$ \\
\hline ZIO-070 & $1.10 \mathrm{E}-06$ & $9.77 \mathrm{E}-01$ & $2.33 E+03$ & $5.56 \mathrm{E}+06$ & $7.42 \mathrm{E}+08$ \\
\hline ZIO-071 & $1.00 \mathrm{E}-07$ & $5.27 \mathrm{E}-03$ & $6.47 \mathrm{E}+03$ & $1.44 \mathrm{E}+07$ & $3.91 \mathrm{E}+09$ \\
\hline ZIO-100 & $9.70 \mathrm{E}-08$ & $1.13 E+00$ & $4.62 \mathrm{E}+03$ & $1.06 \mathrm{E}+07$ & $1.94 \mathrm{E}+09$ \\
\hline ZIO-101 & $3.80 \mathrm{E}-08$ & $1.36 \mathrm{E}-02$ & $8.21 E+03$ & $1.82 \mathrm{E}+07$ & $6.13 \mathrm{E}+09$ \\
\hline ZIO-103 & $6.50 \mathrm{E}-07$ & $1.10 \mathrm{E}+00$ & $8.77 \mathrm{E}+03$ & $2.00 \mathrm{E}+07$ & $5.47 \mathrm{E}+09$ \\
\hline ZIO-104 & $2.20 \mathrm{E}-07$ & 4.64E-02 & $1.17 \mathrm{E}+04$ & $2.59 \mathrm{E}+07$ & $1.08 \mathrm{E}+10$ \\
\hline ZIO-106 & $2.90 \mathrm{E}-08$ & $3.11 \mathrm{E}+00$ & $1.38 \mathrm{E}+04$ & $3.09 \mathrm{E}+07$ & $1.15 \mathrm{E}+10$ \\
\hline ZIO-107 & $4.20 \mathrm{E}-08$ & $9.25 \mathrm{E}-02$ & $1.57 \mathrm{E}+04$ & $3.46 \mathrm{E}+07$ & $1.53 \mathrm{E}+10$ \\
\hline ZIO-136 & 4.70E-07 & $2.29 \mathrm{E}+00$ & $1.68 \mathrm{E}+04$ & $3.77 \mathrm{E}+07$ & $1.70 \mathrm{E}+10$ \\
\hline ZIO-137 & $2.30 \mathrm{E}-07$ & $1.70 \mathrm{E}-01$ & $1.88 \mathrm{E}+04$ & 4.17E+07 & $2.02 \mathrm{E}+10$ \\
\hline ZIO-139 & $8.10 \mathrm{E}-07$ & $3.18 \mathrm{E}+01$ & $2.39 \mathrm{E}+04$ & $5.17 \mathrm{E}+07$ & $2.76 \mathrm{E}+10$ \\
\hline ZIO-140 & 1.40E-07 & 3.97E-01 & $2.39 E+04$ & $5.36 \mathrm{E}+07$ & $3.38 \mathrm{E}+10$ \\
\hline ZIO-142 & 2.90E-07 & $2.34 \mathrm{E}+00$ & $3.11 E+04$ & $7.02 \mathrm{E}+07$ & $4.53 \mathrm{E}+10$ \\
\hline ZIO-143 & $6.00 \mathrm{E}-08$ & $6.31 \mathrm{E}-01$ & $2.75 \mathrm{E}+04$ & $6.18 \mathrm{E}+07$ & $4.45 \mathrm{E}+10$ \\
\hline ZIO-172 & 4.70E-08 & $1.46 \mathrm{E}+02$ & $3.13 \mathrm{E}+04$ & $6.89 \mathrm{E}+07$ & $4.28 \mathrm{E}+10$ \\
\hline ZIO-173 & $4.90 \mathrm{E}-08$ & $1.28 \mathrm{E}+00$ & $3.23 E+04$ & $7.23 \mathrm{E}+07$ & $6.05 \mathrm{E}+10$ \\
\hline ZIO-175 & $3.20 \mathrm{E}-07$ & $1.09 \mathrm{E}+02$ & $5.58 \mathrm{E}+04$ & $1.11 \mathrm{E}+08$ & $8.92 \mathrm{E}+10$ \\
\hline ZIO-176 & 4.70E-08 & $2.11 \mathrm{E}+00$ & $3.84 \mathrm{E}+04$ & $8.46 \mathrm{E}+07$ & $7.71 \mathrm{E}+10$ \\
\hline ZIO-178 & $1.20 \mathrm{E}-08$ & $3.55 \mathrm{E}+02$ & $5.95 \mathrm{E}+04$ & $1.19 \mathrm{E}+08$ & $9.77 \mathrm{E}+10$ \\
\hline ZIO-179 & $2.60 \mathrm{E}-08$ & $1.93 \mathrm{E}+01$ & $5.97 \mathrm{E}+04$ & $1.12 \mathrm{E}+08$ & $9.98 \mathrm{E}+10$ \\
\hline ZIO-301 & $1.30 \mathrm{E}-04$ & $0.00 \mathrm{E}+00$ & $8.54 \mathrm{E}-02$ & $3.30 \mathrm{E}+02$ & $1.44 \mathrm{E}+03$ \\
\hline ZIO-302 & 1.30E-04 & $0.00 \mathrm{E}+00$ & 3.73E-01 & $2.06 \mathrm{E}+03$ & $2.31 E+04$ \\
\hline ZIO-303 & $6.20 \mathrm{E}-06$ & $0.00 \mathrm{E}+00$ & $2.65 \mathrm{E}+00$ & $1.10 \mathrm{E}+04$ & $1.84 \mathrm{E}+05$ \\
\hline
\end{tabular}


Table 4-21 Summary of Frequency-Averaged Conditional Consequence Results at NUREG-1150 Plants Out to 10 Miles

\begin{tabular}{||l|c|c|c|c||}
\hline \multicolumn{1}{|c|}{ Plant } & $\begin{array}{c}\text { Average No. } \\
\text { Early } \\
\text { Fatalities }\end{array}$ & $\begin{array}{c}\text { Average No. } \\
\text { Latent } \\
\text { Fatalities }\end{array}$ & $\begin{array}{c}\text { Averaged } \\
\text { Population-Dose } \\
\text { (Per-rem) }\end{array}$ & $\begin{array}{c}\text { Averaged } \\
\text { Offsite Costs } \\
(1990 \$)\end{array}$ \\
\hline \hline Zion & $2.82 \mathrm{E}-01$ & $2.09 \mathrm{E}+01$ & $3.34 \mathrm{E}+04$ & $3.35 \mathrm{E}+07$ \\
\hline Surry & $5.96 \mathrm{E}-02$ & $9.27 \mathrm{E}+00$ & $2.01 \mathrm{E}+04$ & $4.42 \mathrm{E}+07$ \\
\hline Sequoyah & $4.31 \mathrm{E}-01$ & $2.40 \mathrm{E}+01$ & $4.75 \mathrm{E}+04$ & $3.15 \mathrm{E}+07$ \\
\hline Peach Bottom & $6.58 \mathrm{E}-03$ & $3.50 \mathrm{E}+01$ & $6.61 \mathrm{E}+04$ & $1.41 \mathrm{E}+08$ \\
\hline Grand Gulf & $1.50 \mathrm{E}-03$ & $8.07 \mathrm{E}+00$ & $1.68 \mathrm{E}+04$ & $2.79 \mathrm{E}+07$ \\
\hline
\end{tabular}

Table 4-22 Summary of Frequency-Averaged Conditional Consequence Results at NUREG-1150 Plants Out to 50 Miles

\begin{tabular}{||l|c|c|c|c||}
\hline \multicolumn{1}{|c|}{ Plant } & $\begin{array}{c}\text { Average No. } \\
\text { Early } \\
\text { Fatalities }\end{array}$ & $\begin{array}{c}\text { Average No. } \\
\text { Latent } \\
\text { Fatalities }\end{array}$ & $\begin{array}{c}\text { Averaged } \\
\text { Population-Dose } \\
\text { (Per-rem) }\end{array}$ & $\begin{array}{c}\text { Averaged } \\
\text { Offsite Costs } \\
(1990 \text { \$) }\end{array}$ \\
\hline \hline Zion & $2.82 \mathrm{E}-01$ & $9.47 \mathrm{E}+01$ & $1.95 \mathrm{E}+05$ & $2.23 \mathrm{E}+08$ \\
\hline Surry & $6.04 \mathrm{E}-02$ & $6.64 \mathrm{E}+01$ & $1.60 \mathrm{E}+05$ & $2.30 \mathrm{E}+08$ \\
\hline Sequoyah & $4.38 \mathrm{E}-01$ & $1.02 \mathrm{E}+02$ & $2.46 \mathrm{E}+05$ & $3.19 \mathrm{E}+08$ \\
\hline Peach Bottom & $6.82 \mathrm{E}-03$ & $8.14 \mathrm{E}+02$ & $2.00 \mathrm{E}+06$ & $2.71 \mathrm{E}+09$ \\
\hline Grand Gulf & $1.97 \mathrm{E}-03$ & $7.97 \mathrm{E}+01$ & $1.93 \mathrm{E}+05$ & $1.87 \mathrm{E}+08$ \\
\hline
\end{tabular}


Table 4-23 Summary of Frequency-Averaged Conditional Consequence Results at NUREG-1150 Plants Out to 100 Miles

\begin{tabular}{|l|c|c|c|c||}
\hline \multicolumn{1}{|c|}{ Plant } & $\begin{array}{c}\text { Average No. } \\
\text { Early } \\
\text { Fatalities }\end{array}$ & $\begin{array}{c}\text { Average No. } \\
\text { Latent } \\
\text { Fatalities }\end{array}$ & $\begin{array}{c}\text { Averaged } \\
\text { Population-Dose } \\
\text { (Per-rem) }\end{array}$ & $\begin{array}{c}\text { Averaged } \\
\text { Offsite Costs } \\
(\mathbf{1 9 9 0} \$)\end{array}$ \\
\hline \hline Zion & $2.82 \mathrm{E}-01$ & $1.30 \mathrm{E}+02$ & $2.74 \mathrm{E}+05$ & $2.90 \mathrm{E}+08$ \\
\hline Surry & $6.04 \mathrm{E}-02$ & $8.85 \mathrm{E}+01$ & $2.13 \mathrm{E}+05$ & $2.78 \mathrm{E}+08$ \\
\hline Sequoyah & $4.38 \mathrm{E}-01$ & $1.61 \mathrm{E}+02$ & $3.89 \mathrm{E}+05$ & $4.42 \mathrm{E}+08$ \\
\hline Peach Bottom & $6.82 \mathrm{E}-03$ & $1.64 \mathrm{E}+03$ & $4.04 \mathrm{E}+06$ & $4.81 \mathrm{E}+09$ \\
\hline Grand Gulf & $1.97 \mathrm{E}-03$ & $2.30 \mathrm{E}+02$ & $5.59 \mathrm{E}+05$ & $3.69 \mathrm{E}+08$ \\
\hline
\end{tabular}

Table 4-24 Summary of Frequency-Averaged Conditional Consequence Results at NUREG-1150 Plants Out to 1000 Miles

\begin{tabular}{||l|c|c|c|c||}
\hline \multicolumn{1}{|c|}{ Plant } & $\begin{array}{c}\text { Average No. } \\
\text { Early } \\
\text { Fatalities }\end{array}$ & $\begin{array}{c}\text { Average No. } \\
\text { Latent } \\
\text { Fatalities }\end{array}$ & $\begin{array}{c}\text { Averaged } \\
\text { Pop-Dose } \\
\text { (Per-rem) }\end{array}$ & $\begin{array}{c}\text { Averaged } \\
\text { Offsite Costs } \\
(1990 \$)\end{array}$ \\
\hline \hline Zion & $2.82 \mathrm{E}-01$ & $3.14 \mathrm{E}+02$ & $6.82 \mathrm{E}+05$ & $3.88 \mathrm{E}+08$ \\
\hline Surry & $6.04 \mathrm{E}-02$ & $3.92 \mathrm{E}+02$ & $9.23 \mathrm{E}+05$ & $4.27 \mathrm{E}+08$ \\
\hline Sequoyah & $4.38 \mathrm{E}-01$ & $9.56 \mathrm{E}+02$ & $2.20 \mathrm{E}+06$ & $7.34 \mathrm{E}+08$ \\
\hline Peach Bottom & $6.82 \mathrm{E}-03$ & $3.19 \mathrm{E}+03$ & $7.70 \mathrm{E}+06$ & $5.92 \mathrm{E}+09$ \\
\hline Grand Gulf & $1.97 \mathrm{E}-03$ & $1.05 \mathrm{E}+03$ & $2.50 \mathrm{E}+06$ & $5.36 \mathrm{E}+08$ \\
\hline
\end{tabular}


Offsite and Onsite Damage Costs

Table 4-25 Centerline Dose for Grand Gulf Source Terms to Specified Distance

\begin{tabular}{|c|c|c|c|c|}
\hline $\begin{array}{c}\text { Source } \\
\text { Term }\end{array}$ & $\begin{array}{l}\text { Dose at } \\
10 \text { Miles } \\
(\text { Rem) }\end{array}$ & $\begin{array}{l}\text { Dose at } \\
50 \text { Miles } \\
(\text { Rem })\end{array}$ & $\begin{array}{c}\text { Dose at } \\
100 \text { Miles } \\
(\text { Rem) }\end{array}$ & $\begin{array}{l}\text { Dose at } \\
\text { 1000 Miles } \\
\text { (Rem) }\end{array}$ \\
\hline GG01-1 & $1.05 E+00$ & $1.00 \mathrm{E}-01$ & $2.90 \mathrm{E}-02$ & 4.13E-04 \\
\hline GG01-2 & $9.80 \mathrm{E}-01$ & $9.06 \mathrm{E}-02$ & $2.65 \mathrm{E}-02$ & 3.04E-04 \\
\hline GG02-1 & $3.63 E+00$ & $4.54 \mathrm{E}-01$ & $1.58 \mathrm{E}-01$ & 5.12E-04 \\
\hline GG02-2 & $4.13 E+00$ & $5.17 \mathrm{E}-01$ & $1.76 \mathrm{E}-01$ & $4.04 \mathrm{E}-04$ \\
\hline GG03-1 & $4.44 \mathrm{E}+00$ & $2.16 \mathrm{E}+00$ & $7.48 \mathrm{E}-01$ & $8.03 \mathrm{E}-04$ \\
\hline GG03-2 & $3.83 \mathrm{E}+00$ & $1.79 \mathrm{E}+00$ & $6.23 \mathrm{E}-01$ & $5.92 \mathrm{E}-04$ \\
\hline GG04-1 & $4.52 \mathrm{E}+00$ & $1.58 \mathrm{E}+00$ & 5.34E-01 & $5.60 \mathrm{E}-04$ \\
\hline GG04-2 & $4.36 \mathrm{E}+00$ & $1.11 \mathrm{E}+00$ & $3.73 \mathrm{E}-01$ & $3.15 \mathrm{E}-04$ \\
\hline GG05-1 & $6.57 \mathrm{E}+00$ & $8.38 \mathrm{E}+00$ & $2.97 \mathrm{E}+00$ & 1.63E-03 \\
\hline GG05-2 & $6.97 \mathrm{E}+00$ & $4.82 \mathrm{E}+00$ & $1.93 E+00$ & $1.29 \mathrm{E}-03$ \\
\hline GG06-1 & $8.38 \mathrm{E}+00$ & $4.94 \mathrm{E}+00$ & $2.00 \mathrm{E}+00$ & $1.20 \mathrm{E}-03$ \\
\hline GG06-2 & $9.22 \mathrm{E}+00$ & $4.09 \mathrm{E}+00$ & $1.71 \dot{\mathrm{E}}+00$ & $8.28 \mathrm{E}-04$ \\
\hline GG07-1 & $7.02 \mathrm{E}+00$ & $6.09 \mathrm{E}+00$ & $2.39 \mathrm{E}+00$ & $1.69 \mathrm{E}-03$ \\
\hline GG07-2 & $9.42 \mathrm{E}+00$ & $4.49 \mathrm{E}+00$ & $1.89 \mathrm{E}+00$ & $8.95 \mathrm{E}-04$ \\
\hline GG08-1 & $1.32 \mathrm{E}+01$ & $7.09 \mathrm{E}+00$ & $3.78 E+00$ & $2.16 \mathrm{E}-03$ \\
\hline GG08-2 & $9.51 E+00$ & $9.52 \mathrm{E}+00$ & $5.13 \mathrm{E}+00$ & $3.32 \mathrm{E}-03$ \\
\hline GG09-1 & $1.01 \mathrm{E}+01$ & $7.89 \mathrm{E}+00$ & $5.44 \mathrm{E}+00$ & $3.06 \mathrm{E}-03$ \\
\hline GG09-2 & $9.06 \mathrm{E}+00$ & $6.17 E+00$ & $3.95 \mathrm{E}+00$ & $1.59 \mathrm{E}-03$ \\
\hline GG10-1 & $1.18 \mathrm{E}+01$ & $6.24 \mathrm{E}+00$ & $3.91 \mathrm{E}+00$ & $1.85 E-03$ \\
\hline GG11-1 & $4.19 E+00$ & $1.27 \mathrm{E}+01$ & $6.82 \mathrm{E}+00$ & $7.11 \mathrm{E}-03$ \\
\hline GG11-2 & $4.94 E+00$ & $1.61 \mathrm{E}+01$ & $8.75 \mathrm{E}+00$ & $9.56 \mathrm{E}-03$ \\
\hline GG12-1 & $6.79 \mathrm{E}+00$ & $1.20 \mathrm{E}+01$ & $7.21 \mathrm{E}+00$ & $7.18 \mathrm{E}-03$ \\
\hline GG12-2 & $4.77 E+00$ & $9.76 \mathrm{E}+00$ & $6.09 \mathrm{E}+00$ & $5.19 \mathrm{E}-03$ \\
\hline GG15-1 & $3.42 \mathrm{E}-04$ & $1.38 \mathrm{E}-04$ & $4.57 \mathrm{E}-05$ & $1.27 \mathrm{E}-06$ \\
\hline GG16-1 & $1.33 \mathrm{E}-02$ & $2.95 \mathrm{E}-03$ & $9.78 \mathrm{E}-04$ & $1.05 \mathrm{E}-05$ \\
\hline GG17-1 & $2.46 \mathrm{E}-01$ & $4.01 E-02$ & $1.41 \mathrm{E}-02$ & $2.14 \mathrm{E}-04$ \\
\hline GG18-1 & $3.35 \mathrm{E}+00$ & $4.15 \mathrm{E}-01$ & $1.45 \mathrm{E}-01$ & $3.48 \mathrm{E}-04$ \\
\hline GG18-2 & $3.99 \mathrm{E}+00$ & $3.00 \mathrm{E}-01$ & $1.03 \mathrm{E}-01$ & $2.60 \mathrm{E}-04$ \\
\hline GG19-1 & $5.31 \mathrm{E}+00$ & $3.24 \mathrm{E}+00$ & $1.25 \mathrm{E}+00$ & 8.03E-04 \\
\hline GG19-2 & $5.83 E+00$ & $2.25 \mathrm{E}+00$ & 8.53E-01 & $4.72 \mathrm{E}-04$ \\
\hline
\end{tabular}


4 Offsite and Onsite Damage Costs

Table 4-26 Centerline Dose for Peach Bottom Source Terms to Specified Distance

\begin{tabular}{|c|c|c|c|c|}
\hline $\begin{array}{c}\text { Source } \\
\text { Term }\end{array}$ & $\begin{array}{c}\text { Dose at } \\
10 \text { Miles } \\
\text { (Rem) }\end{array}$ & $\begin{array}{c}\text { Dose at } \\
\text { 50 Miles } \\
\text { (Rem) }\end{array}$ & $\begin{array}{c}\text { Dose at } \\
100 \text { Miles } \\
(\text { Rem) }\end{array}$ & $\begin{array}{c}\text { Dose at } \\
1000 \text { Miles } \\
\text { (Rem) }\end{array}$ \\
\hline PB01-1 & $4.13 E+00$ & $4.40 \mathrm{E}-01$ & $1.41 \mathrm{E}-01$ & $1.15 \mathrm{E}-03$ \\
\hline PB01-3 & $4.57 \mathrm{E}+00$ & $2.67 \mathrm{E}-01$ & $6.74 \mathrm{E}-02$ & $6.23 \mathrm{E}-04$ \\
\hline PB02-1 & $5.08 \mathrm{E}+00$ & $3.26 \mathrm{E}+00$ & 9.39E-01 & $3.29 \mathrm{E}-03$ \\
\hline PB02-3 & $5.03 \mathrm{E}+00$ & $2.21 \mathrm{E}+00$ & $5.98 \mathrm{E}-01$ & $2.13 \mathrm{E}-03$ \\
\hline PB03-1 & $4.85 \mathrm{E}+00$ & $1.77 \mathrm{E}+00$ & $5.54 \mathrm{E}-01$ & $2.40 \mathrm{E}-03$ \\
\hline PB03-3 & $5.91 \mathrm{E}+00$ & $1.11 \mathrm{E}+00$ & $3.19 \mathrm{E}-01$ & $1.33 \mathrm{E}-03$ \\
\hline PB04-1 & $4.90 \mathrm{E}+00$ & $1.73 \mathrm{E}+00$ & $5.94 \mathrm{E}-01$ & $2.24 \mathrm{E}-03$ \\
\hline PB04-3 & $5.17 \mathrm{E}+00$ & $1.37 \mathrm{E}+00$ & $3.89 \mathrm{E}-01$ & $1.60 \mathrm{E}-03$ \\
\hline PB05-1 & $5.87 \mathrm{E}+00$ & $8.75 E+00$ & $2.69 \mathrm{E}+00$ & $7.73 \mathrm{E}-03$ \\
\hline PB05-3 & $5.38 \mathrm{E}+00$ & $5.68 \mathrm{E}+00$ & $1.53 \mathrm{E}+00$ & 4.68E-03 \\
\hline PB06-1 & $7.20 \mathrm{E}+00$ & $5.09 \mathrm{E}+00$ & $1.80 \mathrm{E}+00$ & $6.10 \mathrm{E}-03$ \\
\hline PB06-3 & $8.50 \mathrm{E}+00$ & $4.78 \mathrm{E}+00$ & $1.44 \mathrm{E}+00$ & $4.40 \mathrm{E}-03$ \\
\hline PB07-1 & $1.01 \mathrm{E}+01$ & $5.09 \mathrm{E}+00$ & $2.16 \mathrm{E}+00$ & $5.95 \mathrm{E}-03$ \\
\hline PB07-3 & $8.25 \mathrm{E}+00$ & $4.07 \mathrm{E}+00$ & $1.25 \mathrm{E}+00$ & $4.10 \mathrm{E}-03$ \\
\hline PB08-1 & $1.06 \mathrm{E}+01$ & $4.85 \mathrm{E}+00$ & $2.21 \mathrm{E}+00$ & $6.44 \mathrm{E}-03$ \\
\hline PB09-1 & $1.37 \mathrm{E}+01$ & $1.09 \mathrm{E}+01$ & $5.10 \mathrm{E}+00$ & $2.28 \mathrm{E}-02$ \\
\hline PB09-3 & $1.48 \mathrm{E}+01$ & $1.07 \mathrm{E}+01$ & $3.92 \mathrm{E}+00$ & $1.43 \mathrm{E}-02$ \\
\hline PB10-1 & $1.13 \mathrm{E}+01$ & $9.20 \mathrm{E}+00$ & $4.94 \mathrm{E}+00$ & $2.13 \mathrm{E}-02$ \\
\hline PB11-1 & $1.16 \mathrm{E}+01$ & $7.06 \mathrm{E}+00$ & $3.78 \mathrm{E}+00$ & $1.26 \mathrm{E}-02$ \\
\hline PB12-1 & $2.75 \mathrm{E}+00$ & $2.10 \mathrm{E}+01$ & $1.01 \mathrm{E}+01$ & 1.15E-01 \\
\hline PB13-1 & $2.74 \mathrm{E}+00$ & $1.54 \mathrm{E}+01$ & $8.02 E+00$ & $6.78 \mathrm{E}-02$ \\
\hline PB13-3 & $3.20 \mathrm{E}+00$ & $1.27 \mathrm{E}+01$ & $7.20 \mathrm{E}+00$ & $6.48 \mathrm{E}-02$ \\
\hline PB14-1 & $4.22 \mathrm{E}+00$ & $9.17 \mathrm{E}+00$ & $5.52 \mathrm{E}+00$ & $3.10 \mathrm{E}-02$ \\
\hline PB16-1 & $3.61 \mathrm{E}+00$ & $2.87 \mathrm{E}+01$ & $1.32 \mathrm{E}+01$ & $1.70 \mathrm{E}-01$ \\
\hline PB17-1 & $2.35 \mathrm{E}-04$ & $2.05 \mathrm{E}-04$ & 4.57E-05 & $1.79 \mathrm{E}-06$ \\
\hline PB18-1 & $2.85 \mathrm{E}-02$ & $9.45 \mathrm{E}-03$ & $2.23 \mathrm{E}-03$ & $5.46 \mathrm{E}-05$ \\
\hline PB19-1 & $5.14 \mathrm{E}+00$ & $1.05 \mathrm{E}+00$ & $3.23 \mathrm{E}-01$ & $1.44 \mathrm{E}-03$ \\
\hline PB19-3 & $5.74 \mathrm{E}+00$ & $2.77 \mathrm{E}-01$ & 7.19E-02 & 3.30E-04 \\
\hline
\end{tabular}


Table 4-27 Centerline Dose for Sequoyah Source Terms to Specified Distance

\begin{tabular}{|c|c|c|c|c|}
\hline $\begin{array}{c}\text { Source } \\
\text { Term }\end{array}$ & $\begin{array}{c}\text { Dose at } \\
10 \mathrm{Miles} \\
\text { (Rem) }\end{array}$ & $\begin{array}{c}\text { Dose at } \\
50 \text { Miles } \\
\text { (Rem) }\end{array}$ & $\begin{array}{c}\text { Dose at } \\
\text { 100 Miles } \\
\text { (Rem) }\end{array}$ & $\begin{array}{c}\text { Dose at } \\
1000 \text { Miles } \\
\text { (Rem) }\end{array}$ \\
\hline SEQ01-2 & $2.48 \mathrm{E}+00$ & $1.11 \mathrm{E}-01$ & $2.76 \mathrm{E}-02$ & $1.19 \mathrm{E}-03$ \\
\hline SEQ02-1 & $2.06 \mathrm{E}+00$ & $1.07 \mathrm{E}+00$ & 3.24E-01 & $3.85 \mathrm{E}-03$ \\
\hline SEQ02-2 & $6.24 \mathrm{E}+00$ & $3.34 \mathrm{E}-01$ & 8.91E-02 & $1.74 \mathrm{E}-03$ \\
\hline SEQ03-1 & $3.82 \mathrm{E}+00$ & $1.78 \mathrm{E}+00$ & $5.49 \mathrm{E}-01$ & $6.38 \mathrm{E}-03$ \\
\hline SEQ03-2 & $8.95 E+00$ & $1.28 \mathrm{E}+00$ & $3.95 \mathrm{E}-01$ & $4.67 \mathrm{E}-03$ \\
\hline SEQ04-3 & $1.77 \mathrm{E}+01$ & $2.56 \mathrm{E}+00$ & 7.27E-01 & $6.86 \mathrm{E}-03$ \\
\hline SEQ05-1 & $7.91 \mathrm{E}+00$ & $6.24 \mathrm{E}+00$ & $2.28 \mathrm{E}+00$ & $2.46 \mathrm{E}-02$ \\
\hline SEQ05-2 & $2.60 \mathrm{E}+01$ & $5.70 \mathrm{E}+00$ & $1.88 \mathrm{E}+00$ & $2.12 \mathrm{E}-02$ \\
\hline SEQ06-1 & $5.62 \mathrm{E}+00$ & $3.30 \mathrm{E}+00$ & $1.08 \mathrm{E}+00$ & $1.21 \mathrm{E}-02$ \\
\hline SEQ06-2 & $1.28 \mathrm{E}+01$ & $3.36 \mathrm{E}+00$ & $1.10 \mathrm{E}+00$ & $1.10 \mathrm{E}-02$ \\
\hline SEQ07-3 & $4.70 \mathrm{E}+01$ & $9.30 \mathrm{E}+00$ & $5.95 \mathrm{E}+00$ & $6.04 \mathrm{E}-02$ \\
\hline SEQ08-1 & $1.49 \mathrm{E}+01$ & $1.11 \mathrm{E}+01$ & $5.52 \mathrm{E}+00$ & $8.54 \mathrm{E}-02$ \\
\hline SEQ08-2 & $6.07 \mathrm{E}+01$ & $8.84 \mathrm{E}+00$ & $5.82 \mathrm{E}+00$ & 7.44E-02 \\
\hline SEQ08-3 & $3.90 \mathrm{E}+01$ & $6.62 \mathrm{E}+00$ & $3.58 \mathrm{E}+00$ & $3.85 \mathrm{E}-02$ \\
\hline SEQ09-1 & $1.40 \mathrm{E}+01$ & $7.84 \mathrm{E}+00$ & $4.67 \mathrm{E}+00$ & $5.02 \mathrm{E}-02$ \\
\hline SEQ09-2 & $5.27 \mathrm{E}+01$ & $7.57 \mathrm{E}+00$ & $4.22 \mathrm{E}+00$ & $5.13 \mathrm{E}-02$ \\
\hline SEQ10-1 & $1.22 \mathrm{E}+01$ & $6.82 \mathrm{E}+00$ & $2.88 \mathrm{E}+00$ & $3.02 \mathrm{E}-02$ \\
\hline SEQ10-2 & $1.80 \mathrm{E}+01$ & $6.61 \mathrm{E}+00$ & $3.14 \mathrm{E}+00$ & $1.37 \mathrm{E}-02$ \\
\hline SEQ11-1 & $1.34 \mathrm{E}+01$ & $2.03 E+01$ & $1.09 \mathrm{E}+01$ & $2.99 \mathrm{E}-01$ \\
\hline SEQ11-2 & $1.08 \mathrm{E}+02$ & $1.50 \mathrm{E}+01$ & $8.56 \mathrm{E}+00$ & $2.17 \mathrm{E}-01$ \\
\hline SEQ11-3 & $3.24 \mathrm{E}+02$ & $1.86 \mathrm{E}+01$ & $9.71 \mathrm{E}+00$ & $2.56 \mathrm{E}-01$ \\
\hline SEQ12-1 & $6.49 \mathrm{E}+00$ & $1.18 \mathrm{E}+01$ & $7.05 \mathrm{E}+00$ & $1.49 \mathrm{E}-01$ \\
\hline SEQ12-2 & $8.50 \mathrm{E}+01$ & $1.22 \mathrm{E}+01$ & $7.84 \mathrm{E}+00$ & $1.34 \mathrm{E}-01$ \\
\hline SEQ13-1 & $1.60 \mathrm{E}+01$ & $9.89 \mathrm{E}+00$ & $5.66 \mathrm{E}+00$ & $8.14 \mathrm{E}-02$ \\
\hline SEQ13-2 & $4.41 \mathrm{E}+01$ & $7.74 \mathrm{E}+00$ & $6.09 \mathrm{E}+00$ & 7.33E-02 \\
\hline SEQ14-2 & $5.48 \mathrm{E}+02$ & $3.23 \mathrm{E}+01$ & $1.74 \mathrm{E}+01$ & $8.53 \mathrm{E}-01$ \\
\hline SEQ14-3 & $1.03 E+03$ & $3.65 \mathrm{E}+01$ & $1.83 E+01$ & $7.80 \mathrm{E}-01$ \\
\hline SEQ15-1 & $1.76 \mathrm{E}+01$ & $1.98 \mathrm{E}+01$ & $9.73 E+00$ & $3.42 \mathrm{E}-01$ \\
\hline SEQ15-2 & $2.30 \mathrm{E}+02$ & $2.14 \mathrm{E}+01$ & $1.11 \mathrm{E}+01$ & 4.86E-01 \\
\hline SEQ16-1 & $4.18 \mathrm{E}-04$ & $1.90 \mathrm{E}-04$ & $5.53 \mathrm{E}-05$ & $2.04 \mathrm{E}-06$ \\
\hline SEQ17-1 & $5.83 \mathrm{E}-03$ & $2.15 \mathrm{E}-03$ & $6.02 \mathrm{E}-04$ & $1.87 \mathrm{E}-05$ \\
\hline SEQ17-2 & $2.98 \mathrm{E}-01$ & $3.58 \mathrm{E}-02$ & $8.29 \mathrm{E}-03$ & $3.76 \mathrm{E}-04$ \\
\hline SEQ18-1 & $3.06 \mathrm{E}+00$ & $4.92 \mathrm{E}-01$ & $1.38 \mathrm{E}-01$ & $1.26 \mathrm{E}-03$ \\
\hline SEQ18-2 & $6.22 \mathrm{E}+00$ & $6.96 \mathrm{E}-01$ & $2.03 \mathrm{E}-01$ & $1.95 \mathrm{E}-03$ \\
\hline
\end{tabular}


4 Offsite and Onsite Damage Costs

Table 4-28 Centerline Dose for Surry Source Terms to Specified Distance

\begin{tabular}{|c|c|c|c|c|}
\hline $\begin{array}{c}\text { Source } \\
\text { Term }\end{array}$ & $\begin{array}{c}\text { Dose at } \\
10 \text { Miles } \\
\text { (Rem) }\end{array}$ & $\begin{array}{c}\text { Dose at } \\
50 \text { Miles } \\
\text { (Rem) }\end{array}$ & $\begin{array}{l}\text { Dose at } \\
100 \text { Miles } \\
\text { (Rem) }\end{array}$ & $\begin{array}{c}\text { Dose at } \\
1000 \text { Miles } \\
\text { (Rem) }\end{array}$ \\
\hline SUR01-3 & $7.83 E+00$ & 3.07E-01 & $7.98 \mathrm{E}-02$ & 7.64E-04 \\
\hline SUR02-2 & $4.30 \mathrm{E}+01$ & $9.81 \mathrm{E}+00$ & $4.89 \mathrm{E}+00$ & $4.65 \mathrm{E}-02$ \\
\hline SUR02-3 & $1.22 \mathrm{E}+01$ & $2.53 E+00$ & $8.76 \mathrm{E}-01$ & $4.78 \mathrm{E}-03$ \\
\hline SUR03-2 & $4.91 \mathrm{E}+01$ & $1.29 \mathrm{E}+01$ & $6.76 \mathrm{E}+00$ & $6.72 \mathrm{E}-02$ \\
\hline SUR03-3 & $2.86 \mathrm{E}+01$ & $6.18 \mathrm{E}+00$ & $3.43 \mathrm{E}+00$ & $2.11 \mathrm{E}-02$ \\
\hline SUR04-1 & $9.17 \mathrm{E}+00$ & $7.40 \mathrm{E}+00$ & $4.17 \mathrm{E}+00$ & $3.12 \mathrm{E}-02$ \\
\hline SUR04-2 & $1.59 \mathrm{E}+01$ & $6.86 \mathrm{E}+00$ & $3.93 E+00$ & $1.53 \mathrm{E}-02$ \\
\hline SUR05-3 & $6.51 E+01$ & $1.25 \mathrm{E}+01$ & $6.38 \mathrm{E}+00$ & 1.02E-01 \\
\hline SUR06-3 & $6.14 \mathrm{E}+01$ & $1.08 \mathrm{E}+01$ & $6.37 \mathrm{E}+00$ & 8.63E-02 \\
\hline SUR07-1 & $6.85 \mathrm{E}+00$ & $1.96 \mathrm{E}+01$ & $9.26 \mathrm{E}+00$ & $1.66 \mathrm{E}-01$ \\
\hline SUR07-2 & $8.73 E+01$ & $1.87 \mathrm{E}+01$ & $9.99 \mathrm{E}+00$ & $1.32 \mathrm{E}-01$ \\
\hline SUR07-3 & $4.05 \mathrm{E}+01$ & $8.62 E+00$ & $5.20 \mathrm{E}+00$ & 4.54E-02 \\
\hline SUR08-1 & $4.99 \mathrm{E}+00$ & $1.03 E+01$ & $6.16 \mathrm{E}+00$ & $9.58 \mathrm{E}-02$ \\
\hline SUR08-2 & $1.46 \mathrm{E}+01$ & $1.06 \mathrm{E}+01$ & $6.82 \mathrm{E}+00$ & $6.48 \mathrm{E}-02$ \\
\hline SUR09-1 & $4.79 \mathrm{E}+00$ & $8.94 \mathrm{E}+00$ & $6.05 \mathrm{E}+00$ & $6.04 \mathrm{E}-02$ \\
\hline SUR09-2 & $1.48 \mathrm{E}+01$ & $8.34 \mathrm{E}+00$ & $5.14 \mathrm{E}+00$ & $2.89 \mathrm{E}-02$ \\
\hline SUR10-3 & $1.30 \mathrm{E}+02$ & $1.65 \mathrm{E}+01$ & $9.30 \mathrm{E}+00$ & 1.82E-01 \\
\hline SUR11-1 & $9.07 \mathrm{E}+00$ & $3.12 \mathrm{E}+01$ & $1.38 \mathrm{E}+01$ & 3.38E-01 \\
\hline SUR11-2 & $2.61 E+01$ & $2.23 E+01$ & $1.35 \mathrm{E}+01$ & 2.96E-01 \\
\hline SUR11-3 & $9.50 \mathrm{E}+01$ & $1.37 \mathrm{E}+01$ & $6.93 E+00$ & $1.26 \mathrm{E}-01$ \\
\hline SUR12-1 & $6.72 \mathrm{E}+00$ & $1.93 \mathrm{E}+01$ & $1.05 \mathrm{E}+01$ & $2.07 \mathrm{E}-01$ \\
\hline SUR12-2 & $3.28 \mathrm{E}+01$ & $1.56 \mathrm{E}+01$ & $9.53 \mathrm{E}+00$ & $1.57 \mathrm{E}-01$ \\
\hline SUR13-1 & $6.09 \mathrm{E}+00$ & $1.40 \mathrm{E}+01$ & $7.59 \mathrm{E}+00$ & 1.51E-01 \\
\hline SUR14-1 & $5.67 \mathrm{E}+00$ & $1.18 \mathrm{E}+01$ & $6.41 E+00$ & $1.20 \mathrm{E}-01$ \\
\hline SUR15-1 & $2.85 \mathrm{E}-04$ & $8.14 \mathrm{E}-05$ & $2.53 \mathrm{E}-05$ & 8.33E-07 \\
\hline SUR16-1 & $4.15 \mathrm{E}-03$ & 8.14E-04 & $2.41 \mathrm{E}-04$ & $4.51 \mathrm{E}-06$ \\
\hline SUR17-1 & $5.45 \mathrm{E}+00$ & $1.05 \mathrm{E}+00$ & $3.21 \mathrm{E}-01$ & $1.97 \mathrm{E}-03$ \\
\hline SUR17-2 & $8.50 \mathrm{E}+00$ & $3.51 \mathrm{E}+00$ & $1.24 \mathrm{E}+00$ & $6.10 \mathrm{E}-03$ \\
\hline
\end{tabular}


4 Offsite and Onsite Damage Costs

Table 4-29 Centerline Dose for Zion Source Terms to Specified Distance

\begin{tabular}{|c|c|c|c|c|}
\hline $\begin{array}{l}\text { Source } \\
\text { Term }\end{array}$ & $\begin{array}{c}\text { Dose at } \\
10 \text { Miles } \\
\text { (Rem) }\end{array}$ & $\begin{array}{c}\text { Dose at } \\
\text { 50 Miles } \\
\text { (Rem) }\end{array}$ & $\begin{array}{c}\text { Dose at } \\
100 \text { Miles } \\
\text { (Rem) }\end{array}$ & $\begin{array}{l}\text { Dose at } \\
\text { 1000 Miles } \\
\text { (Rem) }\end{array}$ \\
\hline ZION-001 & $4.13 E+00$ & $1.25 \mathrm{E}-01$ & $3.12 \mathrm{E}-02$ & 8.92E-04 \\
\hline ZION-002 & $4.07 \mathrm{E}+00$ & $3.08 \mathrm{E}-01$ & $9.87 \mathrm{E}-02$ & 8.57E-04 \\
\hline ZION-031 & $5.96 \mathrm{E}+00$ & $1.89 \mathrm{E}-01$ & $5.02 \mathrm{E}-02$ & $1.09 \mathrm{E}-03$ \\
\hline ZION-061 & $5.75 \mathrm{E}+00$ & $1.85 \mathrm{E}-01$ & $4.87 \mathrm{E}-02$ & $1.08 \mathrm{E}-03$ \\
\hline ZION-064 & $8.42 \mathrm{E}+00$ & 4.54E- 01 & $1.40 \mathrm{E}-01$ & $1.65 \mathrm{E}-03$ \\
\hline ZION-065 & $4.94 \mathrm{E}+00$ & $1.48 \mathrm{E}+00$ & $5.10 \mathrm{E}-01$ & 3.63E-03 \\
\hline ZION-066 & $3.41 \mathrm{E}+00$ & $2.07 \mathrm{E}-01$ & $7.01 \mathrm{E}-02$ & $7.55 \mathrm{E}-04$ \\
\hline ZION-067 & $1.09 \mathrm{E}+01$ & $1.35 \mathrm{E}+00$ & $4.46 \mathrm{E}-01$ & $3.52 \mathrm{E}-03$ \\
\hline ZION-068 & $7.23 \mathrm{E}+00$ & $3.54 \mathrm{E}+00$ & $1.29 \mathrm{E}+00$ & $8.73 E-03$ \\
\hline ZION-070 & $1.16 \mathrm{E}+01$ & $2.04 \mathrm{E}+00$ & $6.81 \mathrm{E}-01$ & 4.99E-03 \\
\hline ZION-071 & $1.07 \mathrm{E}+01$ & $5.47 \mathrm{E}+00$ & $2.47 \mathrm{E}+00$ & $1.68 \mathrm{E}-02$ \\
\hline ZION-100 & $2.00 \mathrm{E}+01$ & $4.56 \mathrm{E}+00$ & $1.59 \mathrm{E}+00$ & $1.07 \mathrm{E}-02$ \\
\hline ZION-101 & $1.11 \mathrm{E}+01$ & $6.67 \mathrm{E}+00$ & $3.44 \mathrm{E}+00$ & $2.34 \mathrm{E}-02$ \\
\hline ZION-103 & $2.33 \mathrm{E}+01$ & $6.57 \mathrm{E}+00$ & $3.36 \mathrm{E}+00$ & $2.17 \mathrm{E}-02$ \\
\hline ZION-104 & $1.00 \mathrm{E}+01$ & $7.13 E+00$ & $4.96 \mathrm{E}+00$ & 4.07E-02 \\
\hline ZION-106 & $4.58 \mathrm{E}+01$ & $8.24 \mathrm{E}+00$ & $4.83 E+00$ & $4.00 \mathrm{E}-02$ \\
\hline ZION-107 & $6.07 \mathrm{E}+00$ & $8.00 \mathrm{E}+00$ & $5.60 \mathrm{E}+00$ & $6.21 \mathrm{E}-02$ \\
\hline ZION-136 & $3.80 \mathrm{E}+01$ & $8.67 \mathrm{E}+00$ & $5.82 \mathrm{E}+00$ & $5.29 \mathrm{E}-02$ \\
\hline ZION-137 & $6.68 \mathrm{E}+00$ & $8.60 \mathrm{E}+00$ & $6.50 \mathrm{E}+00$ & 8.71E-02 \\
\hline ZION-139 & $2.02 \mathrm{E}+02$ & $1.25 \mathrm{E}+01$ & $7.44 \mathrm{E}+00$ & $1.10 \mathrm{E}-01$ \\
\hline ZION-140 & $8.85 \mathrm{E}+00$ & $1.14 \mathrm{E}+01$ & $6.64 \mathrm{E}+00$ & $1.55 \mathrm{E}-01$ \\
\hline ZION-142 & $4.24 \mathrm{E}+01$ & $1.26 \mathrm{E}+01$ & $7.27 \mathrm{E}+00$ & $1.52 \mathrm{E}-01$ \\
\hline ZION-143 & $1.06 \mathrm{E}+01$ & $1.31 \mathrm{E}+01$ & $6.89 \mathrm{E}+00$ & $2.23 \mathrm{E}-01$ \\
\hline ZION-172 & $3.16 \mathrm{E}+02$ & $1.87 \mathrm{E}+01$ & $9.59 \mathrm{E}+00$ & 2.27E-01 \\
\hline ŻION-173 & $1.79 \mathrm{E}+01$ & $2.03 E+01$ & $1.04 \mathrm{E}+01$ & $3.30 \mathrm{E}-01$ \\
\hline ZION-175 & $1.97 \mathrm{E}+02$ & $2.88 \mathrm{E}+01$ & $1.39 \mathrm{E}+01$ & $4.54 \mathrm{E}-01$ \\
\hline ZION-176 & $2.44 \mathrm{E}+01$ & $2.75 \mathrm{E}+01$ & $1.37 \mathrm{E}+01$ & $4.61 \mathrm{E}-01$ \\
\hline ZION-178 & $7.13 \mathrm{E}+02$ & $3.64 \mathrm{E}+01$ & $1.71 \mathrm{E}+01$ & $5.73 \mathrm{E}-01$ \\
\hline ZION-179 & $6.76 \mathrm{E}+01$ & $5.80 \mathrm{E}+01$ & $2.17 \mathrm{E}+01$ & 9.37E-01 \\
\hline ZION-301 & 5.33E-04 & $1.04 \mathrm{E}-04$ & $3.28 \mathrm{E}-05$ & $1.64 \mathrm{E}-06$ \\
\hline ZION-302 & $2.69 \mathrm{E}-03$ & $4.10 \mathrm{E}-04$ & $1.26 \mathrm{E}-04$ & 2.19E-06 \\
\hline ZION-303 & $2.51 \mathrm{E}-02$ & $2.75 \mathrm{E}-03$ & 8.51E-04 & $1.76 \mathrm{E}-05$ \\
\hline
\end{tabular}


Table 4-30 Frequency-Averaged Conditional Consequences at Grand Gulf Out to 50 Miles as a Function of Long-Term Interdiction Limit

\begin{tabular}{|c|c|c|c|}
\hline $\begin{array}{c}\text { Interdiction Limit } \\
\text { (mrem/yr) }\end{array}$ & $\begin{array}{c}\text { Average Latent } \\
\text { Cancers }\end{array}$ & $\begin{array}{c}\text { Average Dose } \\
\text { (Per-rem) }\end{array}$ & $\begin{array}{c}\text { Average Cost } \\
\text { (\$) }\end{array}$ \\
\hline \hline 300 & $6.41 \mathrm{E}+01$ & $1.55 \mathrm{E}+05$ & $2.98 \mathrm{E}+08$ \\
\hline 500 & $7.14 \mathrm{E}+01$ & $1.72 \mathrm{E}+05$ & $2.35 \mathrm{E}+08$ \\
\hline 700 & $7.71 \mathrm{E}+01$ & $1.86 \mathrm{E}+05$ & $2.00 \mathrm{E}+08$ \\
\hline 800 & $7.97 \mathrm{E}+01$ & $1.93 \mathrm{E}+05$ & $1.87 \mathrm{E}+08$ \\
\hline
\end{tabular}

Table 4-31 Frequency-Averaged Conditional Consequences at Peach Bottom Out to 50 Miles as a Function of Long-Term Interdiction Limit

\begin{tabular}{|c|c|c|c|}
\hline $\begin{array}{c}\text { Interdiction Limit } \\
\text { (mrem/yr) }\end{array}$ & $\begin{array}{c}\text { Average Latent } \\
\text { Cancers }\end{array}$ & $\begin{array}{c}\text { Average Dose } \\
\text { (Per-rem) }\end{array}$ & $\begin{array}{c}\text { Average Cost } \\
\text { (\$) }\end{array}$ \\
\hline \hline 300 & $5.75 \mathrm{E}+02$ & $1.41 \mathrm{E}+06$ & $5.15 \mathrm{E}+09$ \\
\hline 500 & $6.82 \mathrm{E}+02$ & $1.67 \mathrm{E}+06$ & $3.71 \mathrm{E}+09$ \\
\hline 700 & $7.70 \mathrm{E}+02$ & $1.89 \mathrm{E}+06$ & $2.97 \mathrm{E}+09$ \\
\hline 800 & $8.14 \mathrm{E}+02$ & $2.00 \mathrm{E}+06$ & $2.71 \mathrm{E}+09$ \\
\hline
\end{tabular}


Table 4-32 Frequency-Averaged Conditional Consequences at Sequoyah Out to 50 Miles as a Function of Long-Term Interdiction Limit

\begin{tabular}{||c|c|c|c||}
\hline $\begin{array}{c}\text { Interdiction Limit } \\
(\mathbf{m r e m} / \mathbf{y r})\end{array}$ & $\begin{array}{c}\text { Average Latent } \\
\text { Cancers }\end{array}$ & $\begin{array}{c}\text { Average Dose } \\
\text { (Per-rem) }\end{array}$ & $\begin{array}{c}\text { Average Cost } \\
\mathbf{( \$ )}\end{array}$ \\
\hline \hline 300 & $7.89 \mathrm{E}+01$ & $1.89 \mathrm{E}+05$ & $5.13 \mathrm{E}+08$ \\
\hline 500 & $8.89 \mathrm{E}+01$ & $2.13 \mathrm{E}+05$ & $4.04 \mathrm{E}+08$ \\
\hline 700 & $9.72 \mathrm{E}+01$ & $2.34 \mathrm{E}+05$ & $3.42 \mathrm{E}+08$ \\
\hline 800 & $1.02 \mathrm{E}+02$ & $2.46 \mathrm{E}+05$ & $3.19 \mathrm{E}+08$ \\
\hline
\end{tabular}

Table 4-33 Frequency-Averaged Conditional Consequences at Surry Out to 50 Miles as a Function of Long-Term Interdiction Limit

\begin{tabular}{|c|c|c|c|}
\hline $\begin{array}{c}\text { Interdiction Limit } \\
(\mathbf{m r e m} / \mathbf{y r})\end{array}$ & $\begin{array}{c}\text { Average Latent } \\
\text { Cancers }\end{array}$ & $\begin{array}{c}\text { Average Dose } \\
\text { (Per-rem) }\end{array}$ & $\begin{array}{c}\text { Average Cost } \\
\text { (\$) }\end{array}$ \\
\hline \hline 300 & $4.86 \mathrm{E}+01$ & $1.17 \mathrm{E}+05$ & $4.22 \mathrm{E}+08$ \\
\hline 500 & $5.70 \mathrm{E}+01$ & $1.37 \mathrm{E}+05$ & $3.08 \mathrm{E}+08$ \\
\hline 700 & $6.36 \mathrm{E}+01$ & $1.54 \mathrm{E}+05$ & $2.52 \mathrm{E}+08$ \\
\hline 800 & $6.64 \mathrm{E}+01$ & $1.60 \mathrm{E}+05$ & $2.30 \mathrm{E}+08$ \\
\hline
\end{tabular}


Table 4-34 Frequency-Averaged Conditional Consequences at Zion Out to 50 Miles as a Function of Long-Term Interdiction Limit

\begin{tabular}{||c|c|c|c|}
\hline $\begin{array}{c}\text { Interdiction Limit } \\
\text { (mrem/yr) }\end{array}$ & $\begin{array}{c}\text { Average Latent } \\
\text { Cancers }\end{array}$ & $\begin{array}{c}\text { Average Dose } \\
\text { (Per-rem) }\end{array}$ & $\begin{array}{c}\text { Average Cost } \\
\text { (\$) }\end{array}$ \\
\hline \hline 300 & $7.34 \mathrm{E}+01$ & $1.43 \mathrm{E}+05$ & $4.02 \mathrm{E}+08$ \\
\hline 500 & $8.26 \mathrm{E}+01$ & $1.66 \mathrm{E}+05$ & $2.96 \mathrm{E}+08$ \\
\hline 700 & $9.02 \mathrm{E}+01$ & $1.84 \mathrm{E}+05$ & $2.41 \mathrm{E}+08$ \\
\hline 800 & $9.47 \mathrm{E}+01$ & $1.95 \mathrm{E}+05$ & $2.23 \mathrm{E}+08$ \\
\hline
\end{tabular}

Table 4-35 Frequency-Averaged Conditional Consequences at Grand Gulf Out to 1000 Miles as a Function of Long-Term Interdiction Limit

\begin{tabular}{|c|c|c|c|}
\hline $\begin{array}{c}\text { Interdiction Limit } \\
\text { (mrem/yr) }\end{array}$ & $\begin{array}{c}\text { Average Latent } \\
\text { Cancers }\end{array}$ & $\begin{array}{c}\text { Average Dose } \\
\text { (Per-rem) }\end{array}$ & $\begin{array}{c}\text { Average Cost } \\
\text { (\$) }\end{array}$ \\
\hline \hline 300 & $9.79 \mathrm{E}+02$ & $2.33 \mathrm{E}+06$ & $1.06 \mathrm{E}+09$ \\
\hline 500 & $1.01 \mathrm{E}+03$ & $2.42 \mathrm{E}+06$ & $7.24 \mathrm{E}+08$ \\
\hline 700 & $1.04 \mathrm{E}+03$ & $2.48 \mathrm{E}+06$ & $5.77 \mathrm{E}+08$ \\
\hline 800 & $1.05 \mathrm{E}+03$ & $2.50 \mathrm{E}+06$ & $5.36 \mathrm{E}+08$ \\
\hline
\end{tabular}


4 Offsite and Onsite Damage Costs

Table 4-36 Frequency-Averaged Conditional Consequences at Peach Bottom Out to 1000 Miles as a Function of Long-Term Interdiction Limit

\begin{tabular}{|c|c|c|c|}
\hline $\begin{array}{c}\text { Interdiction Limit } \\
\text { (mrem/yr) }\end{array}$ & $\begin{array}{c}\text { Average Latent } \\
\text { Cancers }\end{array}$ & $\begin{array}{c}\text { Average Dose } \\
\text { (Per-rem) }\end{array}$ & $\begin{array}{c}\text { Average Cost } \\
\text { (\$) }\end{array}$ \\
\hline \hline 300 & $2.44 \mathrm{E}+03$ & $5.85 \mathrm{E}+06$ & $1.25 \mathrm{E}+10$ \\
\hline 500 & $2.78 \mathrm{E}+03$ & $6.71 \mathrm{E}+06$ & $8.59 \mathrm{E}+09$ \\
\hline 700 & $3.08 \mathrm{E}+03$ & $7.44 \mathrm{E}+06$ & $6.50 \mathrm{E}+09$ \\
\hline 800 & $3.19 \mathrm{E}+03$ & $7.70 \mathrm{E}+06$ & $5.92 \mathrm{E}+09$ \\
\hline
\end{tabular}

Table 4-37 Frequency-Averaged Conditional Consequences at Sequoyah Out to 1000 Miles as a Function of Long-Term Interdiction Limit

\begin{tabular}{|c|c|c|c|}
\hline $\begin{array}{c}\text { Interdiction Limit } \\
\text { (mrem/yr) }\end{array}$ & $\begin{array}{c}\text { Average Latent } \\
\text { Cancers }\end{array}$ & $\begin{array}{c}\text { Average Dose } \\
\text { (Per-rem) }\end{array}$ & $\begin{array}{c}\text { Average Cost } \\
\text { (\$) }\end{array}$ \\
\hline \hline 300 & $8.40 \mathrm{E}+02$ & $1.92 \mathrm{E}+06$ & $1.63 \mathrm{E}+09$ \\
\hline 500 & $8.96 \mathrm{E}+02$ & $2.06 \mathrm{E}+06$ & $1.07 \mathrm{E}+09$ \\
\hline 700 & $9.37 \mathrm{E}+02$ & $2.16 \mathrm{E}+06$ & $7.96 \mathrm{E}+08$ \\
\hline 800 & $9.56 \mathrm{E}+02$ & $2.20 \mathrm{E}+06$ & $7.34 \mathrm{E}+08$ \\
\hline
\end{tabular}


Table 4-38 Frequency-Averaged Conditional Consequences at Surry Out to 1000 Miles as a Function of Long-Term Interdiction Limit

\begin{tabular}{|c|c|c|c|}
\hline $\begin{array}{c}\text { Interdiction Limit } \\
\text { (mrem/yr) }\end{array}$ & $\begin{array}{c}\text { Average Latent } \\
\text { Cancers }\end{array}$ & $\begin{array}{c}\text { Average Dose } \\
\text { (Per-rem) }\end{array}$ & $\begin{array}{c}\text { Average Cost } \\
\text { (\$) }\end{array}$ \\
\hline \hline 300 & $3.22 \mathrm{E}+02$ & $7.54 \mathrm{E}+05$ & $1.07 \mathrm{E}+09$ \\
\hline 500 & $3.59 \mathrm{E}+02$ & $8.43 \mathrm{E}+05$ & $6.57 \mathrm{E}+08$ \\
\hline 700 & $3.82 \mathrm{E}+02$ & $8.98 \mathrm{E}+05$ & $4.90 \mathrm{E}+08$ \\
\hline 800 & $3.92 \mathrm{E}+02$ & $9.23 \mathrm{E}+05$ & $4.27 \mathrm{E}+08$ \\
\hline
\end{tabular}

Table 4-39 Frequency-Averaged Conditional Consequences at Zion Out to 1000 Miles as a Function of Long-Term Interdiction Limit

\begin{tabular}{|c|c|c|c|}
\hline $\begin{array}{c}\text { Interdiction Limit } \\
(\mathbf{m r e m} / \mathbf{y r})\end{array}$ & $\begin{array}{c}\text { Average Latent } \\
\text { Cancers }\end{array}$ & $\begin{array}{c}\text { Average Dose } \\
\text { (Per-Rem) }\end{array}$ & $\begin{array}{c}\text { Average Cost } \\
\text { (\$) }\end{array}$ \\
\hline \hline 300 & $2.23 \mathrm{E}+02$ & $4.83 \mathrm{E}+05$ & $7.53 \mathrm{E}+08$ \\
\hline 500 & $2.43 \mathrm{E}+02$ & $5.30 \mathrm{E}+05$ & $5.32 \mathrm{E}+08$ \\
\hline 700 & $2.57 \mathrm{E}+02$ & $5.65 \mathrm{E}+05$ & $4.29 \mathrm{E}+08$ \\
\hline 800 & $3.14 \mathrm{E}+02$ & $6.82 \mathrm{E}+05$ & $3.88 \mathrm{E}+08$ \\
\hline
\end{tabular}




\subsection{SUMMARY OF RESULTS}

In this chapter, we bring together the information and data presented in earlier chapters on the monetary evaluation of a person-rem of avoided dose under various approaches. We summarize the information presented earlier on the statistical-valueof-life (SVOL) and inferred dollars per person-rem for both public exposure and worker exposure health related risks obtained from studies based on the willingness-to-pay approach. We also summarize the values of dollars per person-rem for health related risks based on the loss of human capital approach. For reactor backfits, where the possibility of extensive offsite damage costs has to be considered, we provide a range of values of the offsite costs per person-rem averted obtained at the minimum of the total cost curve as described in section 4.1.5 in Chapter 4.

As shown in Chapter 3, based on the published data there is a large range of values of SVOL depending on the kinds of risks avoided, the nature of actions taken, and the scope and author of the study. Selection of a particular value for SVOL undoubtedly involves a subjective judgement; no representation is made in this report that any particular value is recommended by BNL or the NRC. Illustrative examples of inferred 1990 dollars per person-rem for any selected SVOL are shown in Table 5-1. Figure 5-1 provides a convenient nomogram for reading off a 1990 dollar per personrem value for any selected estimate of SVOL based on the two discount rates, $7 \%$ and $3 \%$, recommended in the Draft Regulatory Analysis Guidelines of the NRC. (Both Table 5-1 and Figure 5-1 include the factor of discounting to present value, at the appropriate discount rate, over the latency period of induction of various types of cancer after exposure to low dose, low LET radiation as shown in Table $2-1$ above).
An estimate of an appropriate value for averted radiation dose, dollars per person-rem, based on health risk depends on two factors:

the risk of latent health effects per person-

rem; and

the dollar value assigned to the SVOL.

From the viewpoint of the NRC, most of the uncertainty lies in the assignment of a value to the SVOL, rather than to the radiation risk coefficients, since other national and international authorities are charged with the task of evaluating dose/risk relationships.

Table 5-2 presents the range of values of the SVOL and the inferred dollars per person-rem based on the willingness-to-pay approach for both the public and the worker health related risks. All dollar values are in 1990 dollars. For public exposure risk, the range of SVOL estimates is from $\$ 3.7$ million to $\$ 31.7$ million with a mean of about $\$ 11$ million. If the high figure of $\$ 31.7$ million is omitted as an outlier, the range is much narrower; from $\$ 3.7$ to $\$ 4.4$ million with a mean of $\$ 4.1$ million. For worker risk, the range is from $\$ 3.1$ million to $\$ 14.3$ million with a mean of about $\$ 9$ million.

For public risk, the dollars per person-rem for a $7 \%$ discount rate range from about $\$ 1150$ per personrem to $\$ 9800$ per person-rem with a mean of approximately $\$ 3400$ per person-rem. For the 3\% discount rate, the range is from about $\$ 1500$ per person-rem to $\$ 13000$ per person-rem with a mean of about $\$ 4500$ per person-rem. If the high SVOL of $\$ 31.7$ million is omitted as an outlier, the corresponding range is from $\$ 1150$ per person-rem to $\$ 1360$ per person-rem at the $7 \%$ discount rate and from $\$ 1500$ per person-rem to $\$ 1800$ per person-rem at the $3 \%$ discount rate. 


\section{Summary of Results}

For worker risk, at a $7 \%$ discount rate the range is from $\$ 960$ per person-rem to $\$ 4300$ per person-rem with a mean of $\$ 2800$ per person-rem, and, at a $3 \%$ discount rate, from $\$ 1260$ per person-rem to $\$ 5700$ per person-rem with a mean of approximately $\$ 3700$ per person-rem.

In evaluating the latent health effects of low LET, low dose radiation exposure, the dollars per personrem values reported above are the product of the SVOL and the average BEIR V risk of $5 \times 10^{-4}$ fatalities per person-rem or $7.3 \times 10^{-4}$ cancers per person-rem (including non-fatal cancers), discounted over the latency period of cancer induction as evaluated in Chapter 3. For a $0 \%$ discount rate, that is, no discounting, the dollars per person-rem would be simply the product of SVOL and the cancer risk. Several of the WTP studies reported in Chapter 3 from which data on SVOL has been obtained, such as traffic or auto safety, refer to the risk of immediate or near-term death. For these studies, discounting the SVOL over the latency period to obtain dollars per person-rem is appropriate. However, for WTP studies dealing with cancer risk which have already factored in latency periods in evaluating the SVOL, no further discounting is necessary to obtain the dollar per person-rem values.

Dollars per person-rem values based on the loss of human capital approach as developed in the HECOM model have been calculated in section 3.2 of Chapter 3 for four population cohorts; 20 and 30 year old males, and 20 and 30 year old females. At a $3 \%$ discount rate, the results range from $\$ 288$ per person-rem for a 20 year old male cohort to $\$ 156$ per person-rem for a 30 year old female cohort. At a $7 \%$ discount rate, the range is from $\$ 124$ personrem for a 30 year old male cohort to $\$ 73$ per person-rem for a 30 year old female cohort. Assuming a $50 \%$ male, $50 \%$ female population in both age cohorts, the 1990 dollars per person-rem values, shown in Table 5-3, range from approximately $\$ 100$ per person-rem at a $7 \%$ discount rate for both 20 and 30 year old cohorts, and, at a
$3 \%$ discount rate, from $\$ 231$ per person-rem for the 20 year cohort and $\$ 209$ per person-rem for the 30 year cohort.

Depending on the preferred approach, these estimates can be used in safety enhancement (or, equivalently, dose avoidance) value-impact analyses where health consequences to the immediately affected persons are the only element of concern. That is, where no extensive contamination of land and/or property or agricultural land and foodstuffs is expected or possible.

In performing value-impact analyses of reactor backfits designed to prevent or mitigate the releases from reactor accidents, however, the possibility of an accident causing extensive offsite damage with its attendant costs has to be taken into account; the costs depend on the stringency and extent of the protective measures employed to protect the offsite population as analyzed above in Chapter 4 . The ratio of the offsite damage costs to the person-rem averted as a function of the long-term interdiction limit has been evaluated in sections 4.1.4 and 4.1.5 of Chapter 4 at five reactor sites in the U.S.; Grand Gulf, Peach Bottom, Sequoyah, Surry, and Zion. The optimal value of this ratio, based on the minimum of the total cost curve as a function of the interdiction limit, ranges from $\$ 2500$ per person-rem to $\$ 3500$ per person-rem with a mean of approximately $\$ 3000$ per person-rem as shown in Table 5-4.

To obtain the dollars per person-rem appropriate for reactor backfits, where both public health effects and offsite costs have to be considered, we combine the range of values for public exposure risk from Table 5-2 with the offsite costs per person-rem averted from Table 5-4. The results are displayed in Table $5-5$. For a $7 \%$ discount rate, they range from a low of $\$ 3650$ per person-rem to a high of $\$ 13300$ per person-rem with a mean of $\$ 6400$ per person-rem. For a 3\% discount rate, they range from a low of $\$ 4000$ per person-rem to a high of $\$ 16500$ per person-rem with a mean of $\$ 7500$ per person-rem. 
Finally, for the onsite costs to be used in reactor backfit analyses as offsets to the costs of implementation, a best estimate of the risk-based cost in 1990 dollars for a discount rate of $7 \%$ for a generic plant is $\$ 4.2 \mathrm{E}+10 * \mathrm{CDF}$ per year where $\mathrm{CDF}$ is the core damage frequency per year. The cost conditional on accident occurrence is $\$ 4.7 \mathrm{E}+9$.

To summarize, in the preceding sections, we have seen that estimates of the statistical value of life cover a broad range, from less than one million to more than ten million dollars. Obviously, government agencies responsible for regulating public health and safety are faced with the difficult decision of assigning a dollar value to the SVOL. Such a decision is judgmental in nature and depends on the societal perspective of the responsible authorities. The data contained in this report are meant to provide the background information needed for supporting this decision and assigning an appropriate dollar value to avoided collective dose (person-rem). 
5 Summary of Results

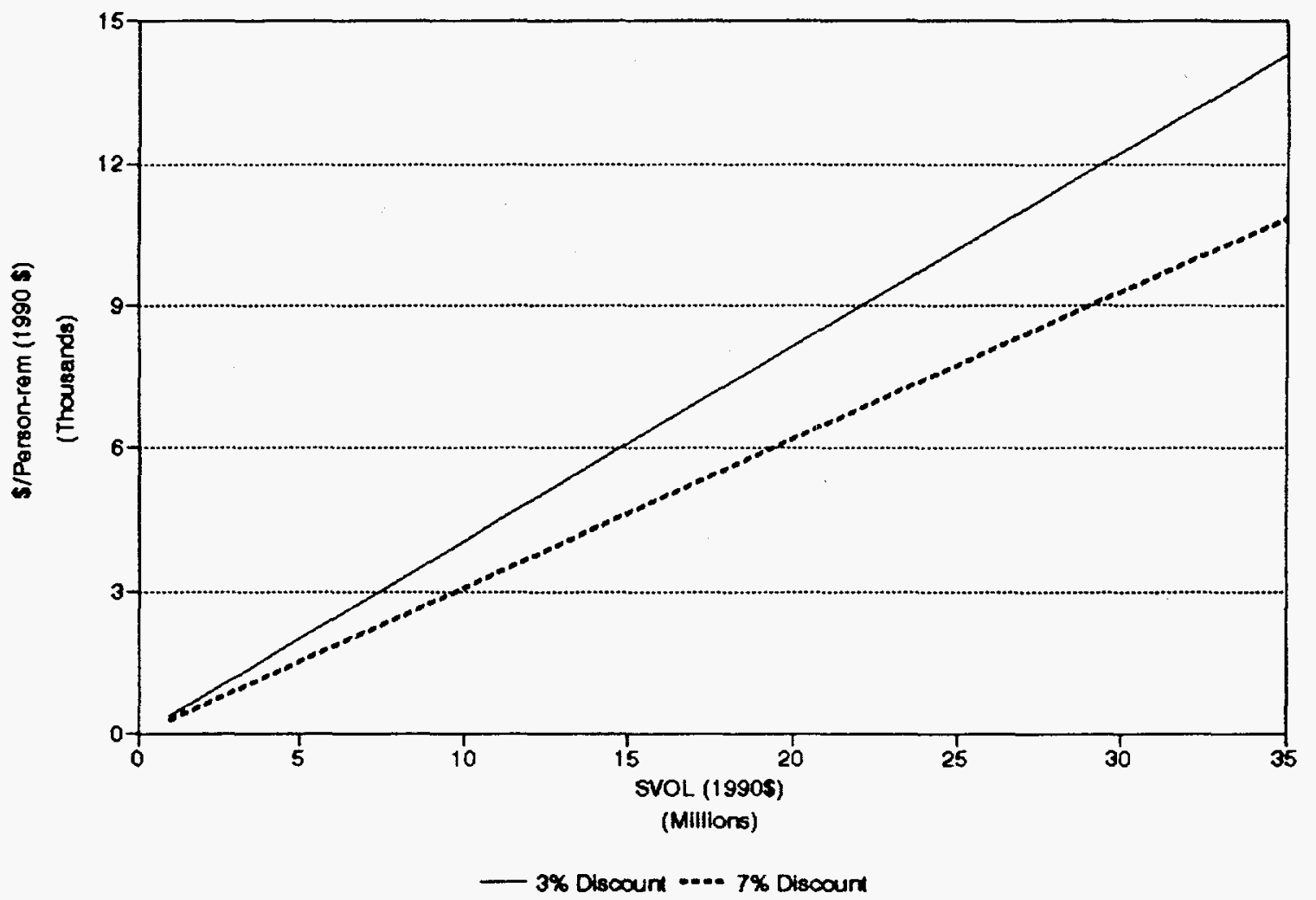

Figure 5-1 Dollars Per Person-Rem as a Function of SVOL 
5 Summary of Results

Table 5-1 Estimated Values of 1990 Dollars Per Person-Rem for Several Illustrative Values of SVOL

\begin{tabular}{||c|c|c|c|c|c|c||}
\hline \multirow{2}{*}{\begin{tabular}{c}
$*$ \\
\multirow{2}{*}{ SVIlustrative }
\end{tabular}} & \multicolumn{5}{|c|}{1990 Dollars per Person-Rem } \\
\cline { 2 - 8 } & \multicolumn{3}{|c|}{ 7\% Discount Rate } & \multicolumn{3}{c|}{ 3\% Discount Rate } \\
\cline { 2 - 8 } & $\begin{array}{c}\text { Non-Fatal } \\
\text { Cancer }\end{array}$ & $\begin{array}{c}\text { Fatal } \\
\text { Cancer }\end{array}$ & Total & $\begin{array}{c}\text { Non-Fatal } \\
\text { Cancer }\end{array}$ & $\begin{array}{c}\text { Fatal } \\
\text { Cancer }\end{array}$ & Total \\
\hline One Million Dollars & 34 & 276 & 310 & 23 & 385 & 408 \\
\hline Three Million Dollars & 103 & 826 & 929 & 67 & 1152 & 1219 \\
\hline Ten Million Dollars & 344 & 2750 & 3094 & 225 & 3835 & 4060 \\
\hline
\end{tabular}


Summary of Results

Table 5-2 Estimates of SVOL and Dollars/Person-Rem for Two Discount Rates (Based on Averages of Willingness-to-Pay Studies)

\begin{tabular}{|c|c|c|c|}
\hline & Low & High & Mean \\
\hline \multicolumn{4}{|l|}{ Public Risk } \\
\hline SVOL (Million $1990 \$$ ) & 3.7 & 32 & 11 \\
\hline $\begin{array}{l}1990 \text { Dollars/Person-Rem } \\
\text { (7\% Discount Rate) }\end{array}$ & 1150 & 9800 & 3400 \\
\hline $\begin{array}{l}1990 \text { Dollars/Person-Rem } \\
\text { (3\% Discount Rate) }\end{array}$ & 1500 & 13000 & 4500 \\
\hline \multicolumn{4}{|l|}{ Worker Risk } \\
\hline SVOL (Million 1990 \$) & 3.1 & 14 & 9 \\
\hline $\begin{array}{l}1990 \text { Dollars/Person-Rem } \\
\text { (7\% Discount Rate) }\end{array}$ & 960 & 4300 & 2800 \\
\hline $\begin{array}{l}1990 \text { Dollars/Person-Rem } \\
\text { (3\% Discount Rate) }\end{array}$ & 1260 & 5700 & 3700 \\
\hline
\end{tabular}


Table 5-3 1990 Dollars Per Person-Rem Based on HECOM Model

\begin{tabular}{|l|c|c|}
\hline \multirow{2}{*}{ Cohort } & \multicolumn{2}{|c|}{ Discount Rate } \\
\cline { 2 - 3 } & $\mathbf{7 \%}$ & $\mathbf{3} \%$ \\
\hline \hline 20 year* $^{*}$ & 100 & 231 \\
\hline 30 year* $^{*}$ & 100 & 209 \\
\hline
\end{tabular}

*Note: Composed of $50 \%$ male $-50 \%$ female population.

Table 5-4 Offsite Damage Costs Per Person-Rem Averted at Five Reactor Sites (1990 Dollars/Person-Rem)

\begin{tabular}{|l|c|}
\hline \multicolumn{1}{|c|}{ Site } & Dollars/Person-Rem Averted \\
\hline \hline Grand Gulf & 2500 \\
\hline Peach Bottom & 3300 \\
\hline Sequoyah & 3000 \\
\hline Surry & 3500 \\
\hline Zion & 3000 \\
\hline \multicolumn{2}{|c|}{ Mean } \\
\hline
\end{tabular}


5 Summary of Results

Table 5-5 Dollars Per Person-Rem for Reactor Backfits

(Based on the Sum of Health and Offsite Cost Related Values)

\begin{tabular}{||l|c|c|c|c|c|c||}
\hline \multirow{2}{*}{ Category } & \multicolumn{3}{|c|}{ Discount Rate = 7\% } & \multicolumn{3}{c|}{ Discount Rate = 3\% } \\
\cline { 2 - 7 } & Low & High & Mean & Low & High & Mean \\
\hline \hline Health-Related Dollars/Person-Rem & 1150 & 9800 & 3400 & 1500 & 13000 & 4500 \\
\hline Offsite Cost Dollars/Person-Rem & 2500 & 3500 & 3000 & 2500 & 3500 & 3000 \\
\hline Total Dollars/Person-Rem & 3650 & 13300 & 6400 & 4000 & 16500 & 7500 \\
\hline
\end{tabular}




\section{APPENDIX A CONSEQUENCES OF THE CHERNOBYL ACCIDENT*}

\section{A.1 Chernobyl as a Source of Data on Accident Consequences}

Although substantial efforts have been devoted to modeling consequences of severe reactor accidents, there has been little opportunity for validating computer codes, such as MACCS [1] and CRAC2 [2]. Severe accidents have been extremely rare and, in those few cases that have occurred, the releases of radioactive materials have been small. An exception is the 1986 Chernobyl accident, which is the only nuclear power plant accident qualifying for the extreme category: "severe accident with significant offsite consequences." Thus, Chernobyl is an obvious and unique candidate for providing data needed to validate and upgrade the models used in severe accident consequence codes.

Unfortunately, much of the detailed data about the consequences of the Chernobyl accident are not yet available. For example, detailed information is lacking about specific protective measures taken, durations of the various phases of evacuation and relocation, man-power required for various phases of the actions and costs. Note that complications originate not only in the difference of the Soviet and free market economies, but also in the completeness and consistency of the information published thus far.

A recent report by the Soviet economist, Yu. I. Koryakin [3], underscores the deficiencies in the available data and in the official estimates of the costs of accident. Nevertheless, using only officially published data, Koryakin reanalyzed the costs and obtained estimates of the economic consequences

*This review was carried out in 1991 based on data available at that time. It is provided here for background purposes and its inclusion in the Statement of Work. that are more than an order of magnitude larger than previous official estimates.

In this chapter, the data published in Koryakin's report [3] is discussed and summarized by cost categories. Where possible, uncertainties in the data are quantified.

\section{A.2 Nature of the Accident}

The most severe accident to happen at a nuclear power plant occurred at Chernobyl Unit 4 in the Soviet Union on April 26, 1986. While undergoing a low-power test, this $3200 \mathrm{MWt}$ reactor of RBMK design suffered an extreme power excursion, which destroyed the fuel and reactor and led to a large release of the core inventory to the environment. The sequence of events leading to the excursion have been reviewed extensively [4].

The Chernobyl accident is not completely relevant to hypothetical accidents in U. S. LWRs because of fundamental design differences. The Soviet RBMK reactors are graphite moderated, cooled by pressurized light water flowing through the fuel elements. Because of their size and economic considerations, the reactors are not enclosed in massive containment structures, but rather in conventional industrial type buildings. The fuel channels are vertical, and water coolant circulates through the fuel assemblies from bottom to top, the circuits being connected to manifolds at each end. A massive shielding plug is located above the reactor core and coolant manifolds. A penetration in the plug aligns with each fuel channel for refueling. The RBMKs are over moderated and, upon boiling or loss of water coolant in the fuel channel, experience an increase in reactivity. 
Appendix A Consequences of the Chernobyl Accident

The power excursion in the Chernobyl Unit 4. reactor resulted in a violent steam explosion which blew off the top shielding plug and destroyed the building above the top of the reactor. Parts of fuel assemblies and graphite fragments were ejected to the surrounding area, and the core was exposed to the atmosphere. The intense heat of the core formed a convective plume which carried gaseous and volatile materials aloft to relatively high altitudes. Being exposed to air, the graphite moderator oxidized (burned), adding exothermic heat of combustion to the fission product decay heat.

The release of radioactivity into the atmosphere continued for about ten days. Onsite emergency actions included fighting multiple fires on the roofs of surrounding buildings and use of helicopters to drop materials on the reactor core. Over a ten-day period, 5,000 tonnes of lead, sand, clay, boron, and dolomite were dropped. By day eleven, a sharp reduction in the radioactive release rate was achieved.

"Early" radiation injuries were confined to the plant operating staff and firefighting brigades. Offsite radiation levels were not excessive for several hours, apparently because most of the solid radioactive debris was confined to the site and the gaseous and vaporized materials were carried aloft by the convective plume to be dispersed over a wide area. Offsite evacuation of the public was not begun until some 36 hours after the accident.

The early stages of the Chernobyl accident differ substantially from postulated severe accidents in LWRs and, therefore, are not directly applicable to accident consequence analyses for U. S. reactors. However, data on longer term protective actions does offer the prospect of useful application to U. S. cases. These actions include evacuation and relocation of the population, decontamination and interdiction of land, and eventually delayed health effects.

\section{A.3 Source Terms: Chernobyl vs. LWRs}

Since the offsite damage is a consequence of the source term (i.e., the amounts of radionuclides released during the accident), it is useful to examine the actual amount of the release at Chernobyl, shown in Table 5-1 based on data and calculations furnished by Soviet analysts. The Chernobyl core inventory and release fractions were estimated by Soviet experts as published in the INSAG [4] summary report on the Chernobyl accident.

The INSAG, 1986 report on Chernobyl states that the core inventory shown in Table 5-1 is based on decay corrected to May 6, 1986, i.e., about 10-11 days after the initiation of the accident, and calculated as prescribed by Soviet experts.

In the Chernobyl accident, the noble gases, $\mathrm{Kr}$ and $\mathrm{Xe}$, were completely released from the core. The volatiles, iodine, cesium and tellurium suffered releases between 10 percent and 20 percent of inventory. The releases of the refractories, barium, strontium, cerium, etc. amounted to between 3-6 percent of core inventory.

\section{A.4 Soviet Estimates of Costs and Economic Losses}

In this section, we will review estimates of the costs of the Chernobyl accident which were made by the Soviet economist Koryakin [3]. As shown in Table $5-2$, Koryakin estimates that the range of total costs of all post-accident losses amounts to between 168 217 billion rubles (note that this number does not include the health care expenses). However, the monetary estimate is not easily convertible into its dollar equivalent because of the significant differences between the free market and Soviet economies. The cost data reported by Koryakin is divided into a number of categories as shown in the following subsections. 
Appendix A Consequences of the Chernobyl Accident

\section{A.4.1 Onsite Decontamination and Recovery}

After the reactor core had been covered with materials dropped from helicopters, onsite recovery efforts began. Work on the reactor building entombment and nitrogen cooling system was initialized. Decontamination of the site included manual and mechanized removal of the radioactive debris, removal of 5-10 cm layer of soil and their consequent burial in the solid waste facilities of Unit 5. The ground in the vicinity of the plant, as well as the numerous plant buildings, were sprayed with decontaminating solutions (polymers) [5]. Teams consisting of 1000 people working in 5-hour shifts were employed in these activities. Areas from 160,000 to 375,000 square feet per day were covered by these teams. Cost estimates for these recovery efforts are included in the next section.

\section{A.4.2 Offsite Evacuation and Relocation}

According to one source [6], about 116,500 people were evacuated from the $30-\mathrm{km}$ zone, including the towns of Pripyat and Chernobyl and 72 villages, and 11,655 private houses were condemned. The majority of the evacuees were resettled in the Ukraine. However, Koryakin [3] mentions a total of 200,000 persons having been permanently relocated due to the accident.

Since there is no detailed information on costs and the man-power involved in the measures undertaken onsite and in the vicinity of the plant, the total onsite costs and economic losses plus the evacuation and resettlement costs will be taken as 8.6 billion rubles following Koryakin's estimates.

\section{A.4.3 Cost of the Offsite Measures and Economic Losses}

\section{A.4.3.1 Cost of Land Interdiction}

The contaminated land is divided into two groups [3]: the land contaminated by the ${ }^{137} \mathrm{Cs}$ isotope with the level of radioactivity of more than $15 \mathrm{Ci} / \mathrm{km}^{2}$ $\left(0.555 \times 10^{6} \mathrm{~Bq} / \mathrm{m}^{2}\right)$ and the land with the level of radioactivity ranging from 5 to $15 \mathrm{Ci} / \mathrm{km}^{2}(0.185$ to $0.555 \times 10^{6} \mathrm{~Bq} / \mathrm{m}^{2}$ ). [By comparison, the ground concentration of Cs-137 on agricultural land which would trigger the $5 \mathrm{mSv}(0.5 \mathrm{rem})$ effective whole body EPA Protective Action Guide Level for a maximally exposed individual is $1.8 \mathrm{E} 6 \mathrm{~Bq} / \mathrm{m}^{2}$ or, approximately, $48 \mathrm{Ci} / \mathrm{km}^{2}$.] The size of the land in the first category is estimated to be $10.5 \times 10^{3} \mathrm{~km}^{2}$ $\left(2.595 \times 10^{6}\right.$ acres $)$, while the size of the land in the second category is approximately $21.0 \times 10^{3} \mathrm{~km}^{2}$ $\left(5.189 \times 10^{6}\right.$ acres $)$. According to Koryakin, the error in estimates can be as high as $20-25$ percent. (Note that the Chairman of the Special Commission on Liquidation of Consequences of Accidents and Natural Disasters [7] reported that the total amount of contaminated land in Ukraine was about $50 \times 10^{3} \mathrm{~km}^{2}\left(12.355 \times 10^{6}\right.$ acres $)$.)

Assuming that all the contaminated land is interdicted for food production and that the cost of bringing up one hectare ( 2.47 acres) of land into agricultural production as a replacement is 30 thousand rubles (this is a low estimate: the cost in this region varies from 20 to 120 thousand rubles per hectare), Koryakin derived a cultivated land replacement cost of 94.5 billion rubles. Koryakin also provided a lower estimate of 57.5 billion rubles by suggesting that the part of the land with a lower contamination can be used for agricultural activities; however, the value of 94.5 billion rubles was recommended as a more realistic cost.

\section{A.4.3.2 Cost of Mitigative Measures}

In addition to the costs discussed in Section 5.4.1, Koryakin quotes $25-35$ billion rubles which are projected to be spent on mitigative measures predominantly in Ukraine, Byelorussia, and Russia till the year 2000 without description of specific measures. Note that these expenses do not include the cost of the lost productivity by the hundreds of thousands of people who had to be relocated from the contaminated areas. 
Appendix A Consequences of the Chernobyl Accident

Some additional information on the measures taken to deal with the health consequences of the Chernobyl release are provided in articles by Sergeev [8], Kondrusev [9], Il'in [10], and Romanenko [11]. However, no information on the costs of these measures is provided by the authors.

\section{A.4.3.3 Loss of Capital Investment in Nuclear Power Plants}

According to Koryakin, a total of 31 power plants with an electric output of $30.38 \mathrm{GW}$ at different stages of design, construction, and operation have been affected by the Chernobyl accident (including the Chernobyl Unit 4) (Table 5-3). The total loss in capital investment is estimated as 5 billion rubles. This value is based on a construction cost of 400 to 500 rubles per $1 \mathrm{~kW}$; it also includes the cost of manufactured equipment which was not installed.

\section{A.4.3.4 Cost of Energy Under-Production and Delay of Supply}

Losses due to under-production of electric energy by the Chernobyl Unit 4 and Armenia Units $1 \& 2$ are calculated over six years following the accident with an assumption of a twenty-fold increase of the national product on a unit investment in power generation. With the under-production of approximately $100 \mathrm{GW}-\mathrm{h}$ and the electric energy cost of 0.015 ruble $/ \mathrm{kW}-\mathrm{h}$, the losses amount to 30 billion rubles.

The estimates of the economic losses due to delays in providing the industry with electric energy are based on an assumption that a one-year delay of 1 GW reduces the national product by 1 billion rubles (this is an optimistic value; the original value of 2 billion rubles is given by Styrikovich [12]). The delays in the present context are produced by freezing and canceling construction of nuclear power plants. The delay is taken as three years. There- fore, the delay in providing $12 \mathrm{GW}-\mathrm{h}$ of electric power will result in a loss of 36 billion rubles.

In addition, modifications to the fuel design for the RBMK reactors will increase the average cost of electric power by approximately 6 percent. Over the period till the year 2000, this will cost about 1 billion rubles.

\section{A.4.3.5 Cost of Safety Upgrades at Nuclear Power Plants}

Various safety upgrades for the RBMK-type reactors are being considered currently in the Soviet Union. The major issues are reinforcement of steam generators supports and reactor building. The plans also include equipping the operating VVER-440 (V230) reactors with the Emergency Core Cooling System. The approximate cost of these upgrades amounts to 4.5 billion rubles.

\section{A.4.3.6 Other Costs}

No specific information is available relating to the costs of the condemned real estate property, the costs of the destroyed foodstuffs, and the costs of insurance and the health care provided to the workers and affected population.

\section{A.4.4 Estimation of Total Costs and Economic Losses}

Based on the data provided above, the total cost of the accident to the Soviet Union (including the economic losses) is estimated to be:

$$
\begin{aligned}
& 8.6+94.5+30.0+5.0+30.0+36.0+1.0+ \\
& 4.5=209.6 \text { billion rubles. } \\
& \text { with a range from } 168 \text { to } 217 \text { billion rubles (Table } \\
& \text { A-2). }
\end{aligned}
$$

Of these costs, about 125 billion rubles is what would be normally considered an offsite cost in the $\mathrm{U}$. S.; the remainder is the onsite cost and the cost 
Appendix A Consequences of the Chernobyl Accident

to the Soviet nuclear industry for design changes and modifications to the fleet of Soviet nuclear power plants.

\section{A.5 Dose Commitment and Estimate of Latent Health Effects}

The United Nations Scientific Committee on the Effects of Atomic Radiation (UNSCEAR) has estimated the effective dose equivalent commitment for all of the countries in the Northern Hemisphere [13]. For the Soviet Union, the UNSCEAR estimate for the collective effective dose equivalent commitment is 226,000 person-Sv $(2.26 \mathrm{E}+7$ personrem).

Estimates of doses to 135,000 persons [4] residing within $30 \mathrm{~km}$ of Chernobyl who were reported to have been evacuated following the accident were provided in the INSAG Report [4] and have been summarized in a report issued by the $U$. S. Department of Energy [14] on the health and environmental consequences of the Chernobyl accident. The collective dose equivalent to the evacuated population was estimated at 16,000 person-Sv (1.6E +6 person-rem) for an average dose equivalent of $120 \mathrm{mSv} /$ person (12 rem/person). Approximately, 24,000 persons residing within 3-15 $\mathrm{km}$ of Chernobyl were estimated to have received an average dose equivalent of $450 \mathrm{mSv} /$ person (45 $\mathrm{rem} /$ person). Another 65,000 people residing between $15 \mathrm{~km}$ and $30 \mathrm{~km}$ from Chernobyl received $53 \mathrm{mSv} /$ person (5.3 rem/person), while the 45,000 residents of Pripyat, who lived within $3 \mathrm{~km}$ of Chernobyl, received $33 \mathrm{mSv} /$ person ( $3.3 \mathrm{rem} /$ person).

\section{A.6 U. S. Equivalent Cost of a Chernobyl Release}

To convert Koryakin's estimate of 210 billion rubles into comparable U. S. figures, we note that the conversion of U. S. dollars into Soviet rubles at this time is highly uncertain (the variation between the "official" rate of 1 ruble $=\$ 1.65$ and the "open market" rate of around $10^{\dagger}$ or more rubles $=\$ 1.00$ is perhaps a factor of 20 or more). More importantly, sectoral conversion rates (e.g., for estimating the value of the loss of agricultural or urban property) are even more difficult to define given the differences in economic systems.

However, a very approximate equivalent $U$. S. offsite cost of the Chernobyl release may be derived from the data on relocated persons and interdicted farms and nonfarm areas contained in Koryakin's report and applying $U$. S. unit values to the relevant sectors. We consider the total offsite costs as arising from just three factors: (1) costs of permanent condemnation of the same area of farmland as mentioned in the Koryakin study, (2) costs of permanent relocation of the affected population, estimated by Koryakin at 200,000 persons, and (3) costs of permanent condemnation of nonfarm property. For simplicity, we do not include decontamination costs, on the assumption that all interdicted areas are permanently condemned and not returned to habitability or production.

In the MACCS code, the unit cost of condemning nonfarm property is calculated on a per person basis as the sum of (a) the cost to permanently relocate an individual and (b) the per person value of nonfarm wealth for the region. The unit cost is multiplied by the total number of persons permanently relocated to provide the total costs of relocation and nonfarm property losses. The unit cost of condemning farm property is taken to be the unit value of farm wealth for the region. The MACCS input data files contain state-level estimates of the per person value of nonfarm wealth and the per hectare value of farm wealth based on data derived from the U. S. Statistical Abstracts.

\footnotetext{
${ }^{\dagger}$ This rate was in effect in 1991 when the chapter was written. The current rate is approximately 3000 rubles $=\$ 1.00$.
} 
Appendix A Consequences of the Chernobyl Accident

Farm wealth on a state basis varies from a high of $\$ 6500 /$ ha to a low of approximately $\$ 500 / \mathrm{ha}$, depending on the productivity of the land, the value of installed machinery and equipment, the type of farming, etc. Since the Chernobyl site is located in an area of good agricultural productivity according to Koryakin's study, a value closer to the higher end of the U. S. state-level figures seem appropriate. Accordingly, we assume $\$ 4000 / \mathrm{ha}$ as the value of farmwealth. Koryakin's report [3] divides the total area of contaminated farmland into two categories, depending on the level of contamination. The first category with an area of about 2.6 million acres (1.05 million ha) is assumed to be permanently interdicted; the second category with an area of 5.2 million acres ( 2.1 million ha) may be returned to agricultural production eventually. Thus, depending on whether the second category of land is assumed to be permanently interdicted or not, the losses of farmwealth may be estimated to range from a high of:

$$
3.15 \times 10^{6} \text { ha } \times \$ 4000 / \text { ha }=\$ 12.6 \times 10^{9}
$$

to a low of

$$
1.05 \times 10^{6} \text { ha } \times \$ 4000 / \mathrm{ha}=\$ 4.2 \times 10^{9}
$$

The per person nonfarm wealth in the U. S. on a state-level basis varies from a high of $\$ 107,000$ to a low of $\$ 60,000$ per person. For our purposes, an average of $\$ 80,000$ per person can be assumed. The population relocation cost suggested in the MACCS data input file is $\$ 5000$ per person based on the cost of alternative housing, moving, and lost income for a limited period. Based on a permanent relocation of 200,000 persons, the relocation and nonfarm property costs are:

$$
\begin{aligned}
& 200,000 \text { persons } \times \$(5000+80000) / \text { person } \\
& =\$ 17 \times 10^{9}
\end{aligned}
$$

The total offsite cost estimated in this very approximate way ranges from a high of $12.6+17=$ 29.6 billion dollars, to a low of $4.2+17=21.2$ billion dollars.

Note that this estimate does not include the costs of emergency evacuation or the destruction of foodstuffs or decontamination efforts. In most sitespecific consequence calculations, evacuation and crop disposal costs are usually a small fraction of the total for severe releases. Decontamination costs have been excluded due to the assumption of permanent interdiction of affected land and property. (However, in most realistic situations, there will probably be decontamination efforts in areas around the site for which costs will be incurred.) Health care costs for monitoring as well as treating latent cancers for the affected population are also not included in this range of $\$ 30$ billion to $\$ 21$ billion for the offsite costs. While these estimates are very approximate, they are indicative of the range of severe accident costs established in detailed, site-specific studies.

\section{A.7 Conclusions Concerning the Application of Chernobyl Data to U. S. Severe Accident Consequence Analyses}

The data on costs of the Chernobyl accident hold promise of considerable value to U. S. backfit analyses, if the information is further exploited. Information on manpower used for decontamination, monitoring, planning, and other direct labor devoted to recovery efforts could be converted into U. S. terms. As seen in Section 5.6, land condemnation and population relocation costs can be translated into specific situations in the U. S.

It would appear that a larger analytical effort than was possible here would be of great value to the evaluation of accident consequences.

\section{A.8 References}

1. D. E. Chanin, et al., 1989, "MELCOR Accident Consequences Code System (MACCS) Vol. 1, User's Guide," NUREG/CR-4691, SAND-861562, Sandia National Laboratories, Albuquerque, NM, 1989. 
Appendix A Consequences of the Chernobyl Accident

2. L. T. Ritchie, et al., 1985, "Calculations of Reactor Accident Consequences, Version 2, CRAC2: Computer Code User's Guide," NUREG/CR-4185, SAND-85-0283, Sandia National Laboratories, Albuquerque, NM, 1985.

3. Yu. I. Koryakin, "Assessment of Economic Losses Caused by the Chernobyl Accident," Second Draft, Moscow, February 8, 1990 (Translated from Russian by N. K. Meshkov, ANL).

4. IAEA, International Nuclear Safety Advisory Group, "Summary Report on the Post-Accident Review Meeting on the Chernobyl Accident," Safety Series No. 75-INSAG-1, IAEA, Vienna, 1986.

5. U.S. Nuclear Regulatory Commission, "Report on the Accident at the Chernobyl Nuclear Power Station," NUREG-1250, 1987.

6. N. I. Omel'yanets, et al., "Medical Demographic Consequences of the Chernobyl Accident," Proceedings of the All-Union Conference Organized by the USSR Ministry of Health and the All-Union Scientific Centre of Radiation Medicine, USSR Academy of Medical Sciences, Kiev, May 11-13, 1988, pp. 315-325.

7. K. Masik, Soviet Newspaper: "Pravda Ukrainy," January 18, 1990.

8. G. V. Sergeev, "Medical and Sanitary Measures Taken to Deal with the Consequences of the Chernobyl Accident," Medical Aspects of the Chernobyl Accident, Proceedings of the AllUnion Conference Organized by the USSR Ministry of Health and the All-Union Scientific Centre of Radiation Medicine, USSR Academy of Medical Sciences, Kiev, May 11-13, 1988, pp. 23-38.
9. A. I. Kondrusev, "Sanitary and Health Measures Taken to Deal with the Consequences of the Chernobyl Accident," Medical Aspects of the Chernobyl Accident, Proceedings of the All-Union Conference Organized by the USSR Ministry of Health and the AllUnion Scientific Centre of Radiation Medicine, USSR Academy of Medical Sciences, Kiev, May 11-13, 1988, pp. 39-45.

10. L. A. Il'in, "The Chernobyl Experience in the Context of Contemporary Radiation Protection Problems," Medical Aspects of the Chernobyl Accident, Proceedings of the All-Union Conference Organized by the USSR Ministry of Health and the All-Union Scientific Centre of Radiation Medicine, USSR Academy of Medical Sciences, Kiev, May 11-13, 1988, pp. 47-63.

11. A. E. Romanenko, "Protection of Health During a Large Scale Accident," Medical Aspects of the Chernobyl Accident, Proceedings of the All-Union Conference Organized by the USSR Ministry of Health and the AllUnion Scientific Centre of Radiation Medicine, USSR Academy of Medical Sciences, Kiev, May 11-13, 1988, pp. 65-78.

12. M. A. Styrikovich and A. A. Beschinsky, "Problems and Directions of Development of Power Industry as a Part of the Fuel-Energy Complex," Book: "Contemporary Problems of Power Industry,” Energoatomizdat, 1984.

13. United Nations Scientific Committee on the Effects of Atomic Radiation (UNSCEAR), "Sources, Effects, and Risks of Ionizing Radiation," United Nations, New York, 1988.

14. U. S. Department of Energy, "Health and Environmental Consequences of the Chernobyl Nuclear Power Plant Accident," DOE/ER-0332, Washington, DC, June 1987. 
Appendix A Consequences of the Chernobyl Accident

Table A-1 Chernobyl Release of Core Inventory

\begin{tabular}{|c|c|c|}
\hline \multirow{2}{*}{ Isotope } & \multicolumn{2}{|c|}{ Chernobyl $^{1}$} \\
\hline & Inventory $(\mathrm{Bq})$ & Release Fraction (\%) \\
\hline $\mathrm{Kr}-85$ & 3.3E16 & 100 \\
\hline $\mathrm{Xe}-133$ & 1.7E18 & 100 \\
\hline I-131 & 1.3E18 & 20 \\
\hline Te-132 & $3.2 \mathrm{E} 17$ & 15 \\
\hline Cs-134 & $1.9 \mathrm{E} 17$ & 10 \\
\hline Cs-137 & 2.9E17 & 13 \\
\hline Mo-99 & 4.8E18 & 2.3 \\
\hline $\mathrm{Zr}-95$ & 4.4E18 & 3.2 \\
\hline Ru-103 & 4.1E18 & 2.9 \\
\hline $\mathrm{Ru}-106$ & 2.0E18 & 2.9 \\
\hline $\mathrm{Ba}-140$ & 2.9E18 & 5.6 \\
\hline $\mathrm{Ce}-141$ & 4.4E18 & 2.3 \\
\hline Ce-144 & 3.2E18 & 2.8 \\
\hline Sr-89 & $2.0 \mathrm{E} 18$ & 4.0 \\
\hline Sr-90 & $2.0 \mathrm{E} 17$ & 4.0 \\
\hline Np-239 & 1.4E17 & 3.0 \\
\hline Pu-238 & $1.0 \mathrm{E} 15$ & 3.0 \\
\hline Pu-239 & $8.5 \mathrm{E} 14$ & 3.0 \\
\hline $\mathrm{Pu}-240$ & $1.2 \mathrm{E} 15$ & 3.0 \\
\hline $\mathrm{Pu}-241$ & 1.7E17 & 3.0 \\
\hline $\mathrm{Cm}-242$ & $2.6 \mathrm{E} 16$ & 3.0 \\
\hline
\end{tabular}

$3.3 \mathrm{E} 16=3.3 \times 10^{16}$

${ }^{1}$ Chernobyl inventory and release fractions from INSAG report on Chernobyl. 
Table A-2 Summary of Losses and Costs from the Chernobyl Accident

(Koryakin, 1990)

\begin{tabular}{|c|c|c|c|c|}
\hline \multirow[t]{2}{*}{ Type } & \multirow{2}{*}{$\frac{\text { Losses and Costs }}{\text { Description }}$} & \multicolumn{2}{|c|}{$\begin{array}{c}\text { Amount } \\
\text { (billion rubles) }\end{array}$} & \multirow[t]{2}{*}{ NOTES } \\
\hline & & Minimum & Maximum & \\
\hline I & Lost productivity of the land & 57.0 & 94.5 & Not including possible losses of certain water resources \\
\hline II & $\begin{array}{l}\text { Direct costs of labor to mitigate the consequences } \\
\text { of the accident }\end{array}$ & 35.0 & 45.0 & $\begin{array}{l}\text { Not including losses caused by excluding from productive work } \\
\text { hundreds of thousands people displaced from the contaminated } \\
\text { zones and either forced to interrupt their professional work or not } \\
\text { working at all because of the accident. }\end{array}$ \\
\hline III & $\begin{array}{l}\text { Loss of invested capital caused by discontinued } \\
\text { operation or construction of nuclear power stations }\end{array}$ & 5.0 & 5.0 & Including equipment that was fabricated but not used. \\
\hline \multirow[t]{5}{*}{ IV } & $\begin{array}{l}\text { Losses due to interruptions in the supply of } \\
\text { electricity, unrealized production of electricity, and } \\
\text { changes in economic conditions for its production } \\
\text { in active nuclear power stations }\end{array}$ & & & $\begin{array}{l}\text { Excluding losses due to interrupted or unrealized production in } \\
\text { industrial manufacturing establishments located in the evacuated } \\
\text { zones. }\end{array}$ \\
\hline & a. Interrupted supply of electricity & 30.0 & 30.0 & \\
\hline & b. Lost electricity production & 36.0 & 36.0 & \\
\hline & $\begin{array}{l}\text { c. Change in economic conditions for producing } \\
\text { electricity in nuclear power stations }\end{array}$ & $\underline{0.85}$ & $\underline{0.85}$ & \\
\hline & Subtotal of Type IV losses & 66.8 & 66.8 & \\
\hline $\mathrm{v}$ & $\begin{array}{l}\text { Additional capital costs to increase the safety of } \\
\text { existing nuclear power stations }\end{array}$ & 3.9 & 5.1 & $\begin{array}{l}\text { Expenses only probable because of uncertainty that they will occur in } \\
\text { the RBMK power plants; in particular, losses not included because of } \\
\text { interrupted power supply while power plant is being reconstructed. }\end{array}$ \\
\hline \multirow[t]{2}{*}{ VI } & Other costs & 0.6 & 0.6 & \\
\hline & TOTAL & 168.0 & 217.0 & \\
\hline
\end{tabular}


Appendix A Consequences of the Chernobyl Accident

Table A-3 Nuclear Power Reactors Affected by Chernobyl Accident in USSR

\begin{tabular}{||l|c|c|c|c|c|c||}
\hline Reactor & $\begin{array}{c}\text { Power } \\
\text { (MWt) }\end{array}$ & $\begin{array}{c}\text { Shut } \\
\text { Down } \\
\text { (Lost) }\end{array}$ & $\begin{array}{c}\text { Construction } \\
\text { Suspended }\end{array}$ & $\begin{array}{c}\text { Reduced } \\
\text { Funding for } \\
\text { Construction }\end{array}$ & $\begin{array}{c}\text { Construction } \\
\text { Stopped }\end{array}$ & $\begin{array}{c}\text { Project } \\
\text { Cancelled }\end{array}$ \\
\hline \hline RBMK-1000 & 1000 & $(1)$ & 2 & 1 & 2 & \\
\hline RBMK-1500 & 1500 & & 1 & & & \\
\hline VVER-440 & 440 & 2 & & & & \\
\hline VVER-1000 & 1000 & & 2 & & 7 & 13 \\
\hline
\end{tabular}




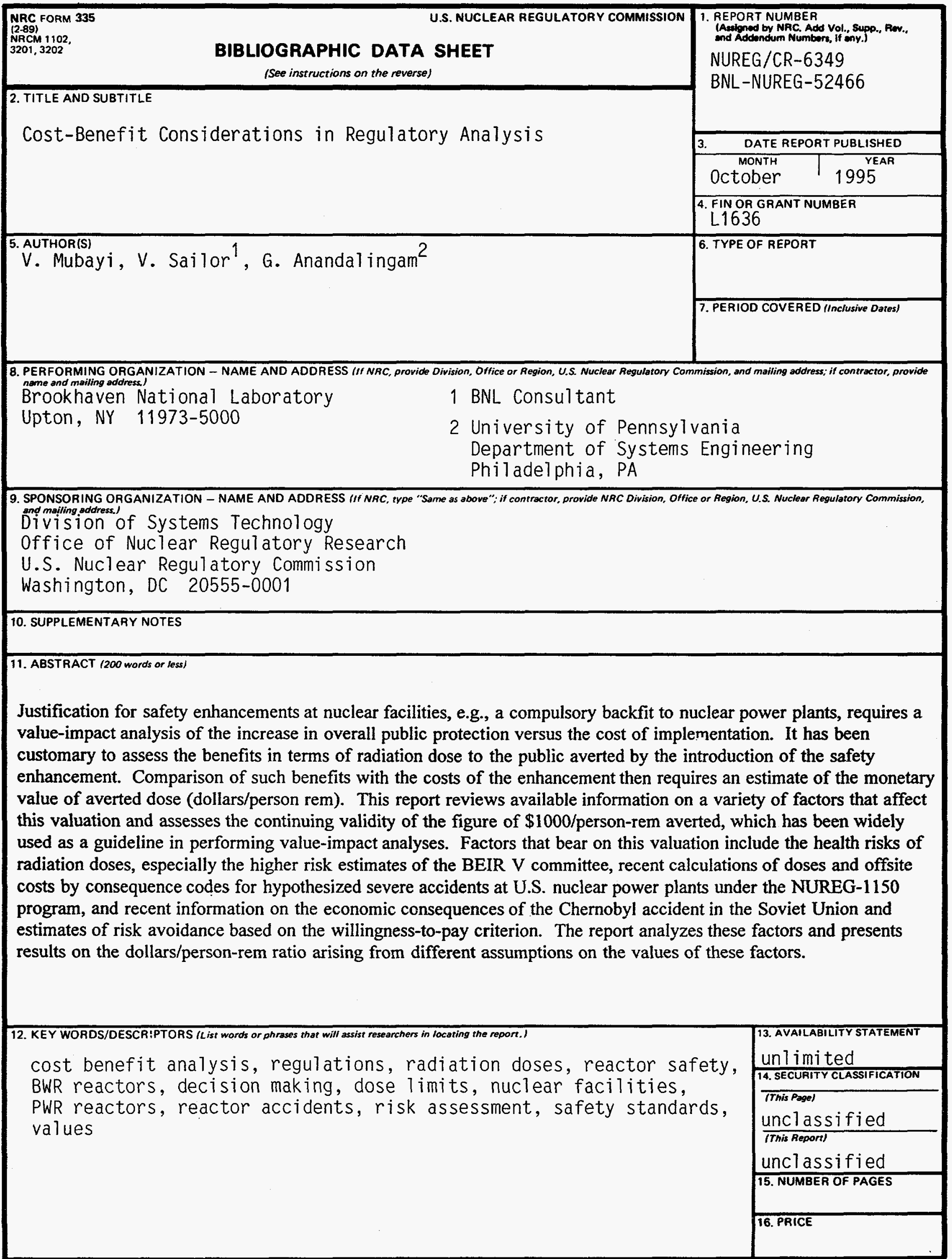

